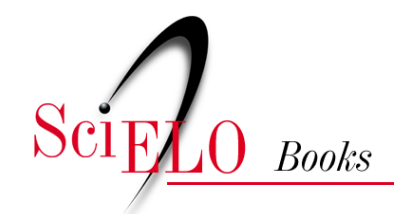

\title{
Estudos territoriais no Brasil e na Costa Rica
}

\author{
Glaucio José Marafon \\ Lilliam Quirós Arias \\ Meylin Alvarado Sánchez \\ (orgs.)
}

MARAFON, G.J., ARIAS, L.Q., and SÁNCHEZ, M.A., orgs. Estudos territoriais no Brasil e na Costa Rica (online). Rio de Janeiro: EDUERJ, 2018, 332 p. ISBN 978-85-7511-499-5. Available from: doi: $10.7476 / 9788575114995$. Also available in ePUB from:

http://books.scielo.org/id/j3jbg/epub/marafon-9788575114995.epub.

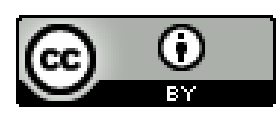

All the contents of this work, except where otherwise noted, is licensed under a Creative Commons Attribution 4.0 International license.

Todo o conteúdo deste trabalho, exceto quando houver ressalva, é publicado sob a licença Creative Commons Atribição 4.0.

Todo el contenido de esta obra, excepto donde se indique lo contrario, está bajo licencia de la licencia $\underline{\text { Creative Commons }}$ $\underline{\text { Reconocimento } 4.0 .}$. 


\section{Estudos Territoriais no Brasil e na Costa Rica}


UNIVERSIDADE DO ESTADO DO RIO DE JANEIRO

Reitor

Ruy Garcia Marques

Vice-reitora

Maria Georgina Muniz Washington

EDITORA DA UNIVERSIDADE DO ESTADO DO RIO DE JANEIRO

uer

\author{
Conselho Editorial \\ Glaucio José Marafon (presidente) \\ Henriqueta do Coutto Prado Valladares \\ Hilda Maria Montes Ribeiro de Souza \\ Italo Moriconi Junior \\ José Ricardo Ferreira Cunha \\ Lucia Maria Bastos Pereira das Neves \\ Luciano Rodrigues Ornelas de Lima \\ Maria Cristina Cardoso Ribas \\ Tania Maria Tavares Bessone da Cruz Ferreira \\ Aníbal Francisco Alves Bragança (UFF) \\ Katia Regina Cervantes Dias (UFRJ)
}




\author{
Organização \\ Glaucio José Marafon \\ Lilliam Quirós Arias \\ Meylin Alvarado Sánchez
}

\title{
Estudos Territoriais no Brasil e na Costa Rica
}

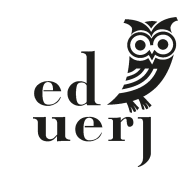

Rio de Janeiro 2018 
Copyright @ 2018 , EdUERJ.

Todos os direitos desta edição reservados à Editora da Universidade do Estado do Rio de Janeiro. É proibida a duplicação ou reprodução deste volume, ou de parte do mesmo, em quaisquer meios, sem autorização expressa da editora.

Editora da UNIVERSIDADE DO ESTADO DO RIO DE JANEIRO

Rua São Francisco Xavier, 524 - Maracanã

CEP 20550-013 - Rio de Janeiro - RJ - Brasil

Tel./Fax.: 55 (21) 2334-0720 / 2334-0721

www.eduerj.uerj.br

eduerj@uerj.br

\author{
Editor Executivo \\ Coordenadora Administrativa \\ Coordenadora Editorial \\ Assistente Editorial \\ Coordenador de Produção \\ Supervisor de Revisão \\ Revisão \\ Capa \\ Projeto e Diagramação
}

\author{
Glaucio Marafon \\ Elisete Cantuária \\ Silvia Nóbrega \\ Thiago Braz \\ Mauro Siqueira \\ Elmar Aquino \\ Elmar Aquino \\ Érika Neuschwang \\ Júlio Nogueira \\ Thiago Netto
}

E82 Estudos territoriais no Brasil e na Costa Rica / Glaucio José Marafon, Lilliam Quirós Arias, Meylin Alvarado Sánchez, organizadores. - Rio de Janeiro : EdUERJ, 2018. $336 \mathrm{p}$.

ISBN 978-85-7511-473-5

1. Geografia - Brasil - Costa Rica. I. Marafon, Glaucio José. II. Quirós Arias, Lilliam. III. Alvarado Sánchez, Meylin.

CDU 911.5/.9(81)(728.6)

Bibliotecária: Leila Andrade CRB7/4016 


\section{Sumário}

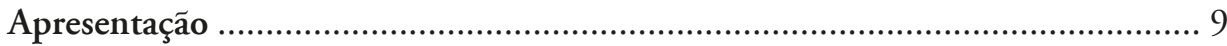

\section{Parte I - Estudos Territoriais no Brasil}

1. Consideraçóes sobre as Categorias analíticas do espaço geográfico em Milton Santos.... 23

Monica Sampaio Machado e Thiago Adriano Machado

2. O setor sucroenergético no Brasil: efeitos e contradições 41 Patrícia Francisca de Matos e Glaucio José Marafon

3. Na trilha das reservas particulares do patrimônio natural (RPPN): novas interfaces paisagísticas?

Elton Simôes Gonçalves e Glaucio José Marafon

4. Turismo rural: resgatando conceitos e atualizando reflexóes 91

Glaucio José Marafon e Valéria Maria de Souza Lima

5. A dimensão espacial da atividade turística no território fluminense 113 Nathan da Silva Nunes e Miguel Angelo Ribeiro

6. Ser "carioca" / ser "fluminense": la creación de identidades por las fronteras politico-administrativas en el espacio sudamericano Augusto César Pinheiro da Silva 


\section{Parte II - Estudos Territoriais na Costa Rica}

7. Políticas públicas habitacionales: la vivienda social en Costa Rica 163

Lilliam Quirós Arias

8. Planes de sostenibilidad turística para el turismo rural comunitario de Costa Rica: Metodología para su Elaboración

Meylin Alvarado Sánchez e Pablo Miranda Álvarez

9. Geografía de las juventudes: corporeidad y espacialidad urbana

Iliana Araya Ramírez

10. El ordenamiento del territorio y los procesos en la elaboración de planes reguladores en Costa Rica.

Lidia Orias Arguedas

11. Modelos de zonificación urbana y su implementación en Costa Rica. 261

Omar E. Barrantes Sotela

12. Esbozo con perspectiva geográfica de los estudios sobre la ciudad, el espacio y las cuestiones urbano-regionales en América Latina. 289

Omar Arrieta Chavarría

Sobre os autores 
A universidade, aliás, é, talvez, a única instituição que pode sobreviver apenas se aceitar críticas, de dentro dela própria, de uma ou outra forma. Se a universidade pede aos seus participantes que calem, ela está se condenando ao silêncio, isto é, à morte, pois seu destino é falar. A fidelidade reclamada não pode ser à universidade, e a ela não temos razão para ser fiéis. Nossa única fidelidade é com a ideia de universidade. E é a partir da ideia sempre renovada de universidade que julgamos as universidades concretas e sugerimos mudanças.

Milton Santos, 1997 


\section{Apresentação}

O presente livro é fruto da cooperação entre o Instituto de Geografia/ PPGEO da Universidade do Estado do Rio de Janeiro (UERJ) e da escola de Ciências Geográficas da Universidade Nacional da Costa Rica (UNA). Essa parceria teve início em 2011, e nesses anos tivemos uma profícua colaboração por meio de visitas técnicas, participação em eventos, publicações em periódicos, além do ingresso de alunos da Costa Rica no Programa de Pós-Graduação em Geografia, para a realização de mestrado e doutorado. Destarte, dando continuidade a essa profícua cooperação, estamos apresentando à comunidade geográfica o presente livro denominado Estudos territoriais no Brasil e na Costa Rica, que contém artigos de profissionais das duas universidades - UERJ e UNA -, com resultados de investigações e que revelam um pouco das pesquisas que estão sendo efetuadas nessas instituições.

O livro está estruturado em duas partes, com artigos do Brasil e da Costa Rica. Optamos por deixar os textos, na língua original de cada autor para que possamos nos aproximar cada vez mais e realizar mais trabalhos de forma conjunta, buscando uma maior integração entre nossos países, não sendo a língua um obtáculo.

$\mathrm{Na}$ primeira parte, "Estudos territoriais no Brasil", os autores Monica Sampaio Machado e Thiago Adriano Machado, no capítulo "Considerações sobre as categorias analíticas do espaço geográfico em Milton Santos”, apresentam a trajetória desse intelectual, que pode ser compreendida a partir de dois projetos por ele desenvolvidos: o primeiro era de produzir uma teoria geográfica. Os autores objetivam discutir alguns aspectos da sua teoria geográfica, destacando as categorias analíticas do espaço por ele desenvolvidas. É, então, tecida uma breve periodização da trajetória de Milton Santos, que distingue três principais momentos, por meio dos quais efetiva a sua produção teórica a partir de aproximações sucessivas da relação entre o espaço geográfico e o fenômeno técnico. Isso ocorre, porém, com uma renovada crítica à tradição geográfica, inclusive àquela em que o autor situa seus primeiros trabalhos. Machado e Machado identificam uma primeira fase entre 1948 e 1960, caracterizada pelos seus estudos sobre a Bahia, nos quais predominava a geografia regional de matriz lablachiana, sucedida pelo período do exílio entre 1965 e 1987, em que 
operacionaliza os conceitos marxistas para o estudo da urbanização dos países subdesenvolvidos, e, por fim, uma última fase, entre 1988 e 2001, em que sua teoria geográfica atinge a maturidade em profundo diálogo com a temática da globalização.

Para tanto, Milton Santos (1996) propõe pensar a geografia, inserida no quadro mais amplo das ciências da sociedade, a partir da consolidação e delimitação de seu objeto de estudo, o espaço geográfico, elevando-o a ente analítico independente dentro do conjunto das ciências sociais e de extremo valor para a análise e compreensão da sociedade. E, para que o espaço geográfico possa aspirar a ser esse ente analítico, independente e indispensável, é fundamental que "os conceitos e instrumentos de análise apareçam dotados de condições de coerência e operacionalidade" (Santos, 1996, p. 18). Essa tarefa, apesar de estar explícita em A natureza do espaço, foi sendo elaborada ao longo de décadas de trabalho do autor, que remontam aos finais dos anos de 1940, a partir do exercício dialético e cumulativo, característico da sua forma de produção de conhecimento.

Sempre pautado na crítica de estudos anteriores que realizava, Milton Santos incorporava novas leituras e observações do mundo empírico que permitiam dar um passo à frente ao tema investigado e, aos poucos, construía sua teoria geográfica. Dessa forma, os autores problematizam a formação de suas categorias analíticas, iniciada com a discussão sobre a Geografia como viúva do espaço, ideia apresentada em Por uma Geografia nova (1978), a provocação do autor para ressaltar a crise da Geografia na década de 1970 e a necessidade de pensá-la a partir do seu objeto, o espaço geográfico, como um produto social. Em seguida, buscando discutir e contextualizar essas categorias analíticas na teoria geográfica do autor, será assinalada a centralidade da técnica e sua incorporação ao território nos estudos por ele realizados.

No capítulo "O setor sucroenergético no Brasil: efeitos e contradições", os autores Matos e Marafon abordam como o Brasil tornou-se, há quase duas décadas, um importante produtor e consumidor de biocombustíveis como alternativa energética, com destaque para o etanol, produzido a partir da cana-de-açúcar. A necessidade de substituição dos combustíveis fósseis por “combustíveis mais limpos” conferiu uma posição de destaque ao etanol brasileiro. Com o mercado promissor, o Brasil tem visto um crescimento das monoculturas de cana-de-açúcar para abastecer o setor sucroenergético para produção de açúcar, álcool anidro (aditivo para gasolina), álcool hidratado e cogeração de energia 
(produzida pelo bagaço da cana). Os referidos autores enfatizam que, no início do século XXI, ocorreu uma expansão acelerada do cultivo da cana no território brasileiro devido ao projeto dos biocombustíveis, que a colocou como principal opção na produção de álcool, criando novas paisagens e formas de produção, além de modificar os usos do território, especialmente de oito estados brasileiros. Eles ainda exemplificam esse processo a partir do avanço do setor sucroenergético no estado de Minas Gerais, especificamente no Triângulo Mineiro/Alto Paranaíba. Esse estado, no contexto da política de incentivos por parte do governo federal para expansão da produção dos biocombustíveis, teve um aumento significativo no volume produzido a partir de 2000. Cerca de $9 \%$ das 78 milhões de toneladas no Brasil, em 2016, foram produzidas em Minas Gerais, e destes, 6\% foram produzidas no Triângulo Mineiro/Alto Paranaíba. Desse modo, o texto apresenta uma reflexão do setor sucroenergético no Brasil, e em Minas Gerais, com atenção especial para as formas de acesso à cana-açúcar.

No capítulo "Na trilha das reservas particulares do patrimônio natural (RPPN): novas interfaces paisagísticas?”, os autores Gonçalves e Marafon abordam como a proliferação de unidades de conservação privadas no espaço rural, demandantes de novas representações paisagísticas, parece se associar aos segundo e terceiro grupos citados anteriormente. Eles defendem que o fenômeno em questão é acompanhado a priori de uma dinâmica imobiliária que se caracteriza pela crescente demanda de atores citadinos de médio a alto poder aquisitivo à procura de segundas residências (casas de campo e de veraneio, chácaras e sítios) consorciadas ou não a projetos agroecológicos, os quais incorporam a funcionalidade e a integridade de componentes ecossistêmicos como variáveis de valoração paisagística. A mobilização territorial desses atores citadinos produz novos discursos e significados que, paradoxalmente, promovem uma revalorização qualitativa e temática do espaço rural. Assim, entendem como uma forma de ruralidade a lógica espacial dos outsiders urbanos e as relações por eles tecidas no interior dos espaços rurais, inaugurando novos (re)arranjos paisagísticos que têm nas Reservas Particulares do Patrimônio Natural (RPPN) um de seus componentes. Isso tem induzido a uma nova demanda social por bens e serviços ambientais e de lazer, tais como ecoturismo, paisagens "naturais", alimentos e artefatos artesanais. Tal procura, oriunda principalmente de moradores de grandes centros urbanos, constitui-se como uma importante variável de reestruturação rural, sobretudo em áreas mais próximas de grandes metrópoles. 
No capítulo "Turismo rural: resgatando conceitos e atualizando reflexões” os autores Lima e Marafon apontam como as atividades turísticas no campo desempenham o papel de mais uma fonte de renda para muitas famílias, contribuindo para a manutenção e a reprodução das atividades agrárias. Enfatizam que a preservação e a proteção da natureza, a valorização e a busca da autenticidade dos elementos paisagísticos locais, a conservação e a proteção dos patrimônios históricos e culturais e o resgate da memória e da identidade são importantes fatores na mercantilização das paisagens, com a consequente expansão das atividades de turismo e de lazer. Essa realidade já se faz presente nos campos de todos os estados brasileiros, como o caso observado na relação campo-cidade nos estados da Paraíba e do Rio de Janeiro - em análise nesse texto -, identificando o turismo rural como importante elemento de transformações nas áreas rurais. Destarte, aprofundam a reflexão acerca das atividades turísticas em espaços rurais, resgatando noções sobre como estas se organizam em segmentos para fins de estratégias de planejamento, recurso importante de ser observado na busca pela melhor compreensão do comportamento altamente dinâmico desse complexo fenômeno. Os autores também identificam que a cada dia surgem novos temas sobre o turismo, respondendo ao apelo de impulsos específicos que levam aos deslocamentos e às viagens. Para eles, pensar a segmentação do turismo para além das noções de mercado e de concorrência é um desafio que leva ao esforço de capturar do fenômeno turístico a sua essência, ou seja, o potencial transformador inerente à experiência turística que pode ou não se realizar. Nessa perspectiva, a força transformadora do turismo parece estar mais presente em alguns temas, como é o caso do turismo rural. Assim, as múltiplas concepções sobre o turismo praticado no espaço rural têm tantas vertentes quanto são os recortes possíveis de serem feitos em relação ao que pode ser considerado rural, enriquecendo a diversidade de conceitos e a gama de vivências turísticas. É nesse contexto das relações globais e frenéticas da atualidade que os referidos autores buscam atualizar as reflexóes sobre o turismo rural, no enredo do território e do espaço.

No capítulo "A dimensão espacial da atividade turística no território fluminense", para os autores Nunes e Ribeiro, o turismo, atividade econômica que move milhões de pessoas anualmente pelo mundo, tem no estado do Rio de Janeiro importante recorte espacial de desenvolvimento. A abrangência do setor extrapola a Região Metropolitana e encontra em municípios do interior atrativos capazes de alavancar as economias locais. Nesse sentido, estabelecem 
como objetivo do referido capítulo apresentar a dimensão espacial do turismo no estado do Rio de Janeiro. Para tanto, o mesmo encontra-se dividido em três partes: a primeira procura evidenciar as condicionantes para o desenvolvimento das práticas turísticas nos municípios fluminenses, como o elemento físico ou natural, o elemento histórico e as atividades econômicas, e o papel dos transportes; a segunda parte trata da institucionalização da atividade no estado, partindo da década de 1960, quando são criadas as primeiras empresas públicas voltadas para o setor, abordando ainda os planos, as tipologias e as classificações oficiais desenvolvidas para os municípios fluminenses; e, por último, abordam ainda a categorização desenvolvida pelo Ministério do Turismo para analisar brevemente o processo de consolidação dessa atividade como importante vetor econômico dos municípios de Angra dos Reis, Paraty, Armação dos Búzios, Cabo Frio e Rio de Janeiro, classificados pela referida instituição como de categoria A. A metodologia utilizada consiste no levantamento bibliográfico acerca do lazer, do fenômeno turístico e sua institucionalização e do processo de ocupação e desenvolvimento econômico dos municípios fluminenses. Dessa forma, para os autores, a dimensão espacial do turismo merece uma profunda reflexão, pois, no estado do Rio de Janeiro, essa atividade tem importância econômica destacada para diversos municípios fluminenses.

No capítulo "Ser 'carioca'/ser 'fluminense': la creación de identidades por las fronteras politico-administrativas en el espacio sudamericano", para Pinheiro da Silva, a criação de identidades territoriais é dada por meio de historicidades espaciais associadas a movimentos político-administrativos e econômicos em tempos e espaços específicos. O autor assinala que uma das características mais marcantes dessas criações é a fronteira, um mecanismo limite e definidor de projetos de políticas territoriais, cujos agentes históricos instituídos devem ser identificados na pesquisa acadêmica das ciências sociais e políticas. Assim, a cidade-estado do Rio de Janeiro, Brasil, tem uma história sui generis na criação de suas identidades socioespaciais, expressa não apenas em seus diferentes territórios, mas também em perspectivas antropológicas e sociológicas diferenciadas, com forte impacto no espaço brasileiro. Dessa forma, a construção do "ser 'carioca' e ser 'fluminense'" no país está envolvida em condiçôes espaciais muito diferentes nos seus respectivos territórios, reforçando a ideia de que hoje, contra a metropolização no mundo, as fronteiras territoriais são fluidas. Destarte, para Pinheiro da Silva, entre o estatuto de "cidade real" do Rio de Janeiro, no século XVII, e sua situação geopolítica como a sede do Reino de Portugal, no século 
XIX, a sua separação da província do Rio de Janeiro em 1834, seu status como Distrito Federal (1891-1960) e de capital de uma unidade federativa (1975), depois mesclando-se após quase 150 anos de separação da província fluminense, as diferentes gestões políticas além fronteiras não impediram que a vida social desses dois fragmentos territoriais mantivesse suas questões geográficas. E essas são questões fundamentais para a compreensão do Rio de Janeiro, hoje, e para os estudos metropolitanos do Brasil.

En la segunda parte, denominada "Estudios territoriales en Costa Rica", y compuesto por cinco capítulos, Lilliam Quirós Arias, en el capítulo "Políticas Públicas habitacionales: la vivienda social en Costa Rica”, se hace un análisis de las acciones de la política pública costarricense, que atiende las necesidades de vivienda de la población de escasos recursos económicos y su relación con las políticas de ordenamiento territorial. En contexto se plantea, que en el país el crecimiento urbano principal se ubica en el Gran Área Metropolitana (GAM). Con una concentración poblacional, desordenado y de forma horizontal, aunado a la carencia de una planificación del nivel regional. Aun así la Política Nacional de Ordenamiento Territorial, del Ministerio de Vivienda y Asentamientos Humanos (MIVAH), es un instrumento valioso para avanzar en este proceso. Para este análisis, Quirós hace un recuento cronológico de las diferentes políticas relacionadas a este tipo de vivienda en el país, que van desde los años 40s del siglo XX, hasta los inicios de la administración Solís Rivera (2014-18), referentes a la legislación y a la creación de instituciones con el fin de atender la situación de la vivienda de bien social y la problemática de la vivienda de la clase media, complementando con datos estadísticos de diferentes ministerios, instituciones y organizaciones nacionales. Dando énfasis en los siguientes subtemas: surgimiento de instituciones públicas para atender las necesidades de vivienda, la vivienda en el marco de la creación del sistema nacional del hábitat humano, el sector de la vivienda en costa rica, servicio financiero nacional de la vivienda (SFNV) social y el bono de la vivienda, características y distribución geográfica. Como consideraciones finales la autora indica que existen esfuerzos importantes en la política pública para promover la integración de la vivienda con el ordenamiento territorial y asentamientos humanos, que el tema vivienda de bien social, posen una amplia normativa y se cuenta con un sistema financiero estratificado en bonos individuales y colectivos. Aun así la carencia o desactualización de los planes reguladores limitan la capacidad de planificación territorial. Por otra parte se ha propiciado 
un modelo de urbanizaciones para todos los estratos sociales, y condominios para las clases altas. Manteniendo siempre el modelo de crecimiento urbano horizontal, con las tendencias inmobiliarias de viviendas alejadas de la ciudad, desaprovechando el potencial de servicios y centralidades que ofrecen las áreas urbanas, propiciando la degradación de los recursos naturales. También que se deja en manos de desarrolladores las decisiones que determinan el tipo de oferta disponible en el mercado (tipología de la vivienda) y el lugar donde será satisfecha la demanda por viviendas. Se tiene un sector de la clase media que se incorpora recientemente como una prioridad de atención, dado que no tiene acceso a la vivienda, tanto como por la disponibilidad de recursos como la oferta inmobiliaria disponible.

En el capítulo denominado, "Planes de sostenibilidad turística para el turismo rural comunitario de Costa Rica: metodología para su elaboración”, los autores, Alvarado y Miranda, presentan una sistematización de la metodología diseñada e implementada en los proyectos de extensión universitaria, en la Escuela de Ciencias Geográficas de la Universidad Nacional de Costa Rica (UNA), para la elaboración de planes de sostenibilidad en iniciativas de Turismo Rural Comunitario (TRC). Al inicio hacen referencia a la evolución del turismo costarricense, donde los procesos de transformación de la actividad turística desde la década de los años 80s, llevó al surgimiento del turismo sostenible, que de pasó permeó en las comunidades rurales, por medio del TRC, situaciónque justifica la implementación de esta metodología. En cuanto al referente conceptual, los autores, se centran en definiciones relacionadas el de desarrollo sostenible, el cual fue utilizado por primera vez en 1987 por la Organización de las Naciones Unidas (ONU), como el de turismo sostenible, definido por la Organización Mundial del Turismo (OMT) y Raintforest Alliance, además del concepto de Buenas Practicas de Sostenibilidad Turística, de acuerdo a diferentes guías nacionales e internacionales. Por su parte el contenido de dicha metodología, se basa en la norma del Certificado de Sostenibilidad Turística (CST), decretadas por el Instituto Costarricense de Turismo (ICT), establecida por Decreto Ejecutivo en mayo de 1998 y en la Ley del Fomento del Turismo Rural Comunitario (Ley N. 8724), del 1 de Octubre de 2009. En los resultados, presentan los diferentes procesos para la aplicación de esta metodología, como son: inserción en la comunidad, inducción, evaluación, acompañamiento, campañas comunitarias y finalmente el diseño del plan de sostenibilidad, que se ilustran con datos, derivados de los procesos participativos 
comunitarios. Como consideraciones finales de la investigación, indican que los planes de sostenibilidad, son una herramienta que permite cumplir con las exigencias de la demanda turística a nivel nacional e internacional, además estos son el primer paso para optar a cualquier certificación de sostenibilidad y que también facilitan la creación de encadenamientos locales y articulaciones interinstitucionales.

El capítulo "Geografía de las juventudes: corporeidad y espacialidad urbana”, presentado por la máster Iliana Araya Ramírez, tiene como objetivo analizar las perspectivas teóricas en la construcción de la espacialidad urbana desde la corporeidad y las emociones por parte de las personas jóvenes. Porque los abordajes de la geografía de la juventud han sido poco estudiados, a pesar de ser el mayor grupo demográfico. La juventud es una categoría de análisis de lo social, situada en un tiempo histórico particular y en un espacio cultural definido; donde los jóvenes son una construcción sociocultural de determinada sociedad que se expresa en sus prácticas sociales y culturales. Este grupo etario se apropia de los espacios que devienen en lugares en la cotidianidad, la experiencia de habitar los lugares conforma un conjunto de relaciones, y a la vez, éstas se explican por las estructuras y las prácticas socio-espaciales de cada ciudad en particular. De acuerdo a la localización geográfica, la juventud participará en la vida urbana para apropiarse de los lugares, aunque algunas veces podrá ser excluido de estos (Horschelmann y Van Blerk, 2013). En la primera parte de este capítulo se aborda la espacialidad urbana desde la perspectiva de la juventud y su diferenciación según sean sus características respecto al género, la clase y el lugar de precedencia. En el segundo apartado se conceptualiza al espacio público y su función social como un lugar donde la juventud establece relaciones sociales a partir de las cuales cimenta su espacialidad; destaca la importancia de la alfabetización callejera como parte de las formas de apropiarse de los lugares. En el tercer apartado plantea la relación entre corporalidad, espacialidad y emociones y la forma que esta deriva en prácticas socio espaciales, ya sea de permanecer o desplazarse; en este sentido la experimentación del lugar deviene de la actuación y la convivencia en la ciudad. Finalmente, el último apartado se propone las relaciones proxémicas en las escalas de la espacialidad urbana elaboradas a partir de las relaciones sociales que inician en la escala del cuerpo, la casa, la calle, el barrio, la ciudad y el ámbito metropolitano. Como consideraciones finales la Máster Araya, plantea que la juventud como categoría de análisis constituye un constructo socio cultural que está expresada en sus prácticas socio espaciales donde articulan 
los espacios públicos de las ciudades. La espacialidad urbana respecto al uso del espacio público presenta variantes según sean las escalas de proximidad, donde la centralidad de la calle asume rasgos definitorios en la construcción de la espacialidad urbana porque constituye un lugar de aprendizaje. Aunado a lo anterior la aceleración de la sociedad actual en la expansión del sistema capitalista transforma las dimensiones espacio temporales; también cambian las nociones de proximidad. Si bien la espacialidad urbana está configurada en diferentes escalas de proximidad, también hay un recorrer biográfico que inicia en la infancia. Finalmente, las formas de apropiarse del espacio están asociadas con aquellas maneras de pertenecer y relacionarse con los lugares.

Elcapítulo "El ordenamiento del territorioy los procesos en la elaboración de planes reguladores en Costa Rica”, presentado por la máster Lidia Orias Arguedas analiza los conceptos de espacio y territorio como categorías de análisis desde la geografía y sus aportes a la planificación y ordenamiento del territorio, como preámbulo para describir la forma como estos son concebidos en Costa Rica desde las instituciones públicas y el marco jurídico que los acuerpan. Se analizan los factores que influyen en los largos procesos de elaboración y aprobación de los planes reguladores en Costa Rica, tanto en la planificación como en el ordenamiento del territorio, la inacción supera las expectativas para los actores sociales o agentes institucionales que lo enfrentan. Plantea como la orientación de ocupación y manejo del territorio, debe ser competencia del Estado y desde los gobiernos locales, desde la política pública como ordenanza y el marco legal que la refuerza. En Costa Rica el Ordenamiento Territorial (OT) suele considerarse como un rol de las municipalidades, que deben respetar el marco institucional y jurídico vigente, este último establece quiénes son sus responsables en la formulación de planes de OT; el plan regulador se constituye en el modelo de OT en Costa Rica a nivel municipal. El plan regulador como Instrumento de Ordenamiento Territorial, establece las bases y las directrices de la planificación y gestión de nivel local, siendo necesario una gestión sistemática de sus recursos económicos y humanos dirigidos a materializar el ordenamiento o la planificación del territorio. Muchos planes reguladores no se implementan por la carencia en la gestión de los recursos y medios para lograr los objetos de los planes. La autora presenta además una cronología de la suma de procedimientos del marco jurídico administrativo, político y técnico, para la elaboración y aprobación de planes reguladores en Costa Rica, resaltando el rol en la planificación urbana a escala nacional del Instituto de vivienda y 
urbanismo (INVU), y el ordenamiento del territorio (OT) es función de los gobiernos locales, según estipula la Ley de planificación urbana N. ${ }^{\circ} 4.240 \mathrm{del}$ año 1968 , de elaborar y ejecutar sus planes regulares. Así otras instituciones en la financiación y apoyo logístico y de capacitación como Instituto de Fomento y Asesoría Municipal (IFAM) y el Ministerio de planificación nacional y política económica (MIDEPLAN). Se retoma el rol de Secretaria Técnica Nacional Ambiental (SETENA) en la aprobación de la Variable ambiental, la cual contempla en su procedimiento técnico el estudio tres etapas: Índices de Fragilidad Ambiental (IFA), Análisis de Alcance Ambiental (AAA) y el Reglamento de Desarrollo Sostenible (RDS). Además los procedimientos técnicos del Sistema de Nacional de Riego y Avenamiento (SENARA) y la directriz para la elaboración de la Metodología de estudios hidrogeológicos y los términos de referencia para planes reguladores. En el documento se resaltan los esfuerzos por la "flexibilización" para la aprobación de los planes reguladores; como el balance entre la viabilidad técnica y política; dado los intentos fallidos por lograr la aprobación de los mismos en los cantones del país. Se describen las etapas de elaboración de los estudios de planes reguladores, una vez aprobada la variable ambiental, de acuerdo al Manual de Planes Reguladores como Instrumento de Ordenamiento Territorial, del INVU: Fase de Análisis y Diagnóstico, Fase de Pronóstico, Fase Propositiva y Fase de Implementación (gestión). Proceso que culmina con la convocatoria a una audiencia pública y la aprobación de la Dirección de Urbanismo del INVU. La autora concluye que es un privilegio desde la Geografía la profundización de los conceptos teóricos trascendentes como el espacio, el territorio y su planeación y contribuir con los aportes teóricos y metodológicos a la planeación del territorio. Sin embargo la burocracia administrativa impiden que estos procesos de planificación se concreten en propuestas concretas de ordenamiento del territorio.

El capítulo "Modelos de zonificación urbana y su implementación en Costa Rica”, presentado por el Licenciado Omar E. Barrantes Sotela; discute las principales líneas de pensamiento que intervienen en la construcción de una zonificación urbana; analiza para el caso de Costa Rica la implementación de este instrumento en los diferentes procesos de planificación y las características que presenta, así como los inconsistencias y violaciones más comunes a esta normativa. El autor plantea las funciones de la zonificación urbana como instrumentos de regulación en el Ordenamiento Territorial; los diseños de zonificación que se orientan tanto por la regulación, el control y establecer 
patrones de densidades constructivas; así como por la forma y la capacidad de enlazar usos múltiples o mixtos que pueden ser compatibles, creando lugares más confortables para habitar. Estas nuevas prácticas de planificación incluyen un diseño urbano con desarrollo compacto de usos mixtos, protección de áreas naturales y agropecuarias, así como la incorporación de la gestión del riesgo por afectaciones de amenazas (antrópicas y naturales), que incluyen la mitigación del impacto por cambio o variabilidad climática. Una de las principales críticas a la zonificación, se deriva de separar el territorio en zonas según su función predominante o por necesidad de control especial. Su diseño no necesariamente ocurre mediante criterios claros que faciliten las labores de gestión. Como alternativas de regulación urbana los profesionales proponen enfoques que incluyen criterios calidad de vida de los habitantes de un área urbana, a través de la inclusión y mixtura de usos, así como controlar el tamaño y el desarrollo urbano disperso de las áreas periurbanas. En el artículo se desarrollan cinco métodos de regulación urbana según su fundamentación básica: la zonificación por rendimiento, la reglamentación de zonas con derechos de desarrollo transferible, zonificación por incentivo, el modelo de control y administración del crecimiento y por último la regulación por crecimiento inteligente. Se documenta además los modelos de zonificación implementados en Costa Rica; los primeros esfuerzos de zonificación en 1949, la Ley N.o 1.788 que crea el Instituto Nacional de Vivienda y Urbanismo (INVU) y su suplemento la Ley Planificación Urbana N.o 4.240 en 1968; con lo que se inicia formalmente la planificación urbana en Costa Rica. Las posteriores propuestas: Plan GAM-82, el PRUGAM (2008-2030), Plan de Ordenamiento Territorial de la Gran Área Metropolitana (POT/GAM 2011-2030), el Plan GAM 20132030; propuesta esta última que surge ante el fallido intento de aprobación de las anteriores. El autor concluye que a pesar de las propuestas alternativas de zonificación urbana, el abordaje más utilizado en la regulación urbana es el de prueba y error, que se evidencia en como los enfoques alternativos de zonificación se originan, es decir del análisis de los resultados empíricos. Sin embargo, a pesar de que este proceso constructivista no es muy buen visto por un grupo de académicos y especialistas de diversas disciplinas y ciudadanos en general; esta ha sido una respuesta pragmática, al entender que la dinámica urbana sobrepasa la capacidad de gestión que tiene la misma sociedad sobre los espacios que habita y transforma. 
El capítulo "Esbozo con perspectiva geográfica de los estudios sobre la ciudad, el espacio y las cuestiones urbano-regionales en América Latina”, presentado por el Dr. Omar Arrieta Chavarría; presenta un esbozo de las publicaciones realizadas en América Latina, de los estudios relacionados con la ciudad y las cuestiones urbanas; el urbanismo y la planificación; y la cuestión urbana regional y el ordenamiento del territorio. Esto con el objetivo de comprender las experiencias logradas en esta materia, aprender de ellas, y reorientary fortalecer la producción científica sobre estos temas particularmente en Centroamérica. Para estudiar este tema, se identificó algunas instituciones que se destacan por su trayectoria en el campo de la investigación científica y técnica en la temática, se incluyen algunos centros académicos que se ocupan de estos problemas con el fin de sintetizar las principales líneas de trabajo; en el caso brasileño, dado la magnitud de los estudios relacionados se tomó una muestra significativa de universidades, departamentos e institutos brasileños que se dedican al análisis científico y técnico de estos temas. Se realiza además una revisión crítica, detenida de los artículos y textos de la extensa producción que desde diversas disciplinas se ha producido, y que son las líneas fundamentales de trabajo en América Latina. En la exposición, el texto se dividió en tres acápites, el primero hace un repaso de aportes teórico metodológicos sobre la ciudad y el espacio urbano regional vistos desde la geografía; la segunda es una revisión de las cuestiones urbano-regionales y una síntesis de los temas recientes en el ámbito de la geografía con enfoques posmodernos y socio críticos; la tercera es una reflexión de los aportes y posibilidades futuras en las investigaciones de este tipo con miras a enfrentar los retos que se tienen en el campo de las ciencias sociales vinculadas al análisis del espacio geográfico, la ciudad y la cuestión regional, asuntos que interesa profundizar en el caso centroamericano.

Rio de Janeiro e Heredia, outono-primavera de 2018. 
Parte I - Estudos territoriais no Brasil 


\section{Considerações sobre as categorias analíticas do espaço geográfico em Milton Santos}

Mônica Sampaio Machado

Thiago Adriano Machado

\section{Introdução}

A trajetória intelectual de Milton Santos pode ser compreendida a partir de dois projetos por ele desenvolvidos: o primeiro, de produzir uma teoria geográfica, como uma teoria social crítica do espaço; e o segundo, de realizar uma interpretação geográfica do Brasil. ${ }^{1}$ Este capítulo tem por objetivo discutir alguns aspectos da teoria geográfica desse pesquisador, destacando as categorias analíticas do espaço por ele desenvolvidas. Uma breve periodização de sua trajetória distingue três principais momentos, por meio dos quais efetiva a sua produção teórica a partir de aproximações sucessivas da relação entre o espaço geográfico e o fenômeno técnico. Isso ocorre, porém, com uma renovada crítica da tradição geográfica, inclusive daquela em que o autor situa seus primeiros trabalhos.

Podemos, desta feita, identificar uma primeira fase entre 1948 e 1960, caracterizada pelos seus estudos sobre a Bahia, nos quais predominava a geografia regional de matriz lablachiana, sucedida pelo período de exílio entre 1965 e 1987, em que operacionaliza os conceitos marxistas para o estudo da urbanização dos países subdesenvolvidos e, por fim, uma última fase entre 1988 e 2001 ,

Essa ambição que tem sido sinalizada em várias estudos realizados sobre a obra de Milton Santos, como os de Thiago Machado (2017) e Flávia Grimm (2011). 
em que sua teoria geográfica atinge a maturidade em profundo diálogo com a temática da globalização. ${ }^{2}$

Algumas obras se destacam na elaboração dessa teoria geográfica, a exemplo de Por uma Geografia nova, publicada em 1978, que marcou o movimento de renovação crítica da Geografia brasileira, e $A$ natureza do espaço, de 1996, considerada a mais importante da sua produção geográfica por oferecer uma complexa teorização do espaço característica de trabalhos de maturidade. A compreensão das categorias analíticas do espaço passa, contudo, pela exploração de outros trabalhos do autor, nos quais é possível assimilar o desenvolvimento paulatino de sua teorização. Além das duas obras já mencionadas, destacamos também $O$ trabalho do geógrafo no terceiro mundo, primeiramente publicada em francês, em 1971, Espaço e método, de 1985, Metamorfoses do espaço habitado, de 1988, e Técnica, espaço, tempo, de 1994. Todavia, é em A natureza do espaço (1996) que encontramos de maneira explícita a estruturação do seu sistema de conceitos a partir da distinção entre categorias analíticas internas e categorias analíticas externas ao espaço.

Para tanto, Milton Santos (1996) propõe pensar a Geografia, inserida no quadro mais amplo das ciências da sociedade, a partir da consolidação e delimitação de seu objeto de estudo - o espaço geográfico -, elevando-o a ente analítico independente dentro do conjunto das ciências sociais e de extremo valor para a análise e compreensão da sociedade. E, para que o espaço geográfico possa aspirar a ser esse ente analítico independente e indispensável, é fundamental que "os conceitos e instrumentos de análise apareçam dotados de condições de coerência e operacionalidade” (Santos, 1996, p. 18). Essa tarefa, apesar de estar explícita em $A$ natureza do espaço, foi sendo elaborada ao longo de décadas de trabalho do autor, que remontam aos finais dos anos de 1940, a partir do exercício dialético e cumulativo característico da sua forma de produção de conhecimento. Sempre pautado na crítica de estudos anteriores que realizava, Milton Santos incorporava novas leituras e observações do mundo empírico que permitiam dar um passo à frente ao tema investigado e, aos poucos, construíam sua teoria geográfica.

A coerência e a operacionalidade dos conceitos e instrumentos de análise do espaço geográfico estão fundamentadas na técnica, ou melhor, no fenômeno

2 A classificação das produções teóricas de Milton Santos em três fases teve como referência o estudo de Mônica Machado (2014). 
técnico, sustentando o que o autor defende para o campo de estudo da ciência geográfica, não como uma filosofia da natureza, nos moldes amparados na Geografia como ciência moderna do século XIX, mas uma Geografia como uma filosofia das técnicas, na medida em que as técnicas medeiam a relação humana com o mundo (Santos, 1988b). As técnicas devem, portanto, ser vistas sob um tríplice aspecto: como reveladora da produção histórica da realidade; como inspiradora de um método unitário; e como garantia da conquista do futuro, desde que pensada como fenômeno técnico (Santos, 1996, p. 20).

Por seu turno, a operacionalidade é efetivada na capacidade de a Geografia corresponder às mudanças da sociedade, atualizando a teoria conforme a realidade, ao que Milton afirma toda teoria ser revolucionária, pois se encaminha para superar as velhas ideias e buscar investigar o terreno desconhecido do real. Em termos operacionais, podemos citar os trabalhos em que o autor dedicou-se ao Brasil, especialmente A urbanização brasileira, de 1993, e O Brasil: território e sociedade no início do século XXI, de 2001. Porém, as categorias analíticas por ele empregadas também ostentam o potencial explicativo do mundo contemporâneo a partir do fenômeno da globalização. Nesse sentido, o fundamento técnico do meio geográfico é uma importante contribuição ao produzir uma periodização do território, que encontra o seu ponto alto no meio técnico-científico-informacional, a partir do qual os atributos técnicos do espaço respondem às demandas organizacionais que se articulam em redes globais.

A partir daí podemos identificar as categorias analíticas internas ao espaço. Algumas remontam aos conceitos tradicionais da Geografia, outras são novas expressões conceituais resultantes da dinâmica do espaço geográfico contemporâneo que a ciência geográfica deveria incorporar nos seus estudos, como "paisagem, configuração territorial, divisão territorial do trabalho, espaço produzido ou produtivo, rugosidades e formas-conteúdo" (Santos, 1996, p. 19). A essas categorias analíticas, aqui apresentadas pelo autor, adicionaríamos mais algumas, como tecnosfera, psicosfera, lugar, região, redes, escalas, meio técnico-científico-informacional e território usado. Todas têm em Milton Santos uma base fundamental - já assinalada anteriormente -, a base técnica do meio geográfico. E é a partir da base técnica que essas categorias de análise devem ser atualizadas e interpretadas.

Assim, para o desenvolvimento e o estudo das categorias internas ao espaço geográfico, o referido autor apresenta a indispensabilidade da incorporação da técnica ao território como resultado de todo um processo histórico e 
cumulativo da relação entre sociedade e meio, que, por sua vez, promove novas organizações espaciais, impactos e normas jurídicas. Desse modo, ele produz um sistema particular de conceitos que fundamenta a sua teoria no reconhecimento do espaço como um híbrido, um conceito relacional que opera na conjunção do material e do imaterial.

Com o intuito de debater o problema e a formação de suas categorias analíticas, iniciamos com a discussão sobre a Geografia como viúva do espaço, ideia apresentada em Por uma Geografia nova (1978), provocação do autor para ressaltar a crise da Geografia na década de 1970 e a necessidade de pensá-la a partir do seu objeto, o espaço geográfico, como um produto social. Em seguida, buscando discutir e contextualizar essas categorias analíticas na teoria geográfica do autor, será assinalada a centralidade da técnica e sua incorporação ao território nos estudos por ele realizados. Por fim, será apresentada separadamente a concepção de meio técnico-científico-informacional proposta por Milton Santos e por ele utilizada para a análise do caso brasileiro, por nós considerada uma das construções conceituais mais importantes e essenciais de sua teoria geográfica.

\section{Geografia, viúva do espaço}

O desenvolvimento da Geografia moderna até meados do século XX pôs como principal dilema ao campo disciplinar a definição de si mesmo, tema recorrente em face da busca pelo estatuto de cientificidade e das inúmeras questões metodológicas que envolviam a associação dos aspectos físicos e humanos do meio geográfico em um mesmo campo disciplinar. Nesse sentido, o embate entre uma Geografia geral (nomotética) e uma Geografia regional (idiográfica) como eixo definidor do saber geográfico dividiu grande parte da comunidade científica dessa área de conhecimento. ${ }^{3}$

3 Esta discussão foi celebrada no embate desenvolvido entre Richard Hartshorne e Fred Schaefer. Hartshorne publicou, em 1939, The Nature of Geography, argumentando que a Geografia deveria ser definida a partir do seu método e este seria o método regional. Em 1953, foi publicado o artigo de Schaefer, "Excepcionalism in Geography: a methodological examination”, no qual criticava profundamente a centralidade do conceito de região no pensamento geográfico por meio do que ele chamou de "excepcionalismo", argumentando que isso era responsável pelo frágil estatuto de cientificidade da Geografia. A crítica formulada por Schaefer foi 
Milton Santos, em O trabalho do geógrafo no Terceiro Mundo (1978), recupera essa discussão e questiona o conceito de região, definido tradicionalmente pela relação entre os grupos humanos e seus respectivos meios geográficos, identificando as singularidades das áreas. Reconhecendo a intervenção de processos externos à região, Santos recorre ao conceito de "paisagens derivadas", de Maxmillien Sorre, o que lhe permitia lidar com as paisagens de países subdesenvolvidos, que resultam de necessidades econômicas e de ações oriundas dos países desenvolvidos. Dessa forma, não é mais possível tratar da região por meio da ideia até então consolidada de personalidade regional e autônoma, bem característica da Geografia lablachiana.

$\mathrm{O}$ autor ratifica também sua releitura crítica do pensamento geográfico com a publicação de Por uma Geografia nova (1978), obra na qual parte de formulações marxistas para problematizar os aspectos centrais tanto da Geografia regional tradicional quanto da New Geography, resultado da influência neopositivista dos anos de 1960. Faz isso por meio da reformulação do problema geográfico central, deslocando o questionamento da definição da Geografia para o da definição do seu objeto. Ele argumenta, desse modo, que "destemporalizando o espaço e desumanizando-o, a Geografia acabou dando as costas ao seu objeto e terminou sendo uma viúva do espaço" (Santos, 1986, p. 92). O apego às velhas ideias, a estrutura de cátedras e a reprodução de modelos simbólicos que perpetuam os sistemas de prestígio não permitiam, segundo Milton Santos, à Geografia avançar na elaboração de novos problemas e na preocupação em tratar apropriadamente o seu objeto.

A crescente divisão do trabalho científico havia introduzido o espaço na preocupação de outros campos do saber (economia, ciência política, urbanismo etc.), ao passo que os geógrafos dividiam-se em duas amplas tendências: a de garantir um lugar para a Geografia na classificação das ciências e, assim, elaborar leis e princípios gerais; e a perspectiva de transformaá-la em conhecimento operacional ao planejamento sem, contudo, refletir sobre as demandas efetivas e potenciais (Santos, 1986). Como resultado de tais tendências, respectivamente, especulativa e pragmática, produziu-se uma negligência à reflexão e à pesquisa científica que lidasse com o seu objeto de estudo, o espaço geográfico. Milton Santos propõe como solução da crise da Geografia, expressa nessa

central para a introdução do neopositivismo no pensamento geográfico, de forma a fornecer as bases para a consolidação da chamada "New Geography". 
viuvez do espaço, uma formulação teórica que defina o espaço geográfico como objeto central, reconhecido como fato social, fator e instância social. Assimila, assim, as noções da dialética marxista que possibilitaram o espaço geográfico a dialogar estreitamente com o conceito de formação econômica e social, cuja versão geográfica proposta por Santos, a "formação socioespacial”, introduz e fortalece a concepção desse espaço no quadro das tradicionais instâncias sociais do marxismo (base econômica, superestrutura ideológica e jurídico-política) (Santos, 1977).

Articulado à perspectiva marxista, Milton Santos recorre à noção sartriana de prático-inerte para lidar com a dimensão temporal, efetivada naquilo que ele chama de "rugosidades", ou seja, a permanência das formas espaciais procedentes de modos de produção anteriores e que efetivam novos usos e funções que lhe permitem acompanhar as mudanças na sociedade. É dessa noção espaço-temporal das "rugosidades" que deriva a célebre assertiva do autor, de que "o espaço é uma acumulação desigual de tempos" (Santos, 1986, p. 209). Cada forma ou objeto espacial é a impressão de forças de produção e relações sociais de produção datadas, de sistemas técnicos impressos no meio geográfico e que convivem à revelia das suas diferenças. Contudo, o espaço não é feito apenas de formas, ou seja, o espaço não se reduz à materialidade, mas também se refere àquilo que a anima, as ações humanas que fornecem o conteúdo do espaço expresso pelas funções que cada forma desempenha.

O espaço é, portanto, uma "forma-conteúdo", uma conjunção de materialidade e imaterialidade que corrobora a definição proposta por Milton Santos do espaço como "um conjunto indissociável, solidário e também contraditório de sistemas de objetos e sistemas de ações, não considerados isoladamente, mas como o quadro único no qual a história se dá” (Santos, 1996, p. 51). Para tal formulação, o autor ressalta que é essencial a noção de totalidade, a unidade de movimento que integra sociedade e espaço, de maneira que, se a sociedade é o Ser, o espaço é a existência, pois as ações humanas apenas existem, concretizam-se, no espaço (Santos, 1996). Porém, objetos e ações são a forma acabada dessa teorização de Milton Santos.

Anteriormente, outras categorias analíticas já haviam sido utilizadas pelo autor em sua teorização sobre o espaço geográfico. Em Espaço \& método (1985), Santos recorreu à forma, função, estrutura e processo para lidar com a realidade espacial, de modo que o processo remetesse ao movimento temporal, a forma ao aspecto estritamente material do espaço, ao tempo que a função indicasse os 
usos e práticas sociais nas formas espaciais. Por seu turno, a estrutura refletia a totalidade social da qual o espaço é uma instância entre outras, realizando a tarefa de ser uma condição condicionada. Já em Metamorfose do espaço habitado (1988a), os fixos e os fluxos são apresentados na mesma lógica dos objetos e ações, reproduzindo a ideia de espaço como forma-conteúdo.

Outros pares dialéticos reproduzem a mesma noção, a exemplo dos circuitos espaciais de produção e círculos de cooperação, tecnosfera e psicosfera, configuração territorial e relações sociais. A categoria analítica paisagem é somada a tal discussão ao se referir às formas espaciais, porém vinculada à ordem do sensível, à percepção, o que para Milton Santos a distingue do espaço, pois se a paisagem é a materialização de um instante da sociedade, o espaço contém o movimento, é a soma da paisagem com a sociedade (Santos, 1988a, p. 72). Contudo, é importante conhecer como essas categorias se articulam em seu projeto de produzir uma teoria geográfica como uma teoria social crítica do espaço, a partir da técnica.

\section{As categorias analíticas do espaço geográfico em Milton Santos}

Buscando elaborar uma teoria social crítica do espaço, Milton Santos procura construir um arsenal particular de conceitos e categorias importantes capazes de viabilizar uma análise mais reveladora do espaço geográfico contemporâneo. Porém, ainda que muitos conceitos sejam obra da sua criatividade intelectual, partem de uma releitura crítica da tradição geográfica na qual ele próprio foi formado. Tal tradição desenvolveu-se em torno de duas grandes problemáticas definidoras da disciplina: o estudo da diferenciação do espaço na superfície terrestre e o das relações homem-meio. ${ }^{4}$ Cada qual foi, ao seu modo, operacionalizada por correntes teórico-metodológicas distintas, e é possível afirmar que não houve proposição teórica geral na Geografia que não buscasse integrá-las. Da mesma maneira, o autor pretendeu conduzir sua teorização geográfica integralizada numa relação homem-meio, compreendida como produção do espaço, e numa diferenciação espacial convertida em organização do espaço, cada qual remetendo, respectivamente, à centralidade da técnica e da divisão territorial do trabalho.

4 Horácio Capel (2012, p. 241). 
A partir disso, é possível identificar as categorias internas ao espaço que, combinadas, permitem a análise geográfica apropriada, conforme a proposta teórica do autor. Dessa forma, a perspectiva da produção do espaço indica a importância de compreendê-lo como um híbrido, uma "forma-conteúdo", resultado da transformação da natureza por meio do trabalho, porém, o processo do trabalho é então definido a partir de como se produz, e não o que se produz, daí a centralidade do fenômeno técnico para a análise espacial. ${ }^{5}$ Isso se converte na produção dos objetos técnicos, dos fixos e das formas, as quais, arranjadas espacialmente, constituem aquilo a que Milton Santos chama, se pensado estritamente em sua dimensão material, de configuração territorial. Por outro lado, a produção dos objetos é o resultado das ações, dos fluxos e das normas provindas de distintos sujeitos espaciais, homens e mulheres, empresas, governos, organizações locais, nacionais e internacionais.

Todavia, o espaço produzido está em permanente movimento, é uma totalidade em processo de totalização, cujos momentos parcelares dão a indicação da dinâmica da realidade, mas não a apreendem em seu todo. Para tanto, Milton recorre à dimensão temporal, pois sua conceituação do espaço busca conjugar a ação, o espaço e o tempo numa perspectiva relacional. Por isso, uma das suas principais críticas à Geografia tradicional é que esta teria se dedicado excessivamente às formas e pouco à formação (Santos, 1979). Daí, sua preocupação em pensar a formação socioespacial como a sucessão histórica de meios geográficos (natural, técnico e técnico-científico-informacional), uma geografia histórica da produção do espaço, em que cada período é caracterizado pela mediação técnica da relação entre a sociedade e o meio (Santos, 1977).

O espaço, portanto, permite empiricizar o tempo, torná-lo concreto, de modo que, se voltarmos a um momento específico da materialidade espacial, podemos supor e investigar, tal qual um trabalho de arqueólogo, a dinâmica social correspondente às distintas temporalidades impressas no espaço. A partir de então, emergem algumas categorias analíticas, tais como rugosidades, paisagem e configuração territorial. O conjunto de objetos técnicos e elementos naturais compõe a configuração territorial, áreas de preservação

5 Milton Santos ratifica aqui a afirmação de Marx de que "o que distingue as épocas econômicas umas das outras, não é o que se faz, mas como se faz, com que instrumentos de trabalho" (Santos, 1996, p. 46). É a partir dessa noção que, para Milton, o espaço torna o tempo empírico, permitindo a datação dos objetos geográficos pela técnica contemporânea à sua produção. 
ambiental, usinas hidrelétricas, estradas, plantações, florestas e pântanos. Esse conjunto é também o que Milton Santos denomina de sistemas de engenharia, que exprimem, em cada período da história humana, a presença da técnica no espaço. À medida que o meio é ampliado em seus componentes técnicos e informacionais, ampliam-se o domínio e a esfera da técnica, a tecnosfera, o ambiente construído, composto de crescentes densidades técnicas e informacionais, que, por sua vez, apresentam uma nova atmosfera vinculada diretamente às crenças, desejos, hábitos, etc., criando novo espírito de uma época, uma psicoesfera. Já a paisagem é, para Milton Santos, um recorte da configuração territorial, é um momento do espaço apreendido sensivelmente, viabilizado pela percepção (Santos, 1988).

A percepção da paisagem, todavia, não é ainda o conhecimento, mas um processo de apreensão seletivo que permite a existência de diversas visões e pontos de vista sobre a mesma realidade geográfica. Paisagens naturais e artificiais são, nessa perspectiva, o retrato de uma parcela da configuração territorial, mas não podem se confundir com o espaço, como apontado anteriormente, pois, a este, somam-se os movimentos, os fluxos e as açôes - a dinâmica social da qual a paisagem expressa a aparência sem, contudo, chegar propriamente à essência. Nesse sentido, Milton Santos contraria a tradição geográfica que durante décadas centrou-se na paisagem e na região, transformando ambos os conceitos em quase sinônimos, de modo a inserir a morfologia da paisagem de Carl Sauer na crítica à predominante preocupação geográfica com as formas.

Porém, as ações que produzem e animam os objetos também compõem o espaço. São ações teleológicas e racionais, mas também paixões e ideologias que constituem a psicosfera, mencionada anteriormente (Santos, 1994). Essas ações expressam-se em distintas escalas, podendo partir de contextos locais ou regionais, como também agir segundo normas internacionais que submetem os lugares a um acontecer hierárquico, impondo novos fluxos que alteram o funcionamento dos fixos e mudam sua ordem de valor. Tais ações produtoras de espaço, ao modificarem a natureza, também a diversificam, produzindo, a partir daí, uma diferenciação gerada pela divisão do trabalho, que resulta em uma nova organização desse espaço. Essa divisão converte-se crescentemente em divisão territorial, pondo em evidência os recortes espaciais que ditam categorias analíticas tradicionais da Geografia, a exemplo do lugar, da região, das redes e das escalas. 
O espaço é, portanto, organizado econômica e politicamente, integrando no território os distintos momentos da produção, da circulação, da distribuição e do consumo. ${ }^{6} \mathrm{~A}$ rede urbana e os circuitos produtivos são categorias analíticas aí empregadas, mas que têm sofrido importantes mudanças nas suas capacidades explicativas, especialmente no período da globalização. $\mathrm{O}$ modelo tradicional inspirado na teoria dos lugares centrais, no qual a rede urbana é compreendida numa rígida hierarquia vertical, é contestado pelos vínculos globais, que atingem os lugares sem a necessidade de passarem por entes territoriais intermediários. Da mesma forma, a noção de circuitos regionais de produção, característicos do regime de acumulação fordista e da ideia de região homogênea, é reformulada por Milton Santos como circuitos espaciais de produção, os quais podem integrar toda sorte de atores em níveis escalares diversos (Santos, 1988a, p. 48).

Uma nova economia política do espaço se instala, agravando a seletividade espacial que estrutura a organização do espaço em rede e põe em questão a predominância da contiguidade espacial como definidora dos padrões geográficos. As redes modificam a relação entre os fixos e fluxos ao alterarem o conteúdo técnico e organizacional dos objetos no espaço, efetivando a prevalência das verticalidades, em detrimento das horizontalidades (Santos, 1994).

Dessa forma, os lugares ficam crescentemente submetidos a técnicas de produção e a normas privadas e públicas remotas, que transcendem o território político local e nacional. O valor dos lugares muda, pois muda a divisão territorial do trabalho, cada vez mais internacionalizada e submetida às variações da economia política internacional.

Essas transformações promovem também efeitos sobre o cotidiano, confrontando o lugar e o mundo, a ordem local e a ordem universal, a contiguidade e as redes. É no lugar que o espaço realiza a existência, em que todos os atores se

6 Uma importante contribuição de Milton Santos ao estudo da organização do espaço foi a teoria dos dois circuitos da economia urbana, na qual pretendia compreender a especificidade do fenômeno urbano nos países do Terceiro Mundo por meio da bipolaridade de suas economias urbanas, cindidas entre um circuito superior e um circuito inferior. Apresentada no seu livro "O Espaço Dividido", cuja primeira edição data de 1975 em francês, essa teoria alçou Milton Santos ao debate internacional sobre as políticas de desenvolvimento e o efeito das modernizações. Contudo, esse desenvolvimento teórico não está presente nas suas últimas obras, a exemplo de "A Natureza do Espaço", 1996. 
concretizam, existem, de modo cooperativo ou conflitivo, e a essa realidade que Milton chama de espaço banal, o espaço concreto da existência dos homens, das firmas, dos governos (Silveira, 2011).

A localidade se opõe à globalidade, mas também se confunde com ela. O mundo, todavia, é nosso estranho. Entretanto se, pela sua essência, ele pode esconder-se, não pode fazê-lo pela sua existência, que se dá nos lugares. No lugar, nosso Próximo, se superpõem, dialeticamente, o eixo das sucessões, que transmite os tempos externos das escalas superiores, e o eixo dos tempos internos, que é o eixo das coexistências, onde tudo se funde, enlaçando, definitivamente, as noções e as realidades de espaço e de tempo (Santos, 1996, p. 258).

\section{O meio técnico-científico-informacional e o território brasileiro}

As técnicas têm sido, com frequência, consideradas em artigos e livros de geógrafos, sobretudo em estudos empíricos de casos. Mas é raro que um esforço de generalização participe do processo de produção de uma teoria e um método geográficos (Santos, 1996, p. 27)

O meio geográfico no sistema teórico de Milton Santos está presente em toda a sua trajetória intelectual, entretanto, associado à técnica que na sociedade contemporânea constitui uma verdadeira prótese ao território, é o eixo interpretativo central de sua teoria. Nesse sentido, é importante a integração da técnica ao território, algo que, segundo o autor, não foi, todavia, explorada, apesar de a "principal forma de relação entre o homem e a natureza, ou melhor, entre o homem e o meio, ser dada pela técnica. As técnicas são um conjunto de meios instrumentais e sociais, com os quais o homem realiza sua vida, produz e, ao mesmo tempo, cria espaço" (Santos, 1996, p. 25).

Integra-se ao território não somente a técnica, que permite dar coerência ao conjunto de categorias, mas também o tempo, pois é a partir dos sucessivos sistemas técnicos que Milton Santos fundamenta a necessidade metodológica de periodizar. Essa periodização se converte numa sucessão de meios geográficos distintos, que, em um período de longa duração, marca estágios diferenciados da relação da sociedade com o meio. Entretanto, na atualidade, observa-se a associação desses distintos meios técnicos que identificam capacidades e desen- 
volvimentos tecnológicos diferenciados, trazendo dinâmicas também diferenciadas aos territórios e interferindo não apenas no processo produtivo e na acumulação capitalista, mas também nas paisagens, nas configurações territoriais, nos lugares e nas regiões. A partir dessa base teórica, Milton Santos analisa o território brasileiro e sua dinâmica no livro em coautoria com Maria Laura Silveira, O Brasil: território e sociedade no início do século XXI, publicado em 2001.

Para melhor entendermos a concepção de meio técnico-científico-informacional elaborada por Milton Santos e sua aplicação à análise do território brasileiro, vale recuperar o desenvolvimento das suas proposições apresentadas em $A$ natureza do espaço (1996). Como essa concepção, segundo o autor, sustenta-se nas relações históricas entre sociedade e natureza, ela materializa a substituição do meio natural por um meio cada vez mais artificializado. Assim, ele traça a história do meio geográfico em três etapas.

$\mathrm{Na}$ primeira etapa, caracterizada como meio natural ou pré-técnico, o homem escolhia as partes fundamentais do espaço como um exercício da vida e utilizava a natureza sem grandes transformações. As técnicas e o trabalho se casavam com as dádivas da natureza, como a domesticação de plantas e animais. Estas apontavam certo controle do homem sobre a natureza, entretanto predominava uma verdadeira relação simbiótica entre homem e natureza, e o equilíbrio natural era fracamente modificado pela intervenção do homem, sendo logo retomado. $\mathrm{O}$ alcance dessas modificações e suas motivações se davam apenas na escala local.

A segunda fase, identificada como meio técnico, reserva a fase posterior à invenção e aos usos das máquinas, que, unidas ao solo, dão uma dimensão nova ao espaço geográfico. Este passa a ser crescentemente formado pelo natural e pelo artificial. As áreas e países passaram a se distinguir em virtude da incidência desses objetos artificiais, com destaque para os países do Ocidente e do Japão. Há uma mecanização do espaço em termos planetários, e a lógica instrumental passa a desafiar a lógica da natureza, estabelecendo sua superioridade. Os instrumentos técnicos já não são como no período anterior, uma extensão ou um prolongamento do corpo humano, mas prolongamentos do território - verdadeiras próteses. Dominam a razão do comércio e as questões ambientais. A poluição ambiental passa a tomar expressão, principalmente nas grandes cidades europeias do século XIX. Entretanto, o fenômeno da artificialização do meio ainda era limitado às regiões onde a técnica se instalava. Era um fenômeno circunscrito geograficamente. 
Já a terceira etapa, o meio técnico-científico-informacional, caracteriza o período atual, posterior à Segunda Guerra, fortalecendo-se principalmente a partir de 1970. Há grande interação entre ciência, técnica e informação, sob a égide do mercado, agora um mercado global. Ciência, tecnologia e informação são vitais para o progresso contemporâneo, criando processos vitais animais e vegetais. Anteriormente, apenas as cidades concentravam objetos artificiais, técnicos, hoje, o mundo rural está cada vez mais marcado por plásticos, fertilizantes, corantes, computadores etc. A ideia do meio artificial domina a existência contemporânea e apresenta diferenças marcantes em relação às lógicas e às escalas espaciais anteriores: é o domínio da lógica global imposta a todos os territórios. Aumentam os objetos técnicos no território, como o capital fixo (estradas, máquinas, pontes etc.), o capital constante (máquinas, fertilizantes, veículos, sementes) e os fluxos. Rompem-se, assim, os equilíbrios preexistentes, uma vez que cresce a necessidade de circulação, distribuição e consumo da produção em grande escala, e acirra-se a especialização das áreas de produção, como, por exemplo, a soja. Cada vez mais, há a necessidade de intercâmbios com outras áreas, o que promove transformações dos territórios, em razão das redes de comunicação a serviço dos atores hegemônicos, transformando o espaço nacional em um espaço de economia internacional, global. Há um agravamento da crise do Estado, por conta da abertura dos mercados nacionais, promovendo a diminuição da soberania nacional, uma vez que os negócios governam mais do que os governantes.

Assim, o meio técnico-científico-informacional é, para Milton Santos, a condição do espaço geográfico na atualidade. Essa condição demanda um novo sistema de ideias e categorias de análise que, por sua vez, possa estar articulado a uma teoria social crítica do espaço. Na sua última obra (2001), em coautoria com Maria Laura Silveira, o autor procura pensar o Brasil a partir dessas sucessões de meios técnicos diferenciados e apresenta uma interpretação pioneira ao estudo do espaço geográfico brasileiro, descrevendo-o e explicando-o por meio das relações entre técnica, espaço e tempo. Ele oferece como resultado uma aplicação de sua teoria geral do espaço geográfico, demonstrando e reforçando seu papel ativo na dinâmica social. Por intermédio da Geografia, entendida por Milton Santos como uma contribuição específica para a produção de uma filosofia das técnicas, o autor apresenta uma grande contribuição à reconstrução da teoria social crítica e à análise do Brasil. 
Milton Santos oferece uma interpretação do Brasil da globalização, um Brasil em conjunto, como um todo. Aqui introduz a ideia de território usado, que é uma noção central de sua abordagem. Os sistemas técnicos, objetos e formas de fazer, permitem explicar como, onde, por quem, por que e para que esse território é usado. Assim, com base nessa concepção, ele analisa o Brasil a partir dos períodos histórico-geográficos, meio natural, sucessivos meios técnicos e meio-técnico-científico-informacional. Assim, concentra-se no estudo e na identificação do meio técnico-científico-informacional brasileiro, enfatizando a renovação da materialidade do território (construções, rodovias, hidrovias, ferrovias, aeroportos, energia elétrica, telecomunicações, etc.), a informação e o conhecimento, a reorganização produtiva (descentralização industrial, guerra fiscal, Zona Franca de Manaus, Região concentrada etc.), os círculos de cooperação, consequência dos circuitos espaciais da produção (Ceasa, CEAGESP, supermercados, shopping centers, empresas diversas), os fluxos (aéreo, ferroviário, rodoviário, aquaviário, navegação etc.), o sistema financeiro e a distribuição da população e a geografia do consumo.

A partir de então, o autor apresenta a síntese do território brasileiro, reforçando a ideia de território usado como categoria de análise central, e não o território em si. Ele confronta o passado e o presente do território brasileiro, apresentando suas diferenciações, e procura demonstrar a urbanização das cidades médias e grandes e a nova ordem espacial brasileira, que denomina de economia política do território. Um mapa das regiões do Brasil a partir do meio técnico-científico-informacional é oferecido como forma de síntese do país na globalização. As regiões de maior luminosidade são as de maior ciência, técnica e informação, dominando o comando da produção e a articulação internacional. Com efeito, uma proposta de regionalização do Brasil é formulada, tomando como pressuposto a seletividade do meio técnico-científico-informacional, de forma que as porções do território brasileiro em que a técnica e a informação estão mais integradas componham a região concentrada, gerida pela centralidade financeira de São Paulo.

\section{Considerações finais}

O projeto de produção de uma teoria geográfica em Milton Santos sempre esteve articulado aos estudos empíricos, desde os estudos iniciais sobre a Bahia até os últimos trabalhos sobre o território brasileiro. A nossa intenção 
aqui foi trazer uma breve síntese das principais categorias analíticas do espaço geográfico apresentadas por Milton Santos, associando-as à teoria geográfica desenvolvida pelo autor. Conforme demonstrado, essas categorias, estruturadas pela centralidade da técnica, encontram a sua coerência no caráter híbrido do espaço geográfico. Da combinação do material e do imaterial derivam vários pares dialéticos, os quais Milton Santos lança mão para compreender tanto o processo de produção do espaço geográfico contemporâneo quanto os aspectos diferenciais de sua organização.

Como resultado, temos alguns conceitos que, com o tempo, ganharam equivalência em sua teorização ao compartilharem do mesmo ponto de partida, a relação fundamental entre espaço, tempo e técnica. Dessa forma, o espaço geográfico passa a ser considerado como sinônimo de território usado, de meio geográfico e de espaço banal. São conceitos que permitem uma síntese das preocupações teóricas de Milton em pensar a Geografia como uma filosofia das técnicas. Contudo, os seus últimos trabalhos passaram a privilegiar o território usado, muito em decorrência da necessidade de se repensar esse tradicional conceito geográfico no período da globalização, em que as fronteiras passaram a ser questionadas e a crise do Estado nacional pôs em questão a vitalidade dos territórios. Soma-se a isso o interesse do autor em produzir um estudo geográfico do Brasil, cuja peculiaridade estaria em fazer falar o território.

A vasta obra e intensa produção teórica de Milton Santos demandam análises mais apuradas. Aqui, procuramos apresentar apenas algumas considerações sobre as categorias analíticas do espaço geográfico constitutivas de sua teoria geográfica, com o intuito de chamar a atenção para a riqueza e a atualidade do pensamento do autor, mesmo que novos processos estejam em curso e caracterizem a dinâmica contemporânea. Compreender o funcionamento do sistema teórico proposto por ele pode fornecer subsídios para a identificação de instrumentais conceituais mais apropriados aos desafios impostos pelas atuais dinâmicas socioespaciais, em que o conteúdo técnico e informacional atinge novos patamares. Consideramos, por fim, que revisitar as categorias analíticas e a estrutura teórica do espaço em Milton Santos, buscando direcioná-la à análise territorial brasileira, podem auxiliar na compreensão dos desafios e dos possíveis rumos do país diante do novo estágio da globalização. 


\section{Referências}

CAPEL, Horacio. Filosofia y ciencia en la Geografía contemporánea: una introducción a la Geografia. Barcelona: Ediciones del Serbal, 2012.

CONTEL, Fabio B. “Milton Santos”. In PERICÁS, L. B. e SECCO, L. F. (orgs.). Intérpretes do Brasil: clássicos, rebeldes e renegados. São Paulo: Boitempo, 2014.

GRIMM, Flávia C. A. Trajetória epistemológica de Milton Santos: uma leitura a partir da centralidade da técnica, dos diálogos com a economia politica e da cidadania como práxis (tese). Universidade de São Paulo, 2011.

HARTSHORNE, Richard. “The nature of Geography”. Anais da Association of American Geographers, v. 29, n. 3-4, Lancaster, 1939.

MACHADO, Mônica S. "A força do lugar na obra de Milton Santos”. In MACHADO, M. e MARTIN, A. R. Dicionário dos Geógrafos Brasileiros. Rio de Janeiro: 7 Letras, 2014.

MACHADO, Thiago. A. "Da formação social em Marx à formação socioespacial em Milton Santos: uma categoria geográfica para interpretar o Brasil?”. Geographia, v. 18 , n. 38, 2016.

SANTOS, Milton "Sociedade e espaço: a formação social como teoria e como método". Boletim Paulista de Geografia, n. 54, 1977.

. Espaço e sociedade. Petrópolis: Vozes, 1979.

. Espaço e método. São Paulo: Nobel, 1985.

Por uma geografia nova: da crítica da geografia a uma geografia crítica. São Paulo: Hucitec, 1986.

. Metamorfoses do espaço habitado: fundamentos teóricos e metodológicos da geografia. São Paulo: Hucitec, 1988a.

5, 1988b, pp. 9-20.

. "O espaço geográfico como categoria filosófica”. Terra Livre, São Paulo, n. 
. A urbanização brasileira. São Paulo: Hucitec, 1993.

. Técnica, espaço, tempo: globalização e meio técnico-cientifico-informacional. São Paulo: Hucitec, 1994.

.A natureza do espaço: técnica etempo, razão e emoção. São Paulo: Hucitec, 1996.

e SILVEIRA, Maria Laura. O Brasil: território e sociedade no início do século XXI. Rio de Janeiro: Record, 2001.

SCHAEFER, Fred. "Excepcionalism in Geography: a methodological examination". Anais da Association of American Geographers, v. 43. n. 3, pp. 226-49, 1953.

SILVEIRA, Maria Laura. "O Brasil: território e sociedade no início do século XX - a história de um livro”. ACTA Geográfica, Ed. Esp. Cidades na Amazônia Brasileira, pp. 151-66, 2011. 


\section{O setor sucroenergético no Brasil: efeitos e contradições}

Patrícia Francisca de Matos

Gláucio José Marafon

\section{Introdução}

O Brasil tornou-se, há quase duas décadas, um importante produtor e consumidor de biocombustíveis como alternativa energética, com destaque para o etanol produzido a partir da cana-de-açúcar. A necessidade de substituição dos combustíveis fósseis por "combustíveis mais limpos" conferiu uma posição de destaque ao etanol brasileiro. Com o mercado promissor, o Brasil tem visto um crescimento das monoculturas de cana-de-açúcar para abastecer o setor sucroenergético para produção de açúcar, álcool anidro (aditivo para gasolina), álcool hidratado e cogeração de energia (produzida pelo bagaço da cana).

No início do século XXI, ocorreu uma expansão acelerada da cultura da cana no território brasileiro devido ao projeto dos biocombustíveis, que a colocou como a principal opção na produção de álcool, criando novas paisagens, novas formas de produção, e modificando os usos do território, especialmente de oito estados brasileiros.

Para aprofundar a análise, tomaremos como exemplo o avanço do setor sucroenergético no estado de Minas Gerais, especificamente no Triângulo Mineiro/Alto Paranaíba. Esse estado, no contexto da política de incentivos por parte do governo federal para expansão da produção dos biocombustíveis, teve um aumento significativo no volume produzido a partir de 2000 . Cerca de $9 \%$ das 78 milhões de toneladas no Brasil, em 2016, foi produzida em Minas Gerais 
e, destes, 6\%, produzidas no Triângulo Mineiro/Alto Paranaíba. Sendo assim, o presente texto traz uma reflexão acerca do setor sucroenergético no Brasil e em Minas Gerais, com atenção especial para as formas de acesso à cana-açúcar. Para tal, a metodologia pautou-se em revisão teórica e abordagem qualitativa, com levantamento de dados em fontes primária e secundária.

\section{A produção de cana-de-açúcar no Brasil}

A produção de cana-de-açúcar iniciou-se no Brasil na época em que o país ainda era colônia e constituiu, por quase dois séculos, a principal atividade econômica do país. Em razão das condições climáticas e do solo fértil, a cultura da cana-de-açúcar propagou-se pela região Nordeste, despontando como grande centro produtor de açúcar do país.

Após mais de quatro séculos, o cultivo da cana, que teve como principal finalidade a produção de açúcar, passou também a servir como matéria-prima para a produção de álcool, ganhando destaque como uma alternativa de combustível em nível mundial. A produção do álcool de cana-de-açúcar ocorreu devido à crise do petróleo, mais importante fonte de energia utilizada no mundo. Esse novo cenário produtivo da cana no Brasil consolidou-se por meio da extensão territorial, clima favorável e políticas públicas com o intuito de aumentar a produção canavieira.

Das políticas públicas instituídas, a principal foi a criação do Proálcool (Programa Nacional do Álcool), em 1975, considerado um dos maiores programas mundiais de energia renovável. Este tinha o desígnio de estimular o crescimento da produção de cana para a fabricação do álcool, visando a atender às necessidades dos mercados interno e externo. Assim, essa atividade deveria ser incentivada por meio da expansão da oferta de matérias-primas, com ênfase no aumento da produção agrícola, da modernização das usinas existentes e da instalação de novas unidades produtoras. Concomitantemente, as indústrias automobilísticas realizaram adaptações técnicas para que os carros pudessem funcionar com o álcool. Uma década após a instituição do Proálcool, cerca de $90 \%$ dos automóveis leves produzidos eram movidos a álcool.

É nesse contexto que as áreas ocupadas com cana-de-açúcar se expandiram por várias regiões do território brasileiro. Esse crescimento ocorreu tanto no Nordeste (região tradicional na produção de cana) como em novas áreas, como na região Sudeste (conforme tabela 1), que, em dez anos, teve um aumento de 
101.232.152 toneladas, cerca de 224\%. O Sudeste brasileiro foi a região que apresentou o maior crescimento, constituindo-se disparadamente, desde a década de 1975, como o maior produtor. Thomaz Júnior (2002) afirma que, na primeira etapa do programa (1975 a 1979), o estado de São Paulo ficou com a maior parte dos recursos, algo em torno de 35\%. Como consequência, este se consolidou, efetivamente, na produção sucroalcooleira, tornando-se o maior produtor de cana-de-açúcar, dominando, desde a década de 1980, a metade da produção nacional. Além disso, o estado de São Paulo concentra, aproximadamente, $45 \%$ das usinas do país.

Tabela 1: Produção (t) de cana-de-açúcar no Brasil e nas regiões (1975-2000)

\begin{tabular}{ccccc}
\hline Região & $\mathbf{1 9 7 5}$ & $\mathbf{1 9 8 5}$ & $\mathbf{1 9 9 5 / 6}$ & $\mathbf{2 0 0 0}$ \\
Norte & 183.099 & 281.366 & 182.753 & 915.508 \\
Nordeste & 31.130 .630 & 62.624 .054 & 47.075 .814 & 58.856 .00 \\
Sudeste & 45.432 .287 & 146.664 .439 & 173.073 .683 & 217.208 .153 \\
Sul & 2.815 .269 & 12.327 .580 & 20.197 .769 & 24.659 .973 \\
Centro-Oeste & 423.915 & 7.984 .595 & 19.276 .684 & 24.481 .317 \\
\hline Brasil & 79.985 .200 & 229.882 .034 & 259.806 .703 & 326.121 .011 \\
\hline
\end{tabular}

Fonte: IBGE - Censo Agropecuário de 1975, 1985, 1995/6 e Produção Agrícola Municipal (PAM) de 2000. Org: Matos, 2018.

A alta produção de álcool, como alternativa de combustível renovável, durou, em média, quinze anos. Logo, entrou em declínio devido à opção das usinas por produzirem mais açúcar em detrimento do álcool, porque houve o aumento do preço do açúcar no mercado mundial e a queda do preço do petróleo, além da diminuição de subsídios do governo e problemas técnicos nos veículos movidos a álcool.

Após a estagnação do Proálcool, da produção de álcool e da fabricação de veículos movidos a esse combustível, emergiu, no início do século XXI, a fase dos biocombustíveis. Essa nova fase é um movimento comandado pelo governo e também pela iniciativa privada tanto nacional quanto internacional. Novamente, a cana-de-açúcar se tornou a principal fonte de energia da matriz energética. Especificamente, no que se refere ao aparato do Estado, tem-se incentivado a produção agrícola por meio de financiamentos, sobretudo de recursos do BNDES (Banco Nacional de Desenvolvimento Econômico e Social) e isenções fiscais para a instalação de usinas. Concomitantemente, houve o aumento da fabricação dos automóveis flex fuel, ou bicombustíveis, cujo motor tem sensores que reconhe- 
cem os teores da mistura (gasolina e etanol) e se ajustam automaticamente. Com isso, o mercado do etanol viu seu espaço crescer. De acordo com dados da Associação Nacional dos Fabricantes de Veículos Automotores (ANFAVEA), em 2016, do total de licenciamentos de veículos leves no Brasil, $88 \%$ foram flex fuel.

A expansão do setor sucroenergético no Brasil confere a este, junto com os Estados Unidos, a responsabilidade por mais da metade da produção mundial de etanol. A principal matéria-prima utilizada nos Estados Unidos para a fabricação de etanol é o milho, enquanto, no Brasil, é a cana-de-açúcar, considerada uma das alternativas para o setor de biocombustíveis em razão de seu potencial na produção de etanol e subprodutos. Além do etanol e do açúcar, produz energia para suprir as demandas desse processo e vende o excedente para as companhias energéticas.

Assim, ocorre uma acelerada expansão territorial do setor sucroenergético para as áreas do Cerrado, de forma mais acentuada, para a região Centro-Oeste (tabela 2), que passa de uma produção de 37.430.571 toneladas para 142.219.652. A região Sudeste continua em plena expansão, dobrando a produção de 2005 para 2016. É importante ressaltar que, nesse ínterim, os avanços tecnológicos permitiram o aumento da produtividade e a expansão da cultura para novas áreas. $\mathrm{O}$ desenvolvimento de pesquisas para o melhoramento genético da planta e a fertilização do solo, entre outros atributos agronômicos e biológicos, contribuíram para os ganhos na produtividade, que passaram de 46 toneladas por hectare, na década de 1970, para 79 toneladas por hectare três décadas depois. Ou seja, quase duplicou o rendimento por hectare. 
Tabela 2: Produção (t) de cana-de-açúcar no Brasil e nas regiões (2005-2016)

\begin{tabular}{ccccc}
\hline Região & $\mathbf{2 0 0 5}$ & $\mathbf{2 0 1 0}$ & $\mathbf{2 0 1 5}$ & $\mathbf{2 0 1 6}$ \\
Norte & 1.085 .211 & 2.071 .620 & 4.371 .436 & 4.581 .321 \\
Nordeste & 60.874 .754 & 68.789 .726 & 61.546 .275 & 55.698 .720 \\
Sudeste & 291.991 .211 & 498.884 .508 & 499.677 .593 & 517.577 .172 \\
Sul & 31.227 .899 & 50.287 .913 & 48.587 .170 & 48.601 .517 \\
Centro-Oeste & 37.430 .571 & 97.430 .026 & 136.107 .803 & 142.219 .652 \\
\hline Brasil & 422.956 .646 & 717.463 .793 & 750.290 .277 & 768.678 .382 \\
\hline
\end{tabular}

Fonte: IBGE - Produção Agrícola Municipal (PAM).

Org: Matos, 2018.

No que se refere à espacialização por estados, no ano de 2016, em primeiro lugar, temos São Paulo, que cultivou 5.590.586 hectares, atingindo 442.282.329 toneladas; em segundo, o estado de Goiás, com 931.614 hectares e 71.061 .922 toneladas; em terceiro, Minas Gerais, com 911.614 hectares e 69.934.887 toneladas; em quarto, Mato Grosso do Sul, com 658.282 hectares e 51.927.246 toneladas; em seguida, o Paraná, com 656.429 hectares e 46.466.596 toneladas; Alagoas, com 311.641 hectares e 18.982. 504 toneladas; Mato Grosso, com 280.191 hectares e 19.209.764 toneladas; e Pernambuco, com 260.195 hectares e $13.421,235$ toneladas, conforme ilustra o mapa 1. Esses oito estados são responsáveis por $94 \%$ da produção nacional. Os outros estados possuem áreas menores, totalizando, cerca de 6\% da produção do país. 
Mapa 1: Brasil: produção de cana-de-açúcar (toneladas) em 2016

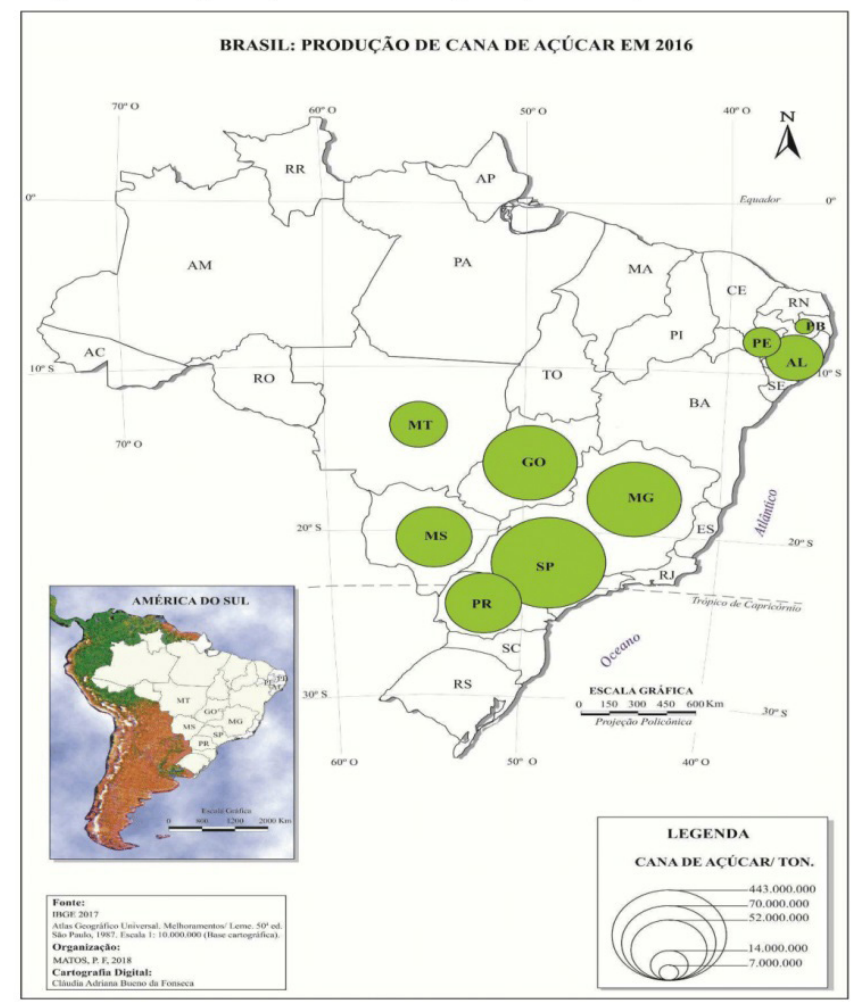

Fonte: Produção Agrícola Municipal (PAM) - IBGE, 2016.

No discurso do governo e dos defensores dos biocombustíveis a partir da cana, consta que as suas vantagens não estão apenas no meio ambiente, mas também na geração de emprego e renda e, consequentemente, no desenvolvimento social e econômico do país. Mais uma vez, na história brasileira, o Estado investe numa atividade que está em curso no mundo com o discurso do desenvolvimento, e agora com um fato novo: a questão ambiental.

Os defensores da agroenergia argumentam que ela emite menos gases poluentes na atmosfera. No entanto, se tomarmos apenas o combustível, depois que está no tanque dos veículos, não será considerado o processo produtivo assentado na monocultura, que utiliza agrotóxicos e fertilizantes. Além disso, a expansão desse setor não se deve a razões ambientais, pois eles não estão preocupados com o meio ambiente ou com o futuro do planeta, mas com a expansão 
do capital. Bombardi e Garvey (2016) mencionam que três cultivos, soja, milho e cana, convergem $67 \%$ de todo o agrotóxico comercializado no Brasil.

Castillo (2009) aponta várias implicações da expansão da cultura da cana no Brasil: a substituição de culturas e ocupação de áreas de pastagens; a oligopolização do setor, com aquisições e fusões de grupos nacionais; a política agressiva de arrendamento de terras por parte das usinas (desestabilizando práticas pretéritas de pequenos produtores); e um amplo conjunto de políticas públicas que viabiliza a expansão do parque de usinas (o que inclui crédito do BNDES, incentivos fiscais, investimentos em logística etc.). Do mesmo modo, o setor sucroenergético provoca muitos efeitos sociais, como a concentração de terras e capitais, impactos na produção de alimentos, especialização produtiva local/ regional e impactos ambientais, muitos, irreparáveis a curto prazo.

\section{Os usos do território pelo setor sucroenergético em Minas Gerais}

A expansão do setor sucroenergético no território brasileiro é pautada na dinâmica da agricultura científica e globalizada. Os municípios que estão direta ou indiretamente ligados à produção da cana transformaram-se em lugares de produção que atendem aos interesses do capital. E esse processo exige o entendimento das formas de apropriação do território. Para Santos e Silveira (2001), o estudo do território deve partir da análise do seu uso.

O território usado permite compreender a nova materialidade, que se manifesta na emergência de macroformas espaciais, as quais estão presentes nas novas formas de regionalização, nas cidades globais, nos movimentos de reestruturação produtiva, no gigantismo da expansão do agronegócio, na escala alcançada pelo mercado e na difusão de ordens através das redes técnicas (Bernardes, 2015, p. 4).

O setor sucroenergético, por meio da expansão da produção da cana, afeta não somente as relações econômicas, como também as relações sociais, políticas e culturais do território e uma nova dinâmica da relação capital e trabalho.

$\mathrm{O}$ estado de Minas Gerais consolidou-se como um dos maiores produtores de cana-de-açúcar do país, resultado da implantação de diversas usinas no seu território, com destacada importância para o Triângulo Mineiro/Alto 
Paranaíba. Em razão dos aspectos físicos, somados à infraestrura da logística e aos incentivos governamentais, tem contribuído para a expansão da produção de cana, firmando-se como uma região estratégica e apropriada para investimentos de grupos nacionais e estrangeiros do setor sucroenergético. No ano de 2016, contava com 23 usinas das 42 existentes no estado (Nova Cana, 2017).

Santos e Silveira (2001) afirmam que as grandes empresas usam de modo seletivo o território, pois escolhem e hierarquizam os espaços mais viáveis para uma produção competitiva. O Triângulo Mineiro/Alto Paranaíba, sobretudo a partir de 2000, passou por nova dinâmica de produção da cana-de-açúcar, podendo ser considerada como uma das regiões competitivas do setor sucroenergético. Para Castilho e Frederico (2010), a região competitiva é a expressão geográfica da produção na era da globalização.

Os dados apresentados no gráfico 1 indicam que a área plantada de cana no estado de Minas Gerais passou de 292.751 hectares, no ano de 2000, para 911.614 hectares, em 2016. Dos 911.614 hectares de área plantada de cana em Minas, 637.268 ficam no Triângulo Mineiro/Alto Paranaíba, colaborando, no referido ano, com $70 \%$ da área plantada do estado. Além do etanol e do açúcar, é gerada energia por meio dos resíduos do bagaço. Minas Gerais produz em média 20 mil gigawatts/hora/ano, conforme informações da SIAMIG (2016). 
Gráfico 1: Área plantada (ha) de cana-de-açúcar em Minas Gerais e na mesorregião do Triângulo Mineiro/Alto Paranaíba (anos selecionados)

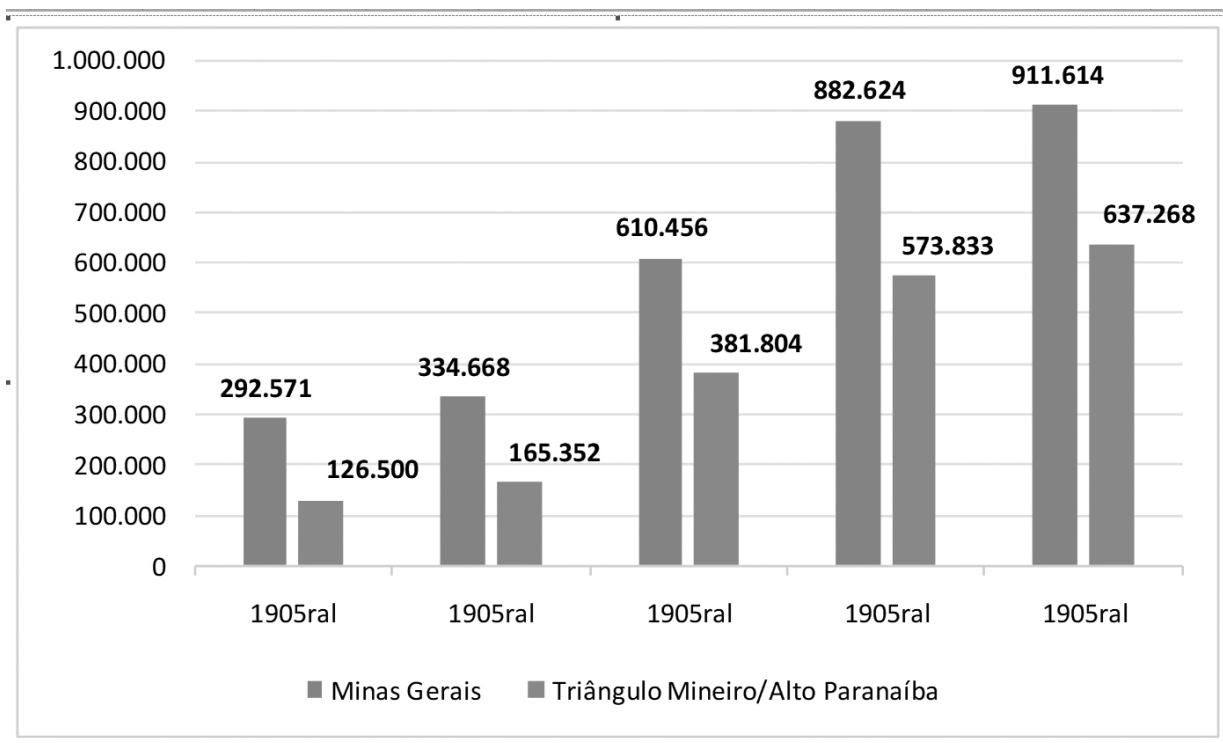

Fonte: Produção Agrícola Municipal (PAM) - IBGE, 2018.

Org: Matos, 2018.

Resultado da área plantada, a produção da cana-de-açúcar no Triângulo Mineiro foi de 10.076.488 toneladas, tendo atingido 50.331.762 toneladas em 2016 , o que trouxe uma contribuição de $72 \%$ do total produzido no estado, ou seja, é uma produção territorialmente muito concentrada (mapa 2). 
Mapa 2: Produção de cana-de-açúcar nas mesorregiões de Minas Gerais Brasil (2016)

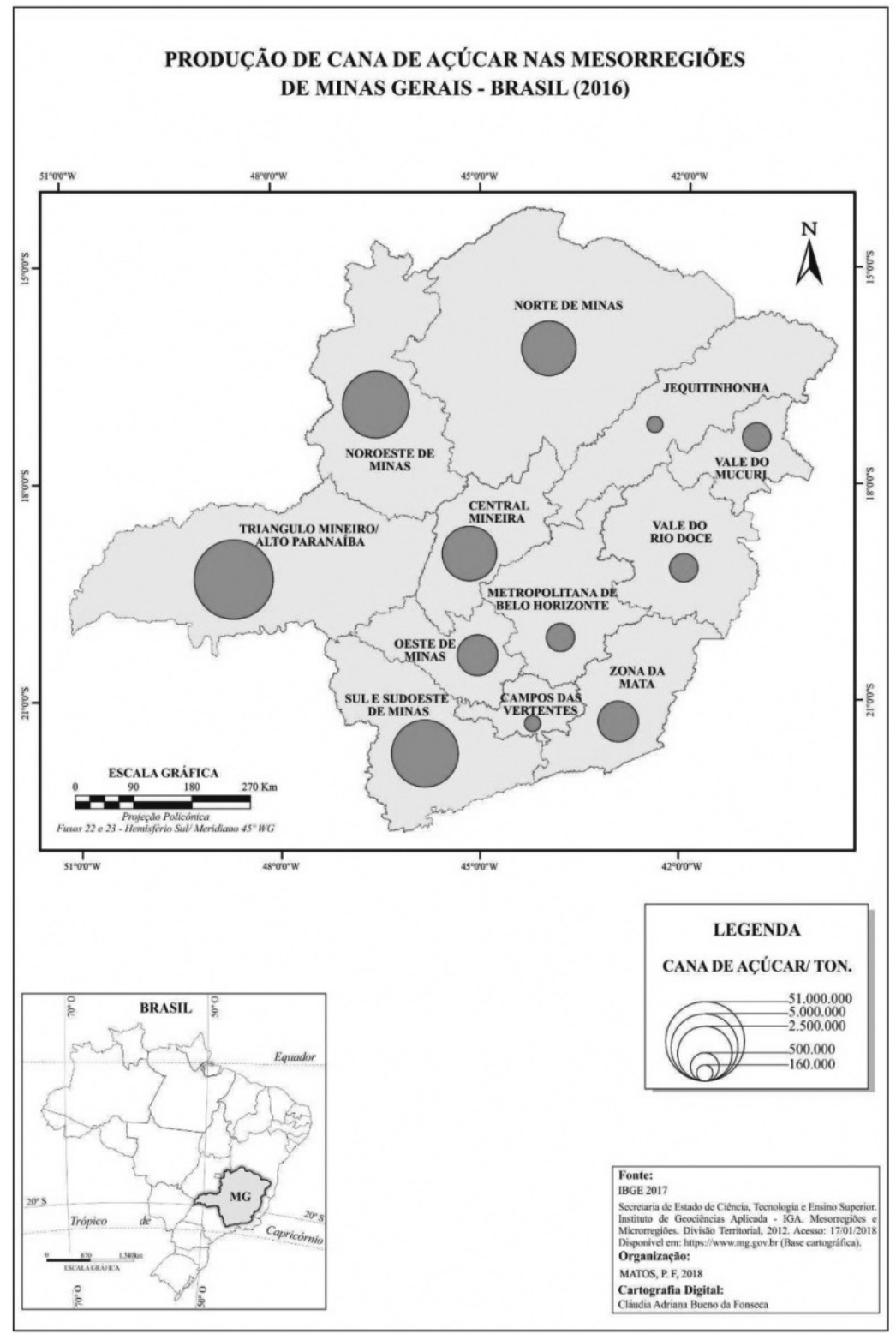

Fonte: Produção Agrícola Municipal (PAM) - IBGE, 2018. 
À medida que ocorre a expansão dos canaviais, acontece o inverso com a produção de arroz e feijão, importantes alimentos para os mineiros e os demais brasileiros. Pelos dados do gráfico 2, observa-se que, em 2000, a região produzia 25.596 hectares de arroz e 23.199 de feijão. O arroz, ao longo dos anos, foi diminuindo, chegando a 2016 com apenas 161 hectares de produção. Já o feijão passou para $40.544 \mathrm{em} 2016$. Somando as duas culturas, no ano de 2016, representaram $6 \%$ da área ocupada pela cana-de-açúcar. A reestruturação produtiva é evidenciada e identificada nos dados e na própria paisagem.

Gráfico 2: Área plantada (ha) de cana-de-açúcar em Minas Gerais e na mesorregião do Triângulo Mineiro/Alto Paranaíba (anos selecionados)

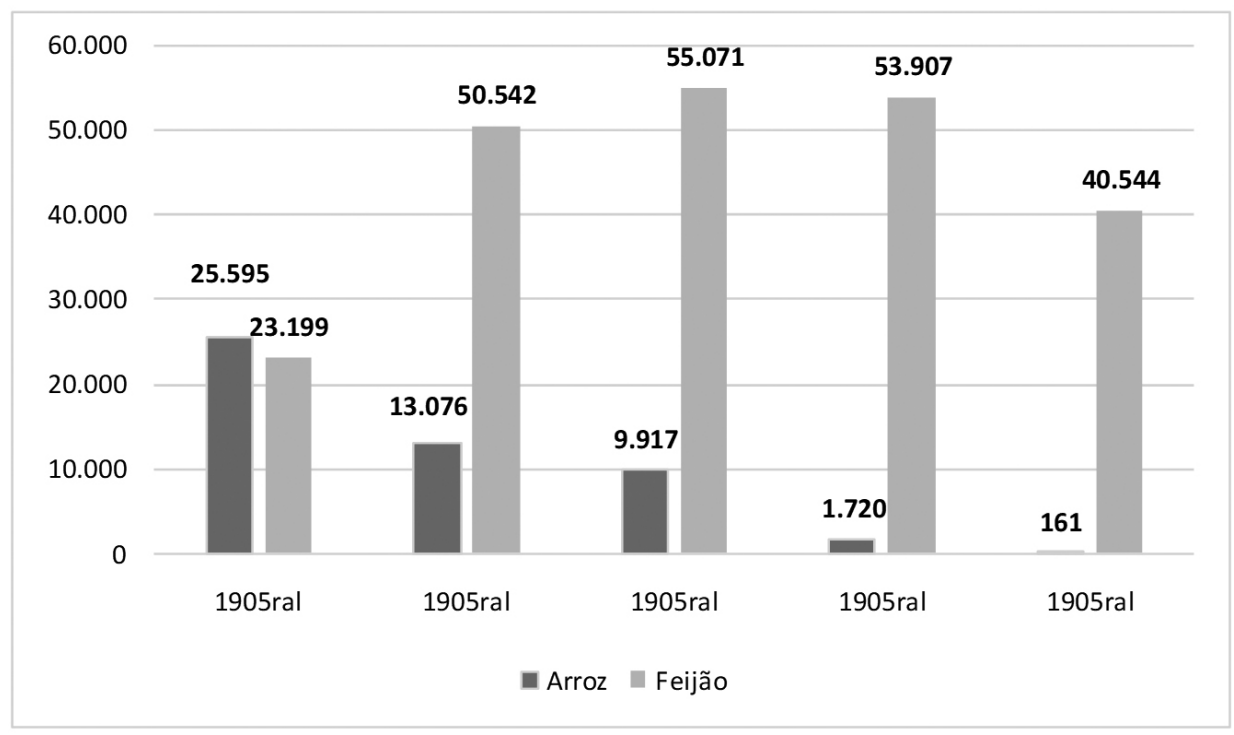

Fonte: Produção Agrícola Municipal (PAM) - IBGE, 2018.

Org: Matos, 2018.

Em Minas Gerais, o acesso à produção da cana-de-açúcar do setor sucroenergético tem ocorrido em terras próprias, fornecedores, arrendamento e parceria agrícola. Os contratos de arrendamento e parceria estão previstos no Estatuto da Terra, Lei n. ${ }^{\circ}$ 4.504, de 1964. 
Conforme o art. 3. ${ }^{\circ}$ desse Estatuto e o Decreto n. ${ }^{\circ}$ 59.566/66 (Brasil, 1966):

Arrendamento é o contrato agrário em que uma pessoa se obriga a ceder a outra, por tempo determinado ou não, o uso e o gozo do imóvel rural, parte ou partes do mesmo, incluindo ou não benfeitorias ou facilidades, com o objetivo de nele ser exercida atividade de exploração agrícola, pecuária, agroindustrial, extrativista ou mista, mediante certa retribuição ou aluguel, observados os limites percentuais da lei.

Sobre a parceria, o Estatuto e o art. $4 .^{\circ}$ do referido Decreto estabelecem que:

Parceria rural trata-se do contrato agrário pelo qual uma pessoa se obriga a ceder a outra, por tempo determinado ou não, o uso específico de imóvel rural, de parte ou partes do mesmo, incluindo, ou não, o uso específico de imóvel rural, de parte ou partes do mesmo, incluindo ou não benfeitorias, outros bens ou facilidades, com o objetivo de nele ser exercida atividade de exploração agrícola, pecuária, agroindustrial, extrativa de matéria-prima, mediante partilha de riscos de caso fortuito e de força maior do empreendimento rural e dos frutos, produtos ou lucros, havidos nas proporçôes que estipularem, observados os limites percentuais da lei.

No contrato de parceria, o proprietário compartilha os riscos e prejuízos da produção porque o valor do contrato não é fixo, como no arrendamento:

É estabelecido que os riscos da atividade devem ser suportados igualmente pelo parceiro-outorgante e pelo parceiro-outorgado, e os lucros serão repartidos conforme proporção previamente estabelecida em contrato, conforme maior ou menor participação na atividade por parte do parceiro-concedente (Almeida e Buainan, 2013, p. 331).

Essas variáveis motivam e incrementam o crescimento das parcerias em substituição ao arrendamento nos contratos para o cultivo de cana-de-açúcar. Marques e Pettersen (1977, p. 37) apontam algumas diferenças entre o contrato de arrendamento e de parceria, 
A princípio, em relação à forma de remuneração pelo uso da terra. No arrendamento, o valor é fixo. Na parceria, é variável, conforme o montante da colheita efetuada. Em segundo lugar, existem entre os parceiros, vínculos societários. O parceiro proprietário pode fiscalizar, em comum com o outorgado, o desenrolar dos trabalhos objeto do contrato; mas, o arrendador, ajustada a relação contratual, se exonera de quaisquer espécies de controle da atividade laboral (Marques e Pettersen, 1977, p. 37).

$\mathrm{O}$ arrendamento e a parceria são formas de se obter renda fundiária, ou renda da terra, de forma que os não proprietários de terra invistam capital para produzir em uma lógica expansionista e de incorporação de novos territórios. O quadro 1 mostra os principais pontos positivos e negativos dos diversos formatos de acesso à cana-de-açúcar para as usinas sucroenergéticas.

Quadro 1: Formas de acesso à cana-de-açúcar pelas usinas

\begin{tabular}{|c|c|c|}
\hline $\begin{array}{c}\text { FORMAS DE } \\
\text { ACESSO }\end{array}$ & VANTAGENS & DESVANTAGENS \\
\hline $\begin{array}{l}\text { Cana própria } \\
\text { em terra } \\
\text { própria }\end{array}$ & $\begin{array}{c}\text { - Forma mais tradicional de acesso } \\
\text { à cana, aliando a propriedade ao } \\
\text { patrimônio da usina } \\
\text { - Fluxo contínuo de matéria-prima } \\
\text { - Valorização imobiliária } \\
\text { - Melhor controle da qualidade do solo } \\
\text { e maior produção } \\
\text { - Facilidade de logística/manutenção } \\
\text { dos acessos }\end{array}$ & $\begin{array}{c}\text { - Restrição de aquisição de terras } \\
\text { por estrangeiros } \\
\text { - Perda do foco da atividade } \\
\text { primária }\end{array}$ \\
\hline $\begin{array}{l}\text { Cana própria } \\
\text { em terra de } \\
\text { terceiros }\end{array}$ & $\begin{array}{c}\text { - Modalidade instituída por meio de } \\
\text { arrendamento ou parceria agrícola } \\
\text { - Garantia de fluxo com baixa } \\
\text { imobilização de capital e investimentos } \\
\text { - Compartilhamento dos riscos de } \\
\text { produção e do preço na modalidade de } \\
\text { parceria } \\
\text { - Rotatividade do solo } \\
\text { - Benefícios fiscais }\end{array}$ & $\begin{array}{c}\text { - Corresponsabilidade no caso de } \\
\text { danos socioambientais } \\
\text { - Usina não se beneficia da } \\
\text { valorização imobiliária } \\
\text { - Sujeição à especulação imobiliária } \\
\text { na modalidade de arrendamento }\end{array}$ \\
\hline
\end{tabular}




\begin{tabular}{|c|c|c|}
\hline $\begin{array}{c}\text { FORMAS DE } \\
\text { ACESSO }\end{array}$ & VANTAGENS & DESVANTAGENS \\
\hline $\begin{array}{c}\text { Cana de } \\
\text { terceiros em } \\
\text { terra própria }\end{array}$ & $\begin{array}{c}\text { - Possibilidade da usina em auferir } \\
\text { renda com o arrendamento da terra e o } \\
\text { posterior processamento da cana } \\
\text { - Custo e risco da produção transferem- } \\
\text { se ao terceiro } \\
\text { - Redução do quadro de funcionários e, } \\
\text { consequentemente, do custo de mão de } \\
\text { obra, maquinário e manutenção }\end{array}$ & $\begin{array}{l}\text { - Ausência de recursos para cultivo } \\
\text { em terra própria acarretou a } \\
\text { possibilidade de arrendamento da } \\
\text { terra a terceiros para posterior venda } \\
\text { à usina da produção de cana } \\
\text { - Desconhecimento ou } \\
\text { inexperiência do produtor sobre } \\
\text { os tratos e cultivo da cana podem } \\
\text { acarretar baixa qualidade do produto } \\
\text { - Insegurança quanto ao fluxo de } \\
\text { matéria-prima } \\
\text { - Ausência de controle sobre } \\
\text { questões trabalhistas } \\
\text { - Riscos de configuração de } \\
\text { terceirização da atividade-fim da } \\
\text { usina }\end{array}$ \\
\hline $\begin{array}{c}\text { Cana de } \\
\text { fornecedores }\end{array}$ & $\begin{array}{l}\text { - Custo e risco da produção transferem- } \\
\text { se ao terceiro } \\
\text { - Redução do quadro de funcionários e, } \\
\text { consequentemente, do custo de mão de } \\
\text { obra, maquinário e manutenção. }\end{array}$ & $\begin{array}{c}\text { - Desconhecimento ou } \\
\text { inexperiência do fornecedor da terra } \\
\text { sobre os tratos e cultivo da cana } \\
\text { podem acarretar baixa qualidade do } \\
\text { produto } \\
\text { - Risco de interrupção do fluxo de } \\
\text { matéria-prima } \\
\text { - Risco de indisponibilidade da } \\
\text { matéria-prima ou elevação no valor } \\
\text { do produto }\end{array}$ \\
\hline
\end{tabular}

Fonte: Postal (2014) e Almeida (2002).

Org.: Andrade (2017).

No Triângulo Mineiro/Alto Paranaíba, as usinas têm investido nos contratos de arrendamento e parceria, chegando algumas a produzirem na quase totalidade desses modelos, visto que tem sido uma opção rentável para a expansão da atividade, já que requer grande quantidade de terra para o cultivo da cana-de-açúcar. Com isso, há uma pressão por parte das usinas sobre os proprietários, porque há a necessidade de ocupar para expandir, especialmente as territorialmente mais próximas a estas (até cem quilômetros em razão da logística, em que se consideram os custos com corte, carregamento e transporte). Outros fatores são extremamente importantes: a) fertilidade do solo; b) relevo plano (para a mecanização); c) abundância hídrica (para irrigação); d) tamanho da propriedade (preferencialmente, acima de 20 hectares); e) vias de acesso (estradas para facilitar o processo produtivo, sobretudo, o escoamento da cana para a usina); 
e f) documentação da propriedade regularizada. Estes influenciam no preço pago por hectare e o período dos contratos, que variam de cinco a dez anos.

Merece atenção o fato de que tanto o valor quanto a duração do contrato são distintas, segundo os elementos citados anteriormente, e ainda, conforme o conhecimento jurídico, informações dos valores pagos a outros proprietários, relação política e resistência do proprietário. As usinas possuem profissionais para recrutar terras/propriedades propicias e fazerem as negociaçóes de contratos.

Ao analisar um contrato de parceria de uma usina localizada na microrregião de Ituiutaba, a partir da efetivação do contrato, observa-se que esta tem livre acesso à propriedade para o processo de produção, estabelecendo relações de domínio e poder,

Durante todo do prazo do Contrato de Parceria, inclusive no caso de prorrogação ou renovação, fica assegurado o livre trânsito da PARCEIRA OUTORGADA, por si ou seus prepostos, no Imóvel, mesmo que contíguas à Área Cultivável, com suas máquinas, veículos e empregados, podendo ainda o acesso à Área Cultivável ser alterado para facilitar o tráfego (Contrato de Parceria Agrícola, 2011).

Consta no contrato que, caso ocorra a venda da propriedade, o comprador tem que cumprir o contrato até o prazo final:

A alienação ou transferência, a qualquer título, do imóvel objeto deste Contrato para quaisquer terceiros, ou a imposição de ônus real sobre o imóvel não poderá servir de escusa a interromper ou prejudicar a vigência e execução deste Contrato, ficando o adquirente ou beneficiário sub-rogado nos direitos e obrigaçóes do PARCEIRO OUTORGANTE, sendo tal adquirente ou beneficiário sub-rogado obrigado a respeitar e a cumprir o presente Contrato até o seu termo final, na forma preconizada pelo artigo 92, parágrafo $5^{\circ}$ do Estatuto da Terra, e no artigo 15 do Decreto n. ${ }^{o}$ 59.566/66 (Contrato de Parceria Agrícola, 2011).

O arrendamento e a parceria das terras para a produção de monoculturas de cana atestam uma situação de vulnerabilidade do território, subordinação 
dos proprietários de terra e relação de poder das usinas. Há um cenário de disputa por terras: proprietários com anseio de continuar produzindo e esforçando-se para sua permanência no espaço rural, e as usinas ansiando apropriar-se desses territórios. Muitos, especialmente os camponeses, se veem "forçados" ou seduzidos com propostas compensadoras para ceder ao arrendamento ou parceira de suas propriedades. Esse cenário tem provocado a reestruturação produtiva dos municípios, com aumento exorbitante da produção de cana, em detrimento da produção tradicional de arroz, feijão, milho, hortaliças, entre outros, contribuindo, dessa forma, para a diminuição da produção de alimentos em nível local, regional e, consequentemente, para a soberania alimentar.

Apesar de as usinas quererem apropriar-se de todas as "terras" de seu interesse para produção da cana, é possível encontrar as resistências, em virtude, sobretudo, dos laços culturais com a propriedade, e também aqueles que resistem porque as propriedades ou parte delas não atendem aos interesses das usinas. Estes encontram-se "ilhados" por canaviais e vivendo os impactos que a monocultura causa no meio ambiente com os desmatamentos, o uso de agrotóxicos, poluição do ar e poeira ocasionada pelo tráfego de carretas que transportam a cana colhida das lavouras até as usinas.

\section{Considerações finais}

No Brasil, a produção dos biocombustíveis também levanta questões sobre os riscos e os efeitos que a expansão das lavouras de cana-de-açúcar traz para a produção de alimentos, para a sociedade e para a biodiversidade dos biomas brasileiros. Os efeitos ambientais, principalmente, em relação aos recursos hídricos e sociais, são evidentes. Então, questiona-se que energia "limpa", é essa? O que significam os dados quantitativos da produção de açúcar, álcool e energia, diante de tantos efeitos negativos e perversos da expansão da cana-de-açúcar para o setor sucroenergético?

O setor sucroenergético produz sob os imperativos do mercado global, incorpora uma racionalidade capitalista nas relações de produção. Pouco se respeitam as "leis" da natureza, criando-se, dessa forma, disputas e conflitos. As disputas nem sempre são caracterizadas por conflitos visíveis, mas da luta pela permanência e pela (re)existência, como é o caso dos camponeses.

Por fim, é preciso desvelar que esse novo cenário produtivo da cana-de-açúcar para atender o setor sucronergético atende efetivamente a uma pro- 
posta do capital. As preocupações com uma matriz energética sustentável, são discursos infindos do governo e de todos os que apoiam esse modelo. Especificamente no que se refere ao Triângulo Mineiro/Alto Paranaíba, considerada uma das principais áreas para a expansão, ainda que se afirme a contribuição dessa monocultura para o crescimento econômico, é mais uma atividade agrícola responsável por inúmeros efeitos sociais, culturais e ambientais em diversas escalas.

\section{Referências}

ALMEIDA, P. J. de e BUAINAN, A. M. “Os contratos de arrendamento e parceria no Brasil”. Revista Direito GV , v. 9, n. 1, pp. 319-244, São Paulo, jan.-jun., 2013.

ANDRADE, M. C. de. Modernização epobreza: a expansão da agroindústria canavieira e seu impacto ecológico e social. São Paulo: UNESP, 1994.

ANDRADE, V. C. S. O novo código florestal e os impactos ambientais no entorno do reservatório de São Simão em consequência da expansão canavieira (dissertação) Universidade Federal de Uberlândia, 2017.

BERNARDES, J. A. et al. (orgs.). Espaço e energia: mudanças no paradigma sucroenergético. Rio de Janeiro: Editora Lamparina, 2013.

BESKOW, P. R. Arrendamento capitalista na agricultura: evolução e situação atual da economia do arroz no Rio Grande do Sul. São Paulo: HUCITEC; Brasília: Conselho Nacional de Desenvolvimento Científico e Tecnológico, 1986.

BOMBARDI, L. M. e GARVEY, B. "Agrotóxicos no agronegócio brasileiro: a sujeira por trás da 'energia limpa'. IV WORSHOP, Goiânia, CD ROM, pp. 29-36, 2016.

BRASIL. "Decreto n. ${ }^{\circ} 59.566 / 1966$ que regulamenta o Estatuto da Terra”. Disponível em: www.planalto.gov.br. Acesso em: 12 fev. 2017.

. "Lei n. ${ }^{\circ}$ 4.504/1964 que dispóe sobre o Estatuto da Terra". Disponível em: www.planalto.gov.br. Acesso em: 12 fev. 2017. 
CAMPOS, N. L. Redes do agronegócio canavieiro: a territorialização do Grupo Tércio Wanderley no Triângulo Mineiro/Alto Paranaíba - MG (dissertação). Universidade Federal de Uberlândia, 2014.

CASTILHO, R. "Região competitiva e circuito espacial produtivo: a expansão do setor sucro-alcooleiro no Brasil”. Anais do VII ENCONTRO NACIONAL DA ANPEGE, Curitiba, 2009.

e FREDERICO, S. "Dinâmica regional e globalização: espaços competitivos agrícolas no território brasileiro”. Mercator, v. 9, n. 18, p. 1.726, Fortaleza, 2010.

ELIAS, D. "Regiões produtivas do agronegócio: notas teóricas e metodológicas". In: BERNARDES, J. A. et al. (orgs.). Espaço e energia: mudanças no setor sucroenergético. Rio de Janeiro: Lamparina, 2013, pp. 201-20.

FAGUNDES, F. N. Setor sucroalcooleiro: relações contratuais e determinantes do território (dissertação). Universidade Estadual Paulista, 2016.

GOES, T. et al. "Setor sucroalcooleiro no Brasil: situação atual e perspectivas". Revista Política Agrícola, n. 2, pp. 39-52, Brasília, abr.- maio-jun. 2008.

HARVEY, D. A produção capitalista do espaço. Trad. Carlos Szlak. São Paulo: Annablume, 2006.

IBGE - Instituto Brasileiro de Geografia e Estatística. Produção municipal de Minas Gerais 1990/2016. Disponível em: http://www.ibge.gov.br, 2015. Acesso em: 15 mar. 2017.

MARQUES, N. e PETTERSEN, A. Uso e posse temporária da terra: arrendamento e parceria. São Paulo: Pró-livro, 1977.

MATOS, P. F. As tramas do agronegócio nas "terras" do Sudeste Goiano (tese). Universidade Federal de Uberlândia, 2011.

OLIVEIRA, A. U. de. Modo de produção capitalista, agricultura e reforma agrária. São Paulo: FFLCH, 2007.

POSTAL, A. C. M. Acesso à cana-de-açúcar na expansão sucroenergética brasileira do pós-2000: o caso de Goiás (dissertação). Universidade Estadual de Campinas, 2014. 
SANTOS, M. A natureza do espaço: técnica e tempo, razão e emoção. 4 ed. São Paulo: HUCITEC, 2006.

e SILVEIRA, M. L. O Brasil: território e sociedade no início do século XXI. Rio de Janeiro: Record, 2001.

SIAMIG/SINDAÇÚCAR - Sindicato das Indústrias Sucroenergéticas de Minas Gerais. Disponível em: http://www.siamig.com.br/. Acesso em: jan. 2016.

THOMAZ JUNIOR, A. A. Por trás dos canaviais os nós da cana: a relação capital x trabalho e o movimento sindical dos trabalhadores na agroindistria canavieira paulista. São Paulo: Anablume/FAPESP, 2002. 


\section{Na trilha das reservas particulares do patrimônio natural (RPPN): novas interfaces paisagísticas?}

Elton Simões Gonçalves Glaucio José Marafon

\section{Introdução}

Atualmente, inúmeras funções atinentes à paisagem rural transcendem o setor agropecuário e reforçam uma expressiva e criativa interação campo-cidade não somente restrita à provisão de alimentos, mas também voltada para a oferta de variados serviços, dentre os quais vale aqui destacar: o cuidado e a manutenção de recursos naturais; a organização de espaços para descanso e lazer; e a revalorização de raízes histórico-culturais associadas a releituras turísticas do espaço rural (Marafon, 2010).

No continente europeu, esse cenário já vem se desenhando desde meados dos anos 1970. Segundo Kayser (1990 apud Carneiro, 2012, p. 25),

a dinâmica do mundo rural não caberia mais na afirmação da tendência ao seu esvaziamento social, econômico e cultural. Ao contrário, um sopro de vida é sentido, o que permitiu falar em 'renascimento rural', renascimento esse que não se identifica à modernização do rural nos padrões da cidade, mas na constituição de novas formas de sociabilidade e de relaçôes sociais sustentadas numa rede complexa de atores que não pode mais ser compreendida pura e simplesmente como um processo de urbanização que se encaminharia na direção da homogeneização espacial e social entre campo e cidade. 
Tal fenômeno, na ótica do autor, "nega tanto o fim do mundo rural como o da dualidade campo-cidade, previstos pelo modelo da modernização, ainda que observemos uma aproximação entre os padrões de vida da população rural e urbana" (Kayser, 1990 apud Carneiro, 2012, p. 25). A observação do autor citado reacende a atenção, por parte da geografia, quanto à ponderação da ideia de que os efeitos ubíquos do processo de urbanização no campo levariam à supressão generalizada da diversidade sociocultural e paisagística dos espaços rurais. De fato, é inegável a capilaridade "urbanizante" no campo ao longo do tempo, mas a assimilação socioespacial de tal fenômeno é seletiva e estratificada em virtude da atuação de diferentes "camadas" territoriais, a partir das quais diferentes ruralidades emergem, reivindicam e sofisticam novos significados e ordenamentos.

São, portanto, quadros geográficos que demandam narrativas específicas para tal. Segundo Bicalho (2014, pp. 13-4), "mudanças de função, forma e processos correlacionados são centrais às questões do espaço rural contemporâneo, direcionando a dinâmica espacial e atividades que se expressam espacialmente no uso da terra e sistemas de exploração". Conforme afirma a autora, novas relações interescalares, novos interesses e atores se refletem em novos ordenamentos territoriais, nas formas espaciais e funções rurais, requerendo novas matrizes explicativas da dinâmica do espaço rural.

O crescimento de atividades não agrícolas no espaço rural brasileiro catalisa particularidades espaciais que merecem atenção investigativa da comunidade geográfica. De acordo com Graziano da Silva et al. (2002, p. 39), "a partir de meados dos anos 1980, assistimos ao surgimento de uma nova conformação do meio rural brasileiro, a exemplo do que já ocorre há tempos nos países desenvolvidos". Esse "novo rural" a que o autor faz referência é composto basicamente de três grandes grupos de atividades: uma agropecuária moderna, baseada em commodities e intimamente ligada às agroindústrias; um conjunto de atividades não agrícolas, ligadas à moradia, ao lazer e a várias atividades industriais e de prestação de serviços; e um conjunto de "novas" atividades agropecuárias, impulsionadas por nichos especiais de mercados.

O tema central do presente artigo, a proliferação de unidades de conservação privadas no espaço rural demandantes de novas representações paisagísticas, parece se associar aos segundo e terceiro grupos citados anteriormente. Defendemos que o fenômeno em questão é acompanhado a priori de uma dinâmica imobiliária que se caracteriza pela crescente demanda de atores citadinos 
de médio a alto poder aquisitivo à procura de segundas residências (casas de campo e de veraneio, chácaras e sítios) consorciadas ou não com projetos agroecológicos, os quais incorporam a funcionalidade e a integridade de componentes ecossistêmicos como variáveis de valoração paisagística. A mobilização territorial desses atores citadinos produz novos discursos e significados que, paradoxalmente, promovem uma revalorização qualitativa e temática do espaço rural. Wanderley (2000 apud Carneiro, 2012, p. 25), nesse sentido, assinala a "permanência das diferenças espaciais e sociais contextualizadas por processos históricos de reelaboração contínua da dualidade campo-cidade, engendrantes de novas ruralidades".

Para Graziano da Silva (1996), "o crescimento das atividades não agrícolas é uma decorrência da ampliação do mercado de trabalho urbano para as áreas rurais, sobretudo as mais próximas das grandes cidades". Cabe ressaltar os "novos tipos de ocupações", estimulados pela exploração do turismo e pela transformação dos espaços rurais em áreas de lazer. Encontram-se aí, de acordo com o autor, "as principais alternativas de trabalho para os jovens filhos de agricultores (jardineiros, pedreiros, caseiros, empregadas domésticas, entre outras), constituindo-se uma das formas de pluriatividade no campo" (Graziano da Silva, 1996 apud Carneiro, 2012, p. 29).

Entendida aqui como uma forma de ruralidade, a lógica espacial dos outsiders urbanos e as relaçóes por eles tecidas no interior dos espaços rurais inauguram novos (re)arranjos paisagísticos que têm nas Reservas Particulares do Patrimônio Natural (RPPN) alguns de seus componentes. De acordo com Flexor e Gaviria (2003, pp. 74-5), “a crescente difusão da problemática ambiental na sociedade brasileira contribui para a valorização do mundo rural e modifica a percepção social do papel da agricultura". Isso tem induzido uma nova demanda social por bens e serviços ambientais e de lazer, tais como ecoturismo, paisagens "naturais", alimentos e artefatos artesanais. Tal procura, oriunda principalmente de moradores de grandes centros urbanos, constitui-se como uma importante variável de reestruturação rural, sobretudo em áreas mais próximas de grandes metrópoles.

A divulgação e os esclarecimentos a proprietários interessados sobre as vantagens e desvantagens em criar uma RPPN é resultado de sobreposições territoriais resultantes de uma trama institucional da qual participam órgãos ambientais das três instâncias federativas, Organizações Não Governamentais nacionais e internacionais e Associações de Proprietários de RPPN em âmbito estadual. Para 
Coelho et al. (2009, p. 76), “as unidades de conservação quase sempre são vistas como objetos dados, áreas naturais, e não como objetos criados (concebidos, inventados, disputados)". O contexto de criação dessas arquiteturas espaciais é o que revela a riqueza de relações sociais territorializadas, definidoras do que convém chamar de emergentes padrões paisagísticos. Ainda de acordo com os autores, "como objeto de investigação em construção, elas requerem que sejam reveladas as relações entre grupos sociais (tradicionais ou não) e recursos, bem como os processos de mudanças sociais, ambientais e territoriais." Nesse sentido, o artigo em questão tem como objetivo analisar o papel das RPPN como potenciais vetores sintomáticos de reestruturação socioespacial e de proto-iniciativas de desenvolvimento territorial no espaço rural em associação às dinâmicas territoriais e institucionais vigentes.

\section{RPPN: capilaridade espacial e desenvolvimento rural?}

O crescimento do número de unidades de conservação solicitadas voluntariamente por proprietários rurais está diretamente relacionado com a maior permeabilidade retórica da questão ambiental em nível global e nacional e converge, necessariamente, para debates em torno da noção de desenvolvimento. Destacamos de antemão que não há uma única e ideal política de desenvolvimento rural, dado que as estruturas políticas, institucionais, econômicas e sociais variam em diferentes regiões, países e continentes. No entanto, reconhece-se que o projeto de desenvolvimento rural adotado no Brasil priorizou a expansão e a consolidação de apenas um segmento, o agronegócio de cunho produtivista, tendo alcançado resultados positivos, sobretudo, em relação ao aumento da produtividade e à geração de divisas via exportação em mercados globais.

No entanto, os custos sociais e ambientais inerentes ao referido modelo suscitam inúmeras críticas e o surgimento de vindouras e producentes contracorrentes. No contexto nacional, tomaram forma, nos últimos vinte anos, variadas alternativas experimentais de abrangência mais local, que ao longo do tempo passaram a se articular em redes, a partir das quais, com base em planos de manejo revistos sob a ótica da ecologia e áreas afins, demarcaram nichos potenciais e incentivaram e adoção de agrossistemas em interação e semelhança com os estágios naturais de sucessão ecológica. 
Essa recente virada qualitativa do papel da agricultura e do campo no Brasil, ainda que de abrangência pontual, mas em crescente expansão, não é um fenômeno desconectado de antecedentes temporais e multiescalares. Segundo Silva (2014, p. 122):

A partir dos anos de 1970, as discussōes sobre a Ecologia e o Meio Ambiente ganharam a cena internacional, a partir de fóruns e conferências que foram difundindo ideias e perspectivas que foram modificando a forma como as temáticas ecológico-ambientais foram adentrando as estratégias de gestão dos territórios, e como as políticas públicas podiam somá-las aos seus projetos institucionais e de modernização.

Ainda de acordo com o autor, "as conjunturas advindas daquele período trouxeram para a sociedade civil novos discursos em escalas diversas, em que as consequências socioespaciais da predação ecológico-ambiental se tornaram menos compreensíveis" (Silva, 2014, p. 121). Tais retóricas serviram de base para mudanças nas políticas implementadas pelos gestores que ordenam os territórios e nos padrões de territorialidade mais locais dos atores sociais que vivenciam o real padrão socioambiental nos lugares.

À matriz discursiva do desenvolvimento rural sustentável, ganhou impulso a inclusão do componente "territorial" na perspectiva de reforçar a importância do engajamento dos atores sociais. $\mathrm{O}$ aditivo em questão tem como objetivo principal "a geração de relaçôes de cooperação positivas e transformadoras do tecido social, ou seja, a composição de territorialidades múltiplas e definidoras de relações sociais mais inclusivas e participativas" (Rocha et al., 2004).

Nesse sentido, à luz das novas ruralidades que emergem, mostra-se igualmente importante reconhecer o avanço das atividades não agrícolas no campo em concomitância com a agropecuária. De acordo com Maluf (2002 apud Costa-Alves e Guimarães, 2009, p. 51):

a importância de promover o debate sobre o tema da multifuncionalidade da agricultura no Brasil justifica-se pela crescente atenção destinada às questôes como o caráter pluriativo das famílias rurais em função do peso das atividades não agrícolas no âmbito rural; o papel da agricultura e demais atividades 
rurais na manutenção ou na criação de novos empregos; o processamento, a transformação e a venda direta de produtos agrícolas de qualidade; o agroturismo; a proteção ao meio ambiente e da biodiversidade; as preocupações ligadas à segurança alimentar; e, em menor escala, à produção-manutenção da paisagem rural.

Veremos na próxima seção deste capítulo que a criação de uma RPPN é um ato voluntário por parte do proprietário rural, normalmente assistido por associações, órgãos ambientais e organizações não governamentais. No entanto, de acordo com a capilaridade relacional dos atores que empreendem o referido modelo de conservação, o número de interessados pode aumentar, assim como potenciais simbioses e sinergias espaciais sugerem novas formas econômicas embebidas por exigências paisagísticas específicas e engendradas por dinâmicas territoriais inéditas.

Conceitos e projetos como corredores ecológicos, agroecossistemas, conectividade entre fragmentos florestais, interações entre manchas de uso e cobertura do solo na "matriz rural", zonas de amortecimento para unidades de conservação públicas estão imbrincados e, se superpostos, resultam de mobilizações sociais inéditas. Nesse sentido, Pecqueur (2005, p. 12) afirma que o "desenvolvimento territorial designa todo processo de mobilização dos atores que leve à elaboração de uma estratégia de adaptação aos limites externos, na base de uma identificação coletiva com uma cultura e um território". Para o autor, "essa construção só pode ser concebida como uma dinâmica e, portanto, inserida no tempo. O desenvolvimento territorial visa, portanto, revelar recursos inéditos, que constituem uma inovação.”

Assim, de acordo com Silva (2014, p. 131), "há que se observar o papel da política territorial e do entrecruzamento das legislações empenhadas pelos poderes públicos e agentes privados instituídos e instituintes”. Portanto, a saudável estabilidade e sustentabilidade rural, à luz de novas funcionalidades circundantes à delimitação de uma RPPN, vão depender da articulação interescalar, horizontal e vertical, entre os agentes de gestão e os atores sociais organizados em rede, nas suas respectivas fontes legítimas de institucionalidade e campos de ação. 


\title{
RPPN: panorama, dinâmicas institucionais e potenciais arranjos paisagísticos
}

A Geografia compreende um campo de estudo cujo objetivo consiste em analisar, de forma integrada, o peso variável - temporal e espacial - das dimensões sociais, econômicas, políticas, ambientais e culturais, definidoras de inúmeros arranjos espaciais. A busca de um "porquê" para o "onde" - bordão há muito conhecido - constitui um rico exercício investigativo dedicado à diferenciação, estruturação e explicação da diversidade espacial contemporânea, impregnada de dinâmicas territoriais e temporalidades múltiplas. Nesse sentido, concordamos com Silva (2014, p. 124) ao afirmar que a Geografia é "uma ciência do pensar políticas territoriais no Brasil e no mundo".

Ações convergentes/divergentes correspondem a intencionalidades sinérgicas/excludentes que repercutem em formações socioespaciais particulares. Podemos considerar, então, a variabilidade na escala de ação dos sujeitos produtores do espaço como um fator estruturante de uma ordem espacial particular, a qual se revela como a síntese da sobreposição territorial de relações de poder assimétricas, configurando assim uma miríade de processos sociais obrigatoriamente espacializados e cristalizados de forma mais evidente em mosaicos paisagísticos.

Uma unidade de conservação é um componente espacial e uma resultante de uma dada trama territorial. Segundo Coelho et al. (2009, p. 76),

\begin{abstract}
muitos pesquisadores tendem cada vez mais a examinar as unidades de conservação e seus contextos, considerando a configuração territorial e o conjunto de relaçôes que definem territorialidades em um dado momento e em determinado espaço. Analisam ainda o arranjo institucional e os regimes de propriedades que fazem os territórios existirem. Assim, as unidades de conservação são, antes de tudo, examinadas como territórios de exercício de poder habitados por grupos sociais com identidades territoriais, símbolos e marcas distintivas, já existentes ou (re)inventadas.
\end{abstract}

Ainda de acordo com os autores, as unidades de conservação podem ser interpretadas "como reservas territoriais estratégicas, criações que se destinam a proteger/poupar recursos ou a garantir a reprodução de recursos renováveis, 
de proteção institucional e apoio governamental com vistas ao futuro" (Coelho et al., 2009, p. 77).

As estratégias para a conservação da natureza em terrenos privados no Brasil se agrupam em dois mecanismos: obrigatório e voluntário. Entre os esquemas obrigatórios, encontram-se aqueles estabelecidos no Código Florestal Brasileiro de 1934, que foi atualizado pela última vez em 2012, e aqueles incluídos na lei que estabelece o Sistema Nacional de Unidades de Conservação (SNUC). O principal mecanismo voluntário é a criação de Reservas Particulares do Patrimônio Natural.

O processo de criação de uma RPPN se diferencia do contexto de criação das demais unidades de conservação públicas por resultar da livre vontade do proprietário rural pelo reconhecimento dessa modalidade de área protegida.

De acordo com Souza e Corte (2009, p. 12),

as áreas particulares protegidas no Brasil já estavam previstas desde o Código Florestal de 1934. Então chamadas de Florestas Protetoras, essas áreas permaneciam em posse e domínio do proprietário e eram inalienáveis. Com o Código Florestal de 1965, a categoria 'Florestas Protetoras' desapareceu, mas ainda permaneceu a possibilidade de preservação de forma perpétua de remanescentes naturais em propriedades privadas.

Outras iniciativas de conservação em terras privadas, entretanto, ocorreram nesse intervalo temporal. Segundo Bensusan (2006, pp. 150-1),

em 1977, o Instituto Brasileiro de Desenvolvimento Florestal (IBDF) editou a portaria n. ${ }^{\circ} 327-P$, criando os Refúgios de Animais Nativos. Em 1988, essa portaria foi substituída pela de n. ${ }^{\circ} 217$, criando as Reservas de Flora e Fauna. Algumas dezenas de refúgios e reservas foram estabelecidas durante esses anos, mesmo sem nenhum incentivo governamental. Em 1987, a Fundação Pró-Natureza, uma Organização Não Governamental sediada em Brasília, instituiu um programa para a criação de 'Santuários de Vida Silvestre', uma categoria que não constava no sistema de unidades de conservação do país.

Ao longo do século XX, outras organizações ambientalistas também apoiaram proprietários em preservar suas florestas na forma de investimentos 
diretos, "canalizando recursos estrangeiros para tal fim ou comprando terras" (Bensusan, 2006, p. 151).

Em 1990, com o intuito de regulamentar o art. 6. ${ }^{\circ}$ do Código Florestal, foi promulgado o Decreto n. ${ }^{\circ}$ 98.914, criando a figura da Reserva Particular do Patrimônio Natural, ainda não formalmente reconhecida como uma categoria de unidade de conservação com status equivalente ao das demais unidades públicas. Ainda que significativa, a área total protegida por RPPN em nível nacional é pequena diante do potencial de conservação de biodiversidade em terras privadas. Conforme aponta Costa (2006, p. 18),

o Decreto n. ${ }^{\circ}$ 98.914, de 1990, foi revogado pelo Decreto n..$^{\circ} 1.922$, de 5 de junho de 1996. O novo decreto trouxe modificaçōes importantes, destacando-se o caráter perpétuo da averbação voluntária, já que pelo instrumento anterior a área poderia perder o título de RPPN caso ocorressem modificaçôes relevantes nas condições ambientais que justificaram a sua proteção. Além disso, o Decreto n. ${ }^{\circ} 1.922$ definiu claramente as restrições de uso e os benefícios conferidos aos proprietários dessas reservas.

\section{Segundo o referido Decreto,}

a RPPN é uma área de domínio privado a ser especialmente protegida, por iniciativa de seu proprietário, mediante o reconhecimento do Poder Público, por ser considerada de relevante importância, pela sua biodiversidade, ou pelo seu aspecto paisagístico, ou ainda por suas características ambientais que justifiquem ações de recuperação (Bensusan, 2006, p. 151).

“Com a Lei n. ${ }^{\circ}$ 9.985, de 18 de julho de 2000, que criou o Sistema Nacional de Unidades de Conservação (SNUC), as RPPNs foram finalmente reconhecidas como unidades de conservação" (Costa, 2006, p. 18). Em seu artigo 21:
A Reserva Particular do Patrimônio Natural é uma área privada, gravada com perpetuidade, com o objetivo de conservar a diversidade biológica.
$\$ 1 .^{\circ}$ - O gravame de que trata este artigo constará de termo de compromisso assinado perante o órgão ambiental, que verificará a existência de interesse público, e será averbado à margem da inscrição no Registro Público de Imóveis. 
$\$ 2 .^{\circ}$ - Só poderá ser permitida, na Reserva Particular do Patrimônio Natural, conforme se dispuser em regulamento:

I - a pesquisa científica;

II - a visitação com objetivos turísticos, recreativos e educacionais;

III - (VETADO)

$\$ 3 .^{\circ}$ - Os órgãos integrantes do SNUC, sempre que possível e oportuno, prestarão orientação técnica e científica ao proprietário de Reserva Particular do Patrimônio Natural para a elaboração de um Plano de Manejo e de Gestão da unidade (Brasil, 2000).

Conforme observado, a orientação regulatória para esses emergentes componentes territoriais visa à preservação da diversidade biológica, das paisagens notáveis e, subsidiariamente, sítios que apresentem elevado valor histórico, arqueológico, paleontológico e espeleológico. Há, nesse sentido, marcantes restrições de uso.

Segundo o Decreto n. ${ }^{\circ} 5.746 / 2006$, a delimitação de uma RPPN pode sobrepor áreas de reserva legal (ARL) e de preservação permanente (APP), ou seja, o proprietário poderá converter em uma unidade de conservação uma extensão de área que já não poderia ser utilizada sem algum tipo de regulação especial. Vale ressaltar que, uma vez criada a RPPN, não é possível mudar o status da área, nem poderá esta ser usada como parte da penhora para financiamentos futuros. Além disso, os proprietários estão sujeitos a inspeções periódicas do órgão ambiental responsável pelo reconhecimento formal, assim como já ocorre nas demais áreas protegidas integrantes do SNUC. Toda propriedade rural que tenha aderido ao modelo RPPN possui uma sinalização específica, conforme podemos observar na figura 1 , a seguir. 
Foto 1: Sinalização obrigatória na entrada de propriedade rural detentora de RPPN em Nova Friburgo, RJ

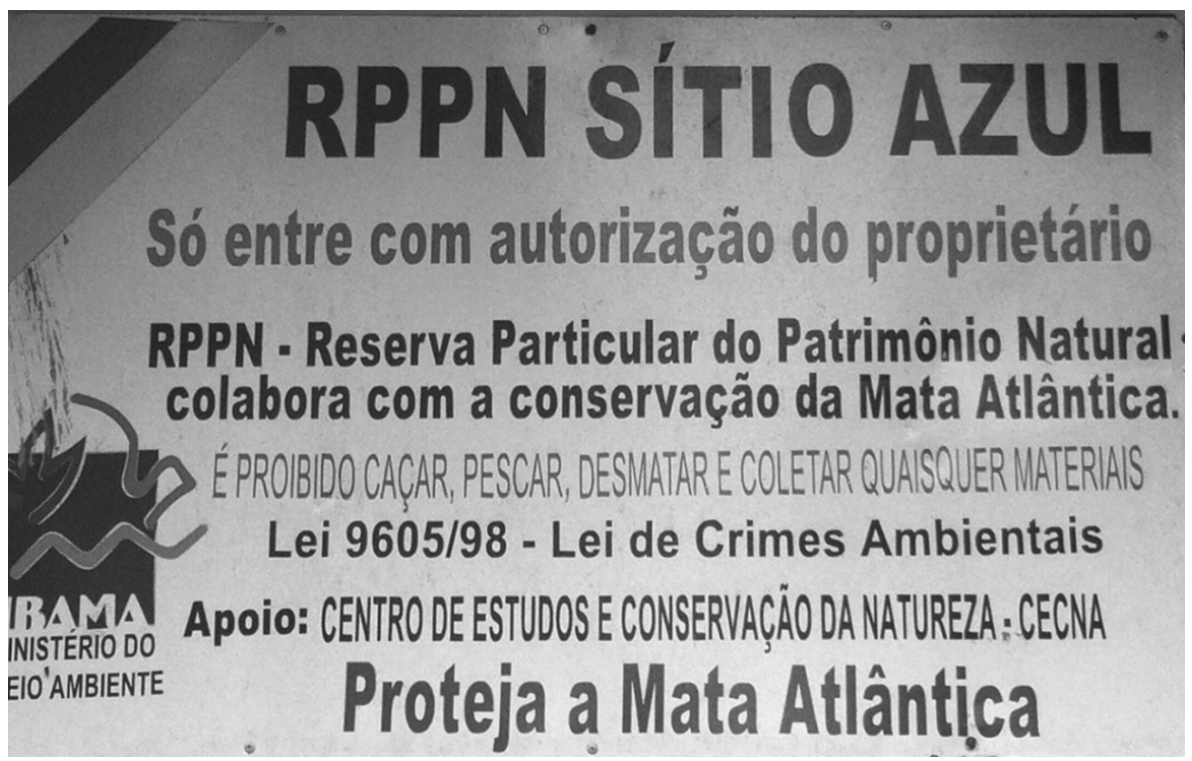

Fonte: Acervo do autor.

O que sugere funcionar como um fator de compensação à área inutilizada é a perspectiva de reorientação funcional da propriedade em torno de atividades ligadas ao turismo rural, em especial, a modalidade do ecoturismo. O mapa 1, disponível adiante, é representativo de uma propriedade rural localizada no município de Silva Jardim, estado do Rio de Janeiro, e representa o arranjo normativo e turístico esperado.

É importante situar o modelo RPPN como um tipo de parceria público- privada. As compensações de ordem tributária e financeira disponíveis aos atores sociais interessados são as seguintes:

(1) dedução do Imposto Territorial Rural (ITR) sobre a área destinada à criação da referida unidade de conservação; (2) prioridade na análise de concessão de recursos para projetos necessários à implantação e gestão das RPPN reconhecidas ou certificadas junto ao Fundo Nacional do Meio Ambiente (FNMA); (3) preferência na análise de concessão de crédito agrícola por instituiçōes oficiais (Bensusan, 2006, p. 153). 
$\mathrm{Na}$ conjuntura histórico-social e no cenário institucional atuais, identificamos um expressivo impulso em favor da criação de unidades de conservação em propriedades rurais. Uma vez que a maior parte das áreas que deveriam ou poderiam ser preservadas está nas mãos de particulares, o poder público seria obrigado a adquiri-las mediante desapropriação e, em seguida, proceder com subsequente indenização, para a qual, em geral, não há recursos (Bensusan, 2006).

Mapa 1: Exemplo de propriedade rural com RPPN delimitada

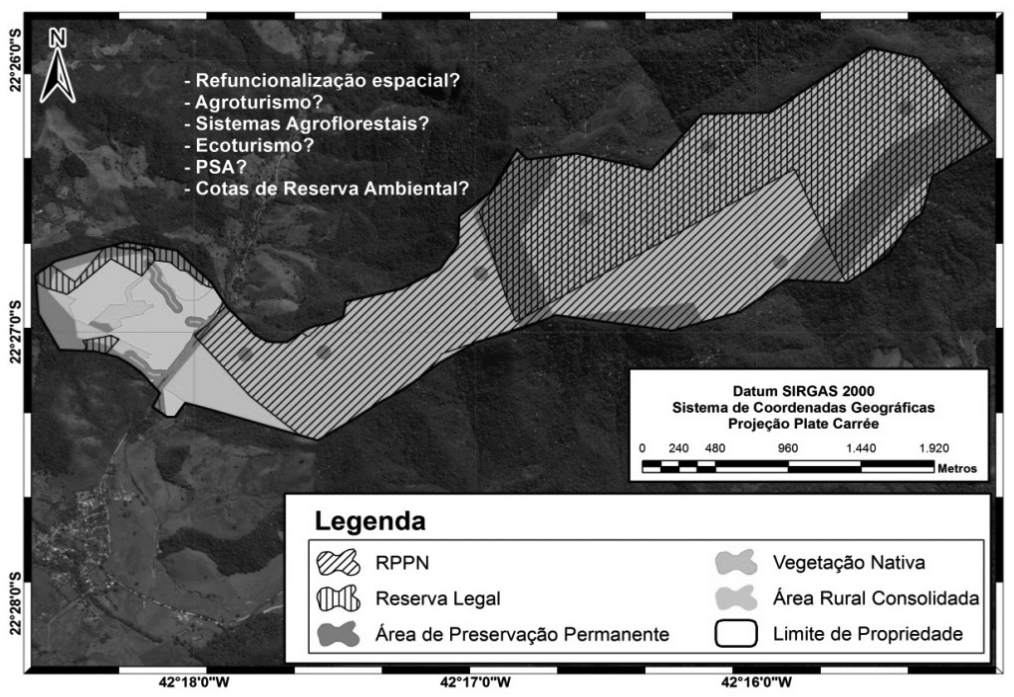

Fonte: Sistema Informatizado de Monitoria de RPPN (SIMRPPN) e Sistema Nacional de Cadastro Ambiental Rural (SICAR) (NEGEF, 2018).

Segundo dados disponíveis no portal da Confederação Nacional de Reservas Particulares do Patrimônio Natural (CNRPPN), ${ }^{7}$ o território nacional conta, atualmente, com 1.485 RPPN, as quais ocupam um total de 772.150,13 hectares. Desse total, conforme aponta o gráfico 1, 69\% pertencem a pessoas físicas, enquanto $25 \%$ pertencem a pessoas jurídicas. A participação minoritária do terceiro setor, 5\%, sugere a atuação mais indireta de ONGs como agentes mais incentivadores do modelo privado de conservação.

7 Disponível em: https://www.rppn.org.br/indicadores-de-rppns. 
Os órgãos ambientais das três instâncias federativas - Instituto Chico Mendes de Conservação da Biodiversidade (ICMBio), institutos estaduais e secretarias municipais de meio ambiente - vêm incentivando adesões ao modelo privado de preservação da biodiversidade, ainda que, no atual quadro de descentralização da gestão ambiental, tenha sido observada uma melhor inserção das esferas estaduais e federal, mas, em menor patamar, as ações dos municípios na condução dos trâmites de reconhecimento de uma RPPN. O gráfico 2 evidencia o cenário em questão.

Gráfico 1: Perfil de proprietários de RPPN em nível nacional

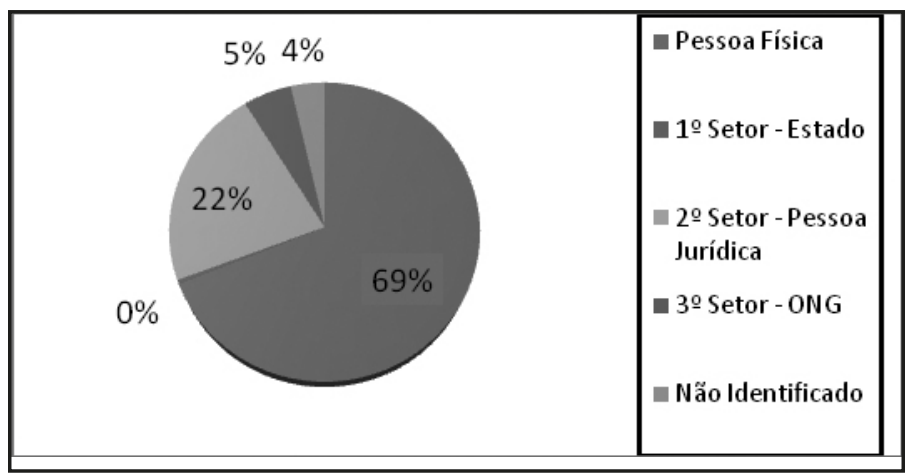

Fonte: Confederação Nacional de Reservas Particulares do Patrimônio Natural (CNRPPN) (NEGEF, 2018).

Gráfico 2: Reconhecimento de RPPN por entes federativos

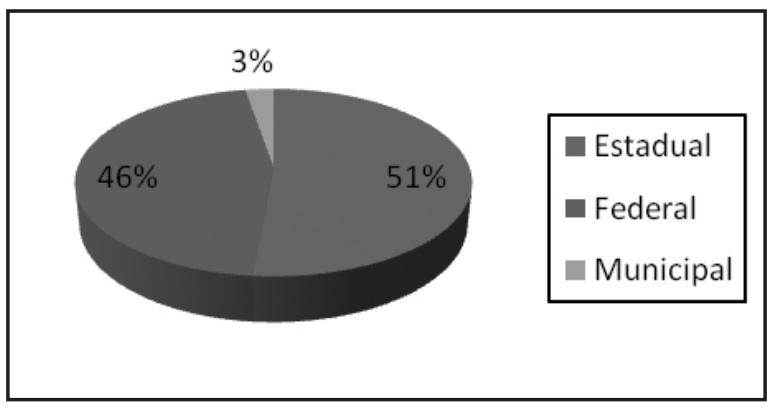

Fonte: Confederação Nacional de Reservas Particulares do Patrimônio Natural (CNRPPN) (NEGEF, 2018). 
O gráfico 3, disposto mais adiante, destaca, por sua vez, a participação percentual das regiões brasileiras quanto à quantidade de unidades de conservação privadas. Percebe-se que as regiões sudeste e sul respondem por mais de $69 \%$ da quantidade de RPPN em nível nacional. A conjugar a vanguarda e atuação institucional mais efetiva dos órgãos ambientais na divulgação do modelo de conservação ambiental em questão com o peso demográfico, melhores condições de infraestrutura de comunicação e acessibilidade nos espaços rurais, os efeitos de polarização urbana nos estados mais populosos acrescidos de sofisticados movimentos contraurbanizantes protagonizados por profissionais liberais com conhecimentos em ecologia ou ciências afins, os emergentes mercados imobiliários em busca de chácaras, sítios e residências de veraneio, justificam, portanto, a predominância de pessoas físicas responsáveis pela administração das RPPN.

Gráfico 3: Participação percentual de RPPN por regiões em nível nacional

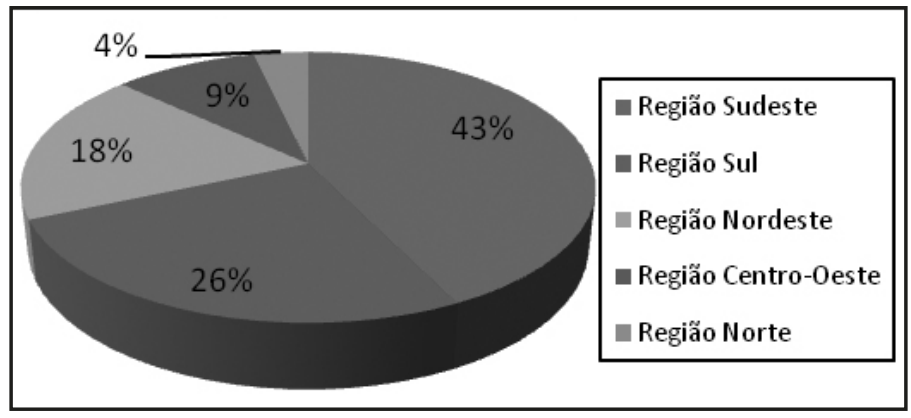

Fonte: Confederação Nacional de Reservas Particulares do Patrimônio Natural (CNRPPN) (NEGEF, 2018).

O mapa 2, a seguir, representa a distribuição em quantidade dessas reservas por unidade federativa. Os cinco estados com maior número de RPPN em nível nacional são, respectivamente, Minas Gerais, Paraná, Rio de Janeiro, Bahia e São Paulo. 
Mapa 2: Quantidade de RPPN por unidade federativa

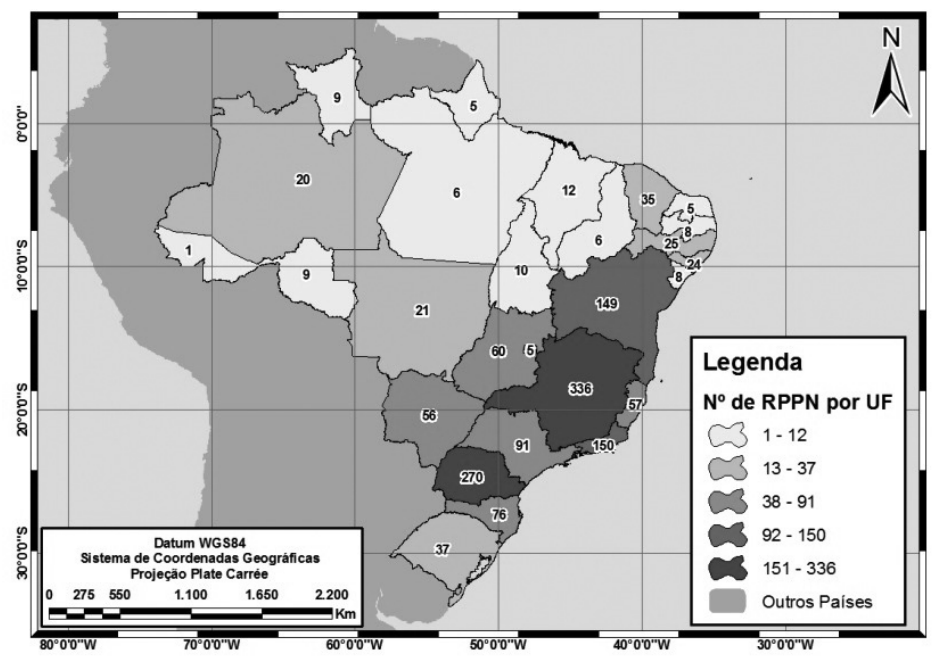

Fonte: Nacional de Reservas Particulares do Patrimônio Natural (CNRPPN) (NEGEF, 2018).

No que tange ao total de área protegida em RPPN por unidade da federação, os estados de Mato Grosso e Mato Grosso do Sul estão nas primeiras posiçôes, uma vez que a dimensão dos módulos fiscais nesses e em outros estados menos populosos são significativamente maiores do que nas áreas com maior peso demográfico. $\mathrm{O}$ mapa 3 , a seguir, destaca tal particularidade se comparada com o mapa anterior. 
Mapa 3: Total de área de RPPN por unidade federativa

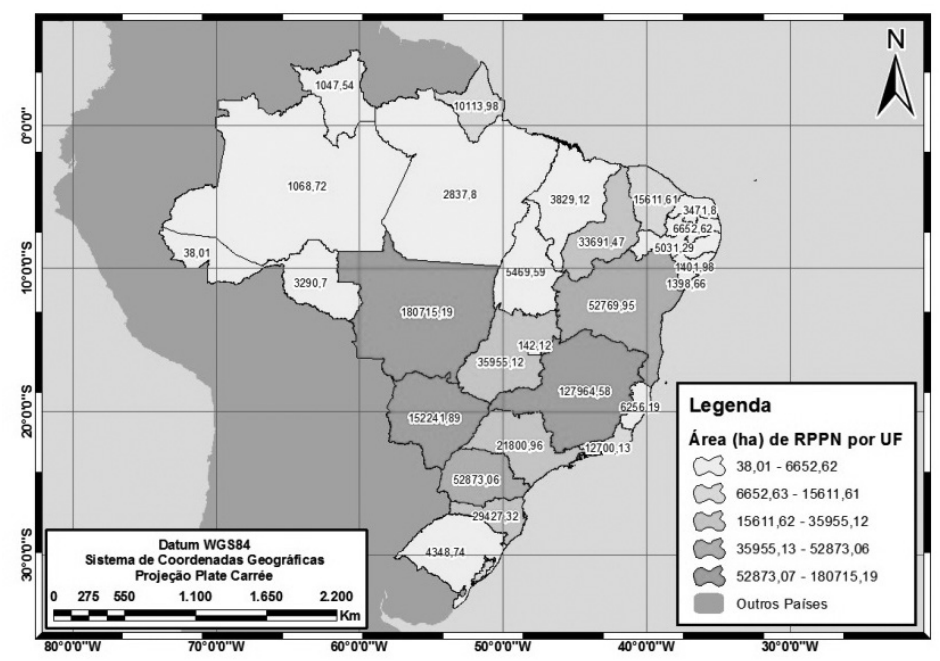

Fonte: Nacional de Reservas Particulares do Patrimônio Natural (CNRPPN) (NEGEF, 2018).

Entretanto, estados como Minas Gerais, Paraná e Bahia sobressaem em termos de área e quantidade. Um aspecto relevante que justifica a maior concentração de RPPN nos estados e regiões citados, a incluir também o estado do Rio de Janeiro, refere-se à atuação de Organizações Não Governamentais, como Conservação Internacional Brasil, SOS Mata Atlântica e The Nature Conservancy, na condução de programas de incentivo às RPPN, especificamente direcionados ao hotspot ambiental do bioma Mata Atlântica, conforme é possível analisar no mapa 4, a seguir. 
Mapa 4: Distribuição espacial de RPPN por biomas brasileiros

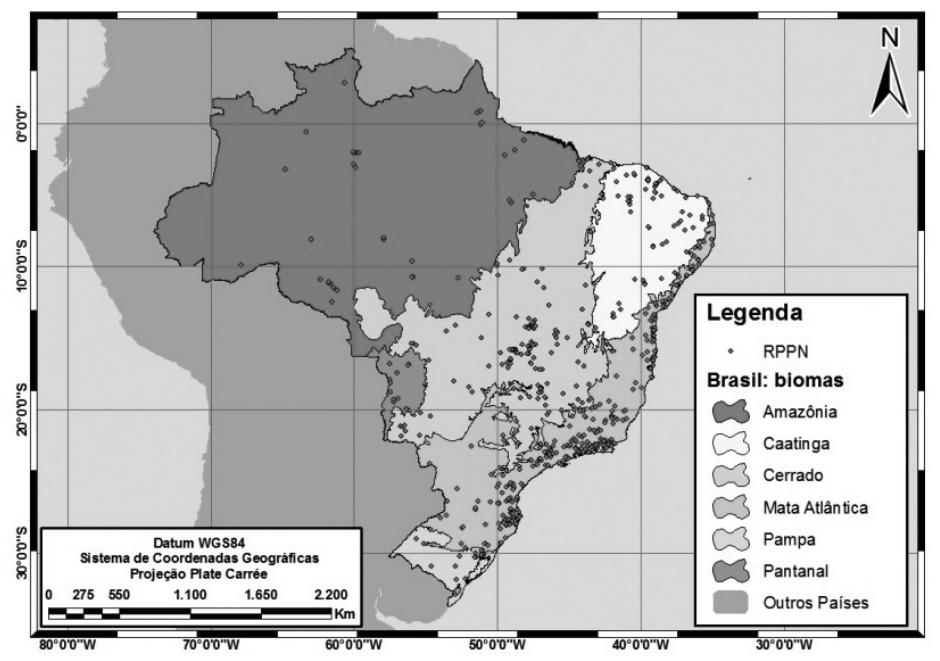

Fonte: Sistema Informatizado de Monitoria de RPPN (SIMRPPN) e Ministério do Meio Ambiente (NEGEF, 2018).

Apesar do pequeno percentual de área protegida por RPPN em relação ao total de unidades de conservação públicas, entende-se que essas são extremamente importantes para o estabelecimento da conectividade da paisagem natural e a proteção das áreas-chave. Não existe uma legislação específica para a localização das RPPN, mas é comum que a demarcação ocorra próximo às áreas públicas protegidas, funcionando como zonas de amortecimento e corredores ecológicos entre fragmentos florestais e as demais unidades de conservação (Stolton et al., 2014). O mapa 5 destaca a concentração de RPPN próximas ou no interior de unidades de conservação. 
Mapa 5: Distribuição espacial de RPPN em relação às demais unidades de conservação públicas

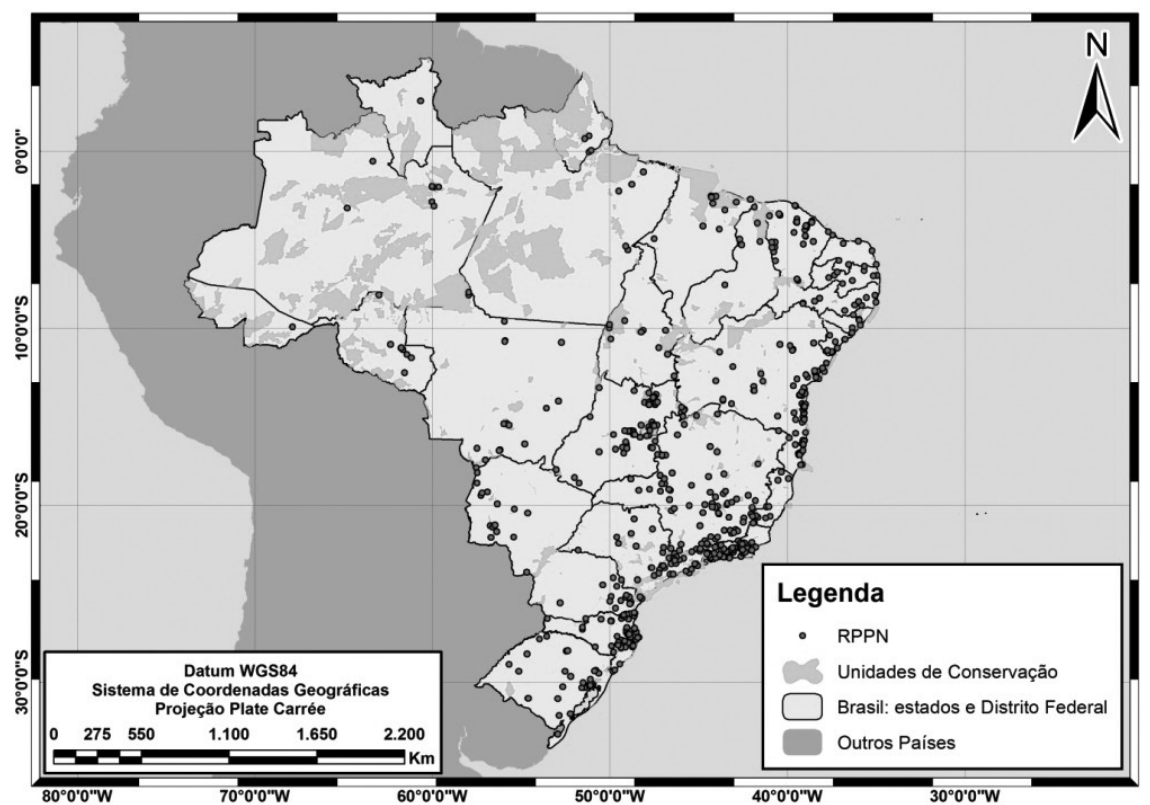

Fonte: Sistema Informatizado de Monitoria de RPPN (SIMRPPN) e Ministério do Meio Ambiente (NEGEF, 2018).

Os mapeamentos apresentados permitem que os padrões de concentração espacial sejam identificados e relacionados com uma dada extensão regional, a qual, por sua vez, apresenta um particular grau de densidade institucional em que se sobrepõem diferentes mecanismos de territorialização e territorialidades afirmativas. Uma vez que as RPPN são iniciativas de que participa uma série de atores, incluindo os proprietários, associações locais, ONGs, pesquisadores, agências governamentais, entre outros, é provável que muitos enfoques de gestão tenham um tipo de governança misto ou compartilhado.

Surgidas em contraposição à ausência de controle e regulação sobre as formas de acesso e uso dos recursos naturais, as políticas ambientais trazem como marca fundamental

a noção de gestão como processo, não automático, de interação entre poderes com o intuito básico de coordenação, orientação e regularização de atores sociais. A gestão tende a assegurar aos grupos sociais nas unidades de conservação 
caráter participativo e estimulador das iniciativas de manejo dos recursos de que são dependentes (Coelho et al., 2009, p. 106).

Apontamos a seguir os principais programas institucionais cujas diretrizes estimulam indiretamente a criação, em nível nacional, de novas unidades de conservação em propriedades rurais: ICMS Ecológico, Cadastro Ambiental Rural (CAR)/Programa de Regularização Ambiental (PRA) e o Programa Produtor de Águas.

O ICMS Ecológico é um mecanismo tributário que garante às prefeituras que investem em conservação ambiental uma fatia maior do Imposto sobre Circulação de Mercadorias e Serviços (ICMS) repassado a elas. Pela legislação tradicional do ICMS, 25\% do arrecadado pelos governos estaduais são distribuídos entre as prefeituras. Com o ICMS Ecológico, as administrações municipais que atingem metas relacionadas à gestão ambiental de unidades de conservação, recursos hídricos e resíduos sólidos recebem uma parcela maior desses recursos.

$\mathrm{Na}$ prática, ao invés de criar um imposto, instituiu-se um novo critério de redistribuição que combina o nível da atividade econômica ao grau de preservação do meio ambiente nos municípios. Para se habilitar a receber recursos do ICMS Ecológico, cada município deverá organizar seu próprio Sistema Municipal de Meio Ambiente, composto, no mínimo, por: (a) Órgão administrativo executor da política municipal de meio ambiente; (b) Conselho Municipal de Meio Ambiente; (c) Fundo Municipal de Meio Ambiente; e (d) Guarda Municipal ambiental.

Segundo May et al. (2005, p. 98),

tal engenharia tributária originou-se como meio de compensar os municípios que possuem unidades de conservação (UC) - seja totalmente protegidas ou restritas a áreas de uso sustentável - dentro de seus territórios pela perda resultante de receita. Como benefício externo positivo, o instrumento também procura estimular tanto a melhoria dessas áreas como a criação de novas UCs.

Estima-se que, para aumentar suas pontuações no Índice Final de Conservação Ambiental (IFC), haja programas específicos para estimular a adesão de proprietários rurais ao modelo RPPN. 
“As instâncias do poder político se organizam nas suas escalas de ação, constituindo uma complexa rede de interações de interesses políticos que se materializa no território" (Castro, 2005, p. 128). Compreende-se que o Código Florestal tem como função primeira estabelecer as leis que protegem as florestas e vegetação nas propriedades privadas rurais no Brasil. O teor normativo é reflexo do campo de forças das representações institucionais, podendo sofrer alterações ao longo do tempo.

Um dos elementos centrais do Novo Código Florestal é a criação do Cadastro Ambiental Rural (o CAR), obrigatório para todos os imóveis rurais no Brasil. O CAR é a primeira etapa para a regularização ambiental dos imóveis rurais. Inscritos no CAR, os proprietários de terras com passivo ambiental áreas de Reserva Legal ou APPs desmatadas que precisam ser recompostas ou compensadas - devem aderir ao PRA (Programa de Regularização Ambiental), que é de responsabilidade dos estados. É, portanto, no nível dos governos estaduais que são definidas as medidas de reflorestamento a serem tomadas pelos donos de terras.

O entendimento institucional é o de que o Código Florestal (Lei $12.651 / 2012$ ) contribui para a adequação ambiental da paisagem rural. O Cadastro Ambiental Rural (CAR), disponível no artigo 29 da Lei 12.651/2012, consiste em um registro público eletrônico, de âmbito nacional, voltado para o levantamento de informações georreferenciadas de todos os imóveis rurais do País, de modo que sejam especificadas as seguintes categorias espaciais autodeclaradas: Área de Proteção Permanente (APP); Área de Reserva Legal (ARL); Área de Uso Restrito (AUR); Área Rural Consolidada (ARC); remanescentes de vegetação nativa; e áreas de interesse social e de utilidade pública (servidões administrativas).

Uma vez permitida a sobreposição de uma futura RPPN em extensões reservadas a Áreas de Preservação Permanente e de Reserva Legal, entendemos que tais medidas restritivas possam estimular potenciais interessados a tomar conhecimento de projetos de manejo e gestão em unidades de conservação privadas promovidos por instituições públicas e do terceiro setor, favorecendo a inserção e a mobilização desses em novas redes institucionais na busca pela captação de recursos e compensações pela inutilização de áreas então reservadas a outras atividades tradicionais.

Outra observação sobre o CAR e o Novo Código Florestal se refere à aquisição de Cotas de Reserva Ambiental por parte daqueles proprietários que 
optaram por compensar o déficit percentual de área destinada à Reserva Legal, uma vez que não tenham alcançado o mínimo exigido por Lei em suas propriedades. Esse grupo, em especial, precisará aderir ao Programa de Regularização Ambiental (PRA). A compensação da Reserva Legal se dá por meio do cadastramento, no âmbito do Sistema Nacional de Cadastro Ambiental Rural (SICAR), em busca de um excedente de Reserva Legal equivalente à área que precisará ser compensada.

Nesse caso, as áreas com superávit florestal poderão estar localizadas em imóveis rurais pertencentes ao próprio detentor do imóvel com passivos ambientais a regularizar, ou localizadas em imóveis de terceiros, sendo necessária a manifestação favorável do segundo proprietário, confirmando a aquisição da área excedente para fins de compensação de Reserva Legal. Nesse contexto, o arrendamento de áreas de vegetação excedente poderá estimular a criação de RPPN como forma de incrementar o valor de troca, ou seja, garantir a qualidade e a integridade do "ativo florestal" a ser negociado.

Em princípio, as RPPN, como extensão de uma política ambiental, visam à ampliação e à manutenção dos chamados serviços ambientais no espaço rural. A abordagem feita pelo programa internacional Avaliação Ecossistêmica do Milênio no ano de 2005 define serviços ambientais como os benefícios que as pessoas obtêm dos ecossistemas. Entre as classificações de serviços ambientais destacadas estão os serviços funcionais prestados pelos ecossistemas, como provisão (produtos obtidos diretamente dos ecossistemas, como, por exemplo, alimentos e água), os de regulação (controle de processos ecossistêmicos, como, por exemplo, controle de pragas e de enchentes), os culturais (benefícios não materiais, como cultural e espiritualidade) e os de suporte (necessários para a manutenção de todos os outros serviços). O grande desafio está na valoração desses serviços com o objetivo de remunerar aqueles proprietários, chamados na literatura de produtores de água e florestas, interessados em contribuir para a preservação ou conservação da biodiversidade.

Desenvolvido pela Agência Nacional de Águas (ANA), o Programa Produtor de Água tem como foco o estímulo à política de Pagamento por Serviços Ambientais (PSA) voltados à proteção hídrica no Brasil. Para tanto, o programa apoia, orienta e certifica projetos que visem à redução da erosão e do assoreamento de mananciais no meio rural, propiciando a melhoria da qualidade, a ampliação e a regularização da oferta de água em bacias hidrográficas de importância estratégica para o País. No estado do Rio de Janeiro, o PPA é representado por 
dois projetos-piloto: Produtores de Água e Floresta - Bacia do Grandu/RJ e Produtor de Água - Bacia do Rio Macaé, ambos ainda em operação.

O referido Programa prevê o apoio técnico e financeiro para o estabelecimento de projetos que viabilizem o pagamento por serviços ambientais e a execução de ações em diversos projetos espalhados por vários estados brasileiros. Entre as ações elegíveis estão a construção de terraços e de bacias de infiltração, a readequação de estradas vicinais, recuperação e proteção de nascentes, o reflorestamento das áreas de proteção permanente e reserva legal, o saneamento ambiental, entre outros.

Enquanto ainda são tímidas as iniciativas de pagamento por serviços ambientais integradas aos componentes normativos que regulam o uso do solo no interior das RPPN, percebe-se uma aproximação dessas com modalidades econômicas não agrícolas, a exemplo do turismo rural (nas modalidades de agroturismo e ecoturismo no entorno da unidade de conservação), e também de atividades ligadas à educação ambiental e pesquisa científica, desde que sejam autorizadas pelo órgão ambiental responsável pelo seu monitoramento. No entanto, tais atividades devem estar presentes no Plano de Manejo - um documento técnico que mapeia e define atividades de acordo com o perfil da área -, como objetivos, estabelecimento de zoneamento, normas de uso dos recursos naturais e o que e onde será construído e realizado na área da RPPN.

Das restrições e densidades normativas que se impõem espacialmente, vislumbram-se emergentes ordenamentos territoriais derivados de novas formas e refuncionalizações da paisagem rural, uma vez que a adesão ao referido modelo pode favorecer o desenvolvimento de variedades agro e ecoturísticas, além de contribuir para a valoração paisagística e simbólica, integrada a circuitos de economia criativa de cunho agroecológico e de educação ambiental no campo.

No que tange à produção-manutenção da paisagem rural, o fenômeno turístico é responsável pela comodificação da paisagem, ou seja, a mercantilização de amenidades espaciais associadas. $\mathrm{O}$ turismo rural, nesse sentido, constitui uma atividade que une a dimensão econômica a outras funções, como a valorização do ambiente rural, da paisagem natural e da cultura local, componentes esses que, não raras vezes, são alguns de seus atrativos principais.

O consumo imagético do campo como um refúgio pictórico, como uma remediação aos excessivos estímulos sensoriais, desencadeadores do blasé urbano, condiciona a seleção de exigências paisagísticas que possam salvaguardar os 
componentes integrantes de simulacros temáticos, formatados e cristalizados em paisagens rurais concebidas sob medida para narrativas fantásticas. O rural se traduz em imagens estereotipadas, divulgadas pelas operadoras de turismo para atrair turistas. Essas mesmas imagens são reinterpretadas como parte de uma estratégia local, tendo em vista resultados econômicos.

A representação social da natureza passa a estar vinculada às noções de valoração estética e de patrimonialização, que se expressam em hierarquias e status diferenciados. Por esse viés, o ecoturismo emerge, em sua versão atual, como uma imersão fantástica, seja como veiculação de um tipo de banalização idealizada de consumo da natureza em sua versão fast food, seja como parte de uma lógica de espetacularização.

As RPPN se inserem, portanto, nesse contexto de conservação e valoração de um quadro paisagístico esperado, o que não necessariamente abrange a totalidade de proprietários rurais que aderiram a esse modelo. De fato, são muitas e variadas as motivações para criar RPPNs. Algumas são para benefício social (por exemplo, conservação ou recreação), outras são para benefício pessoal (por exemplo, privacidade ou benefícios tributários), embora outras estejam relacionadas com assuntos familiares (por exemplo, manter uma propriedade na família ou assegurar fins de conservação para as gerações futuras dentro da propriedade familiar).

O turismo como uma intencionalidade inicial de revalorizar as áreas rurais, ainda que a partir de ressignificações alegóricas, como algo mais do que meras regiões produtoras de alimentos,

inclui seus símbolos identitários (estilos de vida, linguagem, trabalho, arte e artesanato, crenças, relaçóes sociais, formas de lazer, etc.), assim como os entornos físicos humanizados (áreas de cultivo, vilarejos, construções históricas, etc.) e os supostamente não humanizados (bosques, montanhas, vales, etc.), apresentados como paisagens naturais e indômitas (Talavera, 2000, p. 156). 


\section{Considerações finais}

As unidades de conservação, ainda que normalmente relacionadas aos valores e ações dos movimentos ambientalistas,

são projetos territoriais que não podem ser totalmente compreendidos apenas no contexto das políticas públicas voltadas para a proteção da natureza. Produtos sociais, resultantes de complexos processos de cooperação, negociação e conflito entre diferentes atores sociais, as unidades de conservação se inserem em contextos territorializados, devendo, portanto, ser analisadas em termos das dinâmicas mais gerais de territorialização de um determinado espaço ou região (Coelho et al., 2009, p. 104).

Conforme aponta Silva (2014, p. 121), “as gestões públicas multiescalares devem priorizar a ideia de que naturezas e sociedades produzem meio ambientes cujo jogo de forças consonantes e dissonantes pode promover a qualidade de vida e a justiça social". Ainda de acordo com o autor, "é igualmente importante repensar a complexidade da governança nacional para as ações a serem implementadas nas políticas ecológico-ambientais dos territórios” (p. 133). Somente assim, as decisões serão claras, sustentáveis e reconhecidas socialmente, em múltiplas escalas.

A expectativa dessa nova conjuntura sociopolítica é a de que o Estado, como agente territorial hegemônico, seja agora entendido como uma entidade representativa mais "aberta”, dentro da qual a participação da sociedade se transforme em um instrumento básico de decisão sobre os rumos e prioridades da multiplicidade de vetores de desenvolvimento e sustentabilidade. A premissa da democratização dos órgãos públicos, a transparência administrativa, a participação popular nos conselhos, câmaras e nos orçamentos são fatores que inauguram uma dimensão territorial ao desenvolvimento.

O rural como um conceito contestado, ou seja, a noção de ruralidade, é aqui entendido "como a manifestação de variadas territorialidades de grupos sociais, associadas por autoidentificação, e remete a uma pluralidade de movimentos, de origem externa ou interna, que dinamiza o campo, no sentido da atualização dos desafios e potencialidades." (Wanderley e Favareto, 2013). Rural é, portanto, território de ação e ação de atores, palco de reivindicações específicas que demandam políticas apropriadas. Sendo assim, territorialidades competitivas e/ou cooperativas repercutem em variados arranjos socioespaciais 
significativamente ricos à análise geográfica, cujo procedimento deriva de uma dialética entre a descrição e a explicação, e de proposição de questões que começam por: o quê, onde, como e por quê.

Nesse sentido, a delimitação de uma unidade de conservação no interior de uma propriedade rural pode revelar algo mais do que o desejo individual e voluntário de um dado ator social em benefício da preservação ambiental. Esse "ato nobre", analisado por outros ângulos, leva-nos a questionar alguns padróes locacionais de tais iniciativas em determinadas áreas do estado do Rio de Janeiro cuja dependência espacial está associada à convergência de distintas territorializações institucionais. Uma rica trama de intencionalidades e compensações envolve diferentes atores a partir da qual resultam distintos mosaicos de usos do solo relacionados ao mesmo componente espacial - a RPPN.

Conforme aponta Coelho et al. (2009, pp. 106-7), "tomar relações de poder e dinâmicas de territorialização como foco analítico permite a adoção de uma visão menos romântica tanto das populações tradicionais/locais quanto das políticas públicas implicadas na constituição de unidades de conservação no Brasil".

O maior desafio por parte do Estado e da sociedade civil é identificar uma equação ponderada de investimentos para a ampliação de áreas protegidas - sejam estas de uso indireto ou direto, públicas ou privadas - no sentido de encontrar uma fórmula equilibrada composta não apenas de áreas particulares de proteção integral, mas também principalmente integrá-las a outras áreas protegidas de Uso Sustentável. [...] A palavra-chave na relação entre UC públicas e RPPN deve ser "complementaridade", combinando diferentes formas de uso do solo (Costa-Alves e Guimarães, 2009, p. 49).

Esses processos são marcados por relações de poder, por conflitos entre projetos territoriais e pela possibilidade de cooperação entre diferentes atores sociais. Mas, se não reconhecermos essa complexidade e as contradições entre projetos territoriais e dinâmicas de territorialização, a gestão das unidades de conservação se mostrará inviável a médio e longo prazos (Coelho et al., 2009, p. 106).

Em uma sociedade mais saudável, talvez fosse possível disciplinar e gerir o uso dos recursos naturais de forma mais ampla e, quiçá, mais democrática, sem que houvesse necessidade de reservar espaços especialmente para a proteção da natureza. Enquanto houver necessidade de áreas protegidas, é sinal de que a humanidade continua fazendo um uso predatório e insustentável da bio- 
diversidade. Não há dúvidas de que o uso mais racional dos recursos naturais seria a melhor alternativa, mas, enquanto isso não acontece, vale a pena investir nas áreas protegidas e em estratégias mais amplas de proteção e uso racional da biodiversidade (Bensusan, 2006).

\section{Referências}

BENSUSAN, Nurit. Conservação da biodiversidade em áreas protegidas. Rio de Janeiro: Editora FGV, 2006.

BICALHO, Ana Maria de Souza Mello. "Espaço rural contemporâneo: perspectivas teórico-metodológicas”. In ARAÚJO, Ana Paula de e VARGAS, Icléia Albuquerque de (orgs.). Dinâmicas do rural contemporâneo. Campo Grande: Ed. UFMS, 2014.

BRASIL. "Lei n. ${ }^{\circ}$ 4.771, de 15 de setembro de 1965”. Disponível em: http://www. planalto.gov.br/ccivil_03/leis/L4771.htm.

. Constituição da República Federativa do Brasil. Brasília: Senado Federal Centro Gráfico, 1988.

. "Decreto n. ${ }^{\circ}$ 98.914, de 31 de janeiro de 1990". Disponível em: http://www. planalto.gov.br/ccivil_03/decreto/1990-1994/d98914.htm.

. "Decreto n. ${ }^{\circ}$ 1.922, de 05 de junho de 1996". Disponível em: http://www. planalto.gov.br/ccivil_03/decreto/antigos/d1922.htm.

."Lei n. ${ }^{\circ} 9.985$, de 18 de julho de 2000". Disponível em: http://www.planalto. gov.br/ccivil_03/LEIS/L9985.htm\#art21.

. “Decreto n. ${ }^{\circ} 5.746$, de 5 de abril de 2006". Disponível em: http://www.planalto. gov.br/ccivil_03/_ato2004-2006/2006/decreto/d5746.htm.

."Lei n. ${ }^{\circ} 12.651$, de 25 de maio de 2012”. Disponível em: http://www.planalto. gov.br/ccivil_03/_ato2011-2014/2012/lei/112651.htm.

. "Decreto n. ${ }^{\circ} 7.830$, de 17 de outubro de 2012". Disponível em: http://www. planalto.gov.br/ccivil_03/_Ato2011-2014/2012/Decreto/D7830.htm. 
. "Decreto n. 8.235 , de 5 de maio de 2014". Diponível em: http://www.planalto. gov.br/ccivil_03/_Ato2011-2014/2014/Decreto/D8235.htm.

. Instrução Normativa n. ${ }^{\circ}$ 2/MMA, de 06 de maio de 2014. Disponível em: http://www.car.gov.br/leis/IN_CAR.pdf.

CARNEIRO, Maria José. "Do 'rural' como categoria de pensamento e como categoria analítica". In (org.). Ruralidades contemporâneas: modos de viver e pensar o rural na sociedade brasileira. Rio de Janeiro: Mauad X/FAPERJ, 2012.

CASTRO, Iná Elias de. Geografia e política: território, escalas de ação e instituições. Rio de Janeiro: Bertrand Brasil, 2014 [2005].

COELHO, Maria Célia Nunes et al. "Unidades de conservação: populações, recursos e territórios. Abordagens da geografia e da ecologia política”. In GUERRA, Antonio José Teixeira e COELHO, Maria Célia Nunes (orgs.). Unidades de conservação: abordagens e características geográficas. Rio de Janeiro: Bertrand Brasil, 2009.

COSTA, Cláudia Maria Rocha. Potencial para a implantação de politicas de incentivo às RPPNs. Belo Horizonte: Conservação Internacional, Fundação SOS Mata Atlântica, The Natures Conservancy, 2006.

COSTA-ALVES, Andre Luiz da e GUIMARÃES, Guilherme de Azevedo Mendes. "Turismo e agricultura no entorno das RPPN do município de Casimiro de Abreu - RJ sob o enfoque da multifuncionalidade: relação em potencial para o desenvolvimento rural local". CULTUR - Revista de Cultura e Turismo, ano 3, n. 1, jan. 2009.

FLEXOR, Georges e GAVIRIA, Margarita. "A terra, a natureza e as regras: a multifuncionalidade da agricultura em Paraty". In CARNEIRO, Maria José e MALUF, Renato (orgs.). Para além da produção: multifuncionalidade e agricultura familiar. Rio de Janeiro: MAUAD, 2003.

GRAZIANO DA SILVA, José et al. "O que há de realmente novo no rural brasileiro". Cadernos de Ciência \& Tecnologia, v. 19, n. 1, pp. 37-67, jan.-abr. 2002.

MARAFON, Glaucio José. "Permanências e mudanças no campo: transformações no espaço rural fluminense”. In SANTOS, Angela Moulin S. Penalva et al. (orgs.). Rio de Janeiro: um olhar socioespacial. Rio de Janeiro: Gramma, 2010. 
MAY, Peter et al. "O ICMS-Ecológico: respostas ao nível municipal no Paraná e Minas Gerais”. In PAGIOLA, Stefano et al. Mercados para serviços ecossistêmicos: instrumentos econômicospara conservação e desenvolvimento. Rio de Janeiro: Instituto Rede Brasileira Agroflorestal - REBRAF, 2005.

OLIVEIRA, Renata Ribeiro de. "A caprinocultura leiteira em Nova Friburgo e a emergência de novas relações campo-cidade. In BICALHO, Ana Maria de Souza Mello e HOEFLE, Scott William (orgs.). A dimensão regional e os desafios à sustentabilidade rural. Rio de Janeiro: LAGET, UFRJ, 2003.

PECQUEUR, Bernard. "O desenvolvimento territorial: uma nova abordagem dos processos de desenvolvimento para as economias do Sul”. Revista Raizes, v. 24, n. 1 e 2, pp. 10-22, Campina Grande, jan.-dez. 2005.

ROCHA, Alynson S. et al. "Organização social e desenvolvimento territorial: reflexões sobre a experiência dos CMDRS na região de Irecê - Bahia”. In Anais do XLI Congresso Brasileiro de Economia e Sociologia Rural (SOBER), Juiz de Fora (MG), 2003.

SILVA, Augusto César Pinheiro da. "Novas arquiteturas intergovernamentais para a gestão do território fluminense: desafios de um Rio de Janeiro federativo". In SANTOS, Angela Moulin S. Penalva. Rio de Janeiro: um território em mutação. Rio de Janeiro: Gramma/FAPERJ, 2012.

. "Geografia e meio Ambiente: as políticas de Estado na configuração de sustentabilidades no Brasil”. In ACTA Geográfica, Boa Vista, Ed. Esp. Geografia política e Geopolítica, 2014.

SOUZA, José Luciano de e CORTE, Angélica de Araujo. "Reservas Particulares do Patrimônio Natural federais: agregando valor ao Sistema Nacional de Unidades de Conservação". In GUAGLIARDI, Roberta (org.). O panorama atual das RPPN federais e dos estados do Rio de Janeiro, Bahia, Minas Gerais e São Paulo. Salvador, Conservação Internacional-Brasil/Fundação S.O.S. Mata Atlântica/The Nature Conservancy, 2009.

SOUZA, Marcelo Lopes de. "O território: sobre espaço e poder, autonomia e desenvolvimento”. In CASTRO, Iná Elias de et al. Geografia: conceitos e temas. Rio de Janeiro: Bertrand, 1995. 
STOLTON, Sue et al. Áreas Bajo Protección Privada: Mirando al Futuro. Gland: UICN, 2014.

TALAVERA, Augustin Santana. "O rural como produto turístico: algo de novo brilha sob o sol?”. In SERRANO, Célia et al. Olhares contemporâneos sobre o turismo. Campinas: Papirus, 2000.

VINHA, Valéria e MAY, Peter. H. "A biodiversidade e a governança verde no Brasil: soluções inovadoras na gestão dos recursos para a conservação e equidade”. Desenvolvimento em Debate, v. 3, n. 1, pp. 89-109, 2014.

WANDERLEY, Maria Nazareth Baudel e FAVARETO, Arilson. "A singularidade do rural brasileiro: implicações para tipologias territoriais e a elaboração de políticas públicas". In MIRANDA, Carlos. e SILVA, Heithel (orgs.). Concepções da ruralidade contemporânea: as singularidades brasileiras. Brasília: IICA, 2013. 


\title{
4. Turismo rural: resgatando conceitos e atualizando reflexões
}

\author{
Glaucio José Marafon \\ Valéria Maria de Souza Lima
}

\section{Introdução}

Tradicionalmente, o campo brasileiro tem exercido a função tanto de fornecedor quanto de consumidor da cidade, seja provendo necessidades com matéria-prima ou recursos humanos para o trabalho, seja absorvendo mercadorias e facilidades. A análise de tais transformações ganha, ainda, maior importância quando consideramos que as atividades desenvolvidas no campo passam a se configurar, cada vez menos, como agrícolas, abarcando sobremaneira a produção industrial e os serviços associados ao turismo, em vista da crescente valorização das áreas ricas em aspectos naturais.

Além disso, há que se destacar o contínuo processo de migração da cidade para o campo, na busca das pessoas por sua inserção no mercado de trabalho e pelo apelo de uma melhor qualidade de vida. Local da produção agropecuária, o campo transforma-se, assim, em um espaço onde se observa a realização de inúmeras atividades não agrícolas, como o trabalho de caseiros, diaristas, jardineiros etc.

Nesse contexto, o espaço rural torna-se fortemente marcado pelo conteúdo de técnica e capital, sendo representado pelos complexos agroindustriais e pelo agronegócio, correspondentes ao espaço de produção agrícola, fruto da revolução verde, da modernização e da industrialização da agricultura. O espaço rural da produção familiar passa a ser também evidenciado pelas atividades não agrícolas, que valorizam os patrimônios naturais e históricos nele presentes.

É importante lembrar que tais mudanças no campo acarretam transformações na própria organização do espaço como um todo, envolvendo interes- 
ses de fora do meio rural. Assim, este permanece na forma dos casarões, das roças, de alguns objetos que identificam o campo como rural, porém a sua função não é mais exclusivamente agrícola, como frisado por Woods (2007, p. 491):

\begin{abstract}
A rural realm constituted by multiple, shifting, tangled and dynamics networks, connecting rural to rural and rural to urban, but with greater intensities of globalization processes and of global interconnections in some rural localities than in others, and thus with a differential distribution of power, opportunity and wealth across rural space.
\end{abstract}

Em face de toda essa diversidade, percebe-se hoje a maior preocupação com a preservação natural, em vista da intensificação de atividades econômicas e interesses sociais que propiciam o surgimento de novas funções para o produtor rural e dinamizam o seu espaço de atuação, com aproveitamento de novas fontes de energia e de amenidades propiciadas pelos centros urbanos próximos.

Nesse caso, temos um campo diferenciado, preparado para ser consumido pelos moradores da cidade e onde a indústria e a lógica capitalista já se fazem presentes. Sem dúvida, esse espaço rural está cada vez mais se adequando aos hábitos urbanos para atender às exigências dos moradores citadinos e, nessa configuração, o entendimento dessas áreas ultrapassa a ideia de encará-las como espaços antagônicos. Temos, dessa forma, urbanidades no espaço rural, assim como proposto por João Rua (2006).

Em busca de reprodução e sobrevivência, a produção familiar tem apresentado características como o trabalho em tempo parcial em face da diminuição da jornada de trabalho (favorecida pela incorporação de tecnologias de produção), ou seja, há liberação de membros da família para exercerem outras atividades, agrícolas e não agrícolas, complementando assim a renda familiar.

Entre as atividades não agrícolas presentes no campo, merecem destaque na atualidade as atividades turísticas, diante da proliferação das áreas destinadas ao lazer. Essas "novas" atividades têm demandado um número crescente de pessoas para dar sustentação à expansão do turismo no espaço rural, possibilitando que os membros das famílias, liberados das atividades rotineiras da exploração agrícola, passem a ocupar as vagas de trabalho geradas por essa necessidade. 
Diante desse contexto, as atividades turísticas no campo desempenham o papel de mais uma fonte de renda para muitas famílias, contribuindo para a manutenção e a reprodução das atividades agrárias. Contudo, enfatiza-se a preservação e a proteção da natureza, valoriza-se a busca da autenticidade dos elementos paisagísticos locais, a conservação e a proteção dos patrimônios históricos e culturais e o resgate da memória e da identidade. Desse modo, há a mercantilização das paisagens, com a consequente expansão das atividades de turismo e de lazer.

Essa realidade já se faz presente nos campos de todos os estados brasileiros, como é o caso do que se observa na relação campo-cidade nos estados da Paraíba e do Rio de Janeiro, em análise no presente texto, identificando o turismo rural como importante elemento de transformações nas áreas rurais.

Assim, uma vez que nossas investigações caminham pelo viés do espaço rural, podemos pensá-lo como híbrido no Brasil, de múltiplas funções, com a presença dos complexos agroindustriais, da produção familiar, das atividades não agrícolas, de agricultores e não agricultores, que interagem e criam conexôes espaciais. Esses sujeitos participam de redes complexas e imprimem uma marca própria ao espaço rural.

Destarte, neste capítulo, propomos refletir sobre as atividades turísticas em espaços rurais, resgatando noções sobre como tais atividades se organizam em segmentos para fins de estratégia de planejamento, recurso importante de ser observado na busca de melhor compreensão do comportamento bastante dinâmico desse complexo fenômeno.

A cada dia surgem mais e novos temas do turismo, respondendo ao apelo de impulsos específicos que levam aos deslocamentos e às viagens. Pensar a segmentação do turismo para além das noções de mercado e de concorrência é um desafio que nos leva ao esforço de capturar do fenômeno turístico a sua essência, ou seja, o potencial transformador inerente à experiência que pode ou não se realizar. Nessa perspectiva, a força transformadora do turismo parece estar mais presente em alguns temas, como é o caso do turismo rural.

As múltiplas concepções sobre o turismo praticado no espaço rural têm tantas vertentes quanto são os recortes possíveis de serem feitos em relação ao que pode ser considerado rural, enriquecendo a diversidade de conceitos e a gama de vivências turísticas. É no contexto das relações globais e frenéticas da atualidade que buscamos atualizar as reflexóes sobre o turismo rural, no enredo do território e do espaço. 


\section{Espaço rural e turismo rural como segmento}

Num primeiro momento, é importante explicitar o que entendemos por espaço rural a fim de balizarmos as discussões sobre as transformações em curso no campo brasileiro, fortemente marcado pelo agronegócio de bases modernas e biotecnológicas e pela produção familiar. De fato, o campo apresenta enorme gama de variações no território brasileiro, seja pelos níveis tecnológicos diferenciados, pelas estratégias de sobrevivência e de enfrentamento do êxodo, seja pela força dos movimentos sociais na luta pelo acesso à terra.

Em face do exposto, perguntamo-nos: que imagens surgem à nossa mente quando pensamos em espaço rural, espaço de produção agrícola e pecuária, florestas, campos, espaço de turismo, de segunda residência, áreas menos modernas ou mais modernas? Quais são os principais problemas associados ao espaço rural?

Michel Woods (2005) sinaliza a existência de quatro amplas abordagens utilizadas para caracterizar o espaço rural. A primeira delas remete à descrição, para a distinção geográfica entre áreas urbanas e rurais, baseando-se nas características socioespaciais expressas por meio de dados estatísticos; a segunda está atrelada aos aspectos socioculturais e procura identificar os territórios rurais por meio de tais características, com a distinção entre os aspectos das sociedades urbanas e rurais; a terceira considera o rural como lugar, ou seja, em como as estruturas locais interagem com os processos econômicos e sociais globais; e, por fim, o rural é tomado como representação social, que privilegia, na abordagem, os símbolos, ou seja, os sinais e imagens pessoais que surgem quando os indivíduos pensam sobre o rural. A ruralidade aparece como um estado de espírito, como uma identificação com esse espaço. O rural não está apenas associado às estatísticas, ele é caracterizado pelas pessoas que nele vivem e pelo modo como elas se sentem habitando esse espaço.

Dessa forma, o rural emerge como um espaço híbrido que apresenta um complexo jogo de inter-relações com agentes naturais e sociais e uma grande diversidade e dinamismo. No campo, são inúmeras as interações espaciais e redes geográficas formadas pelas empresas que integram os complexos agroindustriais compostos por atores heterogêneos, como empresas, produtores rurais e turistas. Esses atores encontram-se associados a uma variada gama de caminhos, sobretudo com a valorização dos patrimônios natural, histórico ou cultural. 
Se admitirmos a possibilidade, no período atual, do hibridismo para a caracterização do espaço rural, devemos buscar elencar algumas de suas características. De acordo com Kayser (1996), Diry (2004), Woods (2005) e Ferrão (2000), o espaço rural apresenta baixa densidade populacional, predomínio da atividade agro-silvo-pastoril (produção agropecuária e florestal), modo de vida de seus habitantes caracterizado pelo pertencimento às coletividades, e uma identidade fortemente marcada pela cultura camponesa. Porém, essas não são as únicas características presentes nesse espaço, uma vez que temos as atividades não agrícolas e outras ligadas à indústria, ao comércio e a serviços, próximas às aglomerações urbanas.

Devemos também ponderar sobre o papel do meio natural, o papel da técnica, da herança histórica e da tradição, e sobre o papel das grandes corporaçôes que articulam o local e o global. Portanto, é necessário analisar quais são suas funções e como agem as grandes empresas em nível global e como suas estratégias globais são estabelecidas localmente.

Concordamos com Jean (2007) quando este afirma que o espaço rural não se reduz unicamente à atividade agrícola. A agricultura não corresponde ao seu foco estruturante, pois este apresenta novas relações, como, por exemplo, o crescimento do contingente populacional em busca de vantagens comparativas, seja por meio de empregos não agrícolas (vinculados ao setor industrial ou de serviços), seja na busca de espaços residenciais. Assim, o espaço rural, de uma função predominantemente agrícola, passa a apresentar outras funções. Para Jean (2007), assistimos também, no espaço rural brasileiro, ao renascimento do rural e de suas várias funções.

Portanto, ao falarmos de rural e de transformações em curso, estaremos necessariamente nos referindo ao processo de urbanização (das ocupações não agrícolas, da expansão do consumo e da acessibilidade). Em grande medida, identificamos, assim, os espaços de lazer, de produção industrial e de "processos de produção de valores simbólicos”, como informa Reis (2001, p. 7). Ao estudar Portugal, esse autor aponta como principais transformaçôes a maior urbanização, o cosmopolitismo dos comportamentos e a intensa relação com os mercados de trabalho. Concordamos quando ele afirma que

parece claro que as mudanças no meio rural e a maior territorialização das práticas socioeconômicas comportam uma mais intensa relação quer com políticas públicas, quer com agentes externos (que seguem essas políticas). Esta 
dupla abertura do espaço rural (a que lhe é trazida por agentes externos que o procuram segundo novos interesses e novas lucratividades e a que resulta da própria metamorfose dos agentes originariamente locais) é com certeza o grande traço de novidade para o que aí vem. Resta, pois, continuar a observar de que modo abertura e mudança geram novas mudanças.

Dessa forma, os estudos e pesquisas sobre a segmentação em turismo, inclusive no espaço rural, têm levado em conta aspectos relacionados à oferta dos destinos e às motivações, ou seja, à demanda turística, servindo tanto para observar interferências socioculturais quanto a dinâmica desse setor.

No que se refere à tipologia da demanda turística, vemos o esforço de Erik Cohen (Burns, 2002) para construir categorias conforme as conexões mantidas pelos turistas com o território, em especial, no que se refere às relações socioculturais que eles experimentam nos destinos que visitam. Desse modo, os turistas são considerados institucionalizados ou não, de acordo com o grau de intermediação de suas viagens por operadoras e agências de turismo. Essencialmente, tais estudos tomam por orientação os níveis de suficiência presentes ou não nas trocas culturais entre turistas e residentes, ou ainda certo envolvimento e interesse do turista por elementos culturais do destino por ele visitado.

Barretto (2000) infere que as maiores interferências provocadas no território seriam produzidas pelo padrão de turistas institucionalizados ou de massa, preocupados, prioritariamente, em ter uma experiência prazerosa. Estes seriam os que "preferem praias ou hotéis de lazer, parques temáticos e áreas onde possam divertir-se em contato com a natureza, com atividades físicas", cuja tendência é ter menos contato com a população local. Contudo,

o paradoxo desse tipo de turista [institucionalizado] é que provoca grandes alterações na dinâmica da sociedade receptora, que se reflete em mudanças nos usos e costumes, na divisão social do trabalho, no relacionamento interpessoal, sobretudo no familiar, sem que haja contatos realmente interativos com a população receptora. Esta última só tem visibilidade como prestadora de serviços, e, por sua vez, o turista é visto pela população local apenas como um fator de produção, um capital ambulante, um portador de dinheiro com o qual tudo se comercializa, até o sorriso (p. 24). 
No que se refere ao turista não institucionalizado, a autora esclarece que, em número ainda pequeno, "são pessoas que procuram um contato autêntico e íntimo com a população local, fazendo questão de respeitar o modo de vida desta última, [...] adaptando-se facilmente à cultura local e são consumidores de um estado de espírito e não de coisas materiais" (p. 24).

É, fundamentalmente, para esse último tipo de turista, o não institucionalizado, que surgem cada vez mais subsegmentos, ou propostas alternativas em turismo, do ponto de vista da oferta ou da diversidade de temas que pode motivar o deslocamento de pessoas para fora do seu entorno habitual. Barretto (2000) mostra que, de fato, existem ao menos cem diferentes espécies de turismo, de acordo com critérios específicos (p. 19). Mas, de modo geral, pode-se dizer que a busca pela experiência turística é fortemente motivada por atrativos naturais ou culturais, relacionados esses últimos a aspectos da história ou do cotidiano das comunidades visitadas.

Segundo a Organização Mundial do Turismo (OMT) (2001), a ampliação do turismo temático, ou seja, aquele que se organiza a partir de determinados objetos para atrair e atender a nichos específicos de demanda turística, tem sido influenciada pelo surgimento de motivações cada vez mais especiais ou exclusivas por parte dos turistas, não só por conta de necessidades de ordem subjetiva, mas também em face de novos modelos de consumo da experiência turística. Desse modo, o turismo temático tem sido menos apropriado como alternativa socioeconômica para regiões menos favorecidas, do que como estratégia para diferenciação de produtos turísticos em relação a ofertas altamente competitivas.

Conforme a OMT (2001), o mote do turismo temático poderá centrar-se em torno de um "personagem, jogo, tecnologia, costume, espaço, conceito global, ficção”, destacando como principais temas agregados ao turismo a cultura, a aventura, os negócios, o esporte, a saúde, a natureza e o espaço rural (p. 130). Esses grandes eixos podem, ainda, apresentar ramificações, assumindo a segmentação turística grande importância em face de novas exigências de demanda:

Atualmente a satisfação do consumidor é conseguida apenas com a segmentação efetiva e uma grande variedade de ofertas e, para tanto, os atrativos deveriam ser projetados para segmentos específicos. As velhas soluçóes padronizadas não são mais viáveis nem para os turistas, nem para os moradores da área onde se (OMT, 2001, p. 132). 
Pires (2002), porém, vê a motivação como tema ainda carente de maiores estudos e, no caso do turismo, sem respostas que ajudem a compreender os impulsos das viagens, de tal sorte mesclados, que muitas vezes mascarariam a principal razão do deslocamento. Para o autor, essa é uma das maiores problemáticas presentes em alguns segmentos, como o turismo rural, por exemplo, respondendo também pela dificuldade de que pesquisas possam melhor aferir a balança comercial do setor.

Verbole (2002) esclarece que, de fato, “o Turismo Rural está sustentado pela 'percepção do imaginário' [...] e a imagem associada ao segmento está permanentemente sendo desconstruída e reconstruída, uma vez que está sujeita a diferentes e complexos significados e interpretações" (p. 131). Por serem impulsionados por motivos, expectativas e percepções diversas, os turistas rurais estariam longe de serem considerados, nessa perspectiva, um grupo homogêneo.

Para Talavera (2000), podem-se identificar ao menos dois grupos tipológicos de turistas rurais: um com interesse na paisagem rural e na prática de atividades desportivo-recreativas; outro que se deixa encantar, em certa medida, pelas culturas dos locais que visita.

Também as diversas teorias sobre motivação não nos parecem suficientes para identificar um só motivo que se destaque como principal propulsor do turismo rural, ou um único e determinado tema ou enredo que caracterize esse segmento.

Se as motivações humanas compõem uma teia de intrincados interesses e necessidades, não podem ser consideradas de modo descolado das situações em que são enredadas. Nesse sentido, talvez seja mais adequado pensar os segmentos turísticos dentro do contexto do espaço onde se dá a experiência turística, tendo por cenário a dinâmica característica do turismo como fenômeno.

\section{O embaraço dos conceitos}

O turismo rural está definido pela OMT (2001) como o segmento que se refere "a atividades que são feitas no campo, seguindo os costumes e as tradições vividas em ambientes distantes das cidades e áreas industrializadas, como povoados, sítios, etc." (p. 129).

Tulik (2003) nos remete a uma discussão presente em vários estudos sobre o turismo rural, informando que essa expressão vem sendo empregada de modo extensivo a qualquer atividade turística no espaço rural e que se identifica 
no uso corrente com os termos “Turismo no Espaço Rural e Turismo nas Áreas Rurais" (p. 9).

Como categoria que nos importa observar, embora alertados por Santos (1978) de que espaço e território podem ser dotados de diferentes significados historicamente distintos, flexíveis e mutáveis, adotamos do autor a apreensão de que o espaço é um "campo de forças" de formação desigual, revestido de certa autonomia, como "resultado de uma práxis coletiva que reproduz as relações sociais" (p. 171).

Abarcado como totalidade advinda dos processos e das relações sociais do passado e do presente, o espaço geográfico é, nesse sentido, organizado, produzido e reproduzido pelo homem e, em última instância, pela sociedade. Desse modo, podem mudar as formas e funções que ajudam a organizar e a conceber o espaço, ou melhor, à medida que muda a sociedade, muda também o espaço que dela resulta.

Essa vertente nos leva a pensar que, para se observar o turismo no espaço rural, caberá pensar o espaço organizado pela sociedade a partir de formas e funções que se vão definindo historicamente, no passado e no presente, de modo processual e dinâmico.

Como segmento, embora haja uma tendência última para que o turismo rural passe a representar apenas aquelas atividades ligadas de modo mais estreito e efetivo ao conteúdo rural, a questão, segundo Tulik (2003), torna-se sempre mais complexa, principalmente em face das grandes dificuldades encontradas ainda hoje na distinção entre espaço urbano e espaço rural.

Como mostra a referida autora, uma das questões controversas diz respeito ao uso aleatório de vocábulos aplicados ao turismo rural como se fossem sinônimos, mas cujos conceitos são específicos, tais como área, espaço, zona e meio.

Um debate mais enleado se trava em relação aos critérios que servem para delimitar o que seja urbano ou rural pela oposição e confronto entre estes (atividades, funções e características de cada uma dessas dimensões), pela verificação do tamanho e características demográficas de zonas rurais ou urbanas ou pela delimitação político-administrativa entre perímetro urbano e rural. Embora haja uma crescente preocupação de muitos estudiosos do tema em procurar indicar com clareza tais limites, esta não se mostra uma tarefa fácil, mas de linhas muito tênues. 
O esforço para vencer a oposição entre urbano e rural remete aos recortes que consideram ora a aglomeração de casas e pessoas contraposta à habitação dispersa e difusa, ora a observação da dimensão e características das populações residentes em uma área urbana ou em uma área rural. Até mesmo as atividades desenvolvidas nesses espaços chamados de urbano ou rural são utilizadas à guisa de oposição, viés que ainda traz de modo superficial a polêmica contraposição entre o que é rural e o que é agrícola.

No campo do turismo segmentado, o nexo que se tenta estabelecer pela delimitação do perímetro urbano/rural se faz ainda mais perdido em virtude da eventual ampliação dos territórios chamados urbanos, conforme pode autorizar ou não a autonomia do governo municipal, tendo como pano de fundo a arrecadação de impostos. É assim que Rodrigues (2003) argumenta que o sem número de desmembramentos municipais ocorridos nos últimos anos no Brasil provocaram, com autorização legal, a criação artificial de pequenos centros urbanos com características eminentemente rurais.

É o caso de loteamentos em áreas rurais, cujas superfícies das unidades de desmembramento (lotes) estando abaixo do módulo rural são decretadas como áreas urbanas, recebendo tratamento como tal, por meio de implantação de infraestrutura urbana, o que vem justificar o pagamento de tributos urbanos (p. 107).

Locatel (2013) reitera a arbitrariedade presente na definição do que é o espaço urbano, ou da cidade, assim definido tão somente pela área que se considera administrativa, sendo o campo considerado apenas pelas relações sociais e de produção. Conforme o autor, ambos, cidade e campo, seriam dois subespaços orgânicos de uma mesma totalidade e lógica social. Há que se discutir, ainda, a ideia de continuidade entre os territórios urbano e rural, e, consequentemente, a possibilidade de que o mundo contemporâneo esteja fadado a conviver com o hibridismo que faz surgir diferentes graus de ruralidade.

Para Moreira (2002), a dimensão do território ganha destaque nesse debate, na medida em que o espaço rural incorpora elementos simbólicos e materiais que seriam urbanos. Essa relativa maleabilidade conceitual favoreceria, de tal modo, a agregação de atributos econômicos aos conceitos, que podem servir a indicadores que justifiquem iniciativas enredadas pelo poder hegemônico. 
Na perspectiva de Raffestin (1993), território é o espaço onde o trabalho se realiza, gerando energia ou informação, ou seja, eivado de manifestações de poder, de tal modo que, ao se apropriar de um espaço, o ator estará territorializando o mesmo. Já Santos (1996) entende o território a partir de seus usos, da associação de identidade criada pelo sentimento de pertencer a este ou de exercitar a vida social, cultural, afetiva, material e espiritual. De todo modo, esses são olhares que ajudam a aprofundar a reflexão sobre os limites improváveis entre o urbano e o rural.

No caminho de superar essa dicotomia rural-urbano, Teixeira e Lages (1997) chamam a atenção para o fato de que o termo rural não estaria restrito tão somente a questões de localização, como na oposição campo-cidade, mas revestir-se-ia de caráter particular relacionado à terra e aos modos de se relacionar com aquele espaço. O rural não estaria, portanto, subordinado ao urbano, gozando de certo status e expandindo-se para além das atividades agrícolas ou para a pluriatividade, marcando, assim, uma "nova” ruralidade.

Rua (2005) lembra que a proposta de existência das "novas ruralidades" aceita a possibilidade de que o rural e o urbano convivam no mesmo espaço. Reforça, assim, que a presença de urbanidades no meio rural não seria por si só suficiente para transformar o cotidiano rural em cotidiano urbano. Tampouco essas áreas híbridas dão a se distinguir por vezes como urbanas ou rurais, ainda que quase sempre sejam marcadas por uma grande assimetria, em que o urbano se destaca como dominante.

Rodrigues (2003) alerta, inclusive, sobre as artificialidades que serviriam para confundir ainda mais o mundo rural e o mundo urbano, considerando a presença ou não de certas modernidades nesses espaços, já que ambos estariam irremediavelmente marcados, na atualidade, pelos avanços da ciência, da técnica e da informação, em maior ou menor escala.

Uma das fortes marcas dessa nova ruralidade, para Silva (2011), é a pluriatividade, que combina atividades agrícolas e não agrícolas, uma vez que o espaço rural pode servir de palco para práticas diversas e não necessariamente ligadas à produção de alimentos, tal como mostram os diversos segmentos do turismo em contato com a natureza e a vida no campo.

Marafon e Ribeiro (2006) apontam o turismo rural como alternativa para os agricultores familiares que buscam complementar a renda empregando a sua força de trabalho em pluriatividades, ou seja, em empregos temporários em hotéis-fazenda, spas rurais e casas de segunda residência. Nesse caso, a 
pluriatividade não se apresentaria como fenômeno conjuntural, mas como consequência da transformação da agricultura e da reestruturação econômica forjada pelo modelo capitalista.

Para Cunha (apud Tulik, 2003, p. 23), a referência ao rural não pode prescindir de levar em conta as características sociais, culturais e ambientais inerentes a esse termo:

Neste contexto, a zona rural será aquela cujas atividades econômicas tenham uma base agrária e florestal, com atividades agrícolas e florestais, além da pecuária e produtos derivados; deve caracterizar-se pela existência da vida natural e selvagem, em que a produção industrial seja esporádica e a cultura e as tradiçôes se identifiquem, fortemente, com o ambiente e com as forças da natureza.

Rodrigues (2003) reforça essa premissa ao afirmar que “o Turismo Rural estaria correlacionado a atividades agrárias, passadas e presentes, que conferem à paisagem sua fisionomia nitidamente rural" (Rodrigues, 2003, p. 103).

Nesse ponto, entra em pauta, ainda, o hibridismo paisagístico insistente de algumas localidades que embaça o olhar sobre o que é rural ou ecológico, levando alguns autores à adoção do termo turismo "ecorrural" em seus encaminhamentos.

Em referência à paisagem, Pires (2003) lembra que o turismo é motivado, fundamentalmente, pela quebra da rotina e que esta é assegurada pela mudança física de lugar - constatação que se dá pela alteração da paisagem.

Ao apresentarem estudos sobre as abordagens geográficas da paisagem, Britto e Ferreira (2011) sinalizam a ausência de avanços conceituais que extrapolem os elementos "da visão, do belo, do afetivo, do físico ou do cultural”, ou mesmo que integrem campo e cidade, do ponto de vista de suas paisagens, como constitutivas de um "espaço geográfico globalizado" (p. 9).

No esforço de esclarecer o que viria a ser a paisagem rural, Pires (2003) lança mão dos vieses da topografia e do uso do solo, e inclui em sua análise o conceito de paisagem "humanizada" como "produto social, o resultado de uma transformação coletiva da natureza; a projeção cultural da sociedade num determinado espaço" (p. 127). A combinação de variados elementos remeteria, então, a duas subtipologias básicas da paisagem rural: a paisagem campestre e a 
paisagem cultivada, lembrando que outros componentes poderão ser agregados como típicos do meio rural na configuração cênica da sua paisagem, tais como:

[...] povoados e vilarejos isolados, estradas e caminhos de terra, cercas e divisores (de vegetação, pedra ou aramado), pontes e passagens rústicas, açudes, rodas d'água (de moinhos, alambiques), estábulos, mangueiras, galpões, templos religiosos, cemitérios, estalagens e armazéns de beira de estrada, escolas isoladas, fornos de carvão, estufas, etc. (Pires, 2003, p. 126).

Consoante a edição em 2004 das Diretrizes para o Desenvolvimento do Turismo Rural (Ministério do Turismo), o rápido e ainda desordenado crescimento dessa atividade no Brasil vem gerando uma "profusão de entendimentos" que se têm confundido com múltiplas concepções e denominaçôes, tais como: agroturismo, ecoturismo, turismo de interior, turismo no espaço rural, alternativo, endógeno, verde, campestre, agroecoturismo e ecoagroturismo.

Teixeira e Lages (1997) ratificam que o espaço agrário ou agrícola seria uma das atividades ou especificidades do rural.

Buscando lançar luz à questão, o Ministério do Turismo (2004) apresenta nas Diretrizes a definição do Turismo no Espaço Rural "como um recorte geográfico, onde o Turismo Rural está inserido”, adotando para aquela expressão o conceito que compreende:

todas as atividades praticadas no meio não urbano, que consistem de atividades de lazer no meio rural em várias modalidades definidas com base na oferta: turismo rural, agroturismo, turismo ecológico ou ecoturismo, turismo de aventura, turismo de negócios, turismo de saúde, turismo cultural, turismo esportivo, atividades estas que se complementam ou não (Graziano da Silva et al. apud Ministério do Turismo, 2004, p. 11).

Nessa lógica, estariam incluídos como atividades no meio rural os serviços de hospedagem e alimentação, a visita a propriedades rurais, as atividades de entretenimento ou pedagógicas desenroladas no contexto rural, assim como quaisquer outras atividades turísticas praticadas no meio rural que se constituam em motivo de visitação (Ministério do Turismo, 2004, p. 12). 
Campanhola e Graziano da Silva (1999) detalharam ainda mais, em outra oportunidade, o que compreendem como "turismo no meio rural":

atividades de lazer no meio rural em várias modalidades definidas com base na oferta: turismo rural; turismo ecológico ou ecoturismo; turismo de aventura; turismo de negócios; turismo cultural; turismo jovem; turismo social; turismo de saúde; e turismo esportivo. Nesse conceito incluem-se, por exemplo, os 'spas' rurais; os centros de convenções rurais; os locais de treinamento de executivos; os parques naturais para atividades esportivas; as caminhadas; as visitas a parentes e amigos; as visitas a museus, igrejas, monumentos e construções históricas; os festivais, rodeios e 'shows' regionais, as visitas a paisagens cênicas e a ambientes naturais; a gastronomia regional; os 'campings', as colônias de férias, os hotéis-fazenda, ${ }^{8}$ as fazendas-hotéis, ${ }^{9}$ os esportes da natureza, como canoagem, alpinismo, pesca, caça; chácaras de recreio e condomínios rurais de segunda moradia, entre outros (pp. 14-5).

Quanto ao turismo rural, este é o conceito apresentado pelo Ministério do Turismo (2004) e que, de modo geral, sustenta a posição da Embratur em 1998, cujo cunho mercadológico é apontado por Silveira (2003) como o “conjunto de atividades turísticas desenvolvidas no meio rural, comprometido com a produção agropecuária, agregando valor a produtos e serviços, resgatando e promovendo o patrimônio cultural e natural da comunidade" (Ministério do Turismo, 2004, p. 11).

Finalmente, cabe dar destaque ao termo agroturismo, que, no nosso entendimento, torna as teias da categorização do turismo no espaço rural ainda mais intrincadas, como vemos:

[O agroturismo] compreende as atividades internas à propriedade, que geram ocupaçôes complementares às atividades agrícolas, as quais continuam a fazer parte do cotidiano da propriedade, em menor ou maior intensidade. Devem

8 "Hotéis nos moldes tradicionais, apenas instalados no meio rural, com atividades de lazer restritas a seu entorno" (Campanhola e Graziano da Silva, 1999, p. 14).

9 "Hotéis instalados em propriedades agrícolas produtivas; constitui-se atividade do agroturismo" (Campanhola e Graziano da Silva, 1999, p. 14). 
ser entendidas como parte de um processo de agregação de serviços e bens não materiais existentes nas propriedades rurais (paisagem, ar puro, etc.) a partir do 'tempo livre' das famílias agrícolas, com eventuais contratações de mão de obra externa (Graziano da Silva et al. apud Ministério do Turismo, 2004).

Graziano da Silva (apud Campanhola e Graziano da Silva, 2003, p. 14) cita como exemplos de agroturismo "a fazenda-hotel, o pesque-pague, a fazenda de caça, a pousada, o restaurante típico, as vendas diretas do produtor; o artesanato, a industrialização caseira e outras atividades de lazer associadas à recuperação de um estilo de vida dos moradores do campo".

Para alguns autores, o agroturismo seria uma subdivisão do turismo rural e teria como princípios norteadores a interligação com atividades inerentes à propriedade (agrícolas ou pecuárias), o objetivo de complementação de renda familiar por via da atividade turística, a gestão familiar (com presença obrigatória do proprietário), o alojamento de turistas na propriedade, a venda de produtos locais, a experimentação de atividades da propriedade e o contato estreito do turista com o meio rural (Tulik, 2003, pp. 38-9).

Tulik (2003), entretanto, admite que "na prática, outros tipos de turismo rural assimilaram as características do agroturismo, e que esse tipo de turismo, considerado por alguns como o mais fácil de ser compreendido, desviou-se de alguns desses objetivos" (p. 39).

Rodrigues (2003) traz uma reflexão interessante sobre o "lazer periurbano" e o "turismo periurbano", lançando a questão sobre "a relação do proprietário ou do empreendimento com o entorno onde a atividade se realiza" (p. 106). A autora espera que a resposta defina o real vínculo histórico ou afetivo presente na atividade, ou se esta seria apenas de cunho comercial.

No caso da compra de um terreno e a posterior construção de um lago para pesque-pague, restaurante, lanchonete, sem nenhum vínculo paisagístico ou afetivo com o lugar, em que o proprietário nem reside no local e quase tudo está a cargo de empregados, ao nosso ver trata-se de um empreendimento que, apesar de se localizar fora do perímetro considerado urbano pouco se caracteriza pela ruralidade. Nem mesmo as relaçôes de trabalho são específicas do mundo rural. O proprietário pode residir na cidade. Os funcionários são 
também urbanos e/ou terceirizados, podendo ser recrutados por uma empresa, recebendo sob o regime de comissão pelo valor arrecadado (p. 106).

Prosseguindo nessa discussão, Rodrigues (2003) lembra os casos em que espaços antes essencialmente rurais foram modificados com o tempo e que provocaram, consequentemente, a transformação ou o abandono de certas instalações que perderam a utilidade e cita o exemplo de antigos haras que, adaptados, passaram a ser alugados para festas de casamento. Mais complicados para aquela autora seriam os casos de propriedades localizadas em zonas periurbanas e que nunca tiveram cunho rural, também bastante usadas para servir a festas de caráter urbano. A rigor, tais atividades sequer poderiam ser caracterizadas como turísticas e se constituiriam no que chama de "lazer periurbano" (p. 106).

Por outro lado, Rodrigues (2003) lembra a existência de espaços urbanos que tentam reconstruir o meio rural para fins pedagógicos, ou mesmo com o objetivo de proporcionar entretenimento e recreação, a exemplo da "fazendinha” do complexo Beto Carrero, no bairro do Brooklin, em São Paulo.

Nessa reedificação do rural, encontram-se também os eventos organizados em espaços nitidamente urbanos, como mostra a referida autora:

Está havendo um tipo de lazer e/ou de turismo rural às avessas, ou seja, a cultura rural colonizando o espaço urbano, como um resgate das tradições rurais que foram obliteradas com a cultura urbana. [...] O fato é que atualmente há uma tendência de valorização da cultura chamada de tradicional, um movimento retrô. [...] Trata-se de um fato que caracteriza os países centrais do capitalismo onde o fenômeno urbano torna-se cada vez mais expressivo e fonte geradora de estresse. Assim, parece que com a influência do modismo country norte-americano estratos da população urbana brasileira, na sua maioria jovem, passam a aderir à referida moda. Os festejos rurais invadem a cidade, onde muitos clubes, alguns já no perímetro urbano convencionalmente estabelecido, se dedicam a bailes country. Esses festejos que tradicionalmente aconteciam em junho - as festas juninas - ganham nova dimensão. Multiplicam-se os espaços para leilóes de gado, feiras e exposições, rodeios e outras atividades de cunho rural. O evento mais conhecido no Brasil é a festa do peão em Barreiros (Rodrigues, 2003, p. 108). 
A complexidade do tema se estende, na observação da autora, sobre o novo "turismo rural de cunho acadêmico", que inclui a hospedagem de turistas em campus universitários e aulas teóricas e práticas dessa modalidade. Ela cita, ainda, a experiência do Movimento dos Trabalhadores Sem Terra (MST), cujos membros alojam congressistas em acampamentos para ministrarem palestras e cursos, que atraem inclusive visitantes de outros países do Cone Sul.

Conforme as Diretrizes para o Desenvolvimento do Turismo Rural (Ministério do Turismo, 2004), que tanto acata o termo turismo rural quanto o de agroturismo, o que importa é que a atividade turística seja cuidada

[...] de modo integrado e participativo, sempre considerando os arranjos produtivos de cada território, a fim de fortalecer os laços comunais e vicinais, reforçar a coesão social, a cooperação produtiva e a valorização dos elementos naturais e culturais, respeitadas as singularidades, com vista aos benefícios para as comunidades (p. 15).

Há tantas concepções do turismo rural, como corrobora Portuguez (2005), quanto há espaços rurais diferentes, o que nos leva a pensar em abordagens e reflexões conforme a linha de observação que nos irá guiar. De qualquer modo, parece fundamental não se precipitar na associação fácil de imagens já conhecidas, tomando-se o cuidado com as necessárias distinções de forma e função, como sugere o autor:

Pensar o meio rural significa lembrar desertos, geleiras, áreas florestadas, montanhas, campos altamente mecanizados, campos cultivados no regime de subsistência, áreas ricas em castelos medievais, áreas onde o camping é a única possibilidade de pernoite, entre muitos outros exemplos. Em outras palavras, não se deve vincular a reflexão sobre o turismo rural com a imagem de ruralidade imediata que comumente se faz a partir do mundo rural que se conhece (p. 579, grifos do autor).

No que se refere à segmentação do turismo, de modo geral, as tendências apontam para a necessidade de revisão de paradigmas diante de um turista diferente do modelo ao qual se acostumaram os destinos receptivos (Panosso Netto e Ansarah, 2009). Em face de tantas nuances que abarcam as reflexões sobre o 
turismo rural, tais tendências parecem fortalecer ainda mais o desafio não só na percepção do perfil dos turistas rurais como sujeitos diversos, mas também, principalmente, em estabelecer novas referências teóricas e práticas no setor.

\section{Considerações finais}

O desenvolvimento de atividades turísticas em espaço rural está associado ao processo de urbanização que ocorre na sociedade e no transbordamento do espaço urbano para o espaço rural, segundo Graziano da Silva (1997). Para esse autor, "novas" formas de ocupação passaram a proliferar no campo, entre elas são destacadas: o conjunto de profissões tidas como urbanas (trabalhadores domésticos, mecânicos, secretárias etc.); moradias de segunda residência; atividades de conservação; áreas de lazer (hotéis-fazenda, fazenda-hotéis, pesque-pague etc.). Essas "novas" atividades demandaram um número crescente de pessoas para dar sustentação à expansão das atividades turísticas em espaço rural.

Diante disso, qualquer abordagem sobre o turismo rural deve considerar, a título de alguma segurança, o espaço como construção social, coletiva, em uma dinâmica que resulte em promoção social e cultural. Nesse aspecto, as dimensões do global e do local precisam ser também apreciadas.

Assim, de posse do entendimento de que os territórios podem ser modificados pela utilização da técnica e de que os espaços são valorizados em razão de fatores políticos, econômicos, sociais e culturais é que podermos refletir sobre a possibilidade de que todos os espaços possam vir a ser do turismo, sem que nenhum espaço turístico venha a ter sentido por si só, sem contexto.

Há que se identificar critérios que possam definir propriedades, empreendimentos e atividades relacionadas ao segmento, mas considerando diferentes níveis de ruralidade, conforme orienta Rodrigues (2000). A partir de um arcabouço nesses termos, pode-se avançar investigando potencialidades locais e regionais sobre o segmento, de tal modo que algumas experiências possam guardar parâmetros de comparação e aprendizagem para novos ensaios.

O turismo em espaço rural se afirma como mais uma alternativa que se coloca para os agricultores familiares venderem sua força de trabalho e complementarem sua renda, reforçando o caráter pluriativo das unidades familiares de produção e sua inserção no processo de produção do espaço. De acordo com Lefebvre (1999), estaríamos sob o signo de uma sociedade urbana, e essa urbanização estruturaria o território, o que Santos (1993) aponta como passa- 
gem da urbanização da sociedade para a urbanização do território. A prática do turismo rural contemporâneo refletiria essa prática, uma vez que os hotéis fazenda, spas rurais e casas de segunda residência se localizam, preferencialmente, próximas às grandes concentrações urbanas.

\section{Referências}

BARRETTO, Margarita. Turismo elegado cultural. Campinas: Papirus, 2000. (Coleção Turismo).

BRITTO, Monique Cristine e FERREIRA, Cássia de Castro Martins. "Paisagem e as diferentes abordagens geográficas”. Revista Geografia, v. 2, n. 1, pp. 1-10, 2011.

BURNS, Peter M. Turismo e antropologia: uma introdução. São Paulo: Choronos, 2002. (Coleção Tours).

CAMPANHOLA, Clayton e GRAZIANO DA SILVA, José. "Panorama do turismo no espaço rural brasileiro: uma nova oportunidade para o pequeno agricultor". In OLIVEIRA, Cássio Garkains de Souza (ed.). Anais do Congresso Brasileiro de Turismo Rural: turismo no espaço rural brasileiro. Piracicaba: FEALQ, 1999.

CUNHA, Licínio. Introdução ao turismo. Lisboa-São Paulo: Editorial Verbo, 2001.

DIRY, Jean-Paul. Les espaces ruraux. 2 ed. Paris: Armand Collin, 2004.

FERRÃO, João. "Relações entre o mundo rural e mundo urbano: evolução histórica, situação actual e pista para o futuro”. EURE, v. 26, n. 78, Santiago, set. 2000.

GRAZIANO DA SILVA, José. “O novo rural brasileiro". Nova Economia, v. 7, n. 1, pp. 43-81, Belo Horizonte, 1997.

JEAN, Yves. Géographies de l'écolerurale: acteurs, réseaux, territories. Paris: Éditions Ophrys, 2007.

LEFEBVRE, Henri. A revolução urbana. Belo Horizonte: Humanitas, 1999.

LOCATEL, Celso D. "Da dicotomia rural-urbano à urbanização do território no Brasil”. Mercator, v. 12, n. 2 (especial), pp. 85-102, set. 2013. 
MARAFON, Gláucio José e RIBEIRO, Miguel Ângelo. "Agricultura familiar, pluriatividade e turismo rural: reflexões a partir do território fluminense". Revista Rio de Janeiro, n. 18-19, jan.-dez. 2006.

MOREIRA, Roberto José. Ruralidades e globalizaçôes: ensaiando uma interpretação. 2 ed., n. 1. Rio de Janeiro: Curso de Pós-Graduação em Desenvolvimento, Agricultura e Sociedade/CPDA, 2002.

MTUR - Ministério do Turismo. Diretrizes para o desenvolvimento do turismo rural no Brasil. Brasília: Ministério do Turismo, 2004.

OMT - Organização Mundial do Turismo. Introdução ao turismo. São Paulo: Roca, 2001.

PANOSSO NETTO, Alexandre e ANSARAH, Marília Gomes dos Reis. "Segmentação em turismo: panorama atual". In e (eds.). Segmentação do mercado turistico: estudos, produtos e perspectivas. Barueri: Manole, 2009.

PIRES, Mário Jorge. Raizes do turismo no Brasil. São Paulo: Manole, 2002.

PIRES, Paulo dos Santos. "A paisagem rural como recurso turístico". In RODRIGUES, Adyr Balastreri (org.). Turismo Rural: práticas e perspectivas. São Paulo: Contexto, 2003. (Coleção Turismo Contexto).

PORTUGUEZ, Anderson Pereira. “Turismo rural”. In TRIGO, Luiz Gonzaga Gooi (ed.) et al. (coeds.). Análises regionais e globais do turismo brasileiro. São Paulo: Roca, 2005.

RAFFESTIN, C. Por uma geografia do poder. São Paulo: Editora Ática, 1993.

REIS, José. "Observar a mudança: o papel dos estudos rurais". Conferência pronunciada no $1 .^{\circ}$ Congresso de Estudos Rurais, Vila Real-Portugal, 2001.

RODRIGUES, Adyr A. Balastreri. Turismo rural: práticas e perspectivas. São Paulo: Contexto, 2003. (Coleção Turismo Contexto).

RUA, João. "Urbanidades no rural em um trecho da região serrana fluminense: a rodovia Teresópolis-Nova Friburgo". In I Encontro de Grupos de Pesquisa - agricultura, desenvolvimento regional e transformações sócio-espaciais, Rio de Janeiro, 2005. 
. "Urbanidades no rural: o devir de novas territorialidades". Campo-território: Revista de Geografia Agrária, v. 1, n. 1, pp. 82-106, Uberlândia, 2006. Disponível em: <www.campoterritório.ig.ufu.br>.

SANTOS, Milton. Por uma geografia nova. São Paulo: Hucitec, Edusp, 1978. . A urbanização brasileira. São Paulo: Hucitec, 1993. . A natureza do espaço: técnica e tempo, razão e emoção. São Paulo: Hucitec, 1996.

SILVA, José Borzacchiello. "Discutindo o rural e o urbano". Revista ANPEGE, v. 7, n. 8, pp. 3-11, ago.-dez. 2011.

SILVEIRA, Marcos Aurélio Tarlombani. "Política de turismo: oportunidades ao desenvolvimento local”. In RODRIGUES, Adyr Balastreri (org.). Turismo Rural:práticas eperspectivas. São Paulo: Contexto, 2003. (Coleção Turismo Contexto).

TALAVERA, Agustín Santana. "O rural como produto turístico: algo de novo brilha sob o sol”. In SERRANO, Célia et al. (orgs.). Olhares contemporâneos sobre o turismo. Campinas: Papirus, 2000. (Coleção Turismo).

TEIXEIRA, Márcio Antônio e LAGES, Vinícius Nobre. “Transformações no espaço rural e a geografia rural: ideias para discussão”. Rev. Geogr., n. 14, pp. 9-33, São Paulo, 1997.

TULIK, Olga. Turismo rural. São Paulo: Aleph, 2003. (Coleção ABC do Turismo).

VERBOLE, Alenka. "A busca pelo imaginário rural”. In ALMEIDA, Mário Riedl et al. (org.). Turismo rural: tendências e sustentabilidade. Santa Cruz do Sul: EDUNISC, 2002.

WOODS, Michael. Rural Geography. London: SAGE. 2005.

."Engagingthe global countryside:globalization, hibridity and there constitution of rural place". Progress in Human Geography, v. 31, n. 4. pp. 485-507, 2007. 


\section{A dimensão espacial da atividade turística no território fluminense}

Nathan da Silva Nunes

Miguel Angelo Ribeiro

\section{Introdução}

Este artigo tem como proposta analisar a dimensão espacial do turismo no estado do Rio de Janeiro, visto que tal atividade tem importância econômica destacada para diversos municípios fluminenses. A seleção do recorte espacial ocorreu em virtude da observação de características que tornam o referido estado singular, visto que é possível identificar a prática de atividades relacionadas a diversas tipologias turísticas.

É válido ressaltar que estatísticas recentes apontam para um crescimento mundial dos fluxos relacionados ao turismo, com cerca de 1,2 bilhão de pessoas deslocando-se pelo planeta em 2015.

Nesse contexto, podemos pontuar que o estado do Rio de Janeiro caracteriza-se por apresentar enorme diversidade de situações topográficas e climáticas, bem como grande variedade de condições histórico-culturais (Ribeiro, 2003). Assim, a atividade turística se reveste de grande importância como fator de interiorização do desenvolvimento econômico e social, considerada atualmente uma expressão das mais autênticas do processo de globalização. $\mathrm{O}$ fenômeno do turismo expande-se em âmbito mundial até as regiões mais remotas, não sendo desconsiderado nenhum território. E, sob esse aspecto, o Brasil encontra-se inserido nessa economia globalizada por meio da atividade do turismo não só em decorrência de suas mais diversas paisagens, entre elas, as tropicais, como também em seus diferentes aspectos culturais e históricos, tornando-se, na América Latina, uma das principais áreas receptoras desses fluxos (Ribeiro, 2003). 
O Brasil recebeu em 2015 e 2016, aproximadamente, 6,0 e 6,6 milhões de turistas estrangeiros, respectivamente, sendo que mais de 1,5 milhão (em ambos os anos) teve como destino o território fluminense, como indicado pelo Ministério do Turismo. Por isso, o estado do Rio de Janeiro (mapa 1) é uma das unidades federadas que apresenta importância para a promoção do turismo brasileiro, atividade esta que merece destaque no contexto do desenvolvimento econômico de nosso estado.

Em nível nacional, o Rio de Janeiro é o segundo ente federativo, quando tratamos do número de viagens a negócio. Porém, está na liderança quando a motivação do deslocamento é o lazer, destacando-se não apenas a capital, mas também alguns municípios do interior, como Armação dos Búzios, Cabo Frio, Angra dos Reis e Paraty.

Mapa 1: Regiões de governo do estado do Rio de Janeiro

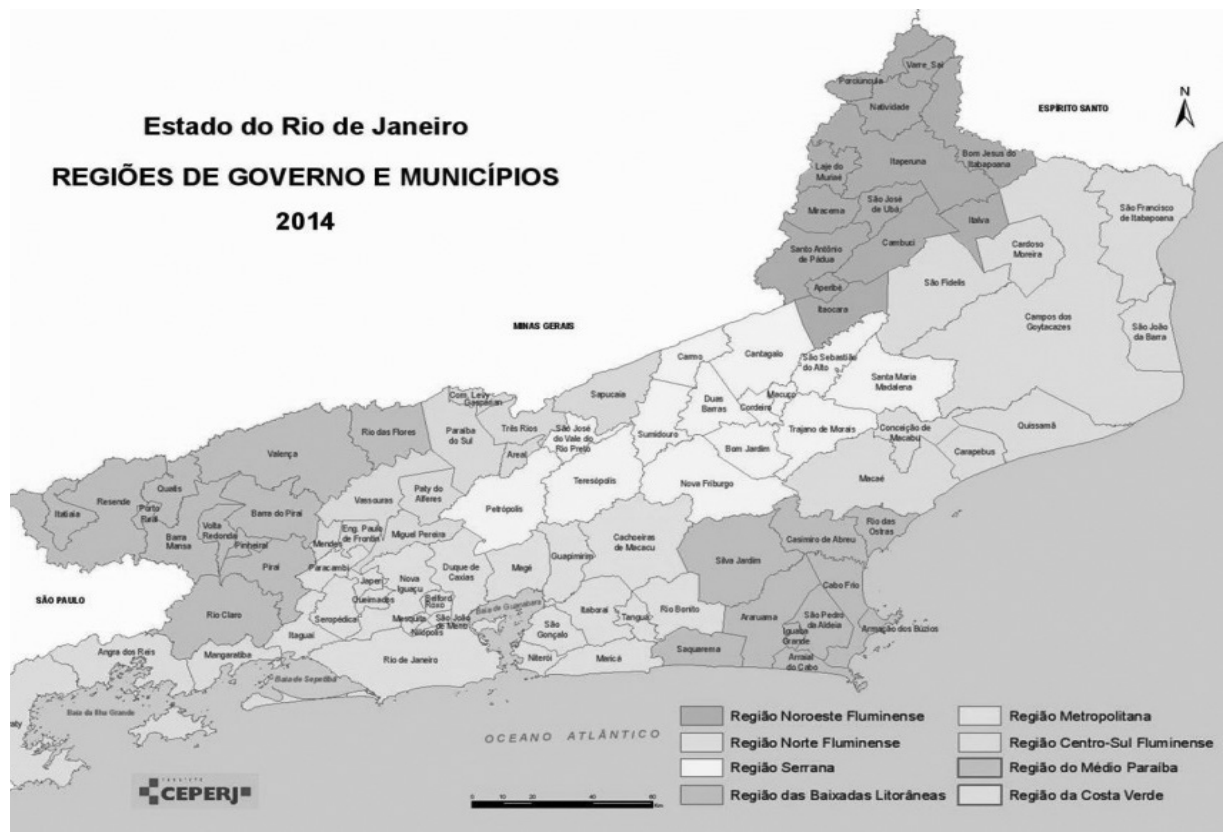

Fonte: Centro Estadual de Estatísticas, Pesquisas e Formação de Servidores Públicos do Rio de Janeiro, 2014. 
Tais resultados ratificam o papel do estado do Rio de Janeiro como uma das principais unidades receptoras de turistas nacionais e internacionais, apresentando importância para a promoção do turismo brasileiro.

Para que possamos atender aos desafios propostos, este capítulo encontra-se estruturado em três partes. A primeira envolve as condicionantes para o desenvolvimento das atividades turísticas no território fluminense, destacando-se os elementos físicos ou naturais, o elemento histórico e as atividades econômicas, o papel dos transportes e as políticas de turismo. Na segunda seção, procura-se discutir a institucionalização do turismo no estado, partindo da década de 1960, quando são criadas as primeiras empresas públicas voltadas para o setor, abordando ainda os planos, as tipologias e as classificações oficiais desenvolvidas para os municípios fluminenses. Por fim, na terceira seção, o foco será analisar e descrever as atividades turísticas em alguns municípios do estado, sendo selecionados aqueles em que o setor apresenta maior representatividade no contexto nacional, segundo classificações do Ministério do Turismo.

\section{Condicionantes para o desenvolvimento das práticas turísticas nos municípios fluminenses}

Para que possamos realizar uma análise acerca dos principais aspectos da atividade turística verificados no estado do Rio de Janeiro, é preciso apontar as condicionantes que viabilizam tal fenômeno. Porém, é necessário, em um primeiro momento, apresentar concepções e definições acerca do lazer, pois este relaciona-se intimamente com o turismo.

Para tanto, Menoia (2000) destaca o caráter de oposição entre o conceito de lazer e o de trabalho, visto que a redução na carga horária deste último tem propiciado mais tempo livre para o homem, um ser lúdico. Para Barbosa e Silva (2011), por sua vez, data do período pós-Revolução Industrial o início das discussões a respeito do lazer, sucedendo aquelas que tinham como objeto principal de análise o ócio, o não trabalho. Tais debates estavam inseridos no contexto marxista e sua crítica ao sistema capitalista.

Há uma série de conceituações para o referido termo, considerando, em sua maioria, a dimensão temporal, a atividade, a função, a importância e a maneira como é usufruído pelo homem (Menoia, 2000). A partir da concepção do sociólogo francês Dumazedier, Menoia (2000, p. 11) faz considerações sobre o lazer. 
Segundo o autor, o lazer completo possui caráter liberatório, de livre escolha; caráter desinteressado, sem fim lucrativo; caráter hedonístico, de satisfação; caráter pessoal, onde as expectativas superam as necessidades. Classifica então o lazer em quatro tipos, conforme o tempo disponível: lazer do fim do dia, do final de semana, do final do ano e do fim da vida.

Visando a relacionar tal conceito à temática proposta para este capítulo, utilizaremos a abordagem de Barbosa (2011, p. 4) para associá-lo ao turismo, pois a autora entende que o lazer está vinculado à liberação e ao prazer, podendo apresentar três funções distintas, que seriam: "a do descanso (libera-se da fadiga); do divertimento, recreação e entretenimento (liga-se à fadiga, e esta, ao tédio) e do desenvolvimento (desenvolve a personalidade que depende de autonomia do pensamento e da ação cotidiana)".

Após apresentar o lazer a partir do turismo, iniciaremos a análise de tais atividades de forma mais abrangente, destacando, em um primeiro momento, que não podem ser pensadas sem as bases geográficas e, nesse contexto, podemos distinguir três condicionantes que influenciam seu desenvolvimento em território fluminense. Tais condicionantes estão intimamente relacionadas. São elas: a) o elemento físico ou natural; b) o elemento histórico e as atividades econômicas; e c) o papel dos transportes.

\section{O elemento fisico ou natural}

O quadro físico fluminense apresenta-se muito diversificado, em contraponto à limitada extensão territorial (Cide, 1997). Nesse sentido, o estado do Rio de Janeiro se configura como uma sucessão de paisagens, cujo alinhamento segue, aproximadamente, a direção geral SW-NE, dominada pela disposição do relevo, que condiciona, em grande parte, a variedade do clima e da cobertura vegetal, entre outros elementos. Sendo assim, distinguem-se como principais unidades físicas: o trecho litorâneo, o conjunto montanhoso e o planalto ondulado até o Vale do Paraíba, como apontou, grosso modo, Ribeiro (2003).

I - O trecho litorâneo abrange a linha costeira e a região das baixadas, em direção à parte setentrional do estado, constituído por lagoas e cordões litorâneos, com vegetação de restinga. Parte dessa área integra 
a região turística denominada Costa do Sol, iniciando-se nos limites da área Metropolitana (município de Maricá) até o município de Rio das Ostras; e a parte meridional, de constituição rochosa e muito recortada em baías e enseadas, prolongando-se até o município de Parati. Nessa unidade física, a modalidade de turismo mais desenvolvida é a do aproveitamento das praias e das práticas náuticas, apesar de atualmente novas modalidades de turismo serem utilizadas, como a histórico-cultural, a rural e o ecoturismo.

II - O conjunto montanhoso da Serra do Mar, representado pela frente escarpada e seu reverso, atravessando quase todo o estado, com altitudes de até 2.000 metros (Serra dos Órgãos), em alguns pontos, é caracterizado por temperaturas mais amenas, quando comparado com as demais unidades físicas, imprimindo características peculiares às diferentes modalidades turísticas. Essa porção é conhecida como Região Serrana.

III - Por fim, distingue-se o planalto ondulado, que perde altitude até o Vale do Paraíba do Sul, sendo que o rio de mesmo nome representa o traço mais marcante nessa paisagem, cortando o território fluminense de sul para norte e formando uma depressão encaixada entre as escarpas das Serras do Mar e da Mantiqueira, esta exibindo o paredão do Pico das Agulhas Negras, com aproximadamente $2.800 \mathrm{~m}$ de altitude, muito aproveitado para diferentes modalidades de turismo.

Esse quadro físico constitui-se em suporte material para a organização econômica e social fluminense, estando diretamente associado ao desenvolvimento da atividade do turismo e exercendo influência na produção de lugares para o consumo.

\section{O elemento histórico e as atividades econômicas}

O elemento histórico e as atividades econômicas são importantes condicionantes para o desenvolvimento da atividade turística. Nesse sentido, de modo geral, podemos analisar a ocupação do atual estado do Rio de Janeiro pelos portugueses a partir do século XVI. 
Esse século foi marcado pela descoberta da faixa litorânea do Estado, pela expedição em que tomou parte Américo Vespúcio (1501-02), sendo que, em 1503, foi instalada uma feitoria na futura cidade de Cabo Frio, enquanto em 1565 fundou-se a cidade do Rio de Janeiro. Assim, formas pretéritas criadas no século XVI ainda persistem nesses espaços e são testemunhas importantes para a preservação da memória e da cultura.

Esse período foi marcado pela Coroa Portuguesa com a ocupação do litoral, como defesa e conquista da terra (Rahy, 1999), destacando-se a importância do sítio, ou seja, do local no qual estabeleceram-se as futuras cidades, geralmente ocupando a entrada de baías, rios etc., com a presença de inúmeras fortificações, como as encontradas na Baía de Guanabara.

O século XVII foi marcado pelas experiências agrícolas vinculadas à produção de cana-de-açúcar e seus engenhos no Norte Fluminense, ou mesmo nos arredores da capital. Essa atividade marca a paisagem da região até os dias atuais, encontrando-se fazendas dos antigos barões do açúcar e usinas, enquanto na área metropolitana, pelas grandes transformações ocorridas, poucos vestígios foram deixados na paisagem.

No século XVIII, com a descoberta das reservas auríferas das Minas Gerais, a organização do povoamento fluminense foi profundamente alterada. A exploração do ouro influenciou indiretamente na ocupação do território. Concomitantemente à exploração aurífera nas Minas Gerais, nos primeiros anos desse século, a cana-de-açúcar atingiu definitivamente a baixada campista, na porção norte do Estado.

Quanto à atividade aurífera, as cargas do referido metal desciam do planalto das Minas Gerais em lombos de burros, na direção de Parati (Caminho Velho) e eram conduzidas pelo mar até o Rio de Janeiro (Mota e Lopez, 2016).

O Rio de Janeiro tornou-se rapidamente o principal porto e a mais ativa cidade do país, ao mesmo tempo, a atividade aurífera contribuiu para o aparecimento de vilas - embrióes para futuras cidades - que serviam de passagem para o interior, como Vassouras, Paraíba do Sul e Paty do Alferes, entre outras (Rahy, 1999).

No século XVIII, do ponto de vista histórico e político, merece destaque a transferência da sede do governo colonial de Salvador para a antiga Província do Rio de Janeiro (1763), em decorrência do comércio do ouro das Minas Gerais, além das condições geográficas. 
Cumpre lembrar que, no período compreendido entre os séculos XVII e XVIII, os portos tiveram importância fundamental na história econômica fluminense, primeiramente com o transporte de cana-de-açúcar e, logo em seguida, com o ouro.

O início do século XIX foi marcado, primeiramente, pela extinção do ouro das Minas Gerais (decadência da mineração), enquanto a cana-de-açúcar voltou a concentrar, mas por pouco tempo, todas as atenções.

Outro fato histórico e político importante para o atual estado do Rio de Janeiro e, mais diretamente, para a cidade do Rio de Janeiro, foi a chegada da Corte Portuguesa, em 1808, que afetou a estrutura organizacional da urbe carioca. Em 1834, essa cidade separou-se de sua província, e a capital imperial foi elevada à condição de Município Neutro, enquanto a cidade de Niterói tornou-se capital da Província Fluminense, em 1835 (Ribeiro, 2001).

À medida que o Império se consolidava, surgia um novo produto-rei na economia fluminense: o café. Essa nova cultura de base exportadora começou o seu trajeto na cidade do Rio de Janeiro, mais precisamente no Maciço da Carioca, nas encostas de Jacarepaguá, além dos Maciços da Pedra Branca e do Mendanha. Foi plantado em várias áreas do território fluminense, embora não tenha obtido o resultado esperado, em decorrência da declividade do terreno e das condições climáticas. Mas, a maior expressão cafeeira da antiga província iria ocorrer quando, a partir do Mendanha, a rubiácea atingiu São João Marcos (parte do atual município de Rio Claro), Piraí e Resende, chegando, portanto, ao Vale do Paraíba, em seu trecho médio.

O café, no Médio Paraíba Fluminense, teve seu plantio expandido para várias direções, sendo cultivado ao norte em Entre Rios (atual município de Três Rios), seguindo para Nova Friburgo e Cantagalo, na Região Serrana, terminando sua expansão em Itaocara e São Fidélis e seguindo a direção da Zona da Mata Mineira e do Espírito Santo.

As encostas foram ocupadas com cafezais, e o fundo dos vales, com as sedes das fazendas e instalações de beneficiamento do produto. Atualmente, muitas dessas fazendas, principalmente aquelas localizadas no Médio Paraíba, nos municípios de Vassouras, Valença, Paraíba do Sul, entre outros, estão sendo resgatadas para a atividade turística, a partir de um processo de refuncionalização.

Os elementos históricos na paisagem, muitos deles, frutos das atividades econômicas desenvolvidas em território fluminense, representam importantes 
marcos no processo de ocupação, e que hoje podem ser resgatados como elementos culturais e da memória de um povo, constituindo-se em vetores das diferentes modalidades de turismo.

Tais elementos históricos tiveram sucesso graças ao papel dos transportes, e sua evolução, graças às técnicas que foram sendo desenvolvidas.

\section{O papel dos transportes}

Os transportes são importantes aliados no desenvolvimento da atividade do turismo. Esses sistemas de engenharia são relevantes no sentido de promoverem a rapidez dos deslocamentos e das comunicações.

Para o estado do Rio de Janeiro, tais sistemas tiveram papel preponderante no tocante à expansão do turismo interno, primeiramente com a difusão das estradas de ferro, a partir de 1854, impulsionadas com o esplendor da cultura cafeeira, a partir de 1870 , e principalmente com o advento das rodovias, iniciadas no final da década de 1940.

As rodovias tiveram papel vital na expansão do turismo em território fluminense, concretizando-se, notadamente, a partir da década de 1970, com a construção da Ponte Presidente Costa e Silva, que liga as duas principais cidades do estado, Rio de Janeiro e Niterói; a abertura da BR-101; além da duplicação das rodovias Presidente Dutra (BR-116) e Washington Luís (BR-040), ligando a capital do estado às cidades mineiras de Juiz de Fora e Belo Horizonte.

Com a implantação da BR-101 em território fluminense, além da construção da Ponte Rio-Niterói, concretizada em 1974, a tendência foi haver uma expansão da atividade turística em direção ao litoral sul (Costa Verde) e ao litoral norte (Costa do Sol). Esses são dois grandes vetores de expansão do turismo litorâneo, secundados pela BR-116 (Rodovia Presidente Dutra), que corta a região do Vale do Paraíba.

A duplicação e o melhoramento desses eixos de transporte vieram a contribuir de forma positiva para o desenvolvimento da atividade turística em terras fluminenses, principalmente para os municípios localizados externamente à metrópole, tanto os litorâneos como os do interior. Tal fato, associado aos outros elementos, como o quadro natural diversificado, e aos condicionantes históricos, ensejou a difusão da atividade turística por alguns municípios fluminenses, tornando-os verdadeiros lugares para o consumo.

Sendo assim, no próximo segmento, relacionaremos a influência dos elementos apresentados com os tipos de turismo praticados na região das Baixadas 
Litorâneas fluminense, objetivando caracterizar essa atividade a partir das estratégias e políticas adotadas pelo poder público.

\section{Institucionalização turística, tipologias e categorização dos municípios do estado do Rio de Janeiro}

A atividade turística apresenta grande destaque quando tratamos do estado do Rio de Janeiro, muito em razão da fama e do simbolismo que tem a capital, com pontos turísticos conhecidos mundialmente, como o Pão de Açúcar, o Cristo Redentor, a praia de Copacabana, o estádio do Maracanã, entre tantos outros. De acordo com Fratucci (2005, p. 82), “o Rio de Janeiro sempre foi, e continua sendo, o estado brasileiro onde a atividade turística apresenta dimensões mais marcantes, tanto para a sua economia, quanto para sua estrutura sociocultural". Porém, a atividade também apresenta dinamicidade no interior, o que é destacado por esse autor, quando diz que o estado

tem no turismo um dos suportes de desenvolvimento mais importante, apresentando sobreposto ao seu território uma rede bastante ampla de nós/lugares turísticos, interligada por uma extensa malha de rodovias, hidrovias, ligaçôes aéreas (a malha ferroviária existente praticamente não é utilizada pelo sistema turístico) e de uma complexa rede de comunicaçôes.

O discurso oficial corrobora com o autor, tendo em vista que o Caderno de turismo do estado destaca a atividade turística como influenciada pela vasta diversidade de paisagens, características topográficas e climáticas, além das singularidades culturais encontradas no estado do Rio de Janeiro, para em seguida alertar sobre a importância que representa para alguns municípios e para o estado de maneira geral, destacando que tais práticas muitas vezes surgem de potencialidades até então pouco exploradas em características peculiares a cada município (Gomes, 2010).

É na década de 1960 que tem início o ordenamento territorial a partir do turismo no estado do Rio de Janeiro, visto que neste período começa a haver uma preocupação institucional em relação à atividade, com a criação do Instituto Brasileiro de Turismo (atual Embratur), em nível nacional, e da Companhia de Turismo do Estado do Rio de Janeiro (Flumitur), segundo Fratucci (2005). Já 
nos anos 1970, começa a ser mais evidente o processo de interiorização da atividade, muito em virtude da fusão dos estados da Guanabara e do Rio de Janeiro, em 1975, o que ocasionou a transferência da sede da Flumitur de Niterói para o Rio de Janeiro, passando a desenvolver ações que tinham como foco principal o interior, visto que o turismo da capital era gerido pela Riotur (Fratucci, 2005). Buscando evidenciar tal preocupação dos agentes públicos no desenvolvimento turístico do interior, selecionamos a definição de Cabo Frio como centro turístico nacional, de acordo com a Embratur, na década de 1980. Nessa mesma década, foi desenvolvido o Plano Indutor de Investimentos Turísticos na Região dos Lagos, do governo do estado do Rio de Janeiro, com apoio do governo da Catalunha. Fratucci (2005, p. 91) tece considerações a respeito das razões para a elaboração e os objetivos do plano.

\begin{abstract}
A justificativa para a elaboração desse plano estava calcada em um diagnóstico do turismo brasileiro da época, que apontava para o fato de, apesar da forte demanda potencial (nacional e internacional) existente, o Rio de Janeiro não oferecer um produto turístico coerente e compatível com as exigências do mercado. Segundo relatórios da época, esse desajuste era causado pela ausência de uma política de turismo específica para um segmento de mercado, o que demonstrava a ausência de um produto turístico altamente qualificado e competitivo internacionalmente. A escolha da Região dos Lagos do Rio de Janeiro baseou-se na sua proximidade com a cidade do Rio de Janeiro e com o Aeroporto Internacional (média de $60 \mathrm{~km}$ ); nas características fisiográficas locais: grande extensão do litoral, clima tropical, baixo índice pluviométrico e inverno com temperaturas médias em torno de $20^{\circ} \mathrm{C}$; na sua topografia ideal para implantação de campos de golfe e, nas características culturais dos seus centrosurbanos.
\end{abstract}

À época, foram elaboradas diversas propostas para a aplicação do plano, porém uma série de dificuldades políticas o inviabilizaram, como alterações nas legislações municipais quanto ao uso do solo, a ausência de recursos financeiros suficientes e a eleição estadual, que colocou no poder um novo governo (Fratucci, 2005).

Silva (2008, p. 272) ressalta os resultados obtidos recentemente pelos municípios do Rio de Janeiro que têm o turismo como principal atividade, pois 
"há algum tempo podem ser relacionados entre os que apresentam as maiores taxas de crescimento, o que, de maneira geral, só confirma uma tendência mundial nesse sentido". Porém, há nesse estado uma variedade considerável de tipologias relacionadas ao turismo, o que contribui decisivamente para o crescente número de visitantes, visto que há opções para os mais variados públicos.

Cumpre fazer referência que, além das políticas na escala nacional e estadual, não podemos deixar de mencionar as respectivas Secretarias Municipais de Turismo ou órgãos similares. Essas secretarias desenvolvem políticas específicas com relação aos atrativos e atividades que conferem singularidades aos municípios turísticos, incentivando, por meio do marketing, calendários e folders, a promoção da atividade em tela. Podemos exemplificar, na Região das Baixadas Litorâneas, o município de Armação dos Búzios, que procura difundir uma imagem relacionada aos aspectos da natureza, especialmente os ambientes de praia. Outro exemplo é a Costa Verde, que difunde uma imagem de paraíso em seus prospectos como uma forma de "vender" esse trecho do litoral sul fluminense com suas belezas naturais.

Para inserir uma discussão a respeito das tipologias da atividade turística no estado do Rio de Janeiro, cabe recorrer a Ribeiro (2003), que destaca três fatores que acabam condicionando o desenvolvimento dessa atividade nos municípios fluminenses, que seriam suas características físicas ou naturais, os elementos culturais formados a partir da história e a atuação fundamental dos transportes, alicerçado nas rodovias, como já abordado na primeira parte deste capítulo.

Tratando diretamente dos modelos desenvolvidos em território fluminense, serão utilizadas como referências as tipologias indicadas por Ribeiro (2003) e as classificações de áreas turísticas do estado do Rio de Janeiro, segundo o Núcleo de Estudos de Geografia Fluminense (NEGEF, 2010).

Ribeiro (2003) utiliza o Guia Quatro Rodas da Editora Abril (1999) para fundamentar sua argumentação a respeito das localidades classificadas como de função turística, utilizando ainda, para a elaboração da tipologia, outros dois elementos, a saber: as atrações e os diferentes tipos de hospedagem. Após considerar tais fatores, o autor elaborou a tipologia a partir de cinco grandes tipos, acrescendo ainda as localidades de apoio. Os tipos seriam: 1 - Litorânea; 2 - Histórica/Rural; 3 - Rural/Ecológica/Aventura; 4 - Estância/Rural; e 5 - Cultural/Rural. Cabe ainda ressaltar que os tipos 1 e 3 apresentam subtipos 
(quadro 1). Essa tipologia, apesar de ser do final do século XX e, por isso, precisar de novos ajustes, ainda tem validade.

O Ministério do Turismo (2015), por sua vez, categorizou os municípios fluminenses de acordo com o desempenho econômico de cada um destes no setor, classificando-os de "A" a "E". Por meio do quadro 2, procuramos destacar aqueles que apresentaram resultados mais expressivos, evidenciando a consolidação do turismo como importante atividade econômica.

Quadro 1: Tipologia das funções turísticas no estado do Rio de Janeiro

\begin{tabular}{|c|c|}
\hline TIPOS (FUNÇÕES) & SUB-TIPOS \\
\hline 1- Litorânea & $\begin{array}{c}\text { 1.1- Diversificada } \\
\text { 1.2- Praia-Náutica/Rural } \\
\text { 1.3- Praia-Náutica } \\
\text { 1.4- Praia-Náutica/Histórica }\end{array}$ \\
\hline 2- Histórica/Rural & 3.1- Diversificada \\
3.2-Rural \\
3- Rural/Ecológica/Aventura & 3.3-Rural/Ecológica/Aventura \\
\hline 4- Estância/Rural & \\
\hline 5- Cultural/Rural & \\
\hline 6- Apoio ao Turismo & \\
\hline
\end{tabular}

Fonte: Guia Quatro Rodas, Brasil. São Paulo: Editora Abril, 1999. Elaborado por RIBEIRO, Miguel Angelo, 20002001. 
Quadro 2: Municípios do estado do Rio de Janeiro inseridos na categoria "A" na categorização turística do Brasil ${ }^{1}$

\begin{tabular}{|c|c|}
\hline Município & Região Turística \\
\hline Angra dos Reis & Costa Verde \\
\hline Armação dos Búzios & Costa do Sol \\
\hline Cabo Frio & Costa do Sol \\
\hline Paraty & Costa Verde \\
\hline Rio de Janeiro & Metropolitana \\
\hline
\end{tabular}

Fonte: Ministério do Turismo, 2015. Elaborado por Nunes (2016).

A partir do quadro 2, Costa (2010, p. 82) afirma algo já diagnosticado, que a sociedade atual tem nos ambientes naturais os principais polos de atração turística. Prossegue analisando especificamente a praia, visto que, segundo ele, esta

é potencialmente turística por dois motivos básicos: a segurança que esse ambiente confere, com suas reentrâncias e o seu imenso e belo horizonte, que suscita nos seres humanos o sentimento de aventura. Importante ressaltar que a praia também permite uma fusão entre atividades econômicas e recreativas, portanto constitui também um ambiente de fixação populacional.

Após a apresentação das funções turísticas e da categorização dos municípios do estado, no próximo segmento discutiremos o turismo a partir de municípios específicos, evidenciando aspectos relacionados à inserção da atividade e do cenário verificado atualmente.

1 Instrumento elaborado pelo Ministério do Turismo para identificar o desempenho econômico no setor para os municípios que constituem o Mapa do Turismo Brasileiro. A categoria "A" representa os municípios com maior fluxo turístico e maior número de empregos e estabelecimentos formais no setor de hospedagem. 


\section{O papel do turismo nos municípios de Angra dos Reis, Paraty, Armação dos Búzios, Cabo Frio e Rio de Janeiro ${ }^{2}$}

Buscando finalizar este capítulo sobre a dimensão espacial da atividade turística no estado do Rio de Janeiro, abordaremos a temática a partir dos municípios inseridos na categoria $\mathrm{A}$ da classificação do Ministério do Turismo, visto que estes são os de maior destaque na escala nacional, conforme variáveis indicadas na nota de rodapé 1 deste capítulo.

No caso de Angra dos Reis, destacamos o processo de ocupação do território que atualmente delimita o município, extremamente vinculado ao processo de colonização do país, com a chegada dos portugueses em seu litoral, em um primeiro momento, e posterior ocupação do interior. Em virtude das condições propiciadas pelo sítio, a denominada Baía da Ilha Grande exerceu importante função portuária para escoamento de ouro vindo de Minas Gerais. Posteriormente, o município teve na produção cafeeira sua principal atividade econômica.

No final dos anos 1970, Angra dos Reis foi escolhida como sede de importantes projetos, como ressalta Corrêa (2010), exemplificados o estaleiro Verolme e as Usinas Nucleares Angra I e II, contrastando com a atividade turística, empreendimento que proporcionou a chegada de fluxos cada vez maiores ao município da Costa Verde fluminense, com a construção da Rodovia Rio-Santos na referida década.

Tratando dos elementos angrenses atrativos aos turistas, Corrêa (2010, p. 118) aponta que

Angra dos Reis é internacionalmente conhecida por seus recursos naturais, como as 365 ilhas e as duas mil praias exaustivamente mencionadas em sites e panfletos encontrados em estabelecimentos turísticos do município e de outras localidades. A condição atribuída de paraíso natural, assim como a ideia construída acerca de sua vocação turística se apresentam como alguns dos argumentos que impulsionam o setor de turismo na localidade.

2 A ordem dos municípios corresponde às Regiões de Governo da Costa Verde (Angra dos Reis e Paraty), das Baixadas Litorâneas (Armação dos Búzios e Cabo Frio) e o município do Rio de Janeiro, núcleo da Região metropolitana. 
Para além do distrito sede, destaca-se também o distrito de Ilha Grande. Nas palavras de Costa (2012, p. 104),

o turismo se aproveita da beleza cênica da Ilha Grande para permanecer, ainda hoje, como principal atividade econômica deste distrito fluminense. A Ilha Grande segue a orientação turística do seu município de origem, Angra dos Reis, que é pautada na concretização do ambiente náutico.

Entretanto, é necessário ressaltar o caráter segregador do turismo, nesse caso, visto que é possível observar o desenvolvimento da atividade em áreas específicas da ilha, com a desvalorização de áreas outrora importantes economicamente, como aquelas ocupadas por população caiçara (Costa, 2012).

$\mathrm{Na}$ mesma região de governo, a Costa Verde, está situado o município de Paraty. O caso desse município reflete o cenário verificado em diversos outros no Brasil onde o turismo apresenta-se como responsável por transformações espaciais que afetam significativamente a sociedade.

Paraty, assim como Angra dos Reis, no século XVII, serviu como entreposto para escoamento aurífero, posteriormente exerceu a mesma função para a produção cafeeira. Após tais atividades econômicas, o município retornou, no fim do século XX, ao grande circuito da economia brasileira por meio do turismo, conforme destaca Silva (2008). Ainda segundo esse autor, a atividade ocasionou inúmeras transformações no município, notadamente no que tange à especialização de serviços, restaurantes e pensões.

A primeira leva de turistas em Paraty era composta pelos chamados hippies, que praticavam o chamado turismo "mochileiro", caracterizado por acampamentos ou hospedagens de baixo custo. Porém, Silva (2008) afirma que a dimensão do turismo nesse município da Costa Verde é alterada na década de 1970, com a chegada da classe média a Paraty, facilitada pela abertura da Rodovia Rio-Santos.

Atualmente, a Secretaria de Turismo de Paraty aponta um calendário anual bastante diversificado (figura 1) para atender diferentes segmentos de visitantes, destacando-se como ponto alto a FLIP (Festa Literária Internacional de Paraty), que ocorre no mês de julho, e o Festival da Cachaça, Cultura e Sabores de Paraty. 
Figura 1: Calendário anual de eventos de Paraty

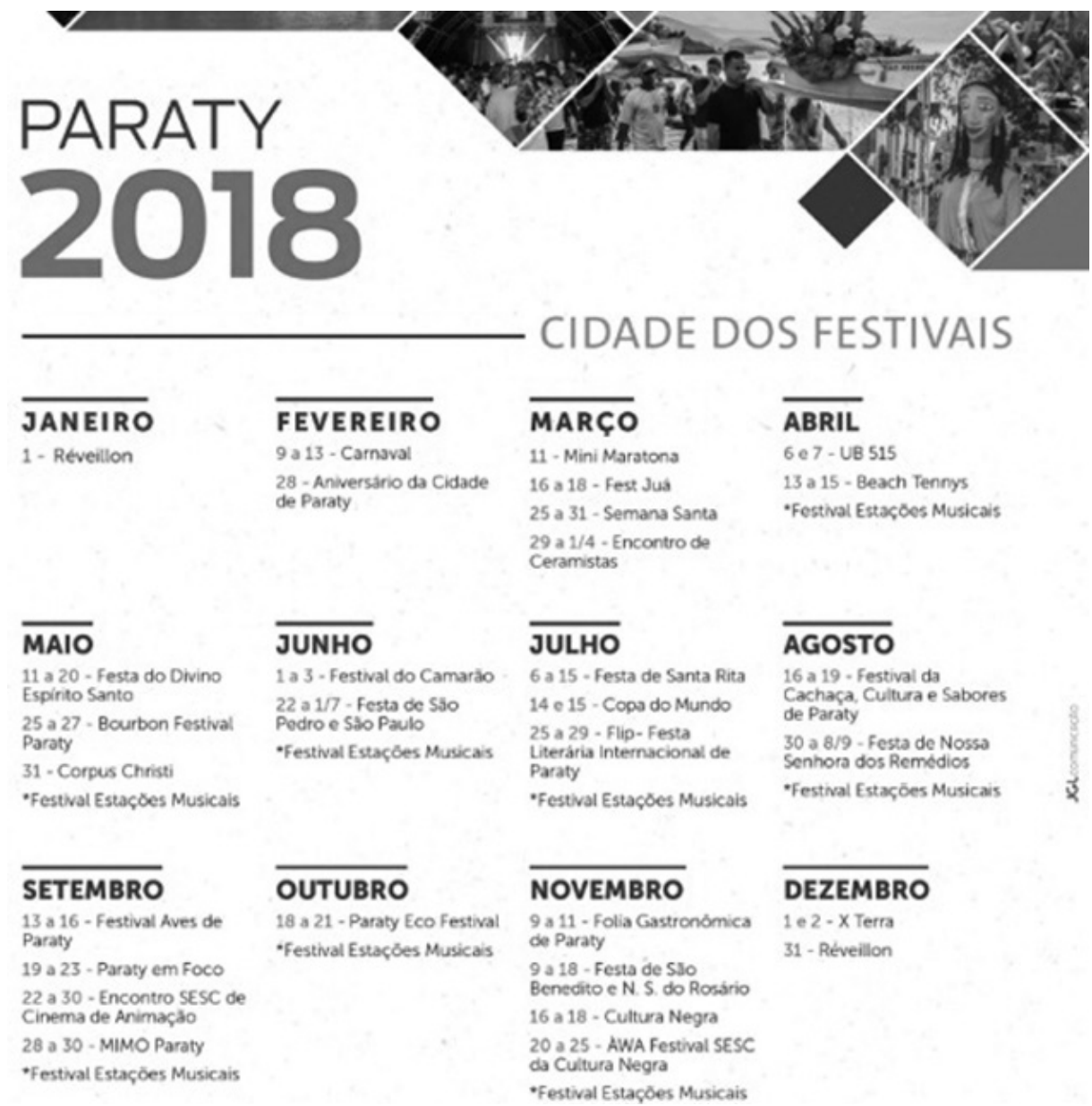

Fonte: Secretaria de Turismo de Paraty, 2018.

Para concluir a abordagem acerca de Paraty, é fundamental regressar à década de 1950, quando seu conjunto histórico foi tombado pelo Instituto do Patrimônio Histórico e Artístico Nacional. A beleza arquitetônica característica do Brasil colonial atrai até os dias atuais importantes fluxos turísticos, além de seus parques, reservas ecológicas e praias.

Quanto a Armação dos Búzios, esta possui história mais recente como município emancipado, mas o processo de ocupação de seu território é extremamente antigo, visto que, antes da chegada dos portugueses, já habitavam seu 
território tribos indígenas. Após a inserção portuguesa, o atual município de Armação dos Búzios verificou uma exploração econômica vinculada à atividade do pau-brasil. Posteriormente, o século XVIII foi marcado pela pesca de baleias na sua enseada, prática que perduraria até 1767 , quando a presença do animal já era rara.

No que diz respeito ao turismo, o município é conhecido internacionalmente, tendo a década de 1960 como marco inicial do início do desenvolvimento mais destacado da atividade turística, em razão da presença da atriz francesa Brigitte Bardot na então vila de pescadores ainda pertencente ao município de Cabo Frio (Nunes, 2017).

Atualmente, a atividade é a de maior destaque na economia desse município localizado nas Baixadas Litorâneas, sendo valorizadas pelos turistas, especialmente, suas praias, diretamente responsáveis pela sua classificação na categoria A do Ministério do Turismo, confirmando a relevância da atividade para sua economia, bem como a expressividade municipal não apenas nos contextos regional e estadual, mas também em âmbito nacional.

Com base no trabalho de campo realizado no ano de 2016, foi possível verificar uma busca pela manutenção do perfil turístico municipal, por meio da atuação dos agentes promotores, sejam eles oriundos do setor público ou da esfera privada. Há uma tentativa de romantizar os atrativos/paisagens do município, pela associação entre linguagem e imagem na criação de representações que cativem o observador. Frases como "a natureza convida você e sua família para um encontro inesquecível" e "desfrute dos pequenos paraísos iluminados pelo sol e bordados pelo mar" são acompanhadas de imagens fotográficas diversas, mas onde predominam as relacionadas aos ambientes de praia (figura 2). 
Figura 2: Material publicitário referente a Armação dos Búzios

The nature invites you and your family to an unforgettable encounter.
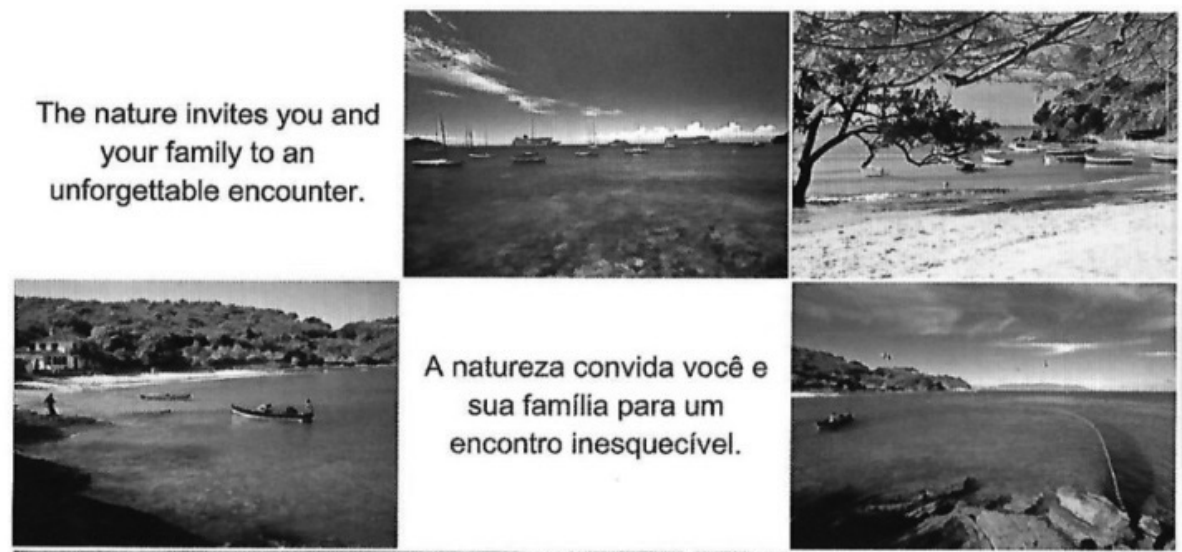

A natureza convida você e sua família para um encontro inesquecivel.
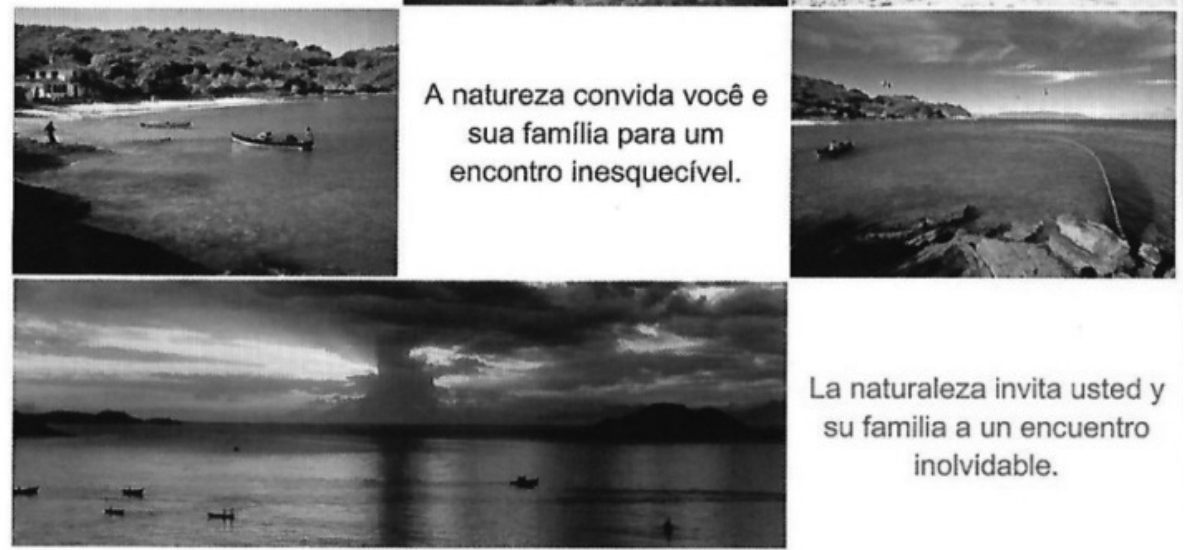

La naturaleza invita usted y su familia a un encuentro inolvidable.

Fonte: Secretaria de Turismo de Armação dos Búzios, s/d.

No caso de Cabo Frio, cabe destacar que, desse município, emanciparam-se diversos outros que compõem a Região de Governo das Baixadas Litorâneas, na qual exerce um papel de centralidade que perdura até os dias atuais. Sobre a região, esta observou, a partir da década de 1970, um incremento econômico e populacional em razão especialmente da melhoria das condições de acesso a partir da Região Metropolitana. Na década de 1990, emergiu ainda o setor petrolífero, com destacada influência na região, visto que quatro de seus municípios (Armação dos Búzios, Cabo Frio, Casimiro de Abreu e Rio das Ostras) estão na denominada Zona de Produção Principal (Nunes, 2015).

Barcellos (2016) afirma que o desenvolvimento econômico de Cabo Frio ocorreu historicamente a partir de recursos oriundos da pesca e da produção salineira, havendo uma modificação desse cenário a partir da fusão entre os estados da Guanabara e do Rio de Janeiro, em 1975, pois foram criados planos de integração para o território fluminense, incluindo eixos rodoviários que articulassem o recém-criado estado do Rio de Janeiro. Com essas novas condições de 
acesso e incentivos econômicos diversos, "o turismo torna-se atividade marcante" (Barcellos, 2016, p. 28).

De acordo com a Secretaria de Turismo, no ano de 2016, o número de turistas que chegaram a Cabo Frio, na chamada alta temporada, ultrapassou 800 mil pessoas, o que representa cerca de quatro vezes o tamanho da população local. O município é ainda importante exemplo para a análise do fenômeno da segunda residência em território fluminense, pois, de acordo com o IBGE (2010), 33\% dos domicílios desse município eram de uso ocasional.

Em relação à capital fluminense, a cidade do Rio de Janeiro, verificamos que, nas últimas décadas, há uma preocupação crescente com a valorização e a criação de elementos a serem vendidos externamente, pautando a atuação do poder público especialmente na reestruturação urbana, que se apoia nos megaeventos esportivos sediados pela cidade. Barre (2013, p. 46) entende que

os megaeventos seriam então o pretexto para repensar, planejar e executar uma transformação profunda da cidade do Rio, a fim de urgentemente fazer dela uma cidade 'de fluxos', 'global', 'cosmopólita', 'inteligente', 'criativa', 'tecnológica', 'festiva', 'sede' (host city), e talvez, sobretudo, afinal, '(ainda mais) atrativa'.

Entre os anos de 2007 e 2016, o Rio de Janeiro sediou três dos principais eventos esportivos mundiais, os Jogos Pan-Americanos, a Copa do Mundo de Futebol e as Olimpíadas de verão, que ocasionaram a criação de variados fixos ligados ao esporte no espaço urbano carioca, como o Estádio Olímpico João Havelange (posteriormente renomeado para Estádio Olímpico Nilton Santos), o Parque Aquático Maria Lenk, a Arena Multiuso, o Complexo esportivo de Deodoro, diversas instalações que compõem o Parque Olímpico, entre outros, além de intervenções sobre a aparência de elementos que fazem parte da paisagem carioca há décadas, como as reformas pelas quais passou o estádio do Maracanã. Cumpre fazer referência que muitos desses empreendimentos estão abandonados e sem utilização, principalmente aqueles localizados na Zona Oeste carioca, mais precisamente, na Barra da Tijuca, bairro que teve instalações importantes para os Jogos Pan-Americanos de 2007 e os Jogos Olímpicos de 2016. 
Associados a outros elementos, como a predisposição do quadro natural, os elementos históricos e a evolução dos transportes, a cidade do Rio de Janeiro constitui-se como um dos principais destinos brasileiros, segundo classificação do Ministério do Turismo (2015), que a inclui na categoria A, juntamente com outros cinquenta municípios brasileiros. Ribeiro (2003), ao desenvolver a tipologia das localidades com atividades turísticas e de apoio, insere a capital fluminense no tipo (função) litorânea e subtipo diversificada, caracterizada por englobar diversas modalidades de turismo. Essas duas categorizações evidenciam, portanto, a variedade da oferta e a importância adquirida pela atividade turística para a economia carioca ao longo do período selecionado.

Fratucci (2005) apresenta tentativas de desenvolvimento do turismo, sendo válido ressaltar algumas das que inserem a cidade do Rio de Janeiro em seu recorte, como o Projeto Turis (1973-75); a identificação do espaço turístico estadual (1979-81), proposta realizada pela Embratur e desenvolvida no estado do Rio de Janeiro pela Flumitur; a Campanha Cidades Maravilhosas do Estado do Rio de Janeiro (1988-90), estabelecida pela TurisRio; o Plano Diretor de desenvolvimento de polos de turismo náutico (1988-90); o Plano Diretor de Turismo do estado do Rio de Janeiro (1997-2001). Mais recentemente, verificamos a proposição de campanhas como "Rio de Janeiro a Janeiro", realizada mediante a parceria entre a prefeitura municipal, o Governo Federal e empresários, tendo como foco o aumento do fluxo de turistas por meio da exposição do potencial turístico da cidade.

As iniciativas apresentadas constituem algumas das propostas estabelecidas pelo poder público para a gestão do turismo, pautando-se muitas vezes em recortes espaciais amplos, mas que incluem a cidade Rio de Janeiro.

A partir do que foi exposto, procuramos evidenciar algumas práticas e localidades privilegiadas pelos fluxos turísticos em território fluminense, cabendo ressaltar, entretanto, que há diversos outros municípios e tipologias de imensa representatividade para a atividade no contexto estadual, mesmo que não classificadas como de nível A pelo Ministério do Turismo.

\section{Arremates}

O território fluminense tem nas atividades de lazer importante fator no que diz respeito a seu desenvolvimento social e econômico, notadamente quando tratamos das atividades relacionadas ao turismo, sendo o referido recorte 
espacial uma das unidades federadas de maior importância para a promoção do Brasil como destino de visitantes nacionais e estrangeiros.

Pudemos constatar a relevância de elementos, como a história dos municípios e as atividades econômicas neles desenvolvidas, a melhor acessibilidade ao interior, especialmente por meio da construção e melhorias de rodovias que ligam a metrópole ao interior, a partir da década de 1970, e o elemento físico/ natural, imensamente valorizado por agentes promotores e consumidores do turismo, quando tratamos do recorte espacial em tela.

Apesar da representatividade da capital estadual, exacerbada após a realização de megaeventos esportivos neste século XXI, também identificamos diversos municípios do interior que conseguiram usufruir de suas possibilidades turísticas, como são os casos de Armação dos Búzios, Cabo Frio, Paraty e Angra dos Reis. Estes, de acordo com o Ministério do Turismo, são aqueles nos quais o turismo apresenta maior grau de desenvolvimento no estado, estando entre os cinquenta no país que se encaixam nas especificações necessárias para compor a categoria A da classificação já indicada.

Mas, mesmo tratando de uma atividade que traz divisas em nível estadual e municipal, os órgãos competentes em diferentes instâncias poderiam elaborar políticas mais eficientes, que permitissem a inclusão de maior parte da população local, oferecesse incentivo educacional e qualificação da mão de obra e promovesse infraestrutura e empreendimentos mais adequados e com melhor localização, não copiando modelos de países e cidades centrais (caso de modelos europeus), que muitas vezes não se adequam às realidades locais, excluindo a população. Tais questões ficam para discussão em outra oportunidade.

\section{Referências}

BARBOSA, Talita Prado e SILVA, Odair Vieira da. "Origens e significados do lazer". Revista Cientifica Eletrônica de Turismo, ano III, n. 14, Rio de Janeiro, 2011.

BARCELLOS, Cláudia Márcia. Mobilidade urbana: efeitos causados pelo turismo de massa no município de Cabo Frio (monografia - graduação). Universidade Federal Fluminense, 2016.

BARRE, Jorge de La. "Choque de futuro: o Rio dos megaeventos". Revista O Social em Questão, ano XVI, n. 29, pp. 43-68, Rio de Janeiro, 2013. 
CIDE - 1997, 2014. “Estado do Rio de Janeiro: território”. Rio de Janeiro: CIDE, 2014.

CORRÊA, Renata da Silva. "Diferentes territórios, territorialidades divergentes: os territórios do turismo em Angra dos Reis (RJ)". In MARAFON, Glaucio José e RIBEIRO, Miguel Angelo (orgs.). Revisitando o Território Fluminense III. Rio de Janeiro: Gramma, 2010, pp. 113-34.

COSTA, Romulo de Oliveira. "A (re)produção do lugar turístico aliado à lógica dos ambientes de atração permanente: o exemplo da expansão do fenômeno do Ecoturismo na Ilha Grande - Angra dos Reis (RJ)". In MARAFON, Glaucio José e RIBEIRO, Miguel Angelo (orgs.). Revisitando o Território Fluminense III. Rio de Janeiro: Gramma, 2010, pp. 77-88.

. "A paisagem como recurso capitalista para o turismo: o exemplo de apropriação da paisagem da Ilha Grande - Angra dos Reis/RJ”. In MARAFON, Glaucio José e RIBEIRO, Miguel Angelo (orgs.). Revisitando o Território Fluminense IV. Rio de Janeiro: Gramma, 2012, pp. 91-110.

FRATUCCI, Aguinaldo César. "A formação e o ordenamento territorial do turismo no estado do Rio de Janeiro". In BARTHOLO, Roberto et al. (orgs.). Turismo e sustentabilidade no Estado do Rio de Janeiro. 1 ed. Rio de Janeiro: Garamond, 2005, v. 1, pp. 81-109.

GOMES, João Carlos (org.). Caderno de turismo do estado do Rio de Janeiro: passaporte para o desenvolvimento do estado. Rio de Janeiro: Fecomércio, 2010.

IBGE - Instituto Brasileiro de Geografia e Estatística. Censo Demográfico, 2010.

MARAFON, Glaucio José et al. Geografia do estado do Rio de Janeiro. Rio de Janeiro: Gramma, 2011.

MENOIA, Thelma Regina Marialva. Lazer: história, conceitos e definições (monografia - graduação). Unicamp, 2000.

MINISTÉRIO DO TURISMO. Categorização dos municípios das Regiōes Turísticas do Mapa do Turismo Brasileiro. Brasília, 2015.

MOTA, Carlos Guilherme e LOPEZ, Adriana. História do Brasil: uma interpretação. São Paulo: Senac, 2016. 
NEGEF. "Caderno de Turismo: apoio à orientação da atividade turística no Estado do Rio de Janeiro”. In MARAFON, Glaucio José e RIBEIRO, Miguel Angelo (orgs.). Revisitando o Território Fluminense III. Rio de Janeiro: Gramma, 2010, pp. 9-24.

NUNES, Nathan da Silva. Transformações nas dinâmicas populacional e econômica a partir dos impactos dos royalties petroliferos no municipio de Casimiro de Abreu-RJ (monografia - graduação). UERJ, 2015.

Imagem e representações nos cartões postais: a paisagem dos municípios de Armação dos Búzios, Casimiro de Abreu e Saquarema, na região das Baixadas Litorâneas (dissertação). UERJ, 2017.

RAHY, Ione Salomão. "Povoamento do estado do Rio de Janeiro". GEOUERJ, Departamento de Geografia, UERJ, n. 6, pp. 37-43, Rio de Janeiro, 1999.

RIBEIRO, Miguel Angelo. Considerações sobre o espaço fluminense: estrutura e transformações (mimeo). Departamento de Geografia/UERJ, 2001.

. "Turismo no estado do Rio de Janeiro: ensaio de uma tipologia". GEOgraphia, ano V, n. 10, 2003, pp. 79-91.

SILVA, Gustavo Junger da. "O turismo histórico como vetor de desenvolvimento sócio-econômico em Paraty: estratégias, limitações e reflexos no urbano”. In MARAFON, Glaucio José e RIBEIRO, Miguel Angelo (orgs.). Revisitando o Território Fluminense II. Rio de Janeiro: Gramma, 2008, pp. 263-86. 


\section{Ser "carioca"/ser "fluminense": la creación de identidades por las fronteras politico-administrativas en el espacio sudamericano}

Augusto César Pinheiro da Silva

\section{Introducción}

La creación de las identidades territoriales dase a través historicidades espaciales asociadas a los movimientos político-administrativos y económicos en tiempos y espacios específicos. Una de las características más destacadas de estas creaciones es la frontera, un mecanismo de límite y definición de proyectos de política territorial, cuyos agentes instituidos históricos para sus delimitaciones deben ser identificados en las investigaciones académicas de las Ciencias sociales y políticas. La ciudad-estado Río de Janeiro, en Brasil, posee una historia "sui generis" en la creación de sus identidades socio espaciales expresadas no solamente en sus distintos territorios, sino en perspectivas antropológicas y sociológicas diferenciadas, con fuerte impacto en el espacio de Brasil.

La construcción del "ser carioca” y del "ser fluminense” en el país implicó en condiciones espaciales muy diferenciadas en sus respectivos territorios, que refuerzan la idea de que hoy, frente a la metropolización en el mundo, las fronteras territoriales son fluidas y necesitan ser revisadas y repensadas para que una nueva condición de pertenencia a los territorios sea creada y fortalecida para la calidad de vida en ambientes demográficamente millonarios de grandes metrópolis del mundo. 
Entre la condición de "ciudad real” de Río de Janeiro en el siglo XVII y su situación geopolítica como sede del Reino de Portugal en el siglo XIX, hacia su separación de la provincia fluminense en 1834 y su condición de distrito federal (1891-1960) y capital de una unidad federativa fusionada (1975) después de casi 150 años sometidas (ciudad y provincia) a gestiones políticas diferenciadas, la frontera ciudad-provincia no impidió que la vida social de esos dos fragmentos territoriales mantuviese casi única también por las cuestiones geográficas. Y son esas cuestiones fundamentales para el la comprensión de Río de Janeiro, hoy en día, y los estudios metropolitanos de Brasil.

\section{La importancia de la Bahía de Guanabara para la fundación de la Ciudad de Río de Janeiro en las rutas comerciales del Atlántico sur}

A principios del siglo XVI, en abril de 1500, las carabelas portuguesas desembarcaban en el continente sudamericano. El Tratado de Tordesillas (1494) encontró, como una línea de demarcación entre las tierras de la Corona de Portugal y el Reino de Castilla, el meridiano a 370 leguas al oeste de la isla de Santo Antão, en el archipiélago de Cabo Verde, África. Esta línea se encuentra a medio camino entre las islas portuguesas y las islas del Caribe, descubiertas por Cristóbal Colón y que pertenecían al Reino de Castilla. Los territorios al este de dicho meridiano serían de Portugal, mientras que los territorios al oeste, de Castilla. El tratado fue ratificado por Castilla el 2 de julio y Portugal el 5 de septiembre de 1494.

Por lo tanto, casi todo el este de la costa del continente sudamericano llegó a pertenecer a Portugal, que inmediatamente envió expediciones al Nuevo Mundo con la intención de encontrar las importantes minas de oro y plata que han impulsado el crecimiento y el fortalecimiento de las emergentes economías de mercado de los imperios europeos. Estos, a su vez, iniciaron una nueva fase de la economía global, basada en el mercantilismo y en la expansión colonial de nuevas tierras conquistadas por el advenimiento de las tecnologías de circulación marítima por los grandes océanos del planeta.

A pesar del fuerte interés de los portugueses por la colonización de la parte noreste de su legado continental en Suramérica (debido a la proximidad de esta región con el continente europeo y el clima cálido y húmedo que reforzaba las actividades de exportación de caña de azúcar a Europa), el gran deseo de ese reino ibérico era el control de parte del circuito mercantil que florecía a través del 
atlántico sur bajo el mando de la Corona española. Reforzar el flujo de metales preciosos procedentes de la bahía del Río de la Plata, bajo el mando español, obligaba Portugal a buscar tierras más hacia sur, más meridionales (imagen 1), para llegarse a lo territorio español por el continente a través de las entradas de colonos mamelucos e indios cristianizados. Comenzaba así la quiebra de la primera frontera occidental en América del Sur (Tordesillas) para la búsqueda de los yacimientos de oro y plata en el interior del continente, dominado oficialmente por el Reino de España, pero poco vigilado debido a la amplitud del espacio territorial. En realidad, el sobrepaso de la primera frontera se dio más intensamente por la vasta red hidrográfica del continente, especialmente las del Río Amazonas y los de la Cuenca del Río Paraná, esa centralizada entre los dos territorios imperiales europeos. Así el Reino de Portugal podría llegar a Potosí, en el corazón de la América española (imagen 1), donde procedía la información sobre grandes depósitos de oro y plata explotados por los colonizadores españoles. Si por el océano la llegada a Potosí sería muy compleja debido a la fuerza de las escuadras españolas, por la navegación fluvial de los ríos que desaguaban en el Atlántico, las entradas de los colonos por tierras continentales en la dirección del deseado dominio español no eran imposibles. 
Imagen 1: Reparto de Sudamérica entre los Reinos de España y Portugal en los siglos XV y XVIII

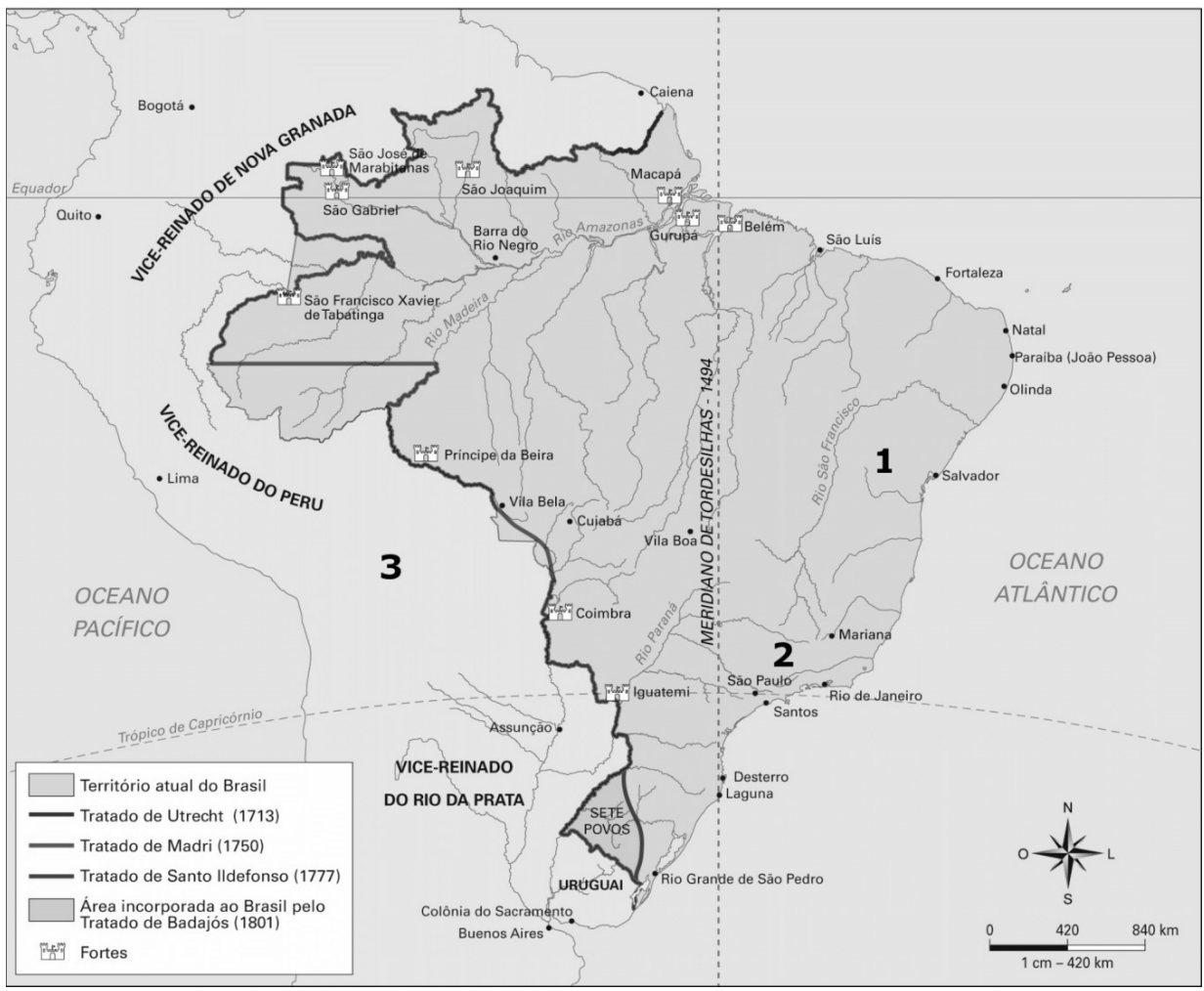

Número 1: Espacio inicial de la colonización económica portuguesa en América del Sur (Noroeste)

Número 2: Presencia portuguesa en el Sur de la colonia a ampliar en control del flujo de metales de España (Sureste)

Número 3: Potosí, el 'sueño dorado y plateado' de los imperios coloniales en Suramérica (actual Bolivia)

Asequible en: https://br.pinterest.com/pin/218002438191493671/?lp=true. Fecha de consulta: 13 enero 2018.

Adaptado.

Las ventajas de Portugal también se ampliaran con la fundación de la ciudad de San Sebastián de Rio de Janeiro en 1565 a la entrada de la Bahía de Guanabara, porque el Reino de Portugal controlaría parte de los flujos mercantiles, no sólo de oro y plata en circulación en el Atlántico sur, sino también de los nuevos comercios de productos alimenticios y esclavos provenientes del continente africano. Dicho control se le dio el puesto comercial importante a la pequeña ciudad tropical de arquitectura portuguesa en el medio del camino entre la Bahía del Río de la Plata y Europa, y la ciudad de Río de Janeiro se 
convirtió en una parada estratégica para los navegantes europeos a lo largo de los siglos XVII y XVIII. Río de Janeiro si ha tornado ciudad puerto ubicada en una bahía bellísima, donde los barcos se abastecían antes de salir rumbo a distancias más largas tanto hacia el sur del continente sudamericano y el norte, hacia Europa y el Caribe.

Imagen 2: La Bahía de Guanabara (1) e la Ciudad de San Sebastián de Río de Janeiro (2)

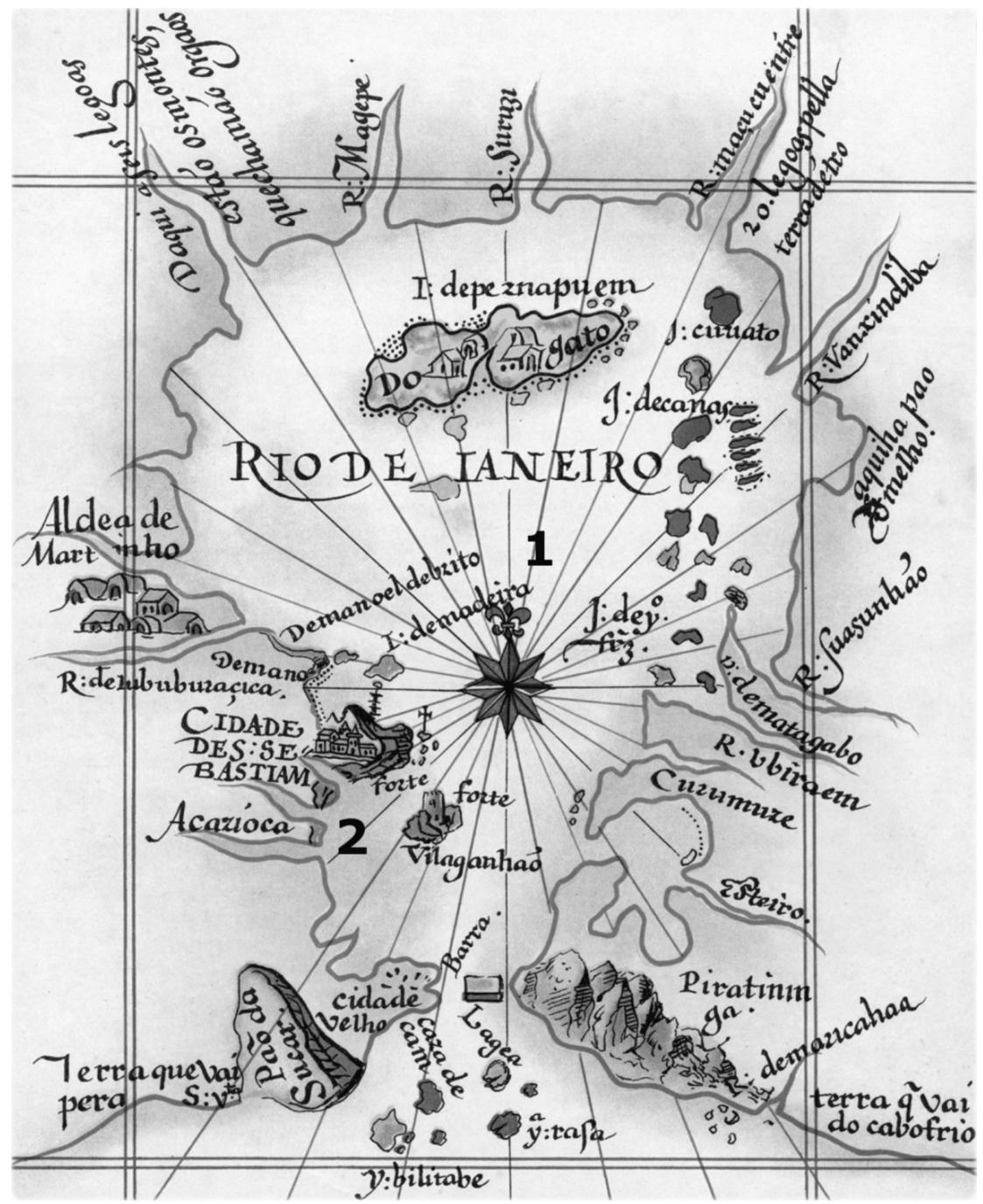

Asequible en: http://www.rio-turismo.com/mapas/luis-teixeira.htm. Fecha de consulta: 13 enero 2018. Adaptado. 
Al ubicarse en el camino a las principales rutas comerciales en el Atlántico Sur, la ciudad de Río de Janeiro fue elevada a capital de la colonia portuguesa en América (1763) tanto por la disminución de las actividades de caña de azúcar en el noreste de Brasil, así como por el descubrimiento de la "brasileña Potosí" en las ciudades de la Provincia de Minas Gerais, en el interior más distante del litoral ampliamente colonizado y explotado. La nueva condición económica transformó los puertos del Sudeste en los más importantes de la colonia ya que los del Nordeste, a partir del siglo XVIII, entraron en plena decadencia. Por lo tanto, la sede de la colonia ubicada en la Bahía de Guanabara llevó para allá la burocracia del Estado portugués al Río de Janeiro y la nueva posición político-administrativa de la ciudad impulsó el crecimiento urbano de la pequeña localidad conocida hacía mucho tiempo como la de casas coloniales en medio de la selva tropical y la muy grandes diversidades biológicas marina y continental, lo que pasó a acuñar su fama de 'paraíso tropical'. La importancia del puerto de la ciudad de Río de Janeiro fue impulsado por el importante Bahía de Guanabara, que, rincón del paraíso de las ballenas y los bancos de peces, se convirtió en una fortaleza importante para barcos de las fuerzas imperiales europeas (sobre todo de la escuadra inglesa) y del propio imperio brasileño, a ser fundado en la segunda década del siglo XIX tras el retorno de la familia hacia Europa en 1822.

\section{Narrativas espaciales sobre "cariocas" y "fluminenses" y sus territorios de desarrollo del imperio brasileño}

La llegada a Río de Janeiro de la familia real portuguesa en 1808 cambió en definitivo la posición política, territorial, social y espacial de la ciudad portuaria en el sureste de la colonia. De acuerdo con Abreu (1992), circa de 15 mil personas de la corte portuguesa y sus colaboradores llegaron a las carabelas a Río de Janeiro, y generaran de inmediato un gran problema de la ocupación alrededor de la Bahía de Guanabara que, en aquél momento, de acuerdo el mismo autor, ya contaba con casi 250 mil habitantes. Los cambios políticos y administrativos rápidos impuestos a la ciudad-puerto de Río de Janeiro entre 1763 (año en que fue nombrada como la sede de la colonia portuguesa en América) y 1808 (fue convertida en la sede del imperio portugués), generaran acciones muy intensas en su modelado urbano. Río de Janeiro tenía un sitio muy tímido y exprimido entre el océano y los macizos costeros, y era restringida 
a los 4 morros históricos sobre los cuales la ciudad se asentó en los casi 250 años de su fundación.

Hay que señalar que la palabra carioca, gentílico para los nacidos en la ciudad de San Sebastián de Río de Janeiro, es utilizada desde el siglo XIX, cuando la primera Constitución imperial del nuevo país (1824) pasó a vigilar, separándose, en 1834, una parte del territorio fluminense para convertirlo en la nueva unidad territorial nombrada "Municipio Neutro" (territorio real para la gestión directa de la Corona brasileña y donde está el sitio histórico de la ciudad de Río de Janeiro). El resto de la provincia de Río de Janeiro, a partir de entonces, fue nombrada "Provincia fluminense". Pero, ¿qué significan esos nombres? En el siglo XVI, los indios Tupinambás, que dominaron la región de la Bahía de Guanabara, han bautizado a los invasores portugueses Akari (término tupí guaraní de una especie de pez, el pez gato), debido al hecho de que los cascos de los soldados portugueses se asemejaban a las escamas típicas que revisten ese pescado. 
Imagen 3: La ciudad de Río de Janeiro en comienzos del siglo XIX: una población de circa 50 mil habitantes entre los cuatro morros históricos: (1) do Castelo (del Castillo), (2) Santo Antônio (San António), (3) São Bento (San Benito) y (4) da Conceição (de la Concepción). La llegada de la Familia Real en 1808 trajo circa de 15 mil personas a vivir en la nueva capital del Imperio portugués

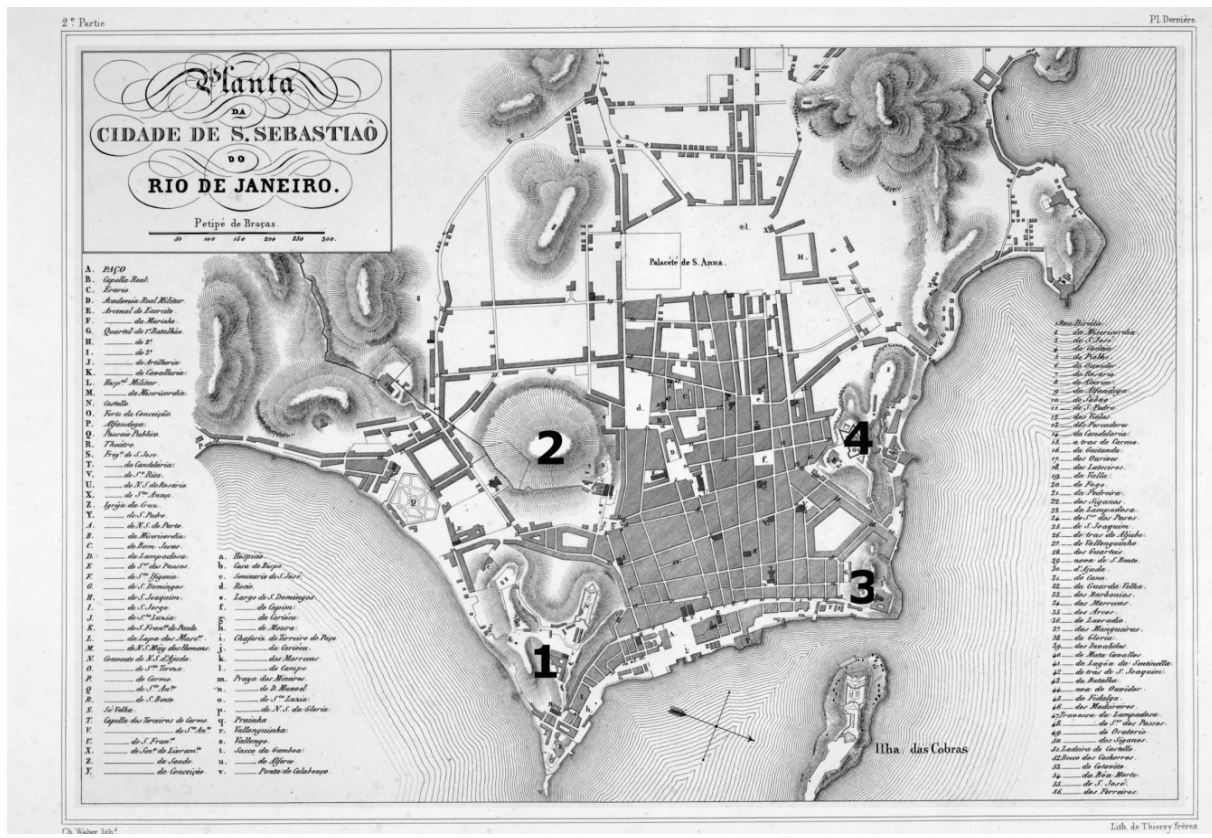

Asequible en: https://br.pinterest.com/pin/272608583669860430/. Fecha de consulta: 13 enero 2018. Adaptado.

Con la segunda expedición portuguesa a la Bahía de Guanabara en 1503, dirigido por Gonzalo Coelho, habría sido construida por los portugueses en una de la desembocadura del Río Carioca, en la actual playa de Flamengo, una casa de piedra que los indios Tamoios llamarían "Akari oka", es decir, "casa del hombre blanco". En la hipótesis alternativa sobre el origen del nombre "carioca", se considera que existía una aldea Tupinambá llamada "Kariok" o "Karióg" al pie de la Colina de la Gloria, en la otra desembocadura del Río Carioca. Con el tiempo, el término "carioca" habría pasado a designar a todos los habitantes de la ciudad. En 1834, a través del Acta Adicional a la Constitución de 1824, el Municipio de Río de Janeiro se separó de la Provincia de Río de Janeiro para constituirse en Municipio Neutro de la Corte, con administración 
vinculada directamente al imperador brasileño. Se definió el gentílico del nuevo municipio: "carioca”. Hasta aquél tiempo, oficialmente, existía sólo el gentílico para la Provincia de Río de Janeiro entera: los “fluminenses”, derivado del latín flumen, fluminis (que significa "río").

Imagen 4: Fondo de la Bahía de Guanabara donde se llegaba hasta medios del siglo XIX solamente por los ríos: la red fluvial intensa en el espacio de los "fluminenses" y sus puertos

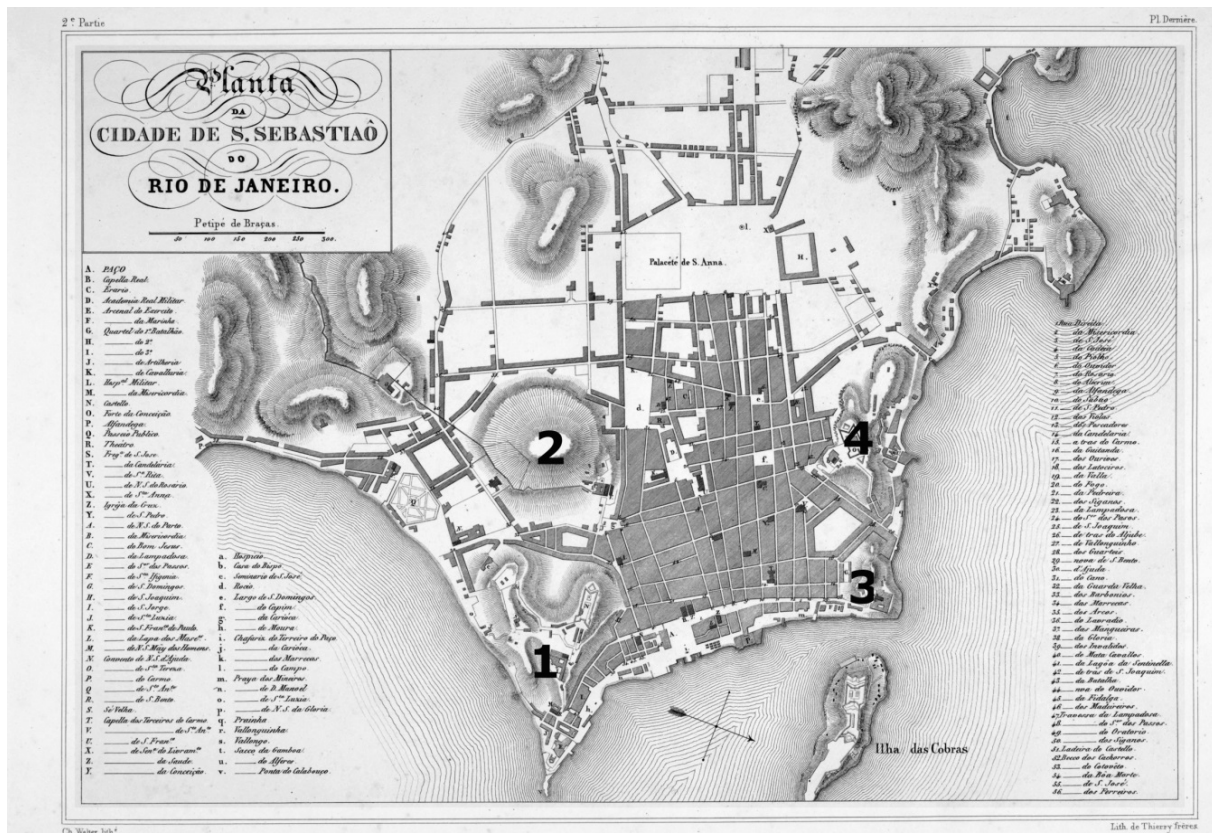

Asequible en: http://verissimohoje.blogspot.com.br/2011/04/ilustrissimos-mageenses-desconhecidos.html. Fecha de consulta: 15 enero 2018 .

Es importante señalar sobre los grandes problemas ambientales que el entorno de la Bahía de Guanabara ya venía sufriendo desde la intensa explotación de los recursos tropicales a las márgenes de los caudalosos ríos que cortaban la "Baixada fluminense". Este espacio, que desde el período colonial estaba ocupado por colonos diversos que explotaban las tierras planas y húmedas de la región para los cultivos de géneros alimenticios de consumo de la ciudad de Río de Janeiro y para la exportación por el puerto de esa ciudad, sufría con el 
sedimentación de sus ríos y el depósito de sedimentos orgánicos e inorgánicos en el fondo y a lo largo de sus lechos, lo que obstaculizaba e reducía la intensa navegación fluvial entre el fondo de la bahía y el interior de la baixada. Muchos puertos fluviales de esa región impulsaban la economía mercantil del período y ayudaban a conectársela al Municipio neutro y sede de la Corona. Tras los constantes y crecientes problemas ambientales, las enfermedades tropicales (dengue, fiebre amarilla, cólera...) se extendían a las haciendas de la baixada que eran afectadas por la muerte de sus trabajadores, especialmente los esclavos, al largo de los siglos XVIII y XIX. La importancia de los ríos para el establecimiento de los contactos sociales y económicos entre la ciudad portuaria e imperial y el interior de la baixada explica el gentílico "fluminense", o sea, aquel que depende de los ríos.

Bajo una condición político-administrativa más amplia que sus capacidades físico-territoriales, la concentración de personas en Río de Janeiro creció exponencialmente a lo largo del siglo XIX. Tal situación generó el desgaste acentuado de los ecosistemas periféricos con la amenaza de que el equilibrio ambiental de la bahía se rompiera debido a la destrucción de los manglares y pantanos típicos de una región tropical con suelos arenosos y capa freática muy cerca de la superficie. Las obras de retroceso del mar fueron dinamizadas para la ampliación del Puerto de Río de Janeiro. Las lagunas en el continente también fueron desecadas. Esas intervenciones urbanísticas e infraestructurales provocaron el inicio de las inundaciones en la ciudad carioca (que son crónicas en los días de hoy) y la capacidad de los ríos de la Baixada fluminense para mantener sus flujos de conexión con la ciudad imperial disminuyó tras la colmatación debido a la deforestación de la mata atlántica. Así, las conexiones entre cariocas y fluminenses pasaron a ser realizadas vía transporte ferroviario (des de la segunda mitad del siglo XIX) y, ya a finales del siglo XIX, a través de los automóviles. El flujo marítimo-fluvial fue cesado y las conexiones entre la ciudad puerto carioca y el interior fluminense tuvieron que ser fortalecidas de otras formas. Todavía la separación territorial ya era sentida social, antropológica y económicamente. 
Imagen 5: Município neutro de Río de Janeiro (1834-1891)

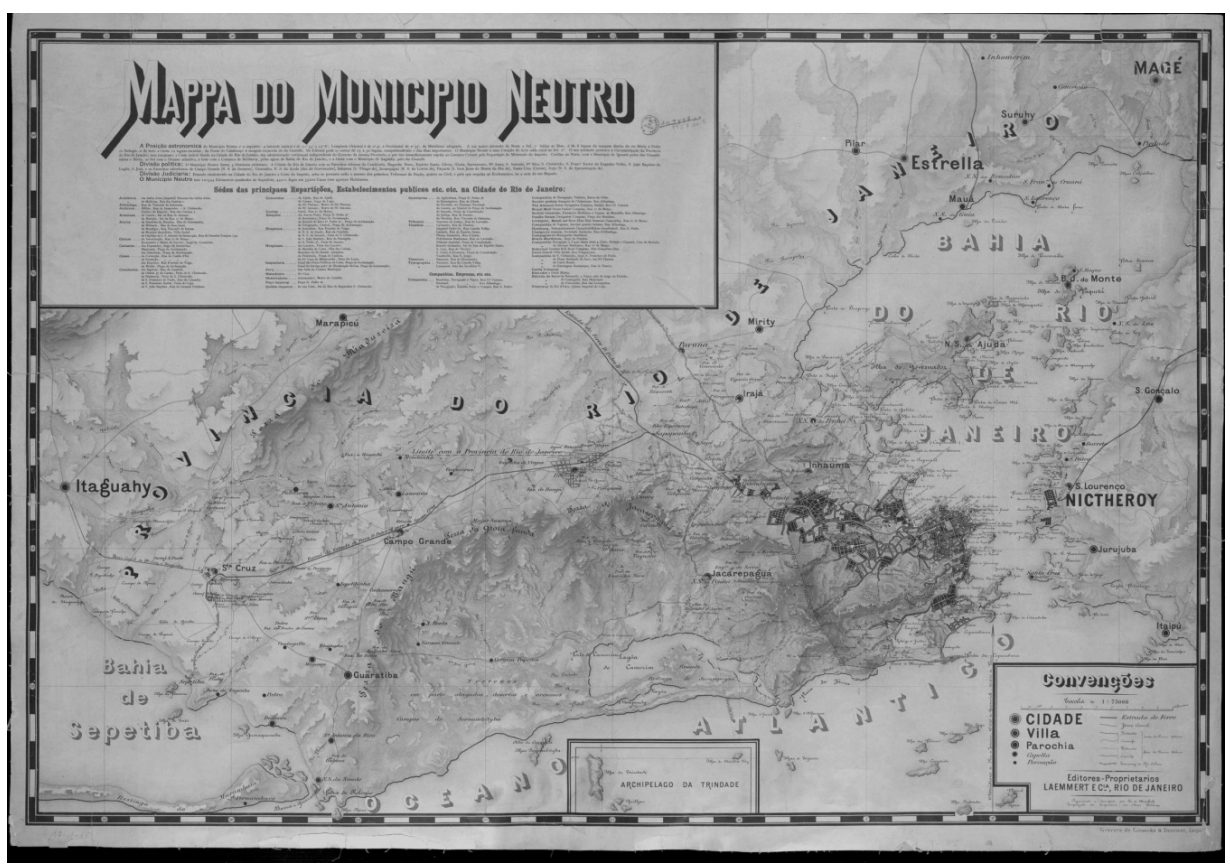

Asequible en: http://www.leilaodeartebrasileira.com.br/peca.asp?ID=50550. Fecha de consulta: 15 enero 2018.

El Brasil Republicano y las fisuras entre la ciudad carioca cosmopolita y el territorio fluminense provinciano: divisiones en las funciones administrativas y económicas y ubicaciones fundamentales para el proyecto de modernidad del país

Durante el siglo XIX, tras la primera constitución del emergente imperio brasileño (1824), el proyecto de modernidad del país se basó en una propuesta imperialista y centralizadora, habiendo tenido la capital del I y II Reinados (la ciudad imperial de Río de Janeiro en el Municipio neutral) un papel fundamental. Siendo sede del imperio y polarizando las fuerzas políticas y económicas del país, se implementó en Río de Janeiro una intensa política "civilizatoria" para que se borrase todos los rasgos del gran período colonial vivido en la región. Las grandes obras infraestructurales y de ampliación de la ciudad fueron realizadas por los poderes del imperio en el municipio neutro, 
lo que impactó las áreas circundantes como las de la Baixada fluminense. Esta, definida como el 'cinturón verde' abastecedor del municipio neutro, mantuvo un perfil agrario-exportador, con una población ocupada en actividades primarias, mientras que en la sede de la Corona la reconstrucción del espacio seguiría las normas, formas y moldes de los imperios europeos asolados por grandes reformas urbanas. Las casas y construcciones coloniales eran derribadas y nuevas calles y edificios suntuosos, además de las últimas infraestructuras urbanas, eran construidos en la ciudad que ganaba un formato más moderno. Ejemplo de ello es que Río de Janeiro fue la primera ciudad de Sudamérica a tener línea telefónica a mando de Don Pedro II, el segundo regente imperial en la segunda mitad del siglo XIX.

Con la llegada de la República en 1889, la primera constitución republicana brasileña (1891) mantuvo la capital en Río de Janeiro y el municipio neutral, a partir de entonces, pasó a tener la condición político-administrativa de "distrito federal". El régimen cambió, pero la lógica espacial y territorial seguía siendo la misma.

Imagen 6: Distrito Federal (Brasil) (1891-1960)

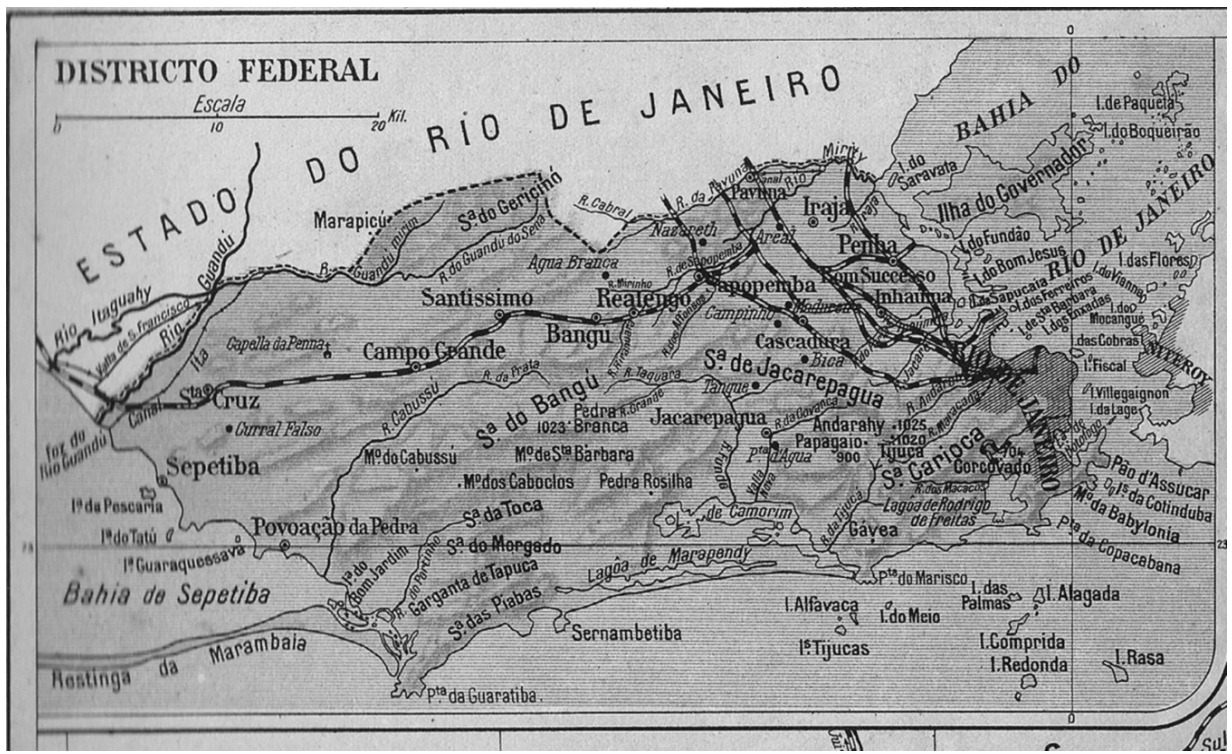

Asequible en: https://pt.wikipedia.org/wiki/Distrito_federal\#/media/File:Distrito_Federal_(Brasil)_-_1922.jpg Digitalizado por Selma Silveira. - Atlas Político do Brasil. Fecha de consulta: 13 enero 2018. 
Con la llegada de la República en 1889, la primera constitución republicana brasileña (1891) mantuvo la capital en Río de Janeiro y el municipio neutral, a partir de entonces, pasó a tener la condición político-administrativa de distrito federal. El régimen político fue cambiado, pero la lógica espacial y territorial de la ciudad y región de Río de Janeiro seguía siendo la misma.

Imagen 7: El derrumbe del Morro del Castillo (primera fase) y el uso de la tierra para crearse suelo urbano: un icono de las intervenciones del alcalde Pereira Passos en las reformas urbanas de Río de Janeiro entre 1902 y 1906

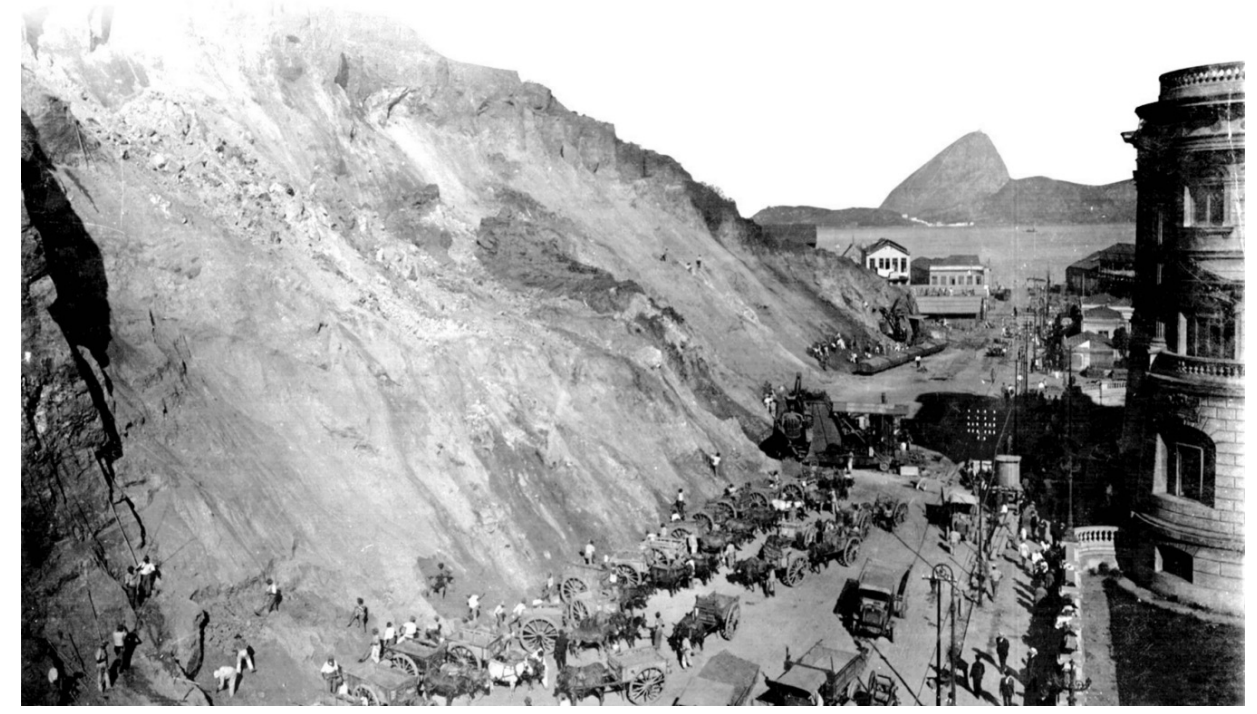

Asequible: Disponible en: https://infograficos.oglobo.globo.com/rio/castelo-360o.html. Fecha de consulta en: 12 enero 2018 .

La república brasileña mantuvo la lógica modernizadora empezada por el imperio en el siglo anterior, y la amplió buscando borrar las marcas imperiales del territorio carioca en el distrito federal. Las grandes obras de modernización de la ciudad a principios del siglo XX - como entre 1902 y 1906 - fueron implementadas por el entonces alcalde de la ciudad, el ingeniero Pereira Passos, ${ }^{1} \mathrm{ex}$

1 En el municipio de Río de Janeiro, el primer gran proyecto de intervención en la configuración espacial y funcional de la ciudad, después de la instauración de la República, en 1889, se dio en la gestión de Francisco Pereira Passos (1836-1913) como prefecto del Distrito Federal 
alumno del francés Barón Haussmann ${ }^{2}$ y su seguidor en relación al modelo de ciudad moderna. Este proyecto de modernización, conocido como "bota abajo" fue el más impresionante que la ciudad de Río de Janeiro tuvo y se convirtió en una fuente de referencias para la modernidad a lo largo del siglo XX en casi todas las ciudades brasileñas. El perfil cosmopolita e higienista de Río de Janeiro fue llevado hasta a las últimas consecuencias y las poblaciones más pobres y que representaban parte expresiva de la historia del país (ex esclavos, migrantes, soldados del período imperial...) fueron gradualmente siendo expulsados de la ciudad carioca dislocándose cada vez más al norte hacia los territorios fluminenses, después de la frontera - vivir en el territorio carioca era mucho más caro que en el territorio fluminense. El "desgarramiento del tejido socioespacial” (Souza, 2000) se reflejó en la modernización conservadora (Graziano da Silva, 1981) que la sociedad carioca/fluminense sufrió. A lo largo del siglo XX, los espacios más pobres de la ciudad histórica de Río de Janeiro fueron derribados y aterrizados, y sus poblaciones más pobres fueron desplazadas por los innumerables gobiernos locales y nacionales que utilizaron la ciudad para sus proyectos de modernidad. Mientras tanto, los espacios fluminenses recibieron parte da las poblaciones más pobres de la ciudad carioca y de otras regiones del país (Marafon e Ribeiro, 2009), así como parte de esas poblaciones venidas del casco histórico y más valorado da ciudad fueran desplazados para las

(1902-1906). Passos era un ingeniero con experiencia y fue nombrado para este cargo por el Presidente de la República Rodrigues Alves (1848-1919), que gobernó Brasil entre 1902 y 1906. Su misión como alcalde fue bien definida: para transformar la ciudad en un civilizado moderno y cosmopolita, digna de ser la capital de la joven república brasileña y atraer para acá visitantes, mano de obra inmigrante y negocios (Cabral, 2017).

2 Georges-Eugène Haussmann fue un abogado, funcionario público, político y administrador francés. Nominado alcalde de París por Napoleón III, tenía el título de Barón y remodeló París por 17 años, con la colaboración de arquitectos e ingenieros de renombre en la época. Haussmann planeó una nueva ciudad, modificando parques parisinos y creando otros, construyendo varios edificios públicos, como L’Opéra. También mejoró el sistema de distribución de agua y creó la gran red de alcantarillas, cuando en 1861 empezó la instalación de las alcantarillas entre La Villette y Les Halles, supervisada por el ingeniero Belgrand. (Fuente: http://estoriasdahistoria12.blogspot.com.br/2013/10/as-transformacoesna-vida-urbana-o.html. Aceso en: 15 enero 2018) 
zonas más distantes de la ciudad, en la frontera del espacio carioca con el fluminense.

En ese sentido es que, aun impulsando un proyecto industrialista en la Baixada fluminense a partir de los gobiernos populistas de los años de 1930, centralizados en el distrito federal, mantuvieron la dinámica segregacionista en las relaciones entre la ciudad y estado (desde 1891 la provincia fue transformada en unidad federada) de Río de Janeiro, ya que los espacios agrarios de la Baixada concentraban a los más pobres migrantes cariocas y de otras regiones del país, no generando una clase media resultante de las inversiones estatales en la industria de la época.

Imagen 8: Ciudades pobres y chabolas ocupan hoy muchos lechos de los ríos de la Baixada fluminense: resultado de las reformas urbanas en el territorio carioca "cosmopolita"

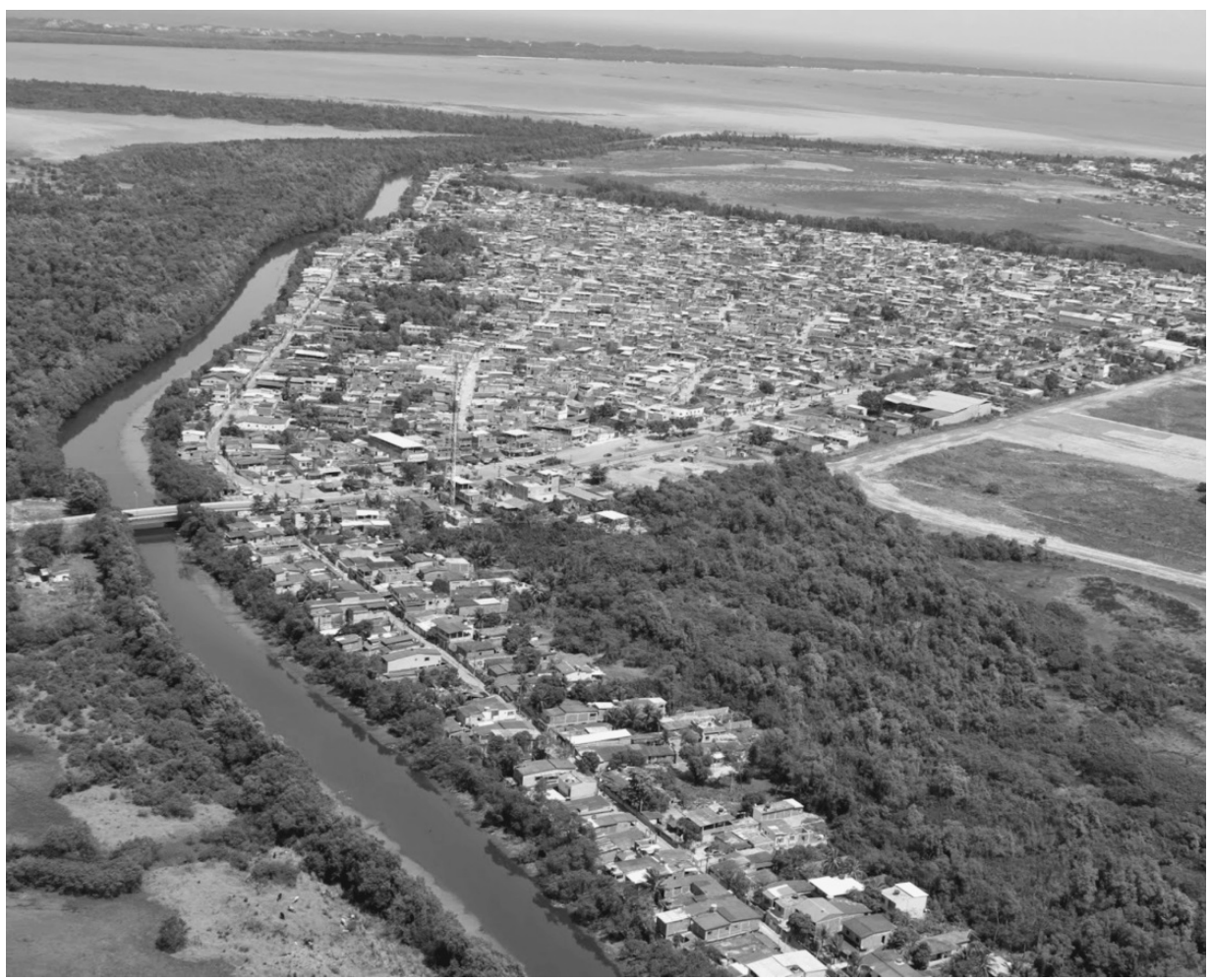

Asequible: http://www.biologo.com.br/MOSCATELLI/marco2009/fotos_marco_2009d.html. Fecha de consulta: 15 de enero de 2018. 
Entre las políticas de modernización de la ciudad de Río de Janeiro y la intensificación de los grandes proyectos industriales en los municipios de la Baixada fluminense, la mancha de población sin educación de calidad y que vive bajo gran pobreza infraestructural y económica se ha ampliado bastante, afectando el mantenimiento del equilibrio en las relaciones sociales y ambientales entre estos dos fragmentos territoriales. Entre los años de 1940 y 1990, las tensiones se amplían mucho con la concentración de millones de pobres entre las fronteras de los territorios carioca y fluminense, lo que afecta la calidad de vida de millones de personas en la región metropolitana de la ciudad de Río de Janeiro.

Mientras la mentalidad hoy en todo mundo sobre la ciudad de Río de Janeiro sea que es un espacio cosmopolita, el espacio periférico cercano a ella - los territorios fluminenses - mantiene su perfil rígido y provinciano. Mientras la ciudad de Río de Janeiro se "civilizaba" a lo largo del siglo XX "a los moldes y encanto de Paris" (a pesar de mantener muchos índices de pobreza bastante graves en los días de hoy), el espacio fluminense se quedaba bajo un perfil colonial, políticamente arcaico y con larga concentración de población cuyas condiciones sociales y ambientales son como a las de las personas en los países de bajo desarrollo en el mundo. 
Imagen 9: El agua contaminada de la Bahía de Guanabara es el resultado de los siglos de separación entre políticas de aguas para la metrópoli y para las ciudades fluminenses que viven bajo la pobreza en sus ríos. El resultante de la pobreza y baja infraestructura se ve en la bahía hoy en día

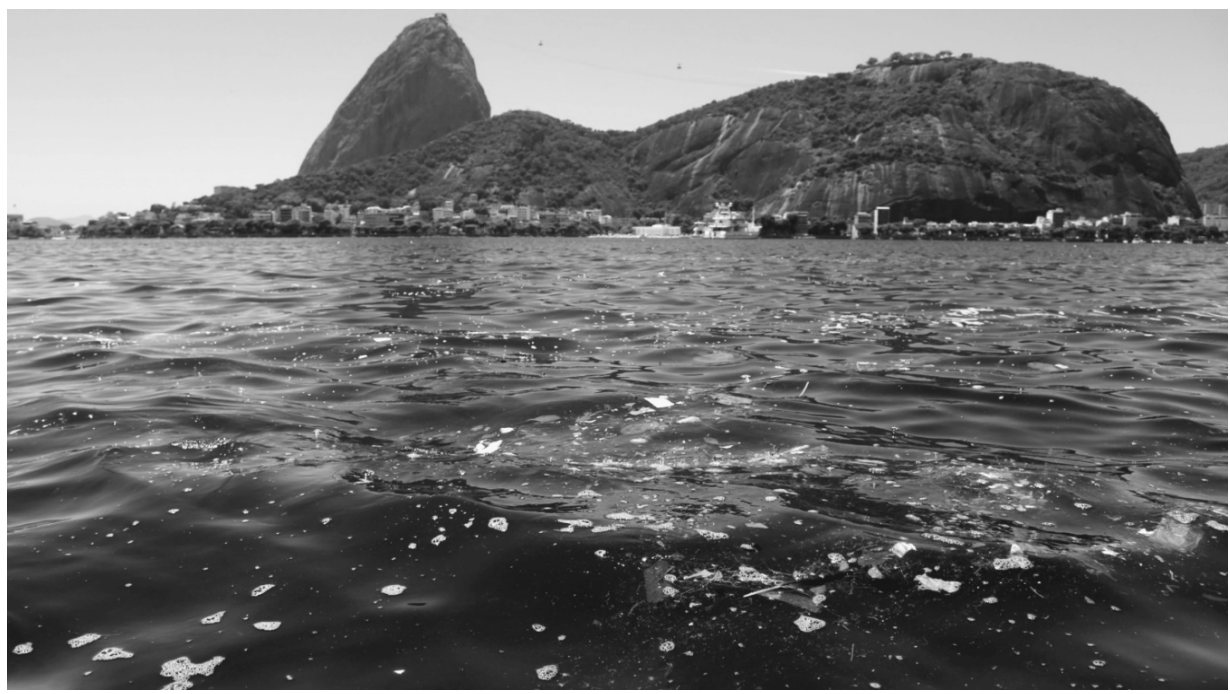

Asequible en: https://extra.globo.com/esporte/rio-2016/jornal-americano-critica-agua-da-baia-de-guanabara-atletas-vao-nadar-na-merda-19791467.html. Fecha de consulta: 15 enero 2018.

La ciudad carioca que ocupa hoy, como metrópoli, toda el área del antiguo Distrito federal (condición que la ciudad de Río de Janeiro perdió en 1960, con la construcción de Brasilia, desde entonces el nuevo distrito federal del país) en extensión, tiene cerca de 6,5 millones de habitantes y forma con otros 20 municipios, una gran región metropolitana con aproximadamente 12,5 millones de habitantes (IBGE, 2017). La “megarregión” Río de Janeiro, frente a los problemas cotidianos de 12,5 millones de habitantes, necesita nuevas soluciones conjuntas y no más seccionadas por las divisiones políticas locales. La gestión de aguas públicas, recogida y deposición de basura, seguridad pública, integración de las redes de alcantarillado y saneamiento básico, movilidad intermetropolitana... son temas cotidianos a todos los habitantes de la región y no sólo en uno de los municipios. Por lo tanto, ¿por qué actuar en la gestión pública de forma cooperativa? 
La historia de separación entre los dos fragmentos territoriales hace 184 años y, actualmente, este se muestra un problema para la gestión territorial del Estado federativo brasileño, porque la mancha macro metropolitana fúndese en una única realidad socioespacial frente a la fuerza del proceso de metropolización (Silva, 2015, 2016), y nuevas formas de aproximación necesitan ser pensadas bajo la óptica de la gestión compartida y cooperativa entre los entes federativos del país.

\section{Servicios ambientales urbanos, las conexiones intermodales entre el terri- torio carioca y la Baixada fluminense y la calidad de vida en Río de Janeiro: dilemas geográficos del siglo XXI}

Imagen 10: Cualidad de vida y salud en la región metropolitana de Río de Janeiro hoy. Las vidas de millones de personas son afectadas por las mala condiciones infraestructurales aun hoy dominantes en los espacios fluminenses cercanos a la ciudad de los cariocas, el Río de Janeiro. Los colores verde (cualidad de vida "muy buena" y "buena") son dominantes en el territorio carioca mientras los colores rojo y amarillo ("mala" y "media" cualidad de vida) son dominantes en el territorio metropolitano fluminense

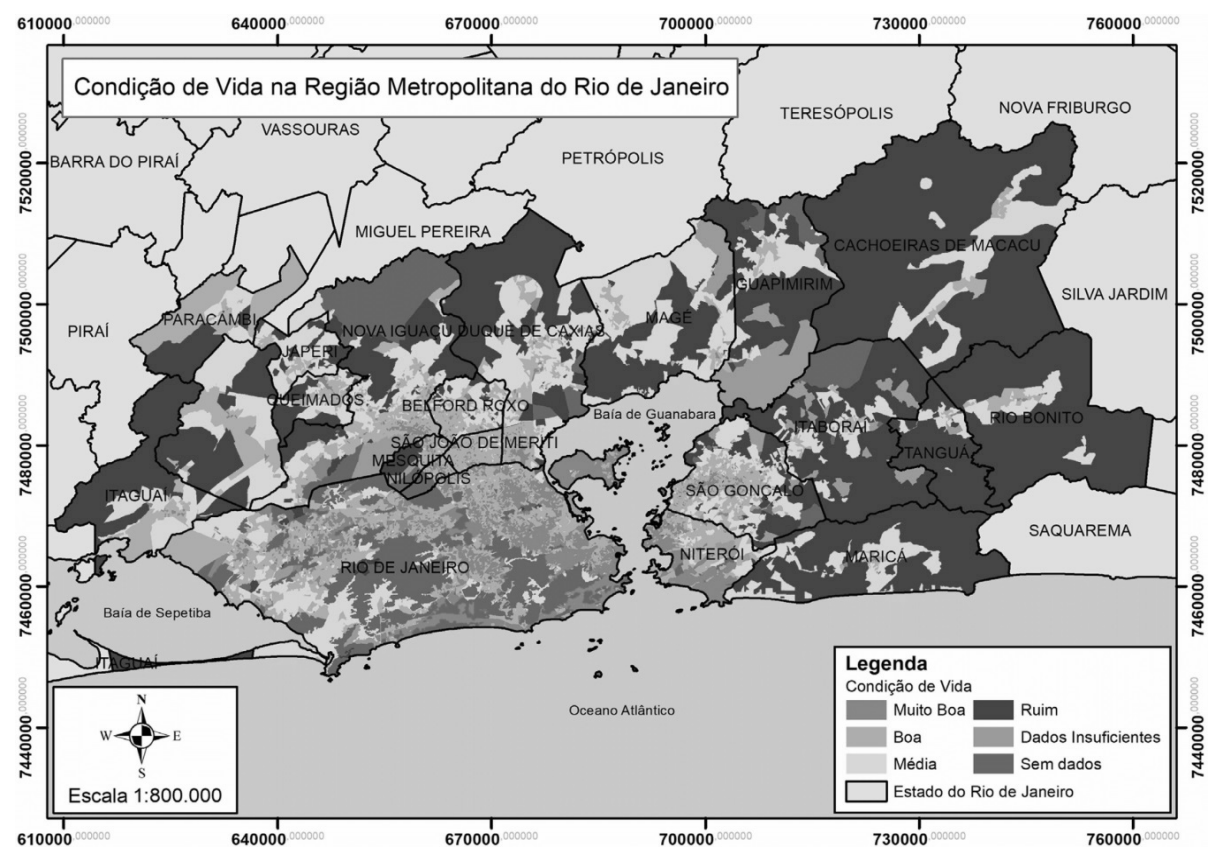

Fuente: Farias, 2017. 
Las fronteras político-administrativas en ambientes conurbados a menudo obstaculizan más que ayudan en las gestiones político-territoriales de los poderes instituidos. Desde el año 1975, cuando la ciudad de Río de Janeiro se convirtió en la capital de la nueva unidad federada del mismo nombre, Río de Janeiro, ciudad y estado (en Brasil, son tres niveles de gestión territorial en el federalismo: Unión, Estados y estados Municipios) intentan definir estrategias de acción para resolver problemas de orden cotidiano que afectan la vida de millones de personas, diariamente.

Imagen 11: Las regiones hidrográficas del estado de Río de Janeiro se subdividen en nueve (09) grandes cuencas hídricas. A la más poblada es de la Guanabara, y es en ella que la contaminación de las aguas fluviales que desaguan en la bahía se concentra. Eso es uno de los hechos más preocupantes para la definición de la baja calidad de vida ambiental en Río de Janeiro. Es a través de esas regiones hidrográficas que las políticas públicas sobre el uso y conservación de los recursos hídricos se realizan en Brasil, en la actualidad

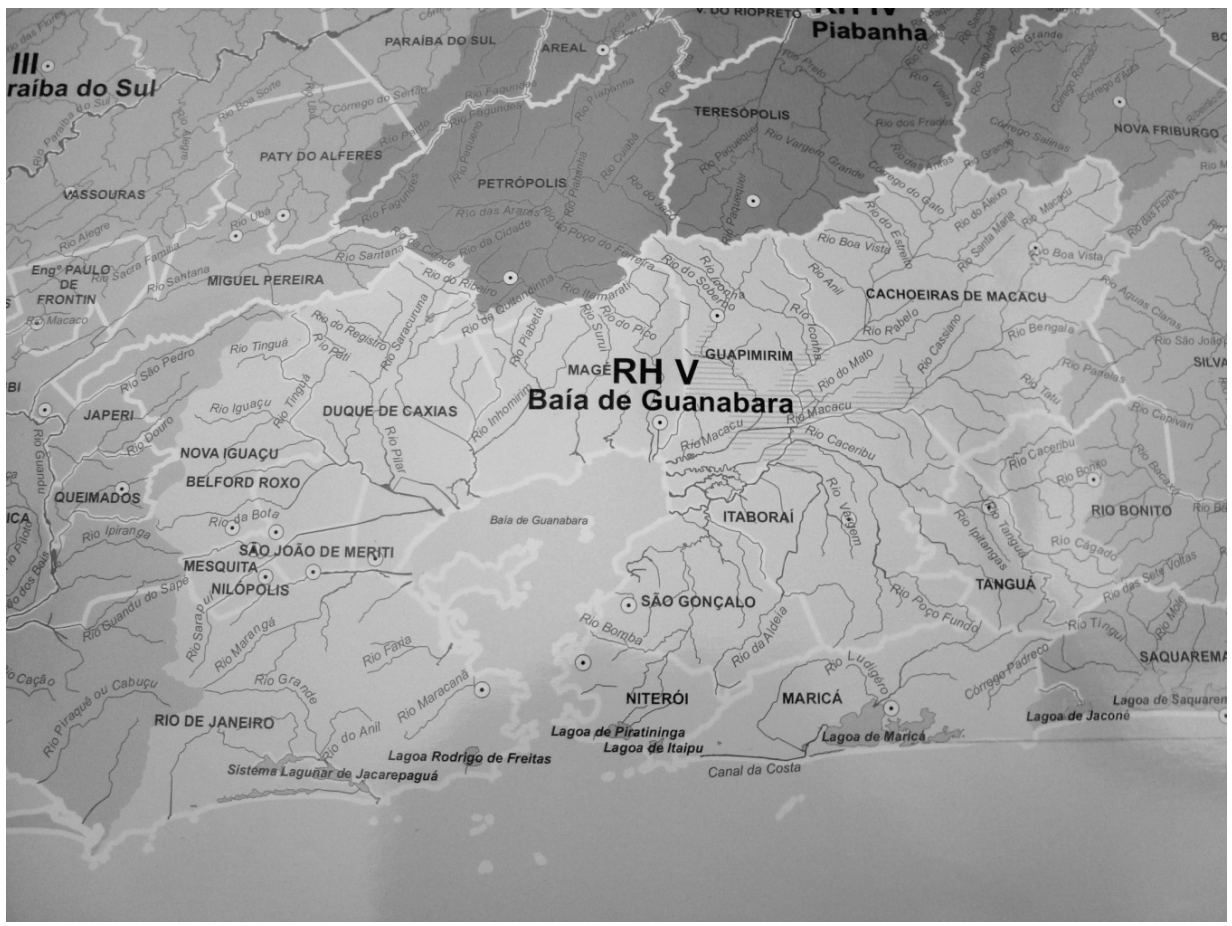

Fuente: Acselrad et al., 2015. 
Es innecesario entrar en las discusiones sobre otras estructuras de representación político-territorial en Brasil para la gestión de los territorios (como las regiones metropolitanas definidas en el año 1975 donde súmanse espacialmente hoy gran parte de la población del país) para la comprobación de que la falta de cohesión territorial entre esas regiones hechas de unidades básicas (los tres niveles, que compiten, muchas veces entre sí al ofrecer servicios básicos y públicos) perjudica las estrategias más actuales de gestión - como a las de nivel cooperativo que promueven sinergias con otros agentes de poder y representación espacial como los movimientos sociales, las agencias privadas, las empresas, las representaciones estudiantiles ... - que todavía son muy efímeras en la sociedad brasileña por la falta de la cultura de participación política popular. Sin embargo, las representaciones oficiales, muchas veces, no ven el espacio de gestión pública con la competencia y la determinación con las que ellas deberían estar incorporadas en la sociedad. Por lo tanto, las complejas formas de gestión son limitadas, muchas veces, en los límites municipales, o en otras unidades territoriales como el propio estado (son 27 estados en la federación), reduciendo el suceso que las resoluciones en las escalas del 'facto espacial' (ejemplo: la gestión de aguas de las cuencas hidrográficas) sean eficientes e productivas, especialmente en ambientes metropolitanos superpoblados y con grandes densidades demográficas (Imagen 11).

En ese sentido, la ciudad de Río de Janeiro, conurbada en su región metropolitana ( $y$, especialmente en su periferia inmediata, la Baixada fluminense), encuentra muchas dificultades para lidiar con la calidad de vida que el rico sistema ecológico de la Bahía de Guanabara ofrece. Tal condición es el resultado de los siglos de mal uso y ocupación irregular de sus márgenes, de la destrucción de sus ecosistemas marinos y continentales tropicales, y deterioro de los manantiales de aguas que fluyen en su extensa cuenca hidrográfica. Otra condición que refuerza el ámbito de los problemas de articulación política entre la ciudad y su región inmediata fue la separación político-territorial de sus funciones político-administrativas en los últimos 184 años. Como se sintetizó en este artículo, la disociación de las perspectivas carioca y fluminense a lo largo de la re-funcionalización de esa región del litoral brasileño por los poderes públicos de diferentes perspectivas y objetivos, redujo hoy la capacidad de los gobiernos de la ciudad carioca, de las ciudades metropolitanas ubicadas en el entorno inmediato de la metrópoli y del estado pensar en soluciones conjuntas y horizontales para tornar la rica naturaleza brasileña una fuente de servicios 
ambientales capaces de amenizar problemas diversos que afectan el día a día de poblaciones millonarias.

En ese sentido, la ciudad de Río de Janeiro, para mantener la condición de ser “maravillosa” (como es conocida internacionalmente), tendrá que reformular las maneras como lidia con las regiones fluminenses de manera más ecuánime y articulada para que la pobreza aún diseminada a los márgenes de la región de la Baixada fluminense sea eliminada y las aguas de la Bahía de Guanabara vuelvan a ser la fuente de riquezas naturales que los brasileños y el mundo aprendieron a respetar. Romper el ciclo de reproducción de las condiciones desiguales entre la ciudad carioca y su entorno fluminense es posibilitar que los recursos naturales y los servicios metropolitanos sean ecualizados por todo el territorio donde habitan millones de personas en la mancha macro metropolitana. Y, para ello, esta investigación en marcha se propone a estimular los lazos entre cariocas y fluminenses a través de nuevas formas políticas para que se refuercen los lazos de pertenencia más allá de las fronteras político-administrativas que la historia de formación de esa parte de la identidad brasileña reforzó hace, por lo menos dos siglos. Ah sí la dinámica espacial puede reducir el daño de una historia de violencia que caracteriza la definición de "ser carioca" y "ser fluminense" con la que la segregación socio-espacial comenzó en el proceso colonial y todavía aún es presente como la marca de la civilización portuguesa en América Latina de hoy.

\section{Referencias}

ABREU, Mauricio de Almeida. A evolução urbana do Rio de Janeiro. Rio de Janeiro: Editora IPP/Pereira Passos, 1992.

ACSELRAD, Moema Versiani et al. "Cobrança pelo uso da água no Estado do Rio de Janeiro, Brasil (2004-2013): histórico e desafios atuais”. Revista de Engenharia Sanitária Ambiental, v. 20, n. 2, pp. 199-208, 2015.

BLOG VERÍSSIMO HOJE. Asequible en: http://verissimohoje.blogspot.com. br/2011/04/ ilustrissimos-mageenses-desconhecidos.html. Fecha de consulta: 15 de enero de 2018.

FARIAS, Heitor Soares. "Espaços de risco à saúde em consequência da poluição atmosférica”. Mercator, n. 16, pp. 1-14, 2017. 
GRAZIANO DA SILVA, José. A crise agrária. Rio de Janeiro: Paz e Terra, 1981.

IBGE Cidades. Instituto Brasileiro de Geografia e Estatística. Asequible en: https:// cidades.ibge.gov.br/. Fecha de consulta: 13 ene. 2018.

JORNAL EXTRA. Jornal americano critica água da Baía de Guanabara. Asequible en: https://extra.globo.com/esporte/rio-2016/jornal-americano-critica-agua-da-baia-de-guanabara-atletas-vao-nadar-na-merda-19791467.html. Fecha de consulta: 15 ene. 2018 .

JORNAL O GLOBO. Infográficos do O Globo. Asequible en: https://infograficos. oglobo.globo.com/rio/castelo-360o.html. Fecha de consulta: 12 ene. 2018.

LEILÃO DE ARTE BRASILEIRA. Asequible en: http://www.leilaodeartebrasileira. com.br/peca.asp?ID=50550. Fecha de consulta: 15 ene. 2018.

MARAFON, Glaucio José. "El espacio rural fluminense: permanencias y mudanzas en el campo”. Mapping Revista Internacional de Ciencias de la Tierra, v. 3, pp. 21-7, 2011.

e QUEIROZ, H. A. "Os caminhos do lixo na cidade do Rio de Janeiro". Cadernos do Desenvolvimento Fluminense, v. 8, pp. 37-54, 2015.

e RIBEIRO, Miguel Ângelo (orgs.). A metrópole e o interiorfluminenses: simetrias e assimetrias geográficas. 1 ed. Rio de Janeiro: Gramma/Faperj, v. 1, 2009.

MOSCATELLI, Mario. “Boca do Mangue”. 2009. Asequible en: http://www.biologo. com.br/MOSCATELLI/marco2009/fotos_marco_2009d.html. Fecha de consulta: 15 ene. 2018.

PINTEREST. Asequible en: https://br.pinterest.com/.Fecha de consulta: 13 ene. 2018.

RIO TURISMO. Asequible en: http://www.rio-turismo.com/mapas/luis-teixeira.htm. Fecha de consulta: 13 ene. 2018.

SILVA, Augusto César Pinheiro. "Redefinindo a paisagem do Rio de Janeiro: dilemas constantes sobre o espaço carioca”. Cadernos do Desenvolvimento Fluminense, v. 5 , pp. 57-73, Rio de Janeiro, 2015. 
. "Gestão Territorial em Regiões Metropolitanas: agendas necessárias para uma governança cooperativa e coparticipativa - o exemplo do Rio de Janeiro". In: (org.). Geografia Política, Geopolítica e Gestão do Território: racionalidades epráticas em múltiplas escalas. Rio de Janeiro: Gramma, 2016, v. 1, pp. 139-168.

. "Uma trajetória de investigação de geografia política na Região Metropolitana do Rio de Janeiro”. GEOgraphia, UFF, v. 18, pp. 95-114, Niterói, 2016.

SOUZA, Marcelo Lopes. O desafio metropolitano. Rio de Janeiro: Bertrand, 2000.

WIKIPEDIA. “Mapa do Distrito Federal”. Asequible en: https://pt.wikipedia.org/ wiki/Distrito_federal. Fecha de consulta: 13 ene. 2018. 
Parte II - Estudos Territoriais na Costa Rica 


\section{Políticas públicas habitacionales: la vivienda social en Costa Rica}

Lilliam Quirós Arias

\section{Introducción}

En Costa Rica, el crecimiento urbano principal se ubica en el Gran Área Metropolitana (GAM). Con una alta concentración de la población, el $60 \%$ población de Costa Rica reside en el área central del país -GAM-; ocupando un $3.5 \%$ del territorio nacional. Un crecimiento caracterizado por ocupar los espacios agrícolas más productivos, un crecimiento urbano desordenado, horizontal y con una alta segregación espacial.

La ocupación del territorio urbanizado, no ha logrado incorporar el tema de ordenamiento territorial, variable esencial para lograr un adecuado desarrollo urbano-rural. La carencia de una planificación del nivel regional y el entrabamiento en la aprobación de planes reguladores, se convierten en procesos arduos, de una extensa tramitología y de resultados poco satisfactorios para la adecuada distribución y asignación en los usos del suelo tanto urbano como rurales; de manera que se garantice una mejor calidad de vida a las poblaciones locales. Asimismo las empresas desarrolladoras bajo un modelo de expansión económica, desarrolla proyectos de vivienda en áreas que carecen de las condiciones para el desarrollo urbano y en áreas fuera del anillo de contención urbano; la falta de control y regulación por parte del estado han agudizado el modelo de expansión horizontal.

De acuerdo a Salinas y Pardo (2017), indican que:

A mediados de la década de 1990 se inicia la retirada del Estado del sector de vivienda y la promoción privada asume la responsabilidad del proceso de 
producción. El papel del Estado se limita a fomentar la oferta y, de manera puntual, apoyar la demanda. El Estado, a través de instituciones públicas, otorga créditos para la adquisición de vivienda de interés social, con lo cual, se genera un mercado potencial y, con ello, se estimula la oferta de vivienda. A este sistema se le conoce como el modelo chileno de producción de vivienda (p. 118).

Este modelo chileno según estos autores se caracteriza por la mala calidad de las viviendas, localización lejana y segregación residencial. Esto provoca que los proyectos de vivienda social sean localizados en la periferia de las ciudades, incidiendo en la expansión urbana. Para el caso de Costa Rica, el anillo de contención urbana establecido en el 1984, en el proyecto Plan GAM, fue sobrepasado por un crecimiento urbano espontaneo y desordenado. Los cantones periféricos mostraron un nivel de crecimiento población mayor.

La Política Nacional de Ordenamiento Territorial aprobada recientemente, cuya rectoría recae en el Ministerio de Vivienda y Asentamientos Humanos (MIVAH), es un instrumento valioso para avanzar en este proceso. Los gobiernos locales, representados por las municipalidades tienen un rol central en el ordenamiento territorial, sin embargo; muchas de ellas carecen de las capacidades técnico - financieras para cumplir con este cometido. La falta de identificación de espacios propios para los proyectos de vivienda social, ocasiona que en muchos casos estos se ubiquen en áreas de alto riesgo, de difícil acceso y sin servicios básicos esenciales; con las posteriores consecuencias para los beneficiarios de las viviendas.

El crecimiento urbano ha significado el abandono de áreas centrales, la ocupación y expansión urbana sobre todo residencial hacia los cantones periféricos, con un crecimiento horizontal del territorio urbanizable. Con la consecuente pérdida de recursos naturales, los problemas de tráfico urbano y los largos desplazamientos para la realización de actividades como trabajo, ocio y educación.

FUPROVI (2015), señala que entre los cantones en declive en cuanto a crecimiento demográfico y residencial; están San José, Tibás, Goicoechea, Montes de Oca. Los cantones, presentaron una disminución de su población en el último período intercensal 2000-11; los cantones periféricos con un ligero aumento: Escazú, Desamparados, Alajuelita, Vázquez de Coronado, Curridabat y Belén, muestran un aumento poco significativo en su población. Los 
cantones atractivos como Aserrí, Mora, Moravia, Alajuela, La Unión, Heredia, Barva, Santo Domingo y San Rafael, para la construcción de vivienda, aunque solo tienen una pequeña parte de su territorio en el anillo de contención urbano. El cantón de mayor atracción: Santa Ana que experimentó un fuerte crecimiento poblacional y residencial. Además concluye que los cantones céntricos y los distritos centrales son los que más registraron decrecimiento de su población y el crecimiento se dio en los cantones y distritos periféricos del Gran Área Metropolitana (GAM), dentro y fuera del anillo de contención urbana.

En el Informe final Hábitat III, el MIVAH - Gobierno de la República de Costa Rica (2016), señala que "el acceso a vivienda está enfocado principalmente en proyectos de vivienda individual en modalidad horizontal. Falta incentivar más la construcción en altura para zonas urbanas donde se debe densificar y el valor de la tierra es elevado" (p. 50). Se propone por tanto, los proyectos habitacionales en altura para las zonas urbanas; y así evitar la expansión horizontal en el desarrollo residencial.

La vivienda de bien social, desde su creación ha significado una opción para muchas familias de escasos ingresos económicos que no logran satisfacer la necesidad básica de vivienda. Con el establecimiento en el año 1986 del Banco Hipotecario de la Vivienda (BANVHI), instancia que canaliza los recursos y solicitudes para dotar de vivienda a esta población; sistema que ha venido adaptándose a las demandas actuales se fortalece el rol del estado en esta materia. Nueva legislación ofrece posibilidades de acceso a la vivienda como la mujer en pobreza extrema, el adulto mayor, la población joven y población en condición de discapacidad. Pese a estos esfuerzos, la población en extrema pobreza sigue con déficit de vivienda así como la población de clase media; esta última con expectativa de vivienda que no son satisfechas por sus ingresos y la oferta en el mercado.

El agotamiento de los terrenos agrícolas se hace evidente en el principal centro urbano metropolitano; el café como principal recurso agroproductivo del GAM, ha sido desplazado por el uso residencial, comercial y de servicios. La actividad cafetalera que caracterizó el paisaje agrario desde 1840, fue reduciéndose y cambiando hacia usos alternativos; los pocos espacios agrícolas cultivados ganan con el tiempo una alta plusvalía; que sin duda serán incorporados al crecimiento urbano. Se hace necesario implementar políticas claras que propicien un crecimiento vertical y que promuevan el acceso de vivienda a los estratos de extrema pobreza y clase media. 


\section{Surgimiento de instituciones públicas para atender las necesidades de vi- vienda}

A mediados siglo las necesidades de vivienda fueron resueltas a través del sector privado o de la autoridad local municipal. Según FUPROVI (2013), desde los años cuarenta se crean las primeras instituciones estatales del sector vivienda y asentamientos humanos; Junta de la Habitación (Ley n. ${ }^{\circ} 37$, de 1940), Cooperativa de Casas Baratas de la Familia (Ley n. ${ }^{\circ}$ 192, de 1942). Fusión de la Caja Costarricense del Seguro Social (CCSS) y la Junta Nacional de Habitación (Ley n. ${ }^{\circ}$ 148, de 1945), el Instituto Nacional de Vivienda y Urbanismo (INVU) (Ley n. ${ }^{\circ}$ 1.788, de 1954) este último nace con el propósito de asegurar la participación del Estado en la solución del problema de vivienda, para las familias de escasos recursos. La Constitución Política de la República del año 1949 establece el rol del estado en la materia, expreso en el Artículo 65: "El Estado promoverá la construcción de viviendas populares y creará el patrimonio familiar del trabajador" (p. 9).

En 1969, se creó el Departamento Central de Ahorro y Préstamo (DECAP), dentro del Banco Crédito Agrícola de Cartago, con el objetivo definido de canalización de recursos financieros y humanos para hacerle frente al problema de vivienda; el cual posteriormente sirvió de base para la formación de las Mutuales de Ahorro y Préstamo.

En los años 70, otras instituciones ponen en marcha iniciativas en el campo de la vivienda de interés social: el Instituto de Desarrollo Agrario (IDA) -hoy Instituto de Desarrollo Rural (INDER)-, el Instituto Nacional de Seguros (INS), el Instituto Mixto de Ayuda Social (IMAS), el Sistema Bancario Nacional y Mutuales. En 1976, el Centro de Naciones Unidas para los Asentamientos Humanos (UN-CNUAH) desarrolló la primera Cumbre Mundial sobre Asentamientos Humanos, en Vancouver Canadá; en respuesta a la Agenda Hábitat el gobierno motivó la creación en el año 1979, de un Programa de Vivienda y Asentamientos Humanos y se crea el Sector Vivienda y Asentamientos Humanos.

En 1981, mediante una norma presupuestaria en la Ley n. ${ }^{\circ} 6.542$, crea el Ministerio de Vivienda y Asentamientos Humanos (MIVAH). En 1986, nace el Sistema Financiero Nacional de la Vivienda (SFNV) y el Banco Hipotecario de la Vivienda (BANHVI), por medio de la Ley n. ${ }^{\circ}$ 7.052. Esta ley dio paso a nuevo actores (banca, Cooperativas, Mutuales, Fundaciones). Se crea un ins- 
trumento fundamental: el Bono Familiar de Vivienda (BFV), sistema que está formado por el BANHVI y las entidades autorizadas para gestionar el bono.

El bono familiar de vivienda que se crea en el año 1990, el cual "es un subsidio o ayuda que el Estado, en forma solidaria, otorga a las familias de escasos recursos económicos, clase media, personas con discapacidad, mujeres jefas de hogar y ciudadanos adultos mayores, para que unido a su capacidad de crédito, solucione sus problemas de vivienda" (MIVAH, 2018). El mismo se convierte en un instrumento esencial para dotar de vivienda a esta población; sin embargo, se ha analizado la verdadera pertinencia de que el bono sea gratuito; por un lado el fondo para la vivienda se vería fortalecido si los beneficiarios aportaran aunque sea una cuota mínima; y por otro lado falta de claridad en los mecanismos de selección de los beneficiaros que podrían beneficiar a familias injustamente, en detrimento de quienes en realidad lo necesitan.

El accionar del Estado en el tema de la dotación de vivienda y los asentamientos humanos queda expresa además en otras leyes; incluso muchos años antes que la propia creación del sistema nacional para la atención de la vivienda y otras de aprobación reciente; entre ellas destacan: 
Tabla 1: Costa Rica: Leyes que propician el accionar del estado en la dotación de vivienda social

\begin{tabular}{|c|c|c|}
\hline Ley & $\begin{array}{c}\text { Año de } \\
\text { aprobación }\end{array}$ & Ámbito/Accionar \\
\hline $\begin{array}{l}\text { Crea Cooperativa } \\
\text { denominada "Casas } \\
\text { Baratas La Familia". }\end{array}$ & $\begin{array}{l}\text { Ley n. }{ }^{\circ} 190 \\
\text { del } 14 \text { de } \\
\text { agosto de } \\
1942 .\end{array}$ & $\begin{array}{c}\text { Construcción, en la ciudad de San José, de casas } \\
\text { higiénicas a bajo precio para peones, obreros, artesanos } \\
\text { y empleados cuyo sueldo o salario no pase de ( } \$ 250.00) \\
\text { doscientos cincuenta colones al mes. }\end{array}$ \\
\hline $\begin{array}{l}\text { Ley n. }{ }^{\circ} 148, \text { "Crea } \\
\text { Departamento de la } \\
\text { Habitación de la Caja } \\
\text { Costarricense de } \\
\text { Seguro } \\
\text { Social (CCSS) para } \\
\text { Vivienda Popular". }\end{array}$ & $\begin{array}{l}\text { Ley } \mathrm{N}^{\circ} 148 \\
\text { de } 8 \text { de agosto } \\
\text { de } 1945 .\end{array}$ & $\begin{array}{c}\text { Establece impuesto a espectáculos públicos a favor } \\
\text { de municipalidades, reforma a la norma todos bienes } \\
\text { muebles e inmuebles, rentas y recursos de Junta } \\
\text { Nacional de la Habitación y “Cooperativas Casas } \\
\text { Baratas, La Familia”, pasará a la CCSS. }\end{array}$ \\
\hline Ley de Inquilinato. & $\begin{array}{l}\text { No } 680 \text { de } 3 \\
\text { de setiembre } \\
\text { de } 1946 .\end{array}$ & $\begin{array}{l}\text { Regla las relaciones derivadas de los contratos de } \\
\text { arrendamiento y de subarrendamiento de locales } \\
\text { comprendidos en los perímetros urbanos. }\end{array}$ \\
\hline $\begin{array}{l}\text { Ley Orgánica del } \\
\text { INVU. }\end{array}$ & $\begin{array}{l}\text { Ley } N^{\circ} 1788 \\
\text { del } 24 \text { de } \\
\text { agosto de } \\
1954 .\end{array}$ & $\begin{array}{c}\text { Proporcionar a las familias costarricenses que carezcan } \\
\text { de alojamiento adecuado y, en las condiciones normales, } \\
\text { de los medios necesarios para obtenerlo con sus propios } \\
\text { recursos, la posibilidad de ocupar en propiedad o en } \\
\text { arrendamiento, una vivienda que reúna los requisitos } \\
\text { indispensables a efecto de facilitar el desarrollo } \\
\text { y conservación de la salud física y mental de sus } \\
\text { moradores. }\end{array}$ \\
\hline $\begin{array}{l}\text { Ley de Erradicación de } \\
\text { Tugurios y Defensa de } \\
\text { sus Arrendatarios. }\end{array}$ & $\begin{array}{l}\text { Ley } \mathrm{N}^{\circ} 2760 \text {, } \\
\text { del } 16 \text { de } \\
\text { junio de } 1961 .\end{array}$ & $\begin{array}{l}\text { Utilidad pública todo lo relacionado con la satisfacción } \\
\text { de las necesidades de vivienda popular en las áreas } \\
\text { urbanas y rurales del país, y en especial lo que se } \\
\text { refiere a la erradicación de tugurios, a la defensa de sus } \\
\text { arrendatarios, a evitar la Formación de áreas de tugurios } \\
\text { y al fomento de la construcción de viviendas de precios } \\
\text { bajos. }\end{array}$ \\
\hline $\begin{array}{c}\text { Ley de Planificación } \\
\text { Urbana. }\end{array}$ & $\begin{array}{l}\text { Ley } \mathrm{N}^{\circ} 4240 \text {, } \\
\text { del } 15 \text { de } \\
\text { noviembre de } \\
1968 .\end{array}$ & $\begin{array}{c}\text { Norma lo relacionado con la planificación urbana, } \\
\text { desarrollo, expansión, distribución de la población, uso } \\
\text { del suelo urbano. }\end{array}$ \\
\hline
\end{tabular}




\begin{tabular}{|c|c|c|}
\hline Ley & $\begin{array}{c}\text { Año de } \\
\text { aprobación }\end{array}$ & Ámbito/Accionar \\
\hline $\begin{array}{l}\text { Ley de Impuesto sobre } \\
\text { Traspasos de Bienes } \\
\text { Inmuebles. }\end{array}$ & $\begin{array}{l}\text { Ley } \mathrm{N}^{\circ} 6999 \\
\text { del } 3 \text { de } \\
\text { septiembre de } \\
1985 .\end{array}$ & $\begin{array}{l}\text { Exime del impuesto los traspasos de inmuebles a } \\
\text { personas físicas, destinados a vivienda popular. }\end{array}$ \\
\hline $\begin{array}{l}\text { Ley del Sistema } \\
\text { Financiero Nacional } \\
\text { para la Vivienda y su } \\
\text { Reglamento. }\end{array}$ & $\begin{array}{l}\text { Ley } \mathrm{N}^{\circ} 7052 \text {, } \\
\text { del } 13 \text { de } \\
\text { noviembre de } \\
1986 .\end{array}$ & $\begin{array}{c}\text { Fomentar el ahorro y la inversión nacional y extranjera, } \\
\text { con el fin de recaudar recursos financieros para procurar } \\
\text { la solución del problema habitacional existente en el } \\
\text { país, incluido el aspecto de los servicios. }\end{array}$ \\
\hline $\begin{array}{l}\text { Ley de Presupuesto } \\
\text { Ordinario y } \\
\text { Extraordinario de la } \\
\text { República. }\end{array}$ & $\begin{array}{l}\text { Ley No } 8627 \text {, } \\
\text { año } 2007 .\end{array}$ & Crea el Programa de Bono Colectivo. \\
\hline $\begin{array}{c}\text { Ley Especial para } \\
\text { Titulación de Vivienda } \\
\text { en Precarios y en Zonas } \\
\text { de Desarrollo Urbano } \\
\text { no Reconocidas } \\
\text { (precarios). }\end{array}$ & $\begin{array}{l}\text { Ley } \mathrm{N}^{\circ} 8680 \\
\text { del } 12 \text { de } \\
\text { noviembre de } \\
2008 .\end{array}$ & $\begin{array}{c}\text { Regula lo pertinente solo para aquellos terrenos } \\
\text { ocupados por personas físicas en carácter de precaristas } \\
\text { así identificados. }\end{array}$ \\
\hline $\begin{array}{l}\text { Ley sobre el Impuesto } \\
\text { Solidario para el } \\
\text { Fortalecimiento } \\
\text { de Programas de } \\
\text { Vivienda. }\end{array}$ & $\begin{array}{l}\text { Ley } \mathrm{N}^{\circ} 8683 \\
\text { del } 19 \text { de } \\
\text { noviembre de } \\
2008 .\end{array}$ & $\begin{array}{l}\text { Para financiar los programas públicos dirigidos a la } \\
\text { dotación de vivienda digna, para personas y familias en } \\
\text { condición de pobreza y pobreza extrema. }\end{array}$ \\
\hline $\begin{array}{l}\text { Ley del Sistema } \\
\text { Financiero Nacional } \\
\text { para la Vivienda } \\
\text { y Creación del } \\
\text { BANHVI. }\end{array}$ & $\begin{array}{l}\text { Ley } \mathrm{N}^{\circ} 8936 \\
\text { del } 21 \text { de } \\
\text { junio del } \\
2011 .\end{array}$ & $\begin{array}{c}\text { Incorpora a las asociaciones solidaristas como entidades } \\
\text { autorizadas del Sistema para tramitar el Bono Familiar } \\
\text { de Vivienda (BFV). }\end{array}$ \\
\hline $\begin{array}{l}\text { Ley de Creación de un } \\
\text { Bono para Segunda } \\
\text { Vivienda Familiar que } \\
\text { Autoriza el Subsidio } \\
\text { del Bono Familiar en } \\
\text { Primera y Segunda } \\
\text { Edificación. }\end{array}$ & $\begin{array}{l}\text { Ley } \mathrm{N}^{\circ} 8957 \\
\text { del } 31 \text { de } \\
\text { agosto del } \\
2011 .\end{array}$ & $\begin{array}{l}\text { Crea un subsidio de bono para segunda vivienda } \\
\text { familiar, que soporte una segunda vivienda familiar, y } \\
\text { el Régimen Especial de vivienda de interés social, sobre } \\
\text { un inmueble o edificación que soporte dos viviendas } \\
\text { destinadas a dos grupos familiares. }\end{array}$ \\
\hline
\end{tabular}




\begin{tabular}{|c|c|c|}
\hline Ley & $\begin{array}{c}\text { Año de } \\
\text { aprobación }\end{array}$ & Ámbito/Accionar \\
\hline $\begin{array}{l}\text { Ley de Modernización } \\
\text { de los mecanismos } \\
\text { para el desarrollo de } \\
\text { vivienda de clase media } \\
\text { mediante la reforma } \\
\text { del artículo } 5 \text { de la Ley } \\
\text { 1788, Ley Orgánica del } \\
\text { Instituto Nacional de } \\
\text { Vivienda y Urbanismo. }\end{array}$ & $\begin{array}{l}\text { Ley } N^{\circ} 8960 \\
\text { del } 2011 .\end{array}$ & $\begin{array}{l}\text { El INVU queda facultado para traspasar, a título } \\
\text { gratuito, las áreas públicas y comunales de sus programas } \\
\text { a la entidad que corresponda, las que se tendrán como } \\
\text { parte del porcentaje que debe cederse para parques y } \\
\text { facilidades comunales, según las leyes o los reglamentos } \\
\text { de urbanización y fraccionamiento.” }\end{array}$ \\
\hline $\begin{array}{l}\text { Ley de Creación } \\
\text { del Fondo para el } \\
\text { Financiamiento de } \\
\text { Viviendas de Primera } \\
\text { Solución para la Clase } \\
\text { Media. }\end{array}$ & $\begin{array}{l}\text { Ley } \mathrm{N}^{\circ} 9157 \\
01 \text { de octubre } \\
2013 \text {. }\end{array}$ & $\begin{array}{l}\text { Crea el Fondo para el financiamiento de vivienda para } \\
\text { clase media. Los bancos públicos, las mutuales, las } \\
\text { cooperativas y los bancos privados interesados podrán } \\
\text { constituir un Fondo de Financiamiento de Vivienda } \\
\text { para Clase Media (Fofivi), que brinde crédito a la clase } \\
\text { media, a fin de ofrecerle una primera solución a sus } \\
\text { necesidades de vivienda. }\end{array}$ \\
\hline \multicolumn{3}{|c|}{ Otras leyes que promueven el acceso a la vivienda } \\
\hline $\begin{array}{l}\text { Ley de Atención a } \\
\text { Mujeres en Condición } \\
\text { de Pobreza. }\end{array}$ & $\begin{array}{l}\text { Ley } \mathrm{N}^{\circ} 7769 \text {, } \\
\text { del } 24 \text { de abril } \\
\text { de } 1998 .\end{array}$ & $\begin{array}{c}\text { Promueve mejoramiento en las } \\
\text { condiciones de vida de las mujeres, mediante un proceso } \\
\text { de formación integral que } \\
\text { Comprenda, al menos, lo siguiente: capacitación en } \\
\text { formación humana, capacitación técnico laboral, } \\
\text { inserción laboral y productiva, acceso a vivienda digna } \\
\text { y un incentivo económico ligado a los procesos de } \\
\text { capacitación. }\end{array}$ \\
\hline $\begin{array}{l}\text { Ley Integral para la } \\
\text { Persona Adulta Mayor. }\end{array}$ & $\begin{array}{l}\text { Ley } \mathrm{N}^{\circ} 7935 \\
\text { del } 25 \text { de } \\
\text { octubre de } \\
1999 .\end{array}$ & $\begin{array}{l}\text { El adulto mayor tiene derecho a una vivienda digna, } \\
\text { apta para sus necesidades, y que le garantice habitar en } \\
\text { entornos seguros y adaptables. }\end{array}$ \\
\hline $\begin{array}{l}\text { Ley General de la } \\
\text { Persona Joven. }\end{array}$ & $\begin{array}{l}\text { Ley } N^{\circ} 8261 \\
\text { del } 2 \text { de mayo } \\
\quad \text { de } 2002 .\end{array}$ & $\begin{array}{l}\text { Promover el acceso equitativo de la persona joven a los } \\
\text { servicios básicos que favorezcan su desarrollo integral. }\end{array}$ \\
\hline
\end{tabular}

Fuente: Elaboración a partir de revisión bibliográfica, 2018.

En el año 2007, por medio de la aprobación de la Ley de Presupuesto Ordinario y Extraordinario de la República (Ley n. ${ }^{\circ}$ 8.627), se crea el Programa de Bono Colectivo; el cual se aplica a los asentamientos, en condición de 
precariedad, de manera colectiva, para la dotación y mejora de la infraestructura social. Faculta, al Sistema Financiero Nacional de la Vivienda (SFNV), a hacer inversión en: las redes y los sistemas para la provisión de servicios básicos de saneamiento, energía y comunicación, equipamiento social, las redes internas y externas de comunicación con los distintos sectores de la comunidad y su comunicación con otras comunidades, las zonas verdes y recreativas para el mejoramiento de la calidad vida, el equipamiento productivo, referido al conjunto de instalaciones comunitarias o estatales donde se desarrollan actividades productivas o partes fundamentales del ciclo productivo. Un programa que pareciera muy pertinente para el logro de un desarrollo integral de las familias; está siendo cuestionado por los medios de prensa; dado que según la opinión el dinero destinado para este fin, debe redireccionarse para la solución de viviendas familiares.

Asimismo se promulgan otras leyes que promueven el acceso a la vivienda de sectores específicos y bajo condiciones diferenciadas; como la atención a mujeres en condición de pobreza, ley persona adulto mayor, ley de la persona joven.

A pesar de estos esfuerzos de dotar de vivienda a la población, los asentamientos informales es un tema no resuelto. Según datos del MIVAH, en el año 1987 existían 13.800 familias habitando en 104 asentamientos informales; para el año 2011, 39.054 familias habitaban en 354 asentamientos, de este total aproximadamente un 60\% se ubicaban en el Gran Área Metropolitana. La mayoría de estos asentamientos surgieron en las décadas de los 80 y de los 90; lo que significa que la problemática se ha acrecentado.

Según FUPROVI (2016), en caso de no haber existido SFNV, el déficit habitacional sería de un 49\%. En 26 años un 30\% del total de la población ha tenido acceso a vivienda, por medio de un subsidio estatal, esto constituye aproximadamente 300.000 familias, 1.250 .000 personas (FUPROVI, 2016).

\section{La vivienda en el marco de la creación del Sistema Nacional del Hábitat Humano}

El establecimiento de un marco legal e institucional en torno al sector vivienda en un contexto más amplio como lo es el ordenamiento territorial y con la rectoría bajo un mismo Ministerio de Vivienda y Asentamientos Humanos; propone un sector vivienda con mayores posibilidades de articular acciones y 
ofrecer una mejor calidad de vida a los habitantes. Mediante la reforma al Decreto Ejecutivo n. 34.582 Reglamento Orgánico del Poder Ejecutivo, se estableció el Sector de Ordenamiento Territorial y Vivienda, en la Gaceta n. ${ }^{\circ}$ 137, del 15 de julio del 2011, estará bajo la rectoría del Ministro o la Ministra de Vivienda y Asentamientos Humanos.

Según lo establecido en la Directriz n. ${ }^{\circ} 006$ de la Presidencia de la República y MIDEPLAN, el Sector Vivienda y Asentamientos Humanos está conformado por instituciones centralizadas y descentralizadas: Ministerio de Vivienda y Asentamientos Humanos (MIVAH), Banco Hipotecario de la Vivienda (BANHVI), Instituto Nacional de Vivienda y Urbanismo (INVU), Comisión Nacional de Prevención de Riesgos y Atención de Emergencias (CNE) e Instituto de Fomento y Asesoría Municipal (IFAM); siendo el Rector del Sector el Ministro de Vivienda y Asentamientos Humanos (Gobierno de la República, 2014, p. 249).

A pesar de la institucionalidad y la normativa existente alrededor del tema de vivienda; de acuerdo al Plan Nacional de Desarrollo 2015-18, con respecto al sector de Vivienda y Asentamientos Humanos; "son tres aspectos que afectan fundamentalmente el sector vivienda: a) Un sistema ineficiente para atender las necesidades de vivienda en el país, que deja desamparada a una porción de la población con necesidades extremas. b) Una clase media que no está siendo atendida en su necesidad de vivienda pues no cuenta con opciones habitacionales ni de financiamiento apropiado y c) Asentamientos humanos no planificados, con problemas que comprometen su competitividad" (Gobierno de la República, 2014, p. 249)”.

Por su parte, en la Gaceta n. ${ }^{\circ}$ 47, del 7 de marzo de 2014, se oficializa la Política Nacional de Vivienda y Asentamientos Humanos PNVAH 20132030. La Política se ha estructurado en cinco ejes: político-administrativo, sociocultural, ambiental, físico-espacial y económico-financiero.

En el eje político-administrativo, destaca la consolidación de un Sistema Nacional del Hábitat Humano, con un sistema de información que pretende tener una visión de país, y no solamente de las áreas urbanas del Gran Área Metropolitana y algunas regiones urbanas periféricas; y los trámites y participación que se derivan de este sistema. 
En el eje sociocultural, destaca los temas de integración y cohesión social, diversidad y vulnerabilidad, género y vivienda, mejoramiento de barrios y vivienda indígena.

En el eje físico-espacial, se integra el tema de déficit habitacional, el deterioro estructural de la vivienda, la renovación urbana, infraestructura, servicios sociales, equipamiento urbano y espacios públicos, las ciudades compactas, ordenamiento territorial, diseño y calidad de la inversión pública en materia de vivienda y asentamientos humanos. En algunos de estos temas se han dado pasos importantes; un ejemplo es la aprobación en el año 2017 del Reglamento de Renovación Urbana; otros temas siguen sin resolverse como lo es el ordenamiento territorial; se espera que con la aprobación del nuevo Manual de Planes reguladores como instrumento de Ordenamiento territorial publicado en la Gaceta oficial del 31 de enero del 2018, por parte del Instituto Nacional de Vivienda y Urbanismo, acompañado de otras instituciones de relevancia en el tema como la Secretaría Técnica Ambiental (SETENA) y Sistema Nacional de Riego y Avenamiento (SENARA); un instrumento más flexible y que se agilicen las solicitudes por parte de las municipales para la aprobación de los planes reguladores municipales.

En el eje ambiental se prioriza sobre la prevención de riesgo y las viviendas afectadas por desastres, el cambio climático y la gestión residencial del recurso hídrico. Temas que por sus implicaciones territoriales son de relevancia nacional.

En el eje económico financiero se plantean temas como financiamiento para los programas de vivienda, acceso a la vivienda para la clase media, acceso a terrenos, titulación y mercado secundario de hipotecas. Destaca entre ellos las opciones para acceso a vivienda de la clase media, estrato que no se ha considerado lo suficiente con las políticas de acceso a la vivienda.

Este Sistema Nacional del Hábitat Humano estará articulado por el MIVAH, como el ente rector de la PNVAH; con el apoyo de instituciones del Estado de convocatoria permanente, instituciones públicas estatales y no estatales, instituciones regionales y locales y un sector privado, cuya participación es de gran relevancia en el tema.

Según la Política Nacional de Vivienda y Asentamientos Humanos (PNVAH) (MIVAH 2014) plantea que temas como: la renovación urbana, el desarrollo rural, la regeneración y repoblamiento de ciudades, el mejoramiento de barrios y la creación de ciudades compactas, entre otros factores, deben ser 
incluidos como prioritarios, en las agendas nacionales, regionales y locales de desarrollo.

De relevancia para el sector vivienda fue la aprobación en el año 2011, mediante el Decreto Ejecutivo n. ${ }^{\circ}$ 36.550-MP-MIVAH-S-MEIC se crea un nuevo Reglamento para la Tramitación de Planos de Proyectos de Construcción; reglamento que acorta plazos de 6 meses a 1 mes en la tramitación de permisos de construcción.

Asimismo recientemente en 2017 se aprueba Reglamento de Renovación Urbana. En su artículo 1, enuncia como objetivo "complementar las herramientas establecidas en el artículo 21 de la Ley de Planificación Urbana, y fijar las normas que deberán adoptarse para rehabilitar, remodelar o regenerar las áreas urbanas disfuncionales, o conservar áreas urbanas, cuya intervención sea considerada estratégica por parte de los gobiernos municipales o el Estado" (INVU, 2017, p. 1).

La Nación, 5 noviembre, 2016, resumen que en el foro sobre las lecciones de Hábitat III se proponen como conclusiones relevantes: a) asistencialismo y regulación, el rol central del sector privado en la satisfacción de demandas de mercado y el rol regulador del estado, b) Rehabilitación urbana, que generaría impactos positivos en la seguridad ciudadana y en la rehabilitación de espacios públicos y parques. d) Prevención de riesgo; la ubicación de proyectos en áreas que contemplen esta variable.

De esta manera, y de relevancia para el país en materia normativa y de ejecución; ha sido la aprobación de la Política Nacional de Ordenamiento Territorial, que junto a la presente Política Nacional de Vivienda y Asentamientos Humanos; se convierten en dos ejes del desarrollo urbano; en términos de la planificación y en materia de vivienda. Aunque los esfuerzos por lograr procesos acordes a las áreas urbanas continúan, el tema del ordenamiento territorial no termina de concretarse en propuestas de un uso adecuado del suelo y de mayores beneficios para la población. Habrá que esperar algunos años, para conocer si estas políticas impactan como es de esperar los territorios. 


\section{El sector de la vivienda en Costa Rica}

La vivienda considerada como una necesidad básica; según el INEC (2017), Encuesta Nacional de Hogares (ENAHO), 2017; en Costa Rica se registran 1,496.053 vivienda, con 4, 946,700 ocupantes (un promedio de 3,3 habitantes por vivienda). De estas un $62,95 \%$ son viviendas propias, propias pagando a plazo un $10 \%$, alquilada $17,21 \%$, en precario $1,39 \%$ y otra tenencia $8,43 \%$, (cedidas o prestadas).

Un $53,59 \%$ de estas viviendas son individuales, $2,47 \%$ en condominio o residencial cerrado, 4,12\% en fila o contigua, $0,0021 \%$ en edificio (incluye viviendas en condómino vertical y apartamentos), y $0,0051 \%$ en otro tipo de vivienda (cuarterías, tugurios u otros).

Según el estado físico de las viviendas estas se clasifican en $60,15 \%$ como bueno, 30,72\% en estado regular y $9,12 \%$ en mal estado. Un $97,63 \%$ se considera como vivienda no hacinada frente a un $2,36 \%$ en condición de hacinamiento.

El sector vivienda es el de mayor dinamismo, en cuanto a las construcciones que genera sobre otros sectores de la economía. De acuerdo a los datos del Colegio Federado de Ingenieros y Arquitectos (CFIA), (2017) sobresale los metros de construcción habitacional, urbanístico y comercial; un bajo crecimiento en sector turístico y agroindustrial. El sector habitacional aunque mantiene el porcentaje más alto, manifiesta un descenso en el período 2015-17, pasando de $42,86 \%$ en 2015,40 , $92 \%$ en $2016,34,60 \%$ en 2017 . Otros metros de construcción presentan porcentajes menores como sector salud, religioso, obras complementarias, sanitarias y deportivas.

Asimismo los permisos de construcción entre los años 2015-17 mantienen una tendencia a aumentar en el uso habitacional casa, pasando de $51,79 \%$ en $2015,53,57 \%$ en el 2016 y $60,72 \%$ en el 2016 y una disminución en el porcentaje de metros de construcción en condominio, pasando de $22,21 \%$ en el 2015 a $15,69 \%$ para apartamentos y condominios. Lo que evidencia que este último tipo de ocupación sigue siendo un porcentaje menor en la preferencia habitacional, y se mantiene la tendencia de un crecimiento residencial horizontal; las construcciones en condominios aunque se valora han crecido no es suficiente para motivar una renovación de espacios urbanos y ocupar áreas centrales de las principales ciudades. 
Los condominios se promueven como una solución residencial para clase media, que como se ha mencionado, es un sector desatendido por la política de vivienda; y agrupa a la población de estrato 4 al 6 .

Los metros de construcción en casa de interés social exonerada se mantuvo, pasando de $13,86 \%$ en 2015 , a $13,72 \%$ en 2017 . El monto del bono de la vivienda para el año 2016 era de 6.500 .000 colones un equivalente a $\$ 11.403,5088$ dólares. En su mayor parte destinado a construcción de vivienda en lote propio.

Según FUPROVI (2016), "Dentro del proceso que genera la construcción habitacional, los Bonos Familiares de Vivienda tienen un fuerte peso, por ejemplo, en los años de recesión de la construcción habitacional (a partir 2009), los bonos entregados llegaron a representar casi el 60\% del total de viviendas construidas" (p. 31).

En otras opciones para los estratos bajos, según FUPROVI (2017), "el Gobierno pretende mediante un proyecto de ley que se encuentra en la Asamblea Legislativa crear los alquileres sociales, que sería una solución para disminuir las cuarterías" (p. 5); ya que según esta información alrededor de 11 mil personas viven en cuarterías, que presentan alto riesgo de incendio y un alto hacinamiento, serían soluciones habitacionales en mejores condiciones y a precio accesible para esta población.

FUPROVI (2017), señala que "de acuerdo con los datos del INEC, las casas de más de $80 \mathrm{~m} 2$ quedaron el olvido, las viviendas entre $40 \mathrm{y}$ $70 \mathrm{~m} 2$ han aumentado en un 35\% en el último período, dejando atrás las casas mayores a $150 \mathrm{~m} 2$. La seguridad, eficiencia de espacio y altos costos de construcción son algunas de las razones que apoyan este cambio" ( $p$. $10)$.

\section{Servicio Financiero Nacional de la Vivienda (SFNV) Social}

El gasto en vivienda es entre $9 \%$ y un $10 \%$ del gasto social total del país, ocupa el cuarto lugar, le anteceden los montos invertidos en educación, salud y asistencia social; a pesar de esta inversión en el sector vivienda se considera que persiste el déficit habitacional tanto cuantitativo como cualitativo (Mata y Trejos, 2017).

Los lineamientos de política pública para dotar de recursos financieros al sector de vivienda social, se insertan en el sistema a través del BANHVI, en el 
cual el Ministro de Vivienda asume el rol de presidente de la Junta Directiva. La Ley 7.052 del 13 noviembre de 1986, crea el Sistema Financiero Nacional para la Vivienda y el Banco Hipotecario de la Vivienda (BANHVI), como institución rectora. El BANVHI es una entidad de interés público, regida por dicha ley, En la ley de creación del BANHVI, (1986) en su artículo 1, señala que:

Tendrá como objetivo principal fomentar el ahorro y la inversión nacional y extranjera, con el fin de recaudar recursos financieros para procurar la solución del problema habitacional existente en el país, incluido el aspecto de los servicios, asimismo en el artículo 2, El Sistema Financiero Nacional para la Vivienda estará integrado por el Banco Hipotecario de la Vivienda, como ente rector, y por las entidades autorizadas previstas en esta ley (p. 1).

Para distribuir los recursos financieros y dar sostenimiento al sistema de vivienda, se creó el Fondo Nacional de Vivienda (FONAVI) y el Fondo de Subsidio para la Vivienda (FOSUVI) y el Fondo de Desarrollo Social y Asignaciones Familiares (FODESAF), que aporta el 35\% de los recursos promocionales que se destinan al mejoramiento del hábitat. (Mata y Trejos, 2017). Además, la ley del SFNV crea una red de instituciones públicas y privadas, para dotar de vivienda a las familias de menores ingresos.

Con la creación de BANHVI como ente rector del sistema financiero nacional de la vivienda; articula una serie de instituciones y organizaciones entre ellos los entes autorizados del sistema (cooperativas, mutuales, banca, fundaciones). Las cuales tienen como finalidad atender los potenciales beneficiarios de los programas de ahorro, bono y crédito, para el acceso a la vivienda. Por ley están autorizados para calificar a los beneficiarios y postularlos para el Bono de la Vivienda, tramitar proyectos de vivienda que le son presentados por los desarrolladores de vivienda ante el BANHVI. Las mutuales y las cooperativas se mantienen a la vanguardia en la colocación de créditos para bono de vivienda.

A nivel general el Sistema Financiero Nacional para la Vivienda está organizado con la Contraloría General de la República y el BANVHI que articula al MIVAH y SUGEF, en un nivel inferior las entidades autorizadas, grupos organizados pro-vivienda, los desarrolladores y beneficiarios del bono de la vivienda. Articula además, otros sectores asociados como los ministerios e instituciones públicas; municipalidades, organizaciones de desarrollo comunal 
y organizaciones indígenas; vincula además; un sector financiero bancario compuesto por bancos públicos y privados, cámara de bancos, Cooperativas de ahorro y préstamo y asociaciones solidaristas; el sector de Organizaciones No Gubernamentales (ONG), e instituciones para la rendición de cuentas.

Entre los actores relevantes, por su impacto en el desarrollo de los proyectos de vivienda están las empresas desarrolladoras de proyectos de interés social, que tiene como función formular y ejecutar los proyectos de vivienda, a través de los programas de vivienda estatales. Así como las fundaciones desarrolladoras de proyectos de interés social; que además de formular y ejecutar proyectos de vivienda, tienen la función de realizar investigación y proponer mejoras en el sistema o brindar asesoría, es el caso de FUPROVI. Uno de los aspectos más crítico en el sistema de financiamiento, es la falta de control del sector inmobiliario en el desarrollo de proyectos residenciales dado que carecen de fiscalizaciones mínimas agudizando temas de calidad de la vivienda y las condiciones de ubicación en áreas de riesgo. En la Agenda Hábitat III, uno de los puntos medulares de retomar es el rol regulador del estado, ante el rol central del sector privado en la satisfacción de demandas de mercado. Se requiere según FUPROVI (2017) un mayor involucramiento de la organización comunal en la localización de proyectos residenciales y diseño de los mismos.

Según datos de FUPROVI (2013, p. 10),

el país no ha logrado satisfacer la demanda de vivienda adecuada en los diferentes estratos de ingresos de la población. Un 70\% de los hogares cuenta con vivienda propia, mientras que el restante $30 \%$ habita en viviendas que no son de su propiedad. Del total de hogares con vivienda propia, un $42 \%$ de ellos forman parte del Déficit Cualitativo Real.

El Informe final Hábitat III, el MIVAH - Gobierno de la República de Costa Rica (2016), señala que: "las tipologías de vivienda de interés social han respondido a criterios físicos y no a criterios sociales; por tanto no atiende en muchos casos la demanda de los beneficiarios. El último Censo Nacional 2011, entre sus principales hallazgos indica, que existen al menos 16 distintos tipos de núcleos familiares" (p. 50). Debe rescatarse según este mismo informe el diseño de soluciones habitacionales, en los cuales prevalezca el concepto de diseño funcional; integrando el contexto físico-espacial. 
Según diagnóstico realizado por MIDEPLAN (2014), la ineficiencia del Sistema Financiero Nacional para la Vivienda (SFNV);

Con respecto a la atención de la población de los estratos 1 y 2 en extrema pobreza, su atención se rige por una dinámica que deja en manos de los constructores privados la selección de los beneficiarios, así como las decisiones sobre el tipo de oferta disponible en el mercado (tipología de las vivienda) y el lugar donde será satisfecha la demanda por viviendas. En este escenario el Estado pierde la oportunidad de incidir y direccionar más eficientemente el desarrollo del país. La clase media tipificada en este mismo diagnóstico en el estrato 3 a 6 , ha dejado en manos del sector privado la atención de este sector. La incidencia en el desarrollo urbano planificado se reduce, tanto en la GAM como en las ciudades intermedias; se dejan de lado proyectos que permitirían densificar la ciudad en altura media, en sustitución de un modelo horizontal; y con esto se contribuiría a la renovación de centros urbanos degradados. (Gobierno de la República, 2014, p. 250).

Según estudio realizado por el MIVAH (2012),

En el cantón de Montes de Oca, señala que para la clase media 'la oferta del mercado inmobiliario no suele adaptarse a los escenarios reales de los hogares del estrato socioeconómico medio, a partir de sus gustos y aspiraciones y su capacidad de endeudamiento, por lo que los hogares deben ajustar sus expectativas a dicha oferta, o bien optar por alternativas de alquiler, permanecer en sus hogares de origen o compartir la vivienda con otros hogares' (p. 22).

Según este mismo estudio, MIVAH (2012): es un grupo de población con características diferenciadas de nivel educativo, ocupación, lugar de residencia, que lo diferencia de los demás grupos; en el tema de vivienda construye sus propias expectativas, que no se concilian con sus gustos y las posibilidades financieras del hogar. Se hace necesario por tanto, desarrollar programas o acciones específicas para atender este estrato de población que no tiene acceso a la vivienda. 


\section{El bono de la vivienda: características y distribución geográfica}

Definido por el BANVHI, 2018, “el bono de vivienda es una donación que el Estado Costarricense otorga en forma solidaria a familias de ingresos bajos y medios, para que, unido a su capacidad de crédito, solucionen su problema de vivienda. El monto del bono depende de los ingresos familiares, el monto máximo actual es de $\$ 6.500 .000 ”$ (p. 2). Equivalente a $\$ 11.403,5088$, según tipo de cambio.

Según Directriz n. ${ }^{\circ}$ 27, en su artículo 2.- Población Objetivo, "el perfil de las familias que el MIVAH desea impulsar en el desarrollo de proyectos habitacionales financiados mediante la aplicación del Artículo 59 de la ley del SFNV es, preferiblemente, familias con ingresos inferiores al estrato 1 a 5 (1-5 salarios mínimos)" (p. 2).

De acuerdo al (BANVHI, 2018); el bono de la vivienda puede ser utilizado para: comprar lote y construir, comprar casa nueva o usada, construir en terreno propio, construir o reparar casa en lote de un familiar y reparar, ampliar o mejorar la casa propia. Los solicitantes deben formar parte de un núcleo familiar, no tener casa propia o más de una propiedad, no haber recibido un bono anteriormente, ingreso mensual menor a $\$ 1.569 .474$ al mes $(\$ 2.724,78)$, costarricense o situación de residencia legalizada y realizar la solicitud ante el BANVHI. Además se tienen programas especiales de bono de la vivienda: Programa de Reparación, ampliación, mejora o terminación de casa propia (PROGRAMA RAMT), Programa para personas adultas mayores, Programa para familias con algún miembro con discapacidad Bono de segunda planta o segunda vivienda.

El bono es otorgado a las familias en matrimonio u unión libre o el núcleo familiar constituido por la madre y sus hijos. Solamente se puede tramitar en entidades autorizadas por el BANVHI y sus entidades autorizadas. Según datos del BANVHI (2018), son veinte y cuatro entidades autorizadas para tramitar el bono de vivienda.

Con el fin de proteger el patrimonio de la vivienda otorgadas mediante el bono, se crearon mecanismos de protección a la vivienda y las familias que reciben el beneficio del bono de la vivienda; en la siguiente tabla se mencionan dichas características; inembargabilidad, régimen del patrimonio familiar, limitaciones del BANVHI y las exenciones fiscales (véase Tabla 2). 
Tabla 2: Rica: Características de la vivienda financiada con el bono de la vivienda (2016)

\begin{tabular}{|c|c|}
\hline Características & Mecanismos de protección \\
\hline Inembargabilidad & $\begin{array}{l}\text { Por } 10 \text { años a partir de la firma de la escritura, esto como un } \\
\text { medio de protección a las viviendas financiadas con el bono. }\end{array}$ \\
\hline El régimen del patrimonio familiar & $\begin{array}{l}\text { Inscribir la casa a nombre de la pareja como parte del } \\
\text { patrimonio familiar en casos de matrimonio u unión libre, } \\
\text { no podrá ser vendida ni hipotecada sin el consentimiento } \\
\text { de ambos cónyuges. La afectación a la vivienda termina } \\
\text { cuando haya mutuo acuerdo por los conyugues o los hijos. }\end{array}$ \\
\hline Limitaciones del BANVHI & $\begin{array}{l}\text { Limita a la familia a no vender, alquilar, traspasar o } \\
\text { hipotecar la vivienda, sin autorización de la entidad } \\
\text { autorizada donde se realizó el trámite por un periodo de } \\
10 \text { años a partir de la firma de la escritura. Al ser vendida } \\
\text { o trasladada a otra familia recae en esta con las mismas } \\
\text { condiciones, no podrá ser vendida ni traspasada hasta } \\
\text { transcurridos } 10 \text { años del plazo original. }\end{array}$ \\
\hline Exenciones fiscales & $\begin{array}{l}\text { Exenciones en honorarios profesionales, inscripción de } \\
\text { escritura, construcción de vivienda, y los impuestos de la } \\
\text { Ley de Bienes Inmuebles. } \\
\text { Pago del } 50 \% \text { de honorarios profesionales, } 100 \% \text { en } \\
\text { inscripción de la escritura, exención de pago en los derechos } \\
\text { de construcción de viviendas: exención del pago de derechos } \\
\text { de catastro de planos, timbres fiscales y de construcción, } \\
50 \% \text { del pago de permisos de construcción y urbanización } \\
\text { y de todo otro impuesto. Exención la Ley de Bienes } \\
\text { Inmuebles, no pago de impuesto en el valor máximo es de } \\
\$ 19,089.000 \text { de la vivienda. }\end{array}$ \\
\hline
\end{tabular}

Fuente: Elaborado a partir de BANVHI, 2016.

Según el BANVHI, (2017), el tipo de Bono Familiar de la Vivienda, se distribuye según las características de ingreso de las familias: a) el bono completo es aquel que cubre la totalidad de los costos de compra de lotes y construcción de la vivienda, bono que es asignado a familias en extrema pobreza, y aquellas que han sido víctimas de fenómenos naturales; desde el año 1990, este es un bono gratuito. b) bono parcial puede utilizarse para la compra de vivienda existente, para compra de terreno y construcción de la casa, el monto del 
bono depende de los ingresos del grupo familiar. c) RAMT, este se aplica para ampliaciones o reparaciones de una vivienda existente; d) ABC este requiere del cumplimiento de una meta de ahorro establecida de previo, a partir del cual se entrega el bono estatal. El beneficiario debe adquirir un crédito por una parte del costo, con una entidad autorizada. f) El Bono Comunal es el bono aplicable en comunidades que poseen frágiles condiciones sanitarias y ambientales, con una condición de riesgo social inminente para sus habitantes. g) El Bono Diferido se utiliza en la amortización parcial de la cuota mensual a pagar por el crédito obtenido, en lugar de aplicarlo al valor de la solución habitacional.

De la información obtenida de las estadísticas del BANVHI, considerando que en Costa Rica cada gobierno es elegido por un período de cuatro años, se agrupó la información en períodos presidenciales, y dado que el último año de gobierno finaliza en el mes de mayo, este se suma al período siguiente. De acuerdo a esta información se parte del año 1986 año en que se establece el BANVHI, se tiene como períodos de gobierno; 1986-90 (Óscar Arias Sánchez), 1990-94 (Rafael Ángel Calderón Fournier), 1994-98 (José María Figueres Olsen), 1998-2002 (Miguel Ángel Rodríguez Echeverría), 2002-06 (Abel Pacheco de la Espriella), 2006-10 (Óscar Arias Sánchez), 2010-14 (Laura Chinchilla Miranda) y 2014-18 (Luis Guillermo Solís Rivera). En el período 1990-93 y 1994-97, fue el momento en el que se asignaron mayor cantidad de bonos de vivienda. En el año 1990 se declara gratuito el bono para sectores de la población según el estrato económico, esto incentivó a que los beneficiarios presentaran sus solicitudes para ser avaladas por el ente autorizado. A pesar de la disminución en la distribución de bonos en el último período, la asignación en colones aumentó; caracterizado principalmente por la devaluación de la moneda y la asignación de una mayor cantidad de dinero para el bono otorgado a los beneficiarios (véase figura 1). 
Figura 1: Costa Rica. Total de bonos otorgados por BANVHI. 2018

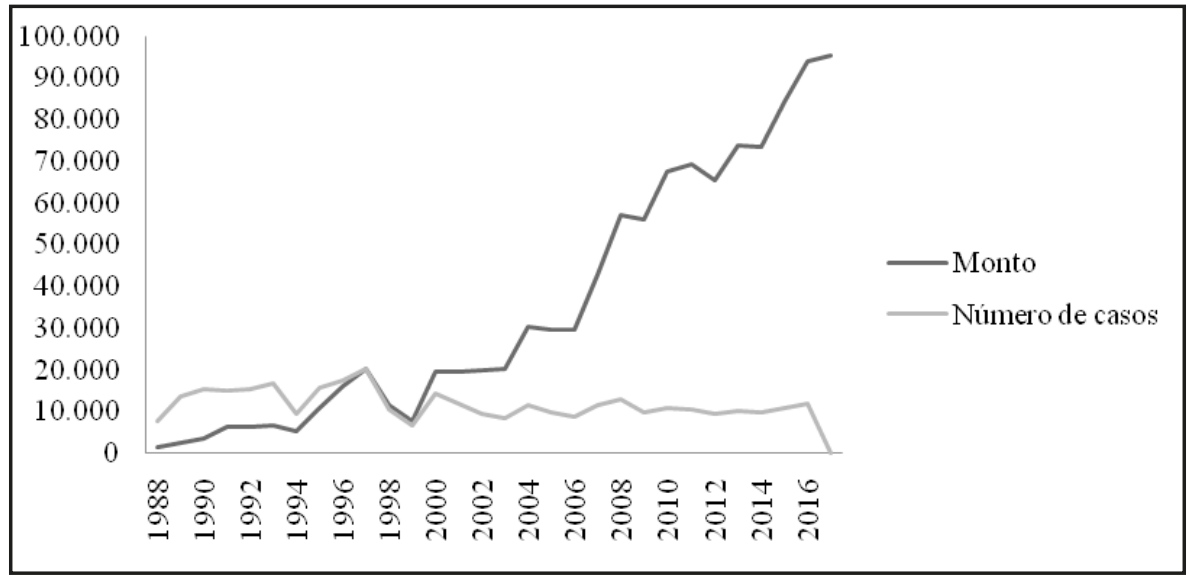

Fuente: Elaborado a partir de BANVHI (2018).

Con respecto a la cantidad de bonos familiares de vivienda pagados por estrato, se observa a nivel general que en la Tabla 3, estratos 1 y 2 es decir, en extrema pobreza, es en los cuales históricamente se han distribuido mayor cantidad de bonos; sin embargo este se considera como un estrato con mayor déficit habitacional; mientras que los estratos 5 y 6 tipificada como clase media reciben una asignación baja.

Tabla 3: Costa Rica: Cantidad de bonos familiares de vivienda pagados por estrato, 1987 al 2017

\begin{tabular}{cccccccc}
\hline Año & Total & Estrato 1 & Estrato 2 & Estrato 3 & Estrato 4 & Estrato 5 & Estrato 6 \\
\hline $1987-1989$ & 21.112 & 6147 & 7531 & 4050 & 3293 & 88 & 3 \\
$1990-1993$ & 62.546 & 27.158 & 20.534 & 9.214 & 5067 & 549 & 24 \\
$1994-1997$ & 62.688 & 40.411 & 19.436 & 2365 & 475 & 1 & 0 \\
$1998-2001$ & 43.382 & 28.658 & 12.251 & 2142 & 331 & 0 & 0 \\
$2002-2005$ & 39.169 & 26.675 & 10.698 & 1563 & 233 & 0 & 0 \\
$2006-2009$ & 42.554 & 29.652 & 10.941 & 1700 & 261 & 0 & 0 \\
$2010-2013$ & 40.698 & 29.246 & 9.674 & 1445 & 269 & 39 & 25
\end{tabular}


Año

Total

Estrato 1 Estrato 2 Estrato

Estrato 4 Estrato 5

Estrato 6

2014-2017

28.640

30.610

10.774

1757

359

82

46

Fuente: Elaborado a partir de BAHNVI y MIVAH (2018).

Estos datos son coincidentes en señalar la carencia de acceso a recursos para optar por vivienda de clase media. Aunque el número de casos en el último período 2014-17 aumentó, no es significativo, sin embargo, el tema se visualiza amparado a los lineamientos de política pública de favorecer este sector de la población.

Según la Directriz n. ${ }^{\circ}$ 27-MS-MIVAH-2008, de 5 de marzo del 2008, en el documento Bono colectivo para obras de infraestructura en asentamientos en precarios, programa de erradicación de tugurios, Artículo 2. ${ }^{\circ}$ - La definición de prioridades para la atención a través de la modalidad de bono colectivo, corresponderá otorgarla al Ministerio de Vivienda y Asentamientos Humanos, quien evaluará de acuerdo con el grado de integralidad y multisectorialidad de las intervenciones que se proponga realizar en los asentamientos en condición de precariedad y en condición de tugurio, tanto sus perspectivas de éxito para aliviar la pobreza, así como su efectividad para propiciar la inclusión social MIVAH (2017).

Según los datos del período 2000-17, el propósito para lo que fue destinado el bono, se mantiene la tendencia de beneficiar la construcción en lote propio, seguido de lote y construcción. Un leve incremento en la ampliación, reparación y mejora (RAM), y un leve aumento en bono para una segunda planta. La compra de vivienda existente que mantuvo un porcentaje significativo entre el 2009 y 2012 disminuye al nivel más bajo para el año 2017 (véase figura 2) 
Figura 2. Costa Rica. Bonos pagados por propósito, 2000-2017, datos en porcentajes.

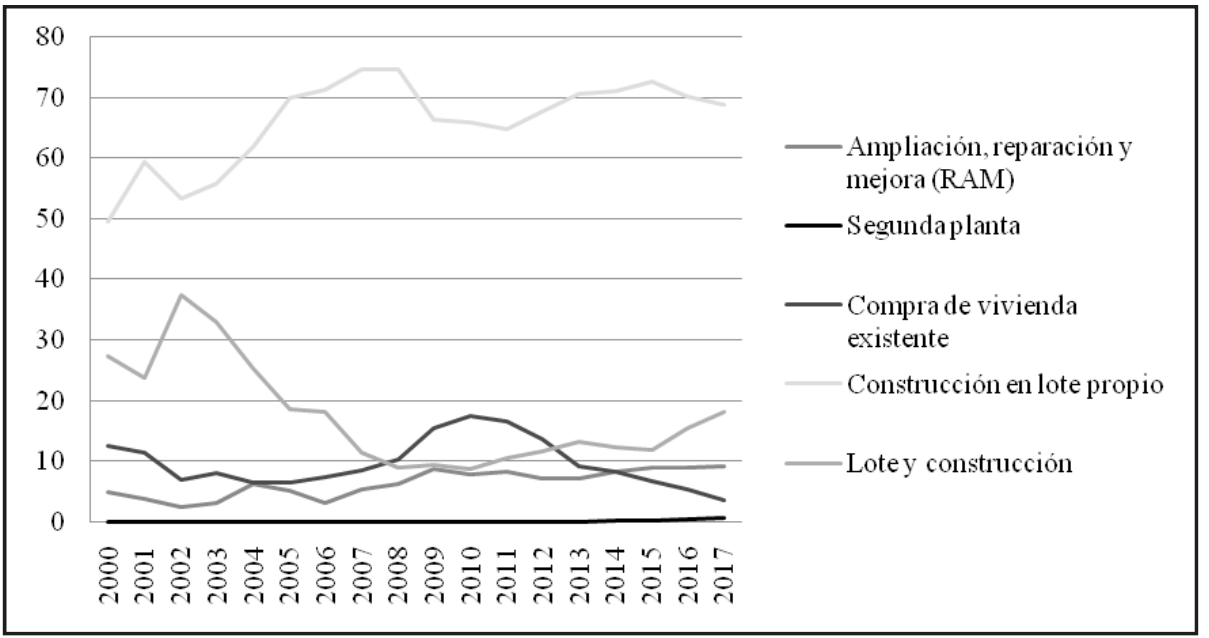

Fuente: Elaborado a partir de BAHNVI (2018).

De acuerdo a la distribución geográfica, los datos 2000-17, indican la mayor distribución de bonos en áreas mixtas, siendo para los años 201617 el valor más alto, un $82,58 \%$ y un $84,87 \%$ respectivamente. Las zonas en transición y periféricas son las que ha mostrado un mayor dinamismo en cuanto a la construcción. En las zonas rurales se muestra un aumento progresivo entre el año 2005-15, en los últimos dos años estos porcentajes tienden a bajar. Las áreas urbanas, muestran un decrecimiento en la distribución de bonos, especialmente entre 2014 y 2017, siendo el porcentaje mayor decrecimiento en el año 2017 (6,00\%). Estos datos evidencian una realidad que debe ser atendida por la recién aprobada Política de Vivienda y Asentamientos Humanos, resalta la necesidad de abordar un crecimiento residencial vertical en las principales centros urbanos; así como atender las necesidades de vivienda de aquellos sectores en pobreza extrema que se ubican en las ciudades, ya sea en condiciones de precario o tugurización. Los intereses particulares de los desarrolladores de proyectos residenciales de bien social, privilegian la ocupación de espacios con servicios básicos, bajos costos de suelo y de construcción en áreas periféricas, sin considerar variables territoriales y ambientales. Deja en evidencia, que en el tema de ordenamiento territorial sigue sin considerarse e n la ocupación de espacio, que para nuestro medio, presenta condiciones de fragilidad ambiental, 
dadas las características hidrometereológicas, tectónicas y de relieve (véase figura 3).

Figura 3: Costa Rica. Bono Familiar de la Vivienda distribuidas por zona geográfica

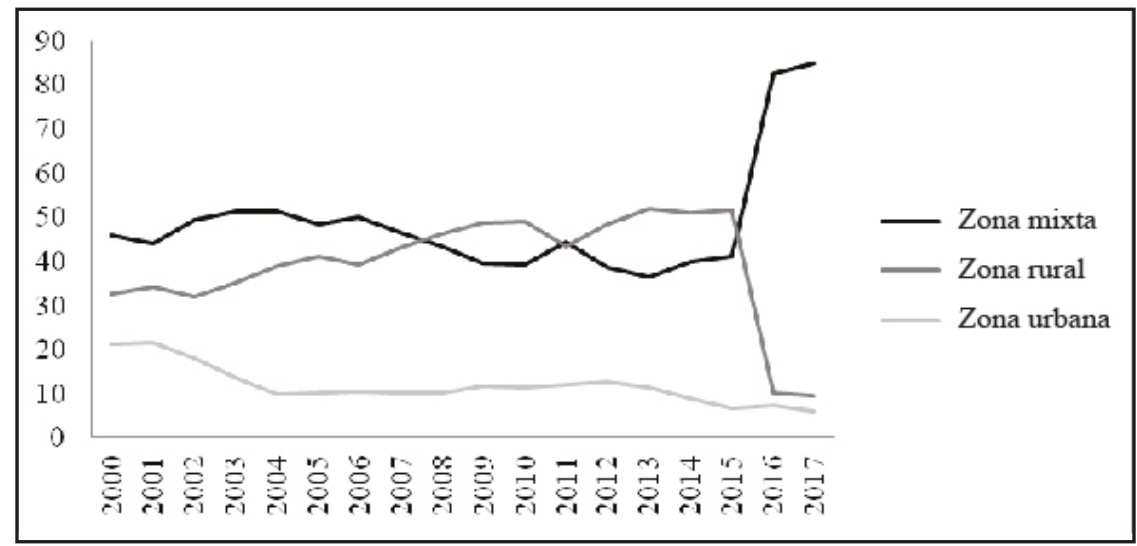

Fuente: Elaborado a partir de BANVHI (2018).

Según región de planificación, la información 2012-17, el Bono Familiar de la Vivienda muestra una distribución creciente en las regiones periféricas, es el caso de la Región Brunca, Huétar Atlántico y Huétar Norte. La Región Central del país mantiene el porcentaje más alto, la información indica un decrecimiento en el período de análisis; aunque es en esta región en la cual el faltante de vivienda es mayor. Este dato corrobora el hecho de que los proyectos de vivienda se ubican en áreas en las cuales el costo del suelo es menor y todavía hay espacio disponible para proyectos residenciales, no así en el área central del país. Esta situación lleva consigo problemas que los municipios posteriormente deben resolver; es común observar en las áreas rurales grandes proyectos residenciales con pobladores externos a la comunidad, escasas fuentes de empleo y desarraigo territorial. Algunos municipios se reúsan a recibir proyectos residenciales de este tipo, dada la problemática socioterritorial que implica. (véase tabla 4). 
Tabla 4: Costa Rica: Bono familiar de la Vivienda distribuido por región de planificación, BANVHI (2018)

\begin{tabular}{|c|c|c|c|c|c|c|c|}
\hline \multirow{2}{*}{$\stackrel{\text { ت्ञ }}{\ddot{\theta}}$} & $\alpha^{\circ}$ & 8 & 8 & 8 & 8 & 8 & 8 \\
\hline & $\dot{\dot{Z}} \stackrel{0}{0}$ & \begin{tabular}{l}
$\delta 3$ \\
\multirow{2}{+}{} \\
$\sigma$
\end{tabular} & ఫ্ & $\underset{\mathscr{D}}{\stackrel{+}{\circ}}$ & $\begin{array}{l}\hat{\circ} \\
\stackrel{0}{0}\end{array}$ & $\stackrel{\widetilde{\infty}}{\stackrel{\infty}{=}}$ & $\stackrel{n}{\Xi}$ \\
\hline \multirow{2}{*}{ 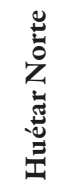 } & $\alpha^{\circ}$ & $\begin{array}{l}\stackrel{0}{ \pm} \\
\text { త }\end{array}$ & $\begin{array}{l}\bar{\infty} \\
\stackrel{0}{n}\end{array}$ & $\stackrel{\partial}{ \pm}$ & $\bar{\sigma}$ & $\hat{\sigma}$ & $\cong$ \\
\hline & $\dot{\dot{z}} \stackrel{0}{0}$ & $\stackrel{\curvearrowright}{\Xi}$ & 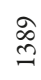 & $\vec{\infty}$ & $\sqrt{\check{n}}$ & $\begin{array}{l}\infty \\
\infty \\
\infty\end{array}$ & $\stackrel{n}{\approx}$ \\
\hline \multirow{2}{*}{ 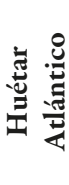 } & $\partial^{\circ}$ & 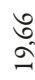 & $\stackrel{\Re}{\stackrel{2}{*}}$ & 孛 & $\widehat{\widehat{S}}$ & సิ & $\begin{array}{l}n \\
\hat{i}\end{array}$ \\
\hline & $\dot{\dot{z}} \stackrel{0}{0}$ & $\stackrel{8}{\circ}$ & $\stackrel{\infty}{\tilde{N}}$ & $\underset{\Xi}{ \pm}$ & ڤ్ & $\stackrel{\infty}{\hat{N}}$ & 文 \\
\hline \multirow{2}{*}{$\underset{\mathscr{E}}{\stackrel{\Xi}{\Xi}}$} & $\partial^{\circ}$ & $\stackrel{\infty}{\stackrel{N}{\Lambda}}$ & 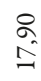 & $\begin{array}{l}\stackrel{+}{2} \\
\stackrel{2}{2}\end{array}$ & 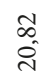 & $\hat{\infty}$ & $\hat{\hat{i}}$ \\
\hline & $\dot{\dot{z}} \stackrel{0}{0}$ & $\hat{\widehat{\sigma}}$ & $\overrightarrow{8}$ & ऽ̊ & $\begin{array}{l}\text { S } \\
\text { ה }\end{array}$ & $\begin{array}{l}\stackrel{2}{\approx} \\
\approx\end{array}$ & $\stackrel{\approx}{\approx}$ \\
\hline \multirow{2}{*}{ 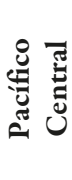 } & $\partial^{\circ}$ & $\underset{f}{F}$ & $\stackrel{n}{*}$ & $\bar{\sim}$ & $\begin{array}{l}\overrightarrow{0} \\
\text { in }\end{array}$ & $\overrightarrow{0}$ & $\stackrel{N}{N}$ \\
\hline & $\dot{\dot{\theta}} \begin{array}{c}0 \\
\tilde{d}\end{array}$ & $\underset{F}{\ni}$ & $\stackrel{\infty}{\ngtr}$ & $\bar{n}$ & $\stackrel{\circ}{6}$ & $\grave{N}$ & గ్రి \\
\hline \multirow{2}{*}{ 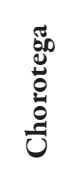 } & $\partial^{\circ}$ & $\stackrel{\infty}{\stackrel{+}{0}}$ & $\stackrel{\infty}{\sim}$ & $\stackrel{\infty}{=}$ & ?2 & $\stackrel{m}{\hat{0}}$ & $\begin{array}{l}\stackrel{0}{\beth} \\
\text { I }\end{array}$ \\
\hline & $\dot{\dot{Z}} \begin{array}{c}0 \\
0 \\
\tilde{J}\end{array}$ & $\widetilde{\sigma}$ & $\tilde{\infty}$ & 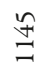 & $\underset{\Xi}{\Xi}$ & $\stackrel{\mathfrak{D}}{\stackrel{J}{ }}$ & $\stackrel{\gtrless}{\approx}$ \\
\hline \multirow{2}{*}{ 节 } & $\alpha^{\circ}$ & $\begin{array}{l}N \\
\text { ñ }\end{array}$ & $\begin{array}{l}\stackrel{b}{\leftrightarrows} \\
\stackrel{+}{m}\end{array}$ & $\stackrel{b}{m}$ & ثे & $\begin{array}{l}\approx \\
\approx\end{array}$ & $\stackrel{ \pm}{\tilde{d}}$ \\
\hline & $\dot{\dot{z}} \begin{array}{c}0 \\
0\end{array}$ & $\begin{array}{l}\infty \\
\text { m } \\
m\end{array}$ & $\stackrel{\hat{m}}{\tilde{m}}$ & $\overrightarrow{\widetilde{n}}$ & ָั & $\hat{s}$ & $\begin{array}{l}\vec{\infty} \\
\stackrel{\sim}{\approx}\end{array}$ \\
\hline 紊 & & 곡 & 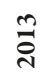 & 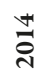 & $\stackrel{n}{\tilde{N}}$ & ᄅั & $\stackrel{\text { อ }}{\circ}$ \\
\hline
\end{tabular}

Fuente: Elaborado a partir de BANVHI (2018). 
La puesta en práctica de la Ley de Atención a Mujeres en Condición de Pobreza, Ley n. 7.769 , del 24 de abril de 1998, la cual promueve mejoramiento en las condiciones de vida de las mujeres, mediante un proceso de formación integral que contempla el acceso a vivienda digna, se expresa en los datos aportados por el BANVHI, especialmente a partir del año 2000, con un aumento paulatino hasta alcanzar los mayores porcentajes en los dos últimos años, 2016 con un 58,20 y 2017 con un 60,13 de los bonos otorgados a las mujeres jefas de hogar (véase gigura 4).

Figura 4. Costa Rica. Bono familiar de la Vivienda distribuido por género de jefatura de la familia

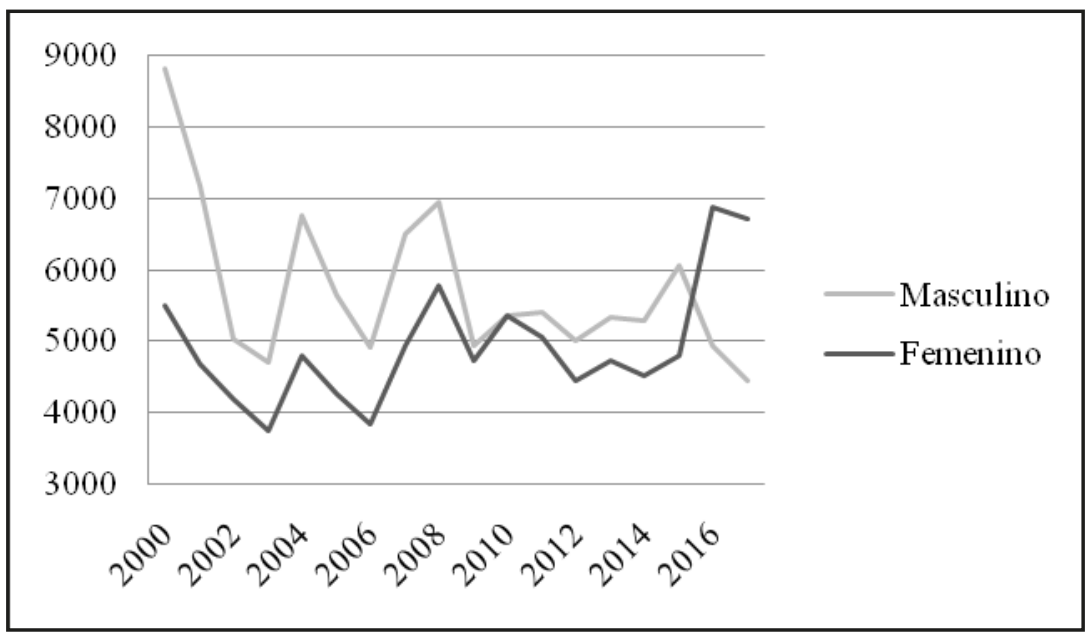

Fuente: Elaborado a partir de BANVHI (2018).

De acuerdo a los datos aportados por el BANVHI (2018), el bono familiar de la vivienda bajo la modalidad regular, es el mayor porcentaje del destino del presupuesto; sin embargo, inicia un descenso paulatino a partir del 2000, año en que se destinó un 87,2\% del presupuesto, para obtener los porcentajes más bajo en el año 2013 con un 54,99\% y en el año 2017 con un $55,84 \%$. Mientras que otras modalidades incrementan sus porcentajes de participación (véase tabla 5). 
Tabla 5: Costa Rica: Bono familiar de la Vivienda según modalidad de presupuesto, BANVHI (2018). Datos en porcentajes

\begin{tabular}{|c|c|c|c|c|c|c|c|c|c|}
\hline & 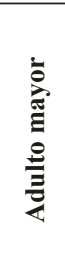 & 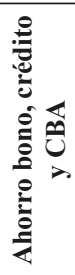 & 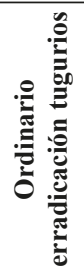 & 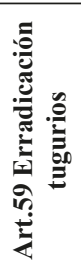 & 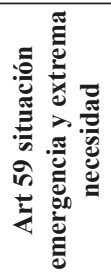 & 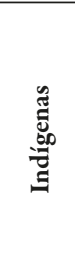 & 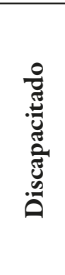 & $\underset{\mathscr{Z}}{\stackrel{\vec{Z}}{\vec{Z}}}$ & 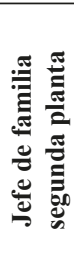 \\
\hline 2000 & 0,0 & 0,0 & 5,9 & - & 8,8 & 0,0 & 2,6 & 82,7 & - \\
\hline 2001 & 0,4 & 0,7 & 6,1 & - & 5,7 & 0,0 & 4,1 & 83,0 & - \\
\hline 2002 & 0,7 & 1,1 & 15,4 & - & 19,2 & 0,0 & 4,6 & 58,9 & - \\
\hline 2003 & 0,7 & 7,1 & 19,2 & - & 4,9 & 0,0 & 6,5 & 61,7 & - \\
\hline 2004 & 1,1 & 7,6 & 10,8 & - & 6,6 & 0,0 & 7,2 & 66,8 & - \\
\hline 2005 & 1,6 & 4,0 & 4,5 & - & 9,0 & 0,5 & 7,6 & 72,7 & - \\
\hline 2006 & 1,7 & 6,9 & 1,7 & - & 11,1 & 3,1 & 6,7 & 68,7 & - \\
\hline 2007 & 1,3 & 4,7 & 1,6 & - & 4,1 & 4,9 & 5,2 & 78,2 & - \\
\hline 2008 & 1,0 & 3,3 & 1,4 & - & 9,3 & 8,8 & 4,4 & 71,7 & - \\
\hline 2009 & 2,2 & 1,0 & 1,0 & - & 17,6 & 7,5 & 4,3 & 66,4 & - \\
\hline 2010 & 3,02 & 0,71 & - & 1,62 & 19,41 & 10,35 & 3,59 & 61,29 & - \\
\hline 2011 & 2,68 & 0,42 & - & 4,79 & 18,98 & 5,90 & 3,10 & 64,14 & - \\
\hline 2012 & 2,42 & 0,83 & 17,64 & - & 18,62 & 8,37 & - & 49,19 & - \\
\hline 2013 & 3,20 & 0,56 & 16,55 & - & 15,42 & 6,44 & 2,84 & 54,99 & - \\
\hline 2014 & 3,92 & 0,61 & 19,90 & & 12,07 & 3,19 & 3,59 & 58,69 & 0,03 \\
\hline 2015 & 3,75 & 1,08 & 16,93 & - & 10,23 & 3,77 & 3,15 & 61.05 & 0,05 \\
\hline 2016 & 4,66 & 3,44 & 15,67 & 1,41 & 11,66 & 2,70 & 3,49 & 59,96 & - \\
\hline 2017 & 5,24 & 2,68 & 16,01 & 0,67 & 14,83 & 1,90 & 2,83 & 55,84 & - \\
\hline
\end{tabular}

Fuente: Elaborado a partir de BANVHI (2018).

Con respecto a la entrega de bono familiar de la vivienda según modalidad de presupuesto, la aprobación de la Ley Integral para la Persona Adulta Mayor, Ley n. ${ }^{\circ}$ 7.935, del 25 de octubre de 1999 , la cual promulga que el adulto mayor tiene derecho a una vivienda digna, apta para sus necesidades, y que le garantice habitar en entornos seguros y adaptables; se manifiesta en los indicadores de vivienda especialmente a partir del año 2004, con un aumento progresivo hasta lograr su mayor porcentaje en el año 2017, otorgando un 5,24\% de los bonos mediante este presupuesto. Sobresale los bonos otorgados bajo la modificación 
al Art. 59 situación emergencia y extrema necesidad, que se incrementa especialmente del 2009 al 2013, para registrar valores más bajos en los últimos años.

La población indígena, a pesar de que la Ley de Inscripción y Cedulación Indígena de Costa Rica, Ley n. ${ }^{\circ}$ 7.225, del 19 de abril de 1991, otorga a la población indígena inscribirse y obtener estatus como costarricenses por nacimiento, con los mismos deberes y derechos; el bono familiar de la vivienda fue otorgado hasta el año 2005 en que solamente 0,05\% del presupuesto se destina a dotar de vivienda social a este grupo; alcanzando los porcentajes más altos en el año 2008 y 2010. Sin embargo, según observaciones y visitas de campo, las soluciones habitacionales otorgadas no corresponde con el entorno y las tradiciones culturales de este grupo de población.

\section{Consideraciones finales}

- Esfuerzos importantes en la política pública para promover la integración de la vivienda con el ordenamiento territorial y asentamientos humanos, expresos en las recientes políticas aprobadas. Así como acciones por agrupar en una temática las instituciones de toma de decisiones para el sector vivienda, es el caso del Ministerio de Vivienda y Asentamientos Humanos. El tema vivienda de bien social, poseen una amplia normativa en y un sistema financiero estratificado en bonos individuales y colectivos, que propone atender los grupos de población de menores ingresos económicos.

- En cuanto al tema de ordenamiento territorial y la disponibilidad de tierras para desarrollo residencial; se evidencia un agotamiento de los terrenos con aptitud residencial, crece el precio de la tierra y lo proyectos inmobiliarios continúan siendo de baja densidad. Falta de integración física del sistema de ciudades, tanto en el país como en la Gran Área Metropolitana, por las deficiencias en su sistema de transportes.

- La carencia o desactualización de los planes reguladores limitan la capacidad de planificación territorial. Esto propicia la ausencia de regulación de uso del suelo, donde se establezcan lo sitios apropiados para desarrollar proyectos de vivienda de interés social. Municipios 
con restricciones específicas como densidad, la no existencia de uso residencial, y muchas veces no desean que en sus territorios se desarrollen proyectos dirigidos a este tipo de población. Asimismo, problemas por la ocupación de zonas vulnerables a amenazas naturales, zonas ambientalmente vulnerables o de suelos muy fértiles. Las principales ciudades intermedias del país están creciendo y replicando las problemáticas que hoy se sufren en la GAM.

- Se ha propiciado un modelo de urbanizaciones para todos los estratos sociales, y condominios para las clases altas. Los condominios ocupan un porcentaje bajo en los datos de construcción y benefician a un sector de población de clase alta que busca seguridad, lujo y comodidad; que además se aisla del resto de la comunidad. Por otro lado, se mantiene el modelo de crecimiento urbano horizontal para una gran cantidad de población, con las tendencias inmobiliarias de viviendas alejadas de la ciudad propician la perdida en la calidad del hábitat. Desaprovechando el potencial de servicios y centralidades que ofrecen las áreas urbanas bajo el concepto de "Centralidades Densas Integrales”, propiciando la degradación de los recursos naturales.

- Se deja en manos de desarrolladores las decisiones que determinan el tipo de oferta disponible en el mercado (tipología de la vivienda) y el lugar donde será satisfecha la demanda por viviendas. Esto ha propiciado un aumento progresivo del bono de vivienda en áreas rurales y zonas en transición urbano-rural. Las regiones de planificación con mayor dotación de vivienda social, no necesariamente son las que poseen mayor déficit cuantitativo de vivienda.

- Se tiene un sector de la clase media que se incorpora recientemente como una prioridad de atención, dado que no tiene acceso a la vivienda, tanto como por la disponibilidad de recursos como la oferta inmobiliaria disponible. 


\section{Referencias}

BANVHI. "Características de la vivienda financiada con bono familiar". Unidad de Comunicaciones. San José, Costa Rica, 2016.

.El Bono Familiar de Vivienda". Unidad de Comunicaciones. San José, Costa Rica, 2018.

CALDERÓN, G. "Gobernanza en el análisis del bienestar social". Revista Geográfica de América Central, v. 58, pp. 45-69, 2017.

EL PRESIDENTE DE LA REPÚBLICA, la Ministra de Salud y el Ministro de Vivienda y Asentamientos Humanos. Directriz n. ${ }^{\circ} 27$. San José, Costa Rica, 2013.

ESPINOZA, J. C. "Características de la vivienda y acceso para los grupos pobres y la clase media: 2010-2013”. En Informe Estado de la Nación en Desarrollo Humano Sostenible 2013. San José, Costa Rica, 2013.

FUPROVI - Fundación Promotora de Vivienda. "Aportes para un programa de vivienda". San José, Costa Rica, 2013.

. "Situación de la Vivienda y Desarrollo Urbano en Costa Rica 2015”. San José, Costa Rica, 2015.

. "Situación de la Vivienda y Desarrollo Urbano en Costa Rica 2015”. San José, Costa Rica, 2016.

. "Entorno del Sector Vivienda, Construcción y Urbanismo". I Balance 2017. San José, Costa Rica, 2017.

GOBIERNO DE COSTA RICA. “Ley n. ${ }^{\circ} 190$. Crea Cooperativa denominada "Casas Baratas La Familia”. Publicada en el Diario Oficial La Gaceta, del 14 de agosto de 1942.

."Ley n. ${ }^{\circ} 148$ ”. Crea Departamento de la Habitación de la Caja Costarricense de Seguro Social (CCSS) para Vivienda Popular. Aprobada el 8 de agosto de 1945.

. "Ley n. ${ }^{\circ}$ 680. Ley del inquilinato. Aprobada el 3 de setiembre de 1946. 
. “Ley n. ${ }^{\circ} 1.788$ ”. Ley Orgánica del Instituto Nacional de Vivienda y Urbanismo INVU. Aprobada el 24 de agosto de 1954.

. “Ley n. ${ }^{\circ}$ 2.760”. Ley de Erradicación de Tugurios y Defensa de sus Arrendatarios. Aprobada el 16 de junio de 1961.

. "Ley n. ${ }^{\circ} 4.240$ ”. Ley de Planificación Urbana. Publicada en el Diario Oficial La Gaceta, 274,del 31 de noviembre de 1968.

. “Ley n. ${ }^{\circ}$ 6.999”. Ley del Impuesto sobre Traspasos de Bienes Inmuebles. Publicada en el Diario Oficial La Gaceta, del 3 de septiembre de 1985.

. "Ley n. ${ }^{\circ}$ 7.052". Ley del Sistema Financiero Nacional para la Vivienda y Creación del BANHVI (Banco Hipotecario de la Vivienda). Publicada en el Diario Oficial La Gaceta, de 13 de noviembre de 1986.

. "Ley n. 7.225”. Ley de Inscripción y Cedulación Indígena de Costa Rica. Publicada en el Diario Oficial La Gaceta, 86, del 08 de mayo de 1991.

."Ley n. ${ }^{\circ} 7.769$ ”, del 24 de abril de 1998. Atención a las mujeres en condiciones de pobreza. San José, Costa Rica. Publicada en el Diario Oficial La Gaceta, 96, del 20 de mayo de 1998.

. "Ley n. ${ }^{\circ}$ 7.935”. Ley Integral para la Persona Adulta Mayor. Publicada en el Diario Oficial La Gaceta, 221, del 25 de octubre 1999.

. “Ley n. ${ }^{\circ} 8.261$ ”. Ley General de la Persona Joven. San José, Costa Rica. Publicada en el Diario Oficial La Gaceta, 95, del 20 de mayo 2002.

. “Ley n. ${ }^{\circ}$ 8.627”. Ley de Presupuesto Ordinario y Extraordinario de la República. Publicada en el Diario Oficial La Gaceta, 251, del 31 de diciembre de 2007.

. "Ley n. ${ }^{\circ}$ 8.680". Ley Especial para Titulación de Vivienda en Precarios y en Zonas de Desarrollo Urbano no Reconocidas (precarios). Publicada en el Diario Oficial La Gaceta, del 12 de noviembre de 2008.

. "Ley n. ${ }^{\circ}$ 8.683". Ley sobre el Impuesto Solidario para el Fortalecimiento de Programas de Vivienda. Publicada en el Diario Oficial La Gaceta, del 19 de noviembre de 2008. 
."Ley n. ${ }^{\circ}$ 8.936”. Ley del Sistema Financiero Nacional para la Vivienda y Creación del BANHVI. Publicada en el Diario Oficial La Gaceta del 21 de junio del 2011.

. "Ley n..$^{\circ}$ 8.960". Ley de Modernización de los mecanismos para el desarrollo de vivienda de clase media mediante la reforma del artículo 5 de la Ley 1788, Ley Orgánica del Instituto Nacional de Vivienda y Urbanismo. Aprobado el 05 de julio del 2011.

."Ley n..$^{\circ}$ 8.957". Creación de un bono para segunda vivienda familiar que autoriza el subsidio del bono familiar en primera y segunda edificación. Publicada en el Diario Oficial La Gaceta n. ${ }^{\circ}$ 167, del 31 de agosto del 2011.

. “Ley n. 9.157”. Ley de Creación del Fondo para el Financiamiento de Viviendas de Primera Solución para la Clase Media. Aprobado el 01 de octubre 2013.

. Plan Nacional de Desarrollo 2015-2018 “Alberto Cañas Escalante”. San José, Costa Rica, 2014.

INEC - Instituto Nacional de Estadísticas y Censos. “Censo 2011”. San José, Costa Rica, 2011.

. “Encuesta Nacional de Hogares (ENAHO)”. San José, Costa Rica, 2017.

INVU - Instituto Nacional de Vivienda y Urbanismo. "Reglamento de Renovación Urbana”. San José, Costa Rica, 2017.

. "Manual de Planes Reguladores como Instrumento De Ordenamiento Territorial”. Publicado en Gaceta Oficial. San José, Costa Rica, 31 enero 2018.

"Las lecciones de Hábitat III: Los retos globales en materia urbana y de asentamientos humanos son atinentes al país”. La Nación, 10 noviembre 2016.

MATA, C. "Efecto real y potencial del FODESAF en el combate a la pobreza". En Informe Estado de la Nación en Desarrollo Humano Sostenible, San José, Costa Rica, 2014.

y TREJOS, J. "El gasto o inversión social pública continúan su expansión en el 2016 pese al desequilibrio fiscal”. En Informe Estado de la Nación en Desarrollo Humano Sostenible, San José, Costa Rica, 2017. 
MIVAH - Ministerio de Vivienda y Asentamientos Humanos. "Estrato Socio Económico Medio: Análisis de tendencias en materia de vivienda, y una propuesta de lineamientos para su atención”. San José, Costa Rica, 2012.

. Sector Vivienda y Asentamientos Humanos. "Compendio Estadístico de Vivienda”. San José, Costa Rica, 2014.

. "Política Nacional de Vivienda y Asentamientos Humanos 2013 a 2030 y su Plan de Acción”. Decreto de oficialización y documento completo. San José, Costa Rica, 2014.

- Gobierno de la República de Costa Rica. Informe Nacional Hábitat III. Presentado en la Tercera Conferencia de las Naciones Unidas acerca de la Vivienda y el Desarrollo Urbano Sostenible, en Quito-Ecuador, 17-20 de octubre, 2016. San José, Costa Rica, 2016.

. "Competencias MIVAH Documento preparado por la Asesoría Jurídica”. San José, Costa Rica, 2017.

MP-MIVAH. Reglamento de la Ley Especial para Titulación de Vivienda en Precarios y en Zonas de Desarrollo Urbano No Reconocidas (Precarios). San José, Costa Rica, 2008.

SALINAS, L., y PARDO, Ana. M. “Urbanismo neoliberal en la expansión de las ciudades”. Bitácora, v. 28, n. 1, pp. 117-23.

SECRETARÍA EJECUTIVA DEL CONSEJO MONETARIO CENTROAMERICANO. Colección de Leyes Regionales. Ley del Sistema Financiero Nacional para la Vivienda y Creación del BANHVI (Banco Hipotecario De La Vivienda).Ley n. ${ }^{\circ}$ 7.052, de 13 de noviembre de 1986 y sus reformas). San José, Costa Rica, 1986.

\section{Direcciones electrónicas:}

Banco Hipotecario de la Vivienda (BANVHI) http://www.banhvi.fi.cr/publicaciones/estadisticas.aspx

Colegio Federado de Ingenieros y Arquitectos (CFIA) 
196 Estudos territoriais no Brasil e na Costa Rica

http://www.cfia.or.cr/estadisticasCons.html. Estadísticas de la Cons trucción: 2017

Instituto Nacional de Estadísticas y Censos (INEC)

http://www.inec.go.cr/vivienda

Instituto Nacional de Vivienda y Urbanismo

http://www.invu.go.cr/vivienda/index.html

Fundación Promotora de Vivienda (FUPROVI)

http://www.fuprovi.org/investigaciones

Ministerio de Vivienda y Asentamientos Humanos (MIVAH)

https://www.mivah.go.cr/Biblioteca_Estadisticas.shtml 


\title{
8. Planes de sostenibilidad turística para el turismo rural comunitario de Costa Rica: metodologia para su elaboración
}

\author{
Meylin Alvarado Sánchez \\ Pablo Miranda Álvarez
}

\section{Introducción}

Ante los procesos de transformación de la actividad turística desde la década de 1980 con el desarrollo del turismo sostenible, Costa Rica como destino turístico de naturaleza ha estructurado una serie de propuestas por parte del Instituto Costarricense de Turismo (ICT), Universidades públicas y Organizaciones no gubernamentales que han tenido como fin el fortalecimiento de la actividad turística desde la perspectiva del desarrollo sostenible. Definido desde las décadas de 1960 y 1970 a partir del modelo clásico de desarrollo económico, iniciando un proceso que expone las preocupación por los temas ambientales y especialmente en los impactos generados por el modelo clásico de desarrollo y se inicia la búsqueda de nuevas formas de analizar el mismo.

En 1987 a partir del informe Brundtland elaborado por una comisión dirigida por la Organización de las Naciones Unidas (ONU) se utiliza por primera vez el concepto de desarrollo sostenible definiéndolo como "aquel que garantiza la satisfacción de las necesidades del presente sin comprometer las posibilidades de las generaciones futuras para satisfacer sus propias necesidades" (Rainforest Alliance, 2009, p. 5). Lo que implica que las propuestas que contemplen este tipo de desarrollo, deben incorporar además de la dimensión económica, las otras dimensiones de la sostenibilidad, como son la ambiental, social y cultural, contemplando acciones y compromisos para mejorarlas logrando un equilibrio entre estas en el tiempo y en el espacio, donde predomine 
el valor de la ética, el empoderamiento y la concientización de todos los actores del desarrollo.

Derivado de este concepto, la Organización Mundial del Turismo ${ }^{1}$ (OMT) definió al turismo sostenible como aquel que "satisface las necesidades presentes de los turistas y de las regiones donde se lleva a cabo el turismo, a la vez que protege y mejora las oportunidades para el futuro" (Rainforest Alliance, 2009). Siguiendo los tres pilares del desarrollo sostenible se crean los Criterios Globales del Turismo Sostenible con el fin de consensuar los principios mínimos de sostenibilidad organizados en cuatro temas principales: planificación eficaz para la sostenibilidad, maximización de los beneficios sociales y económicos de las comunidades locales, mejoramiento del patrimonio cultural y la reducción de los impactos negativos sobre el ambiente (Rainforest Alliance, 2008).

Basados en esta concepción de desarrollo, la actividad turística ha adoptado una serie de buenas prácticas a nivel nacional e internacional que permiten acercarse al cumplimiento de los objetivos propuestos en la Agenda 21 para la Industria de los viajes y el turismo de la Organización Mundial del Turismo (OMT) y el World Travel and Tourism Council (OMT, 1999). Existen diversas guías para aplicar estas prácticas y que dan diferentes definiciones, para las mismas, a nivel latinoamericano se pueden mencionar las siguientes:

La Guía de Buenas Prácticas de la Cámara Oficial de Comercio e Industria de Guadalajara, México (2004), indica que estas guías pretenden concientizar sobre la importancia del papel potencial que pueden desempeñar estos negocios en el desarrollo sostenible de las comunidades, mediante prácticas cotidianas ambientalmente responsables, cuyo objetivo principal es la adopción de una serie de medidas que disminuyan el impacto de la actividad turística en las diferentes dimensiones de la sostenibilidad.

También, la Guía de Gestión Sostenible para Hoteles en Crecimiento (2009) de la Asociación de Pequeños Hoteles de Costa Rica (APHCR) se refiere a estas prácticas, como medidas sencillas, que se llevan a cabo para minimizar el impacto negativo sobre el ambiente natural y cultural y que además estas traen beneficios económicos para las empresas, porque reducen los costos de operación de las mismas.

Basado en la Conferencia de Río de Janeiro, de un documento denominado Agenda 21. Desarrollo y Medio Ambiente. 
Por su parte, la Guía de Buenas Prácticas de Turismo Sostenible para Comunidades de Latinoamérica, de Raintforest Alliance (2009, p. 9), da una definición más amplia de estas prácticas y las relaciona con las iniciativas de turismo y las comunidades:

Acciones para prevenir, corregir y/o mejorar ciertos aspectos de la operación turística. Éstas se pueden implementar en todas las áreas de servicio y operación de las empresas. Su adopción y aplicación beneficiará ambiental, sociocultural y económicamente al emprendimiento y a la comunidad. Las buenas prácticas deben garantizar que se produce el menor impacto posible sobre los recursos, que se mejora la calidad del producto turístico, que mejora la imagen de la empresa frente al cliente, que la gestión empresarial es más eficiente y que se consigue un mejor desempeño socioeconómico.

Asimismo existen diferentes normas a nivel internacional, que certifican la aplicación de estas prácticas, en el caso de Costa Rica se encuentra la Norma Certificado de Sostenibilidad Turística (CST) del Instituto Costarricense de Turismo (ICT) establecida por Decreto Ejecutivo en mayo de 1998 y la cual tiene como fin certificar la sostenibilidad, ${ }^{2}$ de las empresas de hospedaje, parques temáticos sostenibles, empresas gastronómicas sostenibles, tour operadores marítimos costeros y tour operadores y empresas rentadoras de vehículos, en el cumplimiento de una serie de medidas, las cuales permiten generar una adecuada interacción entre la oferta, la demanda y la comunidad.

De acuerdo con el ICT (2017) para el año 2016, Costa Rica ya contaba con 246 empresas turísticas, con la certificación CST, de las cuales un 22,8 \% (105 empresas) se ubicaban en los niveles 1 y 2 de sostenibilidad, lo que para la institución significa una etapa importante, que demuestra que estas empresas han emprendido esfuerzos en busca de mejorar su accionar en el marco de una política de sostenibilidad. Mientras que un 78,1\%, estaban en los niveles 3, 4 y 5 , predominado el nivel 4 , con un $24 \%$ del total, un dato muy positivo, que evidencia un trabajo constante por parte de los empresarios en cuanto a sostenibilidad, protección y recuperación de los recursos naturales y culturales,

\footnotetext{
Los niveles de sostenibilidad van de 1 a 5 y se representan por medio de una hoja verde, que representa la sostenibilidad.
} 
aporte en temas de carácter social y un firme rescate de elementos gastronómicos y artísticos locales, además de la inclusión de los visitantes en estos procesos.

La siguiente tabla muestra estos datos, de acuerdo al tipo de empresa turística y el nivel de sostenibilidad de cada una. Donde también muestra que la mayor cantidad de empresas con CST, son las de Hospedaje (66\%) seguida por las Tours Operadoras con un 23\%, esto debido a que en el inició de esta norma de certificación (1998), la misma estaba dirigida únicamente a estos dos tipos de empresas, que por los proceso de recertificación y del trabajo constante de los empresarios, se ha facilitado que estas hayan permanecido en el tiempo con la certificación y hoy sean mayoría.

Tabla 1: Cantidad de empresas con el CST en Costa Rica, para el año 2016

\begin{tabular}{|l|c|c|c|c|c|c|}
\hline \multirow{2}{*}{ EMPRESAS } & \multicolumn{6}{|c|}{ NIVELES DE SOSTENIBILIDAD TURISTICA CST } \\
\cline { 2 - 8 } & Nivel 1 & Nivel 2 & Nivel 3 & Nivel 4 & Nivel 5 & TOTAL \\
\hline Hospedaje & 21 & 59 & 61 & 39 & 54 & 234 \\
\hline Tour Operadoras & 8 & 7 & 15 & 31 & 21 & 82 \\
\hline Rentadoras de Vehículos & 0 & 0 & 2 & 3 & 2 & 7 \\
\hline Parques Temáticos & 1 & 2 & 2 & 5 & 2 & 12 \\
\hline Gastronómicas Sostenibles & 1 & 0 & 1 & 4 & 0 & 6 \\
\hline $\begin{array}{l}\text { Tour Operadoras Marino } \\
\text { Costero }\end{array}$ & 2 & 4 & 1 & 2 & 1 & 10 \\
\hline \multicolumn{1}{|c|}{ TOTAL } & 33 & 72 & 82 & 84 & 80 & 351 \\
\hline
\end{tabular}

Fuente: ICT (2017).

Para otorgar esta certificación, a dichas empresas, se les evalúa el cumplimiento de una serie buenas prácticas de sostenibilidad turística, basada en cuatro ámbitos: entorno físico biológico, planta de servicio, cliente externo y socioeconómico, los cuales permiten generar una mejor interacción entre la oferta y la comunidad dando como resultado el desarrollo sostenible en beneficio de la población local y los visitantes, además de ser más competitivos en el mercado nacional e internacional. Guereña (2006) indica que el término buenas prácticas, se refiere a las medidas de corrección que se implementan en las empresas turísticas, con la finalidad de reducir los impactos de la operación de su actividad y así mejorar la calidad del producto turístico ofrecido. 
A partir de este enfoque integral del turismo y de la participación de las organizaciones comunitarias, en temas de conservación ambiental que posteriormente las llevaron a desarrollar actividades turísticas, es que surge el Turismo Rural Comunitario (TRC), el cual implica una participación activa de la población local, mediante grupos organizados que al mismo tiempo desempeñan acciones de protección y educación ambiental, para la preservación de recursos tanto naturales como culturales. En Costa Rica este tipo de turismo surge desde inicios de los años 90s, como una alternativa económica de las organizaciones comunitarias que se dedicaban a la conservación.

Por las incidencias de estas organizaciones, en el año 2009, la Asamblea Legislativa de Costa Rica aprobó el proyecto de Ley del Fomento del Turismo Rural Comunitario (Ley n. ${ }^{\circ}$ 8.724), que define este tipo de turismo como: "Experiencias turísticas planificadas e integradas sosteniblemente al medio rural y desarrolladas por los pobladores locales organizados para beneficio de la comunidad" y menciona que todas las actividades de este tipo de turismo deben estar basado en la Sostenibilidad, esto implica objetivos de competitividad económica, equidad social y sostenibilidad ambiental, así como la gobernabilidad política, con acciones de largo plazo, que colocan a los miembros de la comunidad como actores principales del desarrollo local, generando un crecimiento económico con equidad social, además de la transformación de los métodos de producción y de los patrones de consumo que se sustenten en el equilibrio ecológico, lo que implica el respeto a la diversidad étnica y cultural.

Por su parte el ICT (2017) en su Plan Nacional de Desarrollo Turístico 2017-21, plantea que la sostenibilidad en Costa Rica, históricamente ha tomado en cuenta los siguientes aspectos: dar un uso óptimo a los recursos medioambientales, respetar la autenticidad sociocultural de las comunidades locales, asegurar una actividad económica viable a largo plazo e impulsar practicas turísticas sostenibles en los visitantes, como una experiencia turística. Por lo tanto todos estos, se han incluido como parte de la política turística del país, que tiene como uno de sus objetivos, "impulsar la adopción de prácticas innovadoras para promover el uso eficiente de los recursos turísticos en beneficio de los turistas, las empresas y la población” (ICT, 2017, p. 77).

Basado en lo anterior, el Programa de Estudios Turísticos Territoriales (PETT) de la escuela de Ciencias Geográficas de la Universidad Nacional de Costa Rica (UNA) a través de sus proyectos de extensión universitaria, con fondos FUNDER 2012 y fondos CONARE 2016, como aporte al 
desarrollo comunitario, ha desarrollado una metodología de capacitación y acompañamiento para las organizaciones e iniciativas comunitarias, que les permitan el diseño e implementación de estas prácticas de sostenibilidad turística, que contempla tres áreas fundamentales: la participación de las comunidades locales, la gestión del territorio (recursos naturales y culturales) y la viabilidad económica, que se reflejan en el diseño del plan de sostenibilidad turística de cada una de ellas.

\section{Resultados}

La metodología para el diseño de planes de sostenibilidad turística, desarrollada por el PETT, se ha implementado de forma participativa a través de sus proyectos de extensión universitaria, en iniciativas de TRC, que cuentan con un producto turístico previamente diseñado, ubicadas en diferentes regiones del país, tales como el Golfo y Península de Nicoya, en las provincias de Puntarenas y Guanacaste y en la cuenca media del río Pacuare, en la provincia de Cartago. Con esta se pretende que las organizaciones cumplan con los lineamientos establecidos por la Ley n. ${ }^{\circ}$ 8.724, Ley del Fomento del Turismo Rural Comunitario y de la Norma del CST del ICT, basado en una serie de acciones que se denominan buenas prácticas de sostenibilidad turística Para el diseño de estos planes de sostenibilidad, el PETT, propone las siguientes seis fases:

Inserción en la comunidad: En los proyectos de extensión la primera actividad a realizar, es la inserción en la comunidad, para lo que se realizan visitas de campo y reuniones con líderes comunales, para dar a conocer la metodología y validar su aplicación, además para conocer cada una de las iniciativas de TRC que están operan en cada comunidad.

Inducción: Consta de talleres de capacitación en cada comunidad, sobre la implementación de buenas prácticas de sostenibilidad en turismo, basadas en la norma del CST del ICT, que les permita a los líderes y a la comunidad en general conocer: qué son estas prácticas, cuáles son los beneficios al aplicarlas, por medio de charlas, videos y se hace trabajo de campo de manera interioricen de forma integral los conceptos y las prácticas. Además en esta etapa se define el cronograma de actividades, para las siguientes etapas. 
Evaluación: Una vez que las organizaciones ya conocen sobre las buenas prácticas, se realiza una evaluación de sostenibilidad turística, que involucra trabajo campo, entrevistas a los encargados de las iniciativas, y la evaluación, utilizando para ello el instrumento de evaluación que se presenta en el Anexo 1 , con el fin de obtener un diagnóstico de cada iniciativa, para identificar las fortalezas y debilidades en temas de sostenibilidad de estas, como base para el posterior diseño de evidencias, específicamente en el tema área de capacitaciones.

Acompañamiento en la creación de evidencias de sostenibilidad turística: En esta fase se apoya a los actores en la creación y recolección de evidencias, de acuerdo al diagnóstico obtenido en la etapa anterior, estas se basan en los entornos de sostenibilidad: ambiental, cliente externo, socioeconómico y cultural. Además se determinan las actividades que deben realizar para la construcción de las mismas y los responsables de llevar a cabo estas actividades.

La tabla 2, presenta uno de los resultados de evidencias de sostenibilidad turística de forma general, propuestas de forma participativas, por los líderes de las comunidades metas del PETT.

Tabla 2: Lista de evidencias de evidencia de sostenibilidad turística a elaborar con los oferentes de las comunidades metas del PETT

\begin{tabular}{|c|c|}
\hline EVIDENCIAS & TIPO \\
\hline Bitácoras & $\begin{array}{l}\text { Bitácoras de monitoreo impactos, de limpieza, de control mantenimiento, } \\
\text { de Vida Útil Equipos, de reparaciones de equipo, control de reducciones. }\end{array}$ \\
\hline $\begin{array}{c}\text { Manuales con } \\
\text { protocolos y códigos } \\
\text { de éticas }\end{array}$ & $\begin{array}{l}\text { Manual de Empleados, Manual de Servicios al cliente, Manual de } \\
\text { Proveedores, Manual de Socios, Manual de Seguridad }\end{array}$ \\
\hline Cartillas & $\begin{array}{c}\text { Cartilla informativa a huéspedes, Cartilla informativa a empleados, } \\
\text { Cartilla Informativa Tours, Cartilla de menús }\end{array}$ \\
\hline Registros & $\begin{array}{l}\text { Registros de Visitantes, de compras y facturas, Registros evaluaciones, de } \\
\text { capacitaciones, de convenios, }\end{array}$ \\
\hline $\begin{array}{l}\text { Convenios y } \\
\text { certificaciones }\end{array}$ & $\begin{array}{l}\text { Certificación y convenio con instituciones públicas, con instituciones } \\
\text { privada, certificación y convenio con organizaciones, certificación y } \\
\text { convenio con oferta local }\end{array}$ \\
\hline Autoevaluaciones & $\begin{array}{c}\text { De Calidad del Producto y/o Servicio de acuerdo a Estándares Nacionales } \\
\text { e Internacionales (ICT, OEA, PNUD) }\end{array}$ \\
\hline $\begin{array}{l}\text { Estudios de } \\
\text { Capacidad de Carga } \\
\text { Turística }\end{array}$ & Senderos y de Ríos \\
\hline
\end{tabular}




\begin{tabular}{|c|c|}
\hline EVIDENCIAS & TIPO \\
\hline $\begin{array}{c}\text { Inventarios de } \\
\text { especies }\end{array}$ & De Flora y de Fauna \\
\hline
\end{tabular}

Fuente: PETT (2012 y 2016).

Por su parte el anexo 2, muestra una síntesis de los resultados de elaboración de evidencias por cada ámbito, de acuerdo a cada uno de los descriptores, donde se indican las actividades necesarias para crear las evidencias para las comunidades metas del PETT.

Proceso de campañas comunitarias: Aunque forma parte de la fase anterior, se detalla como otro proceso (tabla 3), porque involucra actividades de articulación a lo interno de las comunidades y con instituciones regionales; en este caso, se apoya en la gestión y ejecución de campañas de limpieza y rotulación (vías, negocios de hospedaje y alimentación, zonas protegidas, sitios arqueológicos, recursos y atractivos turísticos) en conjunto con organizaciones de base comunitaria de las comunidades involucradas y el apoyo de algunas instituciones como Municipalidades, Ministerios e instituciones estatales, privadas y ONGs.

Tabla 3: Campañas comunitarias para la implementación de buenas prácticas de sostenibilidad

\begin{tabular}{|l|l|}
\hline \multicolumn{1}{|c|}{ CAMPAÑAS } & \multicolumn{1}{c|}{ TIPO } \\
\hline Rotulación & $\begin{array}{l}\text { De Prevención de riesgos y emergencias, } \\
\text { De acceso } \\
\text { De Recursos } \\
\text { De información }\end{array}$ \\
\hline Recolección de residuos Solidos & $\begin{array}{l}\text { Orgánicos } \\
\text { Reutilizables } \\
\text { Tóxicos o peligrosos }\end{array}$ \\
\hline Tratamiento de residuos líquidos & Creación de Biojardineras \\
\hline Reforestación & $\begin{array}{l}\text { Árboles Nativos } \\
\text { Frutales }\end{array}$ \\
\hline Ferias Comunitarias & Para la promoción y venta de productos locales \\
\hline
\end{tabular}

Fuente: PETT (2016). 
Las siguiente fotografías, muestran los resultados de las campañas de rotulación en las comunidades metas del PETT, la foto 1, muestra la información del sendero Caballito, para visitar el mirado con el mismo nombre, en la comunidad de Caballito, en la Península de Nicoya, Guanacaste. Por su parte la Figura 2, presenta la rotulación con información de las diferentes iniciativas de turismo, de la cuenca media del río Pacuare, Turrialba, en la provincia de Cartago.

Foto 1: Rotulación de la información del Sendero Caballito, Península de Nicoya, Guanacaste

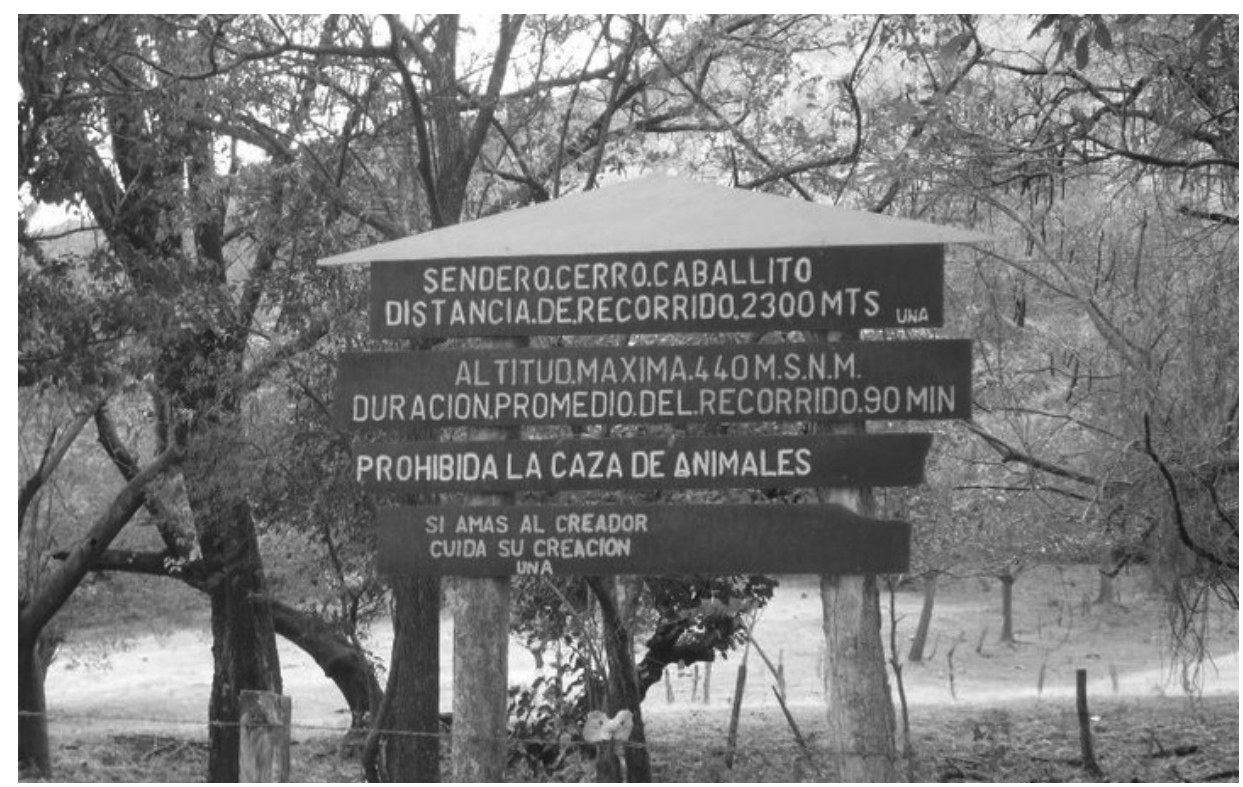

Fuente: PETT (2012). 
Foto 2: Resultados de la campaña de Rotulación en las comunidades del río Pacuare, Turrialba, Cartago

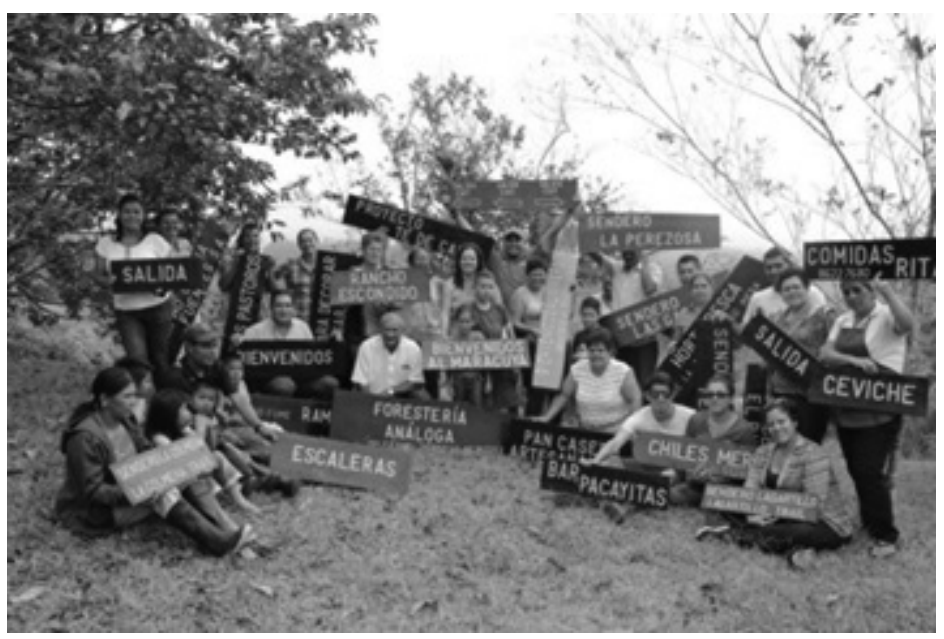

Fuente: PETT (2016).

Diseño del plan de sostenibilidad: Se realizan talleres participativos por comunidad, para el diseño del plan de sostenibilidad, en el que se refleje el compromiso de la organización con la implementación de buenas prácticas de sostenibilidad luchando por el buen estado del entorno natural y cultural de la comunidad, en este se incluyen los siguientes aspectos.

Visión y Misión: Como una buena práctica de sostenibilidad es necesario que la organización tenga una misión y una visión, que además deben ser visible en sus instalaciones, para el conocimiento por los visitantes y la comunidad.

El aspecto, más importante del plan son las principales buenas prácticas y las personas responsables de cada una, con el fin de tener un control de las diferentes variables que componen el plan. Entre las buenas prácticas a destacar en este plan están las siguientes:

Medidas de ahorro de agua: Consiste en seguir el historial de consumo de agua mediante una bitácora con la información de los recibos por mes. En esta se toma en cuenta, el plan de mantenimiento de las instalaciones y se define el encargado de esta área, que debe establecer una meta de consumo mensual.

Medidas de ahorro de energía: Incluye la revisión de instalaciones y mantenimiento preventivo mediante bitácoras y un encargado de mantener el 
historial de consumo de energía de los recibos por mes. También se debe definir una meta de consumo mensual.

Medidas para reducción de la contaminación por residuos: Para reducir la contaminación se deben realizar campañas de limpieza en la comunidad, clasificar los desechos, fomentar el uso de productos reciclables en las actividades y no utilizar estereofón en ninguna presentación, utilizar vajilla y utensilios de cocina no desechables, comprar refrescos en envases retornables. Informar a los visitantes y a la comunidad en general sobre la necesidad de mantener la comunidad limpia mediante la rotulación de las instalaciones y la comunidad en general.

Protección de flora y fauna Este apartado incluye medidas parar, la protección y recuperación de especies propias de la comunidad, denunciar la caza ilegal y la extracción de especies, no tener ningún animal en cautiverio, no usar comederos para ningún tipo de animal silvestre y rotulación en la comunidad con esta información.

Apoyo sociocultural: Una forma de demostrar el apoyo sociocultural es gestionando capacitaciones de acuerdo a las necesidades de la comunidad, facilitar instalaciones para realizar actividades comunales, apoyar la compra de productos locales, diseño de códigos de ética contra el abuso de menores de edad y la venta de drogas y mencionar la leyes que lo regulan.

\section{Fomentar actividades artísticas, culturales y deportivas de la comunidad y promocionarlas en las instalaciones de la organización.}

Información a visitantes: Las evidencias de la sostenibilidad deben ser palpables y son los visitantes los primeros en identificarlas, esto además de crear buena imagen, será una buena forma de promocionar es por eso se debe informar a los visitantes sobre las buenas prácticas de sostenibilidad de la empresa y organización. Estas se presentan mediante rotulación, folletos, pizarras informativas, la cartilla del visitante, registro de visitantes, manual del visitante, entre otras.

Lectura y validación del plan de sostenibilidad: Los miembros de la organización, leen el plan de sostenibilidad, lo discuten, lo validan y se comprometen a implementarlo y actualizarlo de acuerdo a las necesidades. 


\section{Consideraciones finales}

El Turismo Rural Comunitario, por sus características se presta para el desarrollo y diversificación de las actividades socioeconómicas en las comunidades involucradas, siendo las buenas prácticas de sostenibilidad una herramienta que permite cumplir con las exigencias de la demanda y los agentes de mercado a nivel nacional e internacional.

El diseño del plan de sostenibilidad turística, en las organizaciones o iniciativas de Turismo Rural Comunitario, es el primer paso para optar a cualquier certificación de sostenibilidad nacional o internacional, además no requieren de gran inversión, tampoco precisa de experiencias previas y se pueden replicar al interior de las organizaciones y la comunidad en general.

Los procesos de evaluación, reflejan las debilidades y fortalezas de cada una de las organizaciones e iniciativas involucradas, las cuales se deben tomar en cuenta en el diseño del plan de capacitación, el cual se debe adaptar a las características particulares de cada comunidad.

Estos procesos deben ser base para fomentar la creación de encadenamientos entre comunidades y articulaciones con instituciones públicas y privadas y ONGS, que promocionen los diferentes productos locales.

La implementación de esta metodología ha demostrado la importancia de los procesos participativos, para el empoderamiento del plan por parte de la comunidad, al no ser un proceso impuesto por un agente externo.

El PETT, por medio de sus diferentes proyectos de extensión universitaria, ha logrado validar y adaptar esta metodología, en diferentes comunidades, demostrando que es posible replicarla en comunidades con potencial de desarrollo turístico.

\section{Referencias}

ASOCIACIÓN DE PEQUEÑOS HOTELES DE COSTA RICA. Guia de Gestión Sostenible, para hoteles en crecimiento: herramientas para obtener y mantener el CST. Apéndice de Autoevaluación con preguntas del CST. San José, Costa Rica, 2009.

CÁMARA OFICIAL DE COMERCIO E INDUSTRIA DE GUADALAJARA. Guia de buenas prácticas ambientales en el sector turismo rural. Plan de formación, 
sensibilización, análisis de necesidades y creación de estructuras para las PYMES y profesionales autónomos de la provincia de Guadalajara, México, 2004.

GUEREÑA, A. "Protección ambiental y de personas en turismo de aventura”. En: Auge del turismo rural comunitario en Costa Rica, AMBIENTICO, v. 150, pp. 14-8, Universidad Nacional, Costa Rica, 2006.

ICT. “Plan Nacional de Desarrollo Turístico de Costa Rica 2017-2021”. 2017.

OMT. "Agenda para planificadores locales: Turismo sostenible y gestión municipal”. Edición para América Latina y el Caribe. Madrid, España, 1999.

PETT. "Informe final del proyecto Fortalecimiento de la oferta local por medio de las buenas prácticas de sostenibilidad turística en las comunidades locales. Caso de la península y el golfo de Nicoya", Fondos FUNDER, Universidad Nacional, Costa Rica, 2012.

. "Informe final del proyecto Fortalecimiento de empresas productivas y de turismo comunitario en la cuenca media del Pacuare, Fondos CONARE. Universidad Nacional, Costa Rica, 2016.

RAINFOREST ALLIANCE. Buenas prácticas para turismo sostenible, 2008.

RAINFOREST ALLIANCE. Guia de buenas prácticas de turismo sostenible para comunidades de Latinoamérica, 2009.

REPÚBLICA DE COSTA RICA. "Ley de Fomento del Turismo Rural Comunitario". La Gaceta, n. ${ }^{\circ}$ 191, San José, Costa Rica, del 1 de Octubre de 2009. 


\section{ANEXOS}

ANEXO 1: Formulario de evaluación de sostenibilidad turística para iniciativas de TRC

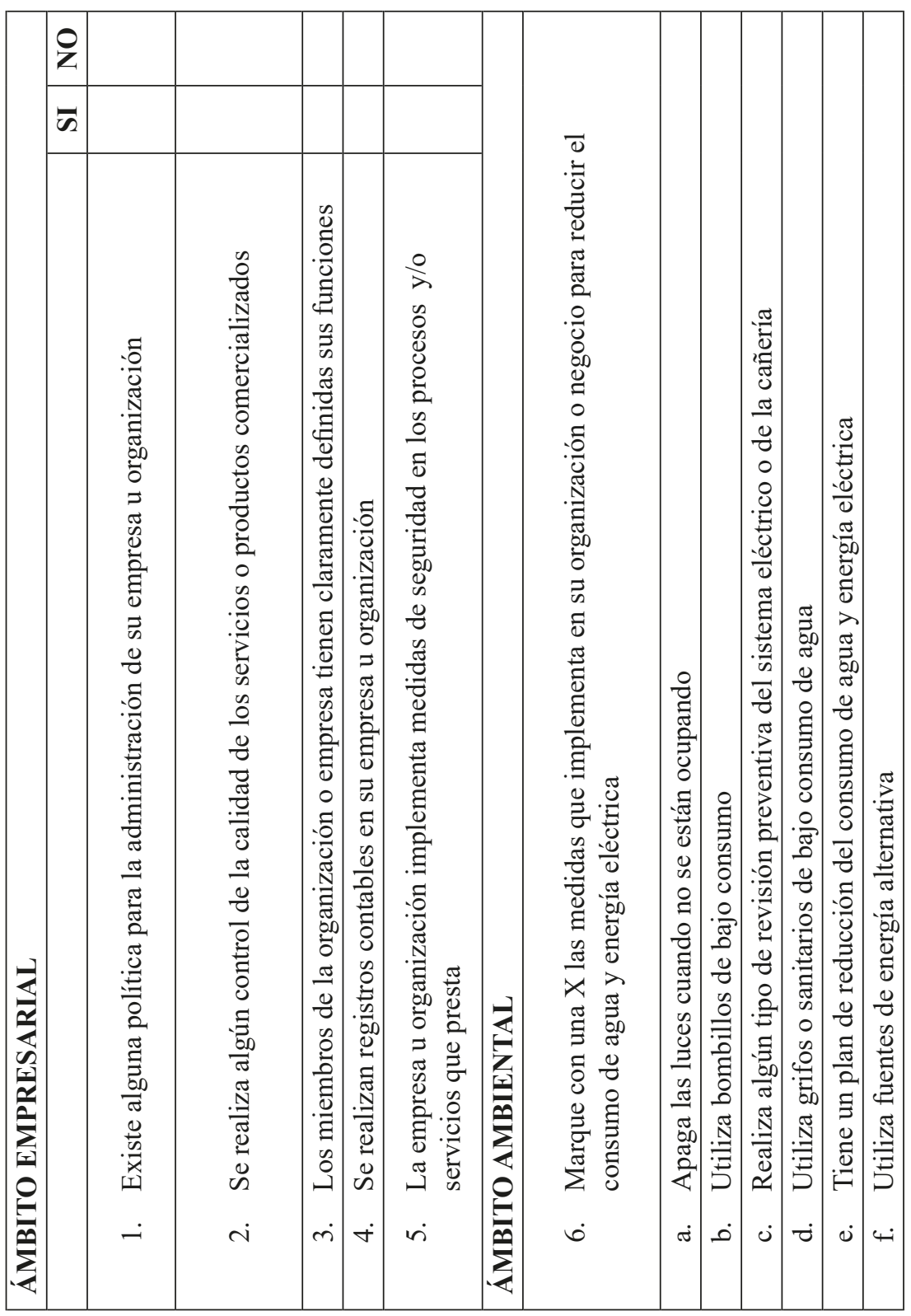




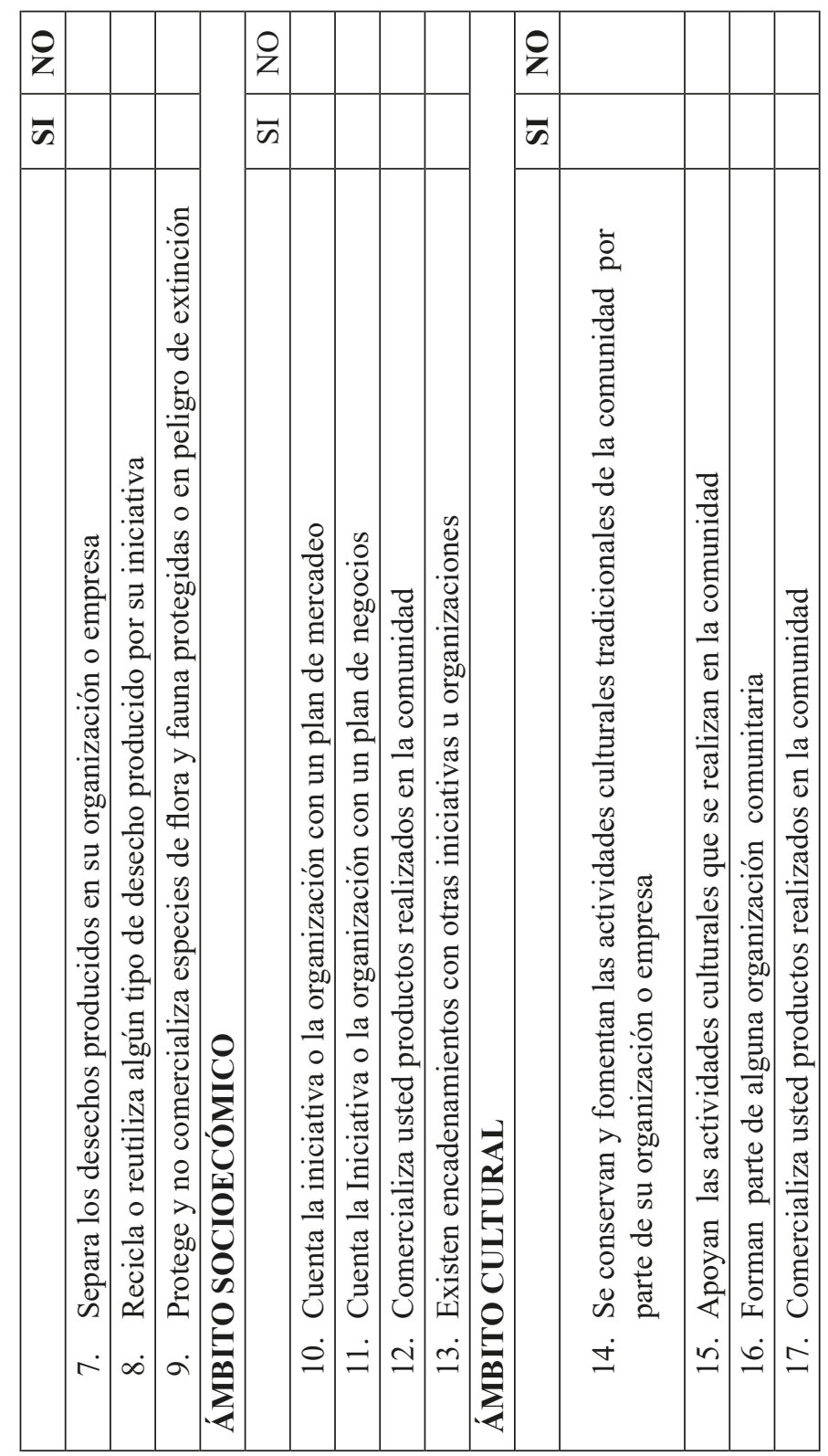

Fuente: Adaptado de PETT (2012). 
ANEXO 2 - Síntesis de evidencias para el plan de sostenibilidad en TRC, por entorno

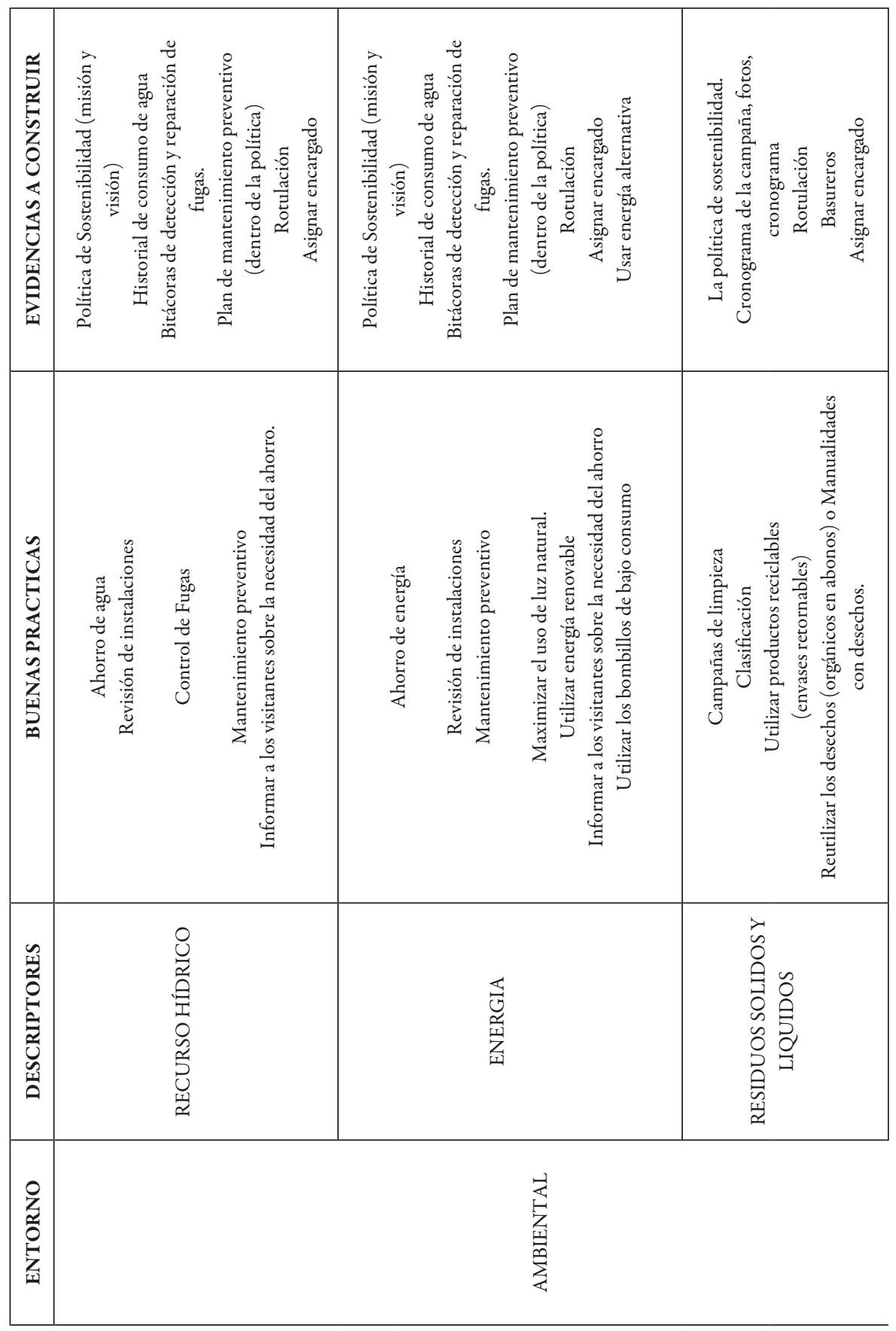




\begin{tabular}{|c|c|c|c|c|c|}
\hline 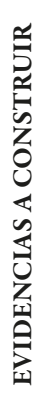 & 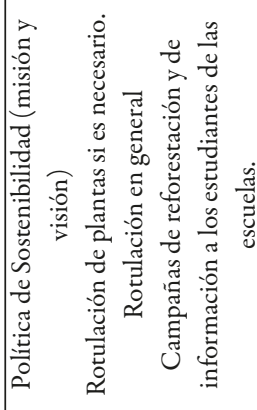 & 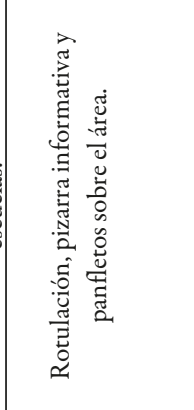 & 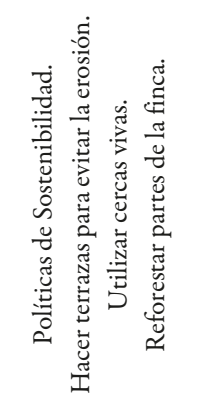 & 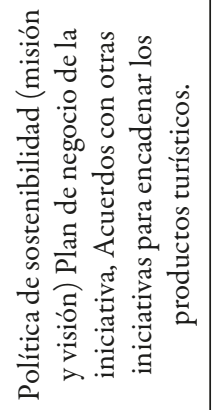 & 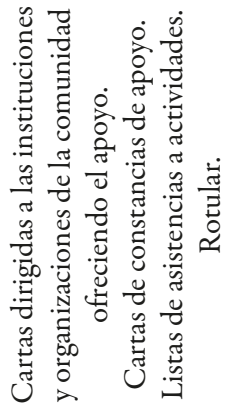 \\
\hline 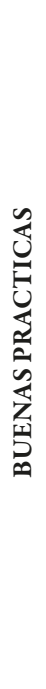 & 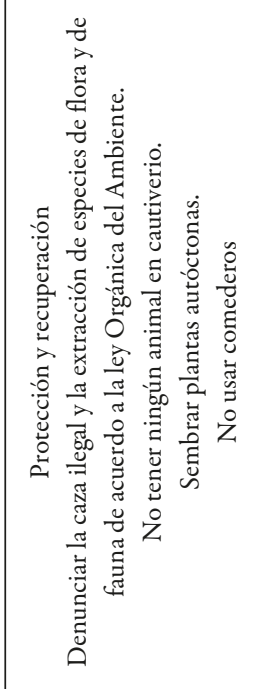 & 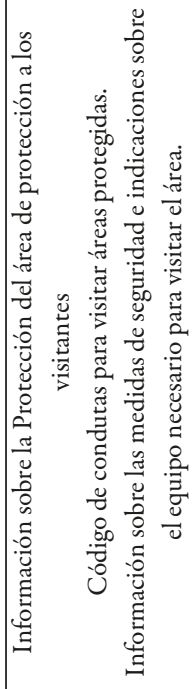 & 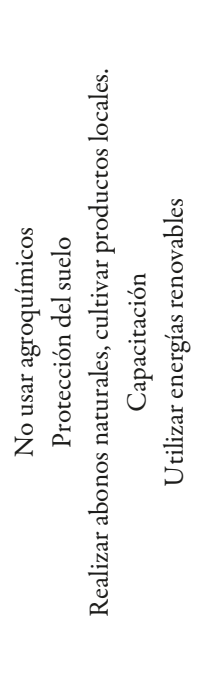 & 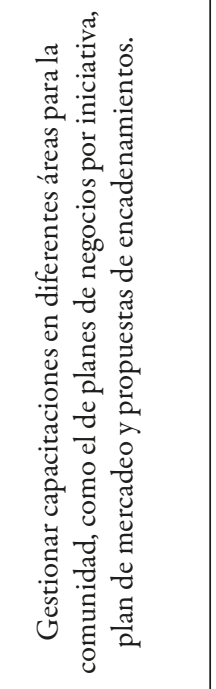 & 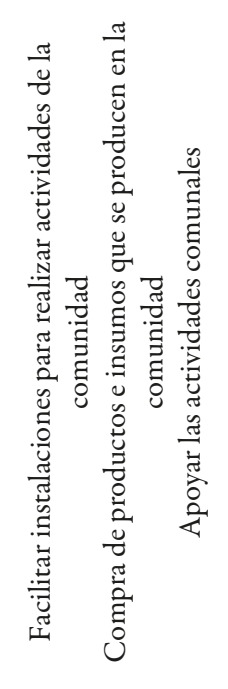 \\
\hline 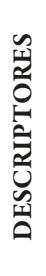 & 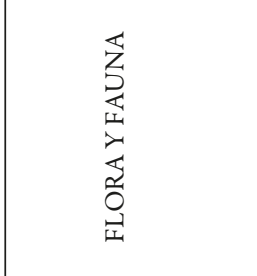 & 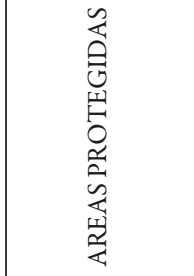 & 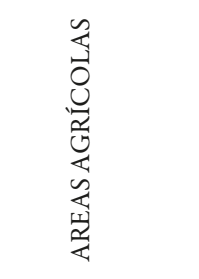 & 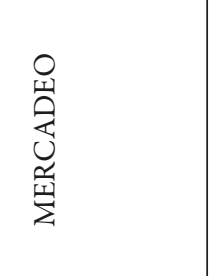 & 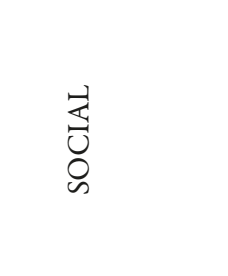 \\
\hline 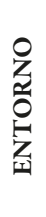 & & 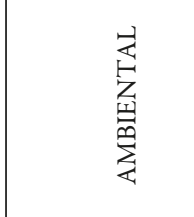 & & 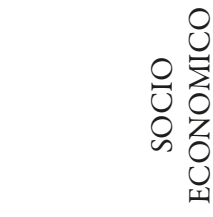 & \\
\hline
\end{tabular}


214 Estudos territoriais no Brasil e na Costa Rica

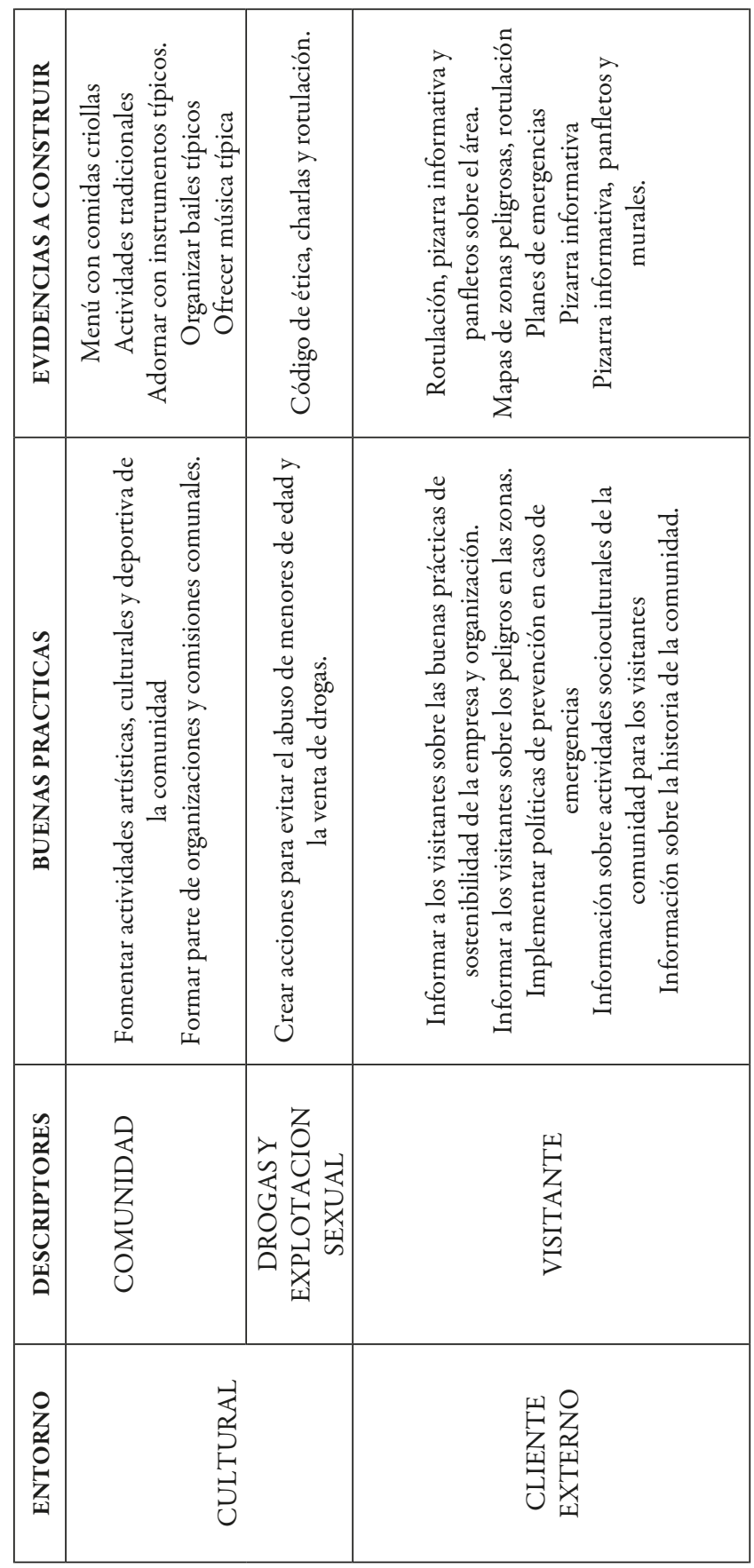

Fuente: Elaboración propia, adaptado del PETT (2012 y 2016). 


\section{Geografía de las juventudes: corporeidad y espacialidad urbana}

Iliana Araya Ramírez ${ }^{1}$

\section{Introducción}

La juventud es una categoría de análisis de lo social, situada en un tiempo histórico particular y en un espacio cultural definido; donde los jóvenes son una construcción sociocultural de determinada sociedad que se expresa en sus prácticas sociales y culturales. Este grupo etario se apropia de los espacios que devienen en lugares en la cotidianidad, la experiencia de habitar los lugares conforma un conjunto de relaciones, y a la vez, éstas se explican por las estructuras y las prácticas socio-espaciales de cada ciudad en particular. De acuerdo a la localización geográfica, la juventud participará en la vida urbana para apropiarse de los lugares, aunque algunas veces podrá ser excluido de estos (Horschelmann y Van Blerk, 2013).

De acuerdo con Aguilera (2009) la categoría de juventud asume diferentes enfoques: el sociodemográfico, el psicológico y el sociocultural. El primer enfoque, se alude desde el campo biológico muy vinculado con la edad, al estado y las capacidades del cuerpo; también se aborda como un proceso de aprendizaje de las normas sociales en tránsito hacia la integración social. Según Feixa (2008), la juventud se la considera "una fase de la vida individual comprendida entre la pubertad fisiológica (condición natural) y el reconocimiento del estatus adulto (condición cultural), la juventud es una condición universal” (Aguilera, 1999, p. 16) que se encontrará en todas las

\footnotetext{
Académica de la Escuela de Ciencias Geográficas. Licenciada en Geografía Humana, Máster en educación, doctoranda en Ciencias Sociales, Iliana.araya.ramirez@una.cr
} 
sociedades y momentos históricos. La crítica a este enfoque consiste en que la juventud no es un concepto universal, dadas las diferencias culturales, de clase y género; de igual forma, la edad restringe la complejidad de los significados de juventud debido a que las fronteras entre la juventud, la infancia y la edad adulta son ambiguas y cambiantes de acuerdo con cada tiempo y lugar (Rodó y I Castany, 2016). De igual forma, los ritos de pasaje van desapareciendo en los distintos contextos culturales (Margulis, 2001).

El enfoque psicológico se asocia con las etapas de la psicología del desarrollo y los procesos de maduración psicobiológica; asimismo, se encuentran otras perspectivas centradas en la estructuración de la identidad individual y colectiva. Por su parte, el enfoque sociocultural conceptualiza la juventud como una construcción que articula miradas generacionales, enfoque de derechos, acción colectiva y de cultura; y la sociabilidad juvenil (Aguilera, 2009). En este enfoque, la juventud está cruzada por la diversidad en sus acciones sociales y manifestaciones culturales, especialmente, en los espacios públicos de las ciudades (Domínguez, 2010).

Para Castillo et al. (2010), la juventud muestra algunas particularidades:

Es situacional, responde a contextos delimitados en un tiempo y espacio concretos. Es construida, a partir de procesos de disputa y negociación de los significados con el grupo de adultos más próximos; los cuales delimitan la pertenencia o exclusión al grupo juvenil. Es variable. Se construye y reconstruye permanentemente en la interacción social. Se produce en lo cotidiano. Sus ámbitos de referencia son íntimos, cercanos, familiares: el barrio, la escuela, el trabajo, la música, los estilos, la moda, Internet, los medios de comunicación, entre otros. Es transitoria. Depende de los tiempos biológicos y socioculturales que los integran o expulsan de la condición juvenil, está construida a partir de las relaciones de poder evidenciadas en las construcciones discursivas dominantes y totalizadoras, que cuestionan otras formas subjetivas de vivir la juventud.

La diversidad de la sociedad actual en los ámbitos económicos, sociales, políticos y culturales conducen la heterogeneidad de las personas jóvenes, ya sea por su clase social, el género, raza o etnia, creencias religiosas, adscripciones políticas o lugar de procedencia. Además, el pluralismo, el estallido cultural de 
los últimos años se manifiestan, privilegiadamente, entre los jóvenes que ofrecen un panorama sumamente variado y móvil que abarca sus comportamientos, referencias identitarias, lenguajes y formas de sociabilidad (Domínguez, 2010 y Margulis, 2001).

El objetivo de este ensayo consiste en analizar las perspectivas teóricas en la construcción de la espacialidad urbana desde la corporeidad y las emociones por parte de las personas jóvenes. En la primera parte se aborda la espacialidad urbana desde la perspectiva de la juventud y su diferenciación según sean sus características respecto al género, la clase y el lugar de precedencia. En el segundo apartado se conceptualiza al espacio público y su función social como un lugar donde la juventud establece relaciones sociales a partir de las cuales cimenta su espacialidad; destaca la importancia de la alfabetización callejera como parte de las formas de apropiarse de los lugares. En el tercer aparatado plantea la relación entre corporalidad, espacialidad y emociones y la forma que esta deriva en prácticas socio espaciales, ya sea de permanecer o desplazarse; en este sentido la experimentación del lugar deviene de la actuación y la convivencia en la ciudad. Finalmente, el último apartado se propone las relaciones proxémicas en las escalas de la espacialidad urbana elaboradas a partir de las relaciones sociales que inician en la escala del cuerpo, la casa, la calle, el barrio, la ciudad y el ámbito metropolitano.

\section{Juventud y espacialidad urbana}

La juventud ha sido muy poco estudiada dentro de las espacialidades urbanas y el análisis de las ciudades, a pesar de ser uno de los mayores grupos demográficos a nivel global. Al constituirse el mayor grupo demográfico, las personas jóvenes son capaces de hacer y rehacer, crear y destruir, transformar, transgredir, negociar y apropiarse de los espacios. Estos jóvenes viven, trabajan, estudian reconstruyen la ciudad mediante sus actividades cotidianas (Skelton y Gough, 2013). De ahí, la importancia de estudiar este grupo etario, entender la espacialidad urbana. La forma en que construyen la ciudad conduce a la interrogante:

¿Qué es una ciudad? Un lugar con mucha gente. Un espacio público, abierto y protegido. Un lugar, es decir, un hecho material productor de sentido. Una concentración de puntos de encuentros. En la ciudad lo primero son las calles 
y plazas, los espacios colectivos, sólo después vendrán los edificios y las vías (espacios circulatorios) (Borja y Muxí, 2000, p. 13).

Los espacios públicos de la ciudad no son espacios neutros, ni asexuados; al contrario, las lógicas temporales y espaciales designan el acceso al espacio público de acuerdo a la condición etaria, de género, de clase, del lugar de proveniencia, entre otras. La presencia en la calle no es la misma para una mujer que para un varón; el patriarcado determina unos roles para cada género y disciplina los cuerpos para comportarse de una forma adecuada en el espacio público. Por lo tanto, el uso del espacio público y la experiencia del mismo en el barrio o en la ciudad variarán en función del género, y los significados que se otorguen a los espacios también podrán ser distintos (Rodó y I Castany, 2016; I Guitart et al., 2014).

Actualmente, la mayor parte de las personas jóvenes crecen, habitan y trabajan en las ciudades. La juventud conforma el grupo etario más demandante y generador de espacios; estas condiciones están dadas por la transición que enfrentan al querer autonomía en el hogar y las dificultades para establecer su propio espacio privado. La espacialidad urbana que se asume para este grupo proviene de la concepción de espacio como un producto social, “[...] el resultado de la acción social, de las prácticas, las relaciones, las experiencias sociales, pero a su vez es parte de ellas" (Lefebvre y Nicholson-Smith, 1991, p. 11) donde se muestra una relación indisociable entre las acciones y los sujetos que construyen el espacio público, o sea la ciudad, la cual está materializada en sus objetos materiales e inmateriales ¿Cuál es la relación de las personas jóvenes con la ciudad? El espacio público y la ciudad se transforman por medio de las prácticas socio espaciales de apropiación de los lugares, tales como las de permanecer en casa, de trabajo, de estudio, de consumo, actividades culturales, sociales, recreativas, deportivas. Este conjunto de relaciones entre las acciones o prácticas de los sujetos jóvenes recrean las ciudades y sus dinámicas espaciales de formas complejas y variadas.

\section{Uso y apropiación de espacios públicos: una mirada desde las personas jóvenes}

La literatura muestra relación compleja y contradictoria entre las personas jóvenes y el espacio público. Si bien la apropiación del espacio deviene 
en los lugares "Lo que define el lugar son las prácticas socio espaciales, las relaciones sociales de poder y de exclusión; por eso los espacios se superponen y entrecruzan y sus límites son variados y móviles" (McDowell, 2000, p. 15). De esta forma, los espacios públicos son lugares concretos y simbólicos, construidos por medio de las prácticas socio espaciales y territorializados por los diferentes grupos sociales (Gough Y Franch, 2005). Para Massey (1998), el control de la espacialidad, por parte de la juventud, añade un ingrediente activo en los procesos sociales de disputa respecto a la apropiación del espacio.

El espacio público está diseñado para adultos, según sus necesidades e intereses, y por adultos: un espacio ordenado, limpio y purificado. Por lo tanto, prevalece una visión hegemónica del espacio, donde la juventud queda excluida o restringida. Este proceso de producción del espacio como espacio adulto es lo que se llama "adultificación del espacio público", dado que tales espacios se relacionan con comportamientos inapropiados, por ejemplo, el uso de drogas. Prevalece la concepción dicotómica que se tiene acerca de los jóvenes, como personas a proteger y/o como una amenaza; lo cual conduce a su exclusión del espacio público (I Guitart et al., 2014; Rodó y I Castany, 2016).

Las investigaciones mencionadas definen el espacio público, como un lugar construido por la cultura y la sociedad, con una importante función social en la construcción de la diferencia, la semejanza y la identidad, porque su acceso es una condición necesaria para el ejercicio de la ciudadanía (Van Lieshout y Aarts, 2008). El espacio público sirve para normalizar y naturalizar ciertos comportamientos. La hegemonía cultural de una nación o de una sociedad se constituye en el poder de la mayoría, y se restablece a través de la práctica social. El grupo dominante de la sociedad asume el poder de definir usos apropiados del espacio y los comportamientos públicos. A menudo, la sociedad civil no está consciente de la forma que están normadas las prácticas (Ehrkamp, 2008).

La tipificación del espacio público utilizado por las personas jóvenes fue clasificada en espacios abiertos y espacios cerrados. Los primeros corresponden a aquellos donde la gente joven se siente bien, los límites son indefinidos, el sistema de valores es diverso; existe tolerancia a la diversidad, incluso es celebrada; sus límites no siempre están vigilados y la multiculturalidad es dominante. Incluyen lugares como complejos deportivos, los carnavales y festivales. Por su parte, en los espacios cerrados los límites están muy bien definidos, el sistema de valores está normalizado con valores dominantes, la diferencia y la diversidad no son toleradas; prevalece la preocupación con el mantenimiento de los límites, 
con altos niveles de vigilancia, prevalece lo monocultural. Ejemplos de estos lugares son los centros comerciales, iglesias, escuelas, espacios donde sólo son bienvenidos aquellos que pertenecen y se comportan (Malone, 2002). A partir de esta tipificación se derivan prácticas socio espaciales de exclusión social en los espacios cerrados.

Los espacios públicos cerrados donde interactúan los jóvenes son lugares con protocolos regulatorios; ya que los adultos muestran incomodidad cuando las personas jóvenes transgreden y cuestionan la hegemonía espacial de la edad adulta, creando un "tercer espacio" que refleja su lugar entre la adultez y la infancia (Matthews et al., 2000). El "tercer espacio" corresponde al espacio vivido por las personas jóvenes, un lugar de hibridación cultural que se encuentra en la moda, la música, la gastronomía y las prácticas socio espaciales específicas de este grupo etario. La aspiración de un espacio público abierto, con escasa supervisión y de libertad para encontrarse con otras personas de forma no controlada, o por lo menos no al mismo nivel que dentro del hogar.

Los estudios realizados sobre la relación de la juventud con el espacio público urbano destacan la relevancia que tiene la calle, como lugar de autonomía, de construcción de identidades personales y colectivas. En las sociedades occidentales se ha demostrado que para muchos jóvenes la calle sigue siendo una parte importante de su vida cotidiana y de hecho el espacio de la calle es a menudo el único espacio autónomo que los jóvenes son capaces de obtener por sí mismos. En un estudio realizado con los jóvenes de Recife se concluyó que la calle es un importante espacio para reunirse con amigos y pasar el rato, aunque se mostraron diferencias muy claras respecto a la clase social (Gough y Franch, 2005). En otro estudio con jóvenes en Sao Paulo se señala de nuevas formas de sociabilidad entre los jóvenes que habitan los barrios periféricos de las grandes ciudades, la socialización se origina en las calles, las esquinas y lugares de encuentro; ahí se crean relaciones de amistad y ocio, además de enfrentar la violencia urbana y la lucha por la supervivencia (Sposito, 1993).

El espacio público es un lugar para hacer amistades, mientras que durante la infancia las amistades se conforman por medio de redes sociales basadas en el parentesco y la condición de clase, género, lugar de origen. En la juventud las tecnologías propician amistades en otras esferas por medio de las redes sociales (Bunnell et al., 2012).

El espacio público y la calle asumen una función central en formación de sujetos. El espacio público, en general, y la calle, de manera más específica, 
tiene un papel fundamental en la juventud como lugar de aprendizaje y de construcción del yo (Rodó y I Castany, 2016).

De ahí que la calle es un lugar relevante en la vida de las personas jóvenes, donde pueden conservan autonomía sobre el espacio. La calle se transforma en un universo impersonal, un lugar de autonomía y de construcción de identidades personales y colectivas. A su vez, la presencia de los jóvenes en estos lugares es visto como una molestia o incluso una amenaza. Aquí aparecen una serie de regímenes reguladores y de vigilancia por parte de los padres, los vecinos, la policía y otros. El temor a la violencia es el principal argumento utilizado por los padres para intentar controlar los movimientos de sus hijos (Gough y Franch, 2005).

La calle es un lugar donde se transforma y consolida la identidad de las personas jóvenes; por tanto, permanecer fuera de la casa les otorga a los jóvenes un sentido de libertad. El concepto de "aprendizaje de la calle" ("street literacy”) hace referencia a "los procesos dinámicos de producción experiencial de conocimiento y la construcción del yo en un contexto específico, el espacio urbano público" (Cahill, 2000, p. 252). Es un proceso que consiste en entender el mundo a través de la interacción y experiencia en el ambiente, el cual privilegia el conocimiento local informal, basado en las experiencias personales y conforma un saber de la calle que se transmite a través de las generaciones. La "alfabetización callejera" en esta investigación se abordará como una práctica socio espacial que expresa la adquisición de habilidades para el desarrollo social y experiencial del conocimiento informal, una práctica social y compartida.

El concepto de alfabetización callejera está inspirado en las teorías interaccionistas sociales de Lev Vygotsky, quien afirma que el lenguaje produce y reproduce formas culturales de comportamiento. Así, el lenguaje es el puente conceptual que la persona utiliza para mediar su relación externa e interna con el entorno; por medio de este organiza y construye el yo. Vygotsky argumenta que los sistemas de signos, como el lenguaje son el producto del desarrollo social; no está dado de forma natural, sino que media la manera en que nos expresamos y nos comprendemos a nosotros mismos (Vygotsky, 1978). De esta forma, la experiencia en el espacio público está mediada por la producción y reproducción de las formas culturales de comportamiento (Cahill, 2000). 


\section{Corporalidad, espacialidad y emociones}

La discusión contemporánea que gira en torno a la corporalidad, el espacio y la afectividad emerge con intensidad en los últimos años y ocupan un lugar central en la reflexión en la teoría social (McDowell, 2000; Lindón, 2011; Lindón, 2012a; Aguilar, 2013; e Aguilar, 2014). Dentro de la teoría social y el feminismo emerge el estudio del cuerpo, desde la perspectiva de clase, consumo y las relaciones sociales entre personas y lugares a través de los trabajos de (Baudrillard, 2009; I Guitart, 2012; Bourdieu, 2008).

La relación entre corporalidad y espacialidad está abordada en La producción del espacio (1974), donde señala que la práctica espacial "engloba producción y reproducción, lugares específicos y conjuntos espaciales propios de cada formación social; práctica que asegura la continuidad en el seno de una relativa cohesión" (Lefebvre y Lorea, 2013, p. 92). Las prácticas socio espaciales están referidas a las actividades cotidianas incorporadas en la experiencia espacial de las personas.

Si bien, las investigaciones más consolidadas hacen referencia al cuerpo, la corporeidad y las emociones, estas dejan de lado la espacialidad. El estudio de las prácticas socio espaciales, la subjetividad y lo imaginario necesariamente deben integrar la corporalidad y las emociones (Lindón, 2012). Esta autora recurre al betweenness, entendido como una zona de transición y de intersección del conocimiento social, para aproximarse al estudio del cuerpo, las emociones y la dimensión espacial. De igual manera analiza las interacciones entre el cuerpo, la corporeidad, las emociones, la cotidianidad y los espacios de vida de los sujetos. Para esto, intersecta los conceptos de cotidianidad, subjetividad, las biografías y el sujeto a partir del lugar y la cotidianidad. Los sujetos que habitan los lugares configuran lo social y protagonizan la cotidianidad, la cual adquiere diversas formas según las prácticas espaciales que cada sujeto despliega. En tanto, la subjetividad se configura en las experiencias del sujeto social y son interdependientes de las prácticas, que a su vez son movilizadas en la cotidianidad. Por su parte, el sujeto corporizado por medio de la corporeidad deviene en emoción en un contexto socio-cultural particular en su espacio vivido (Lindón, 2012).

La aproximación al cuerpo desde la espacialidad proviene de las prácticas socio espaciales que configuran la subjetividad, así la memoria se activa en los recuerdos de tales prácticas. La relación entre la espacialidad y la corporeidad 
surge de la experiencia en la construcción activa del espacio, a partir del cuerpo. Desde la espacialidad destacan las prácticas de desplazamiento y las de permanecer. El cuerpo adquiere corporeidad en sus prácticas, en la experiencia de hacer, sentir, pensar y querer, la corporeidad

[...] es sentir y vivir el cuerpo en cuanto a saber pensar, saber ser y saber hacer. Es mediante la corporeidad que el individuo se apropia del espacio y el tiempo que le acontece, lo transforma y le da cierto valor. Por ello la corporeidad permite saber pensar, ser y hacer el espacio vivido (Lindón, 2012, p. 706).

De tal manera que esta construye la ciudad en la interacción social y la emoción es siempre corporeizada. Por lo cual, la construcción social de la ciudad desde la corporeidad conlleva la paradoja emocional de experimentar la ciudad, "actuar en ella, disputarla, marcarla, siempre en los contextos socioculturales específicos, en mundos intersubjetivos peculiares, en territorios particulares, en medio de ciertas formas materiales y encarnando así las diversas posibilidades históricas" (Lindón, 2015, p. 9). Aprender a convivir y vivir la ciudad conlleva una transformación de la corporalidad; así, el medio configura las diferencias individuales en las interacciones con los padres, familiares y grupo de compañeros y amigos.

En este espacio de convivencia el cuerpo va cambiando como resultado de esa historia, y siguiendo un curso contingente a esa historia [...] Esto se debe a la inercia corporal y no a que el cuerpo sea un lastre o constituya una limitación, es nuestra posibilidad y condición de ser (Maturama, 2008, p. 67).

La constante interacción entre la corporeidad, la emoción y la espacialidad produce cambios en la estructura urbana que perturban y a la vez gatillan la construcción social de la ciudad desde las personas jóvenes que la habitan.

En esta investigación, la construcción de la ciudad por parte de los jóvenes se elabora desde diferentes escalas: el cuerpo, la casa, el barrio, la ciudad, la metrópolis y las prácticas espaciales que realizan en la cotidianidad Hopkins (2013), a partir de las cuales construyen sus identidades expresadas en los lenguajes del cuerpo, donde se adaptan o se resisten. 


\section{Escalas de proximidad en la construcción de la espacialidad: el cuerpo, la casa, el barrio, la ciudad y la metrópolis}

La aproximación a la corporalidad es analizada desde la proxémica, entendida como la ciencia "que estudia el uso del espacio y la distancia corporal como una señal que regula las interacciones sociales" (Martínez, 2004, p. 138). En el libro La dimensión oculta de Hall (1987), el autor establece una clasificación de las distancias entre el uso del espacio y los cuerpos: a) la distancia íntima está reservada para contactos cercanos; en su fase cercana corresponde a "la distancia del acto de amor y de la lucha, de la protección y el confortamiento" (p. 143). En la fase lejana, con distancias entre 15 y 45 $\mathrm{cm}$, los cuerpos no entran fácilmente en contacto. b) La distancia personal "es el término que empleó Heidegger para designar la distancia que separa constantemente los miembros de las especies de no contacto” (p. 46). En la fase cercana de 45 a $75 \mathrm{~cm}$ la proximidad permite agarrar o retener a otra persona; en la fase lejana de 75 a $120 \mathrm{~cm}$ queda establecido el límite de la dominación física. c) La distancia social que mantiene situaciones normales de interacción se define como "la línea que pasa entre la fase lejana de distancia personal y la fase cercana de distancia social y señala el límite de dominación" (p. 148). En la fase cercana, de $120 \mathrm{~cm}$ a $2 \mathrm{~m}$, se trabajan asuntos impersonales, es empleada en reuniones sociales improvisadas e informales; en la fase lejana, de 2 a $3.5 \mathrm{~m}$ tiene un carácter más formal. La distancia social en la fase lejana es empleada para aislar o separar unas personas de otras. d) La distancia publica válida para actuaciones públicas "es la transición de la distancia social y personal a la distancia pública que está fuera del campo de la participación o la relación” (p. 152). En la fase cercana de 3.5 a 7.5 m se utiliza para ámbitos muy formales; en la fase lejana a 9 m queda reservada a los personajes públicos o actos públicos.

La proxémica posee un valor comunicativo, dado que las acciones e interacciones de las personas en el espacio permiten desarrollar las actividades y constituyen un lenguaje que puede ser analizado (Sánchez, 1990). En los espacios públicos la relación de proximidad entre la distancia íntima y personal conlleva a conflictos por la territorialidad y apropiación de los espacios. En consecuencia, el concepto de proxémica es clave para abordar la corporalidad desde las relaciones interpersonales.

La conceptualización de proxémica de Hall cambia dada la aceleración de la sociedad actual; un fenómeno característico de la sociedad global en la 
expansión del sistema capitalista, es una forma manifiesta de la compresión espacio temporal propuesta por Harvey, en donde las personas y los lugares que antes estaban distanciados ahora se aproximan. En este contexto de aceleración, las prácticas socio espaciales se abordan desde la vida cotidiana, así, las "dimensiones de la cotidianidad son consideradas junto a la corporeidad/ emocionalidad del sujeto y a su espacio-temporalidad [...] La espacialidad del sujeto lo hace necesariamente habitante de diversos lugares en temporalidades específicas" (Lindón, 2011,p. 17). Las estrategias proxémicas asumen un carácter multidimensional de lo social, lo espacial y lo corporal; los acercamientos se concretan por dos caminos: el viaje y las tecnologías de la comunicación. En este caso,

Los territorios de la proximidad son practicados, recorridos; devienen en los lugares de encuentro con conocidos, representan seguridad y así son cargados de sentidos. Corporalmente son experimentados como los lugares de nuestro cuerpo, los lugares en los que corporalmente no emerge el estado de alerta, sino la confianza ante lo conocido (Lindón, 2011, p. 19).

Las personas jóvenes disfrutan tanto el contacto cara a cara como el mediado por las tecnologías en procura de la proxemia corporal y afectiva. La reducción experiencial del espacio vivido se manifiesta en las escalas de la casa, el barrio, la ciudad y la metrópolis. Es por esta razón, que habitar ciudades pequeñas favorece estrategias proxémicas relacionadas con la alfabetización del espacio construida desde la corporeidad para resolver su andar cotidiano. El cuerpo es la primera escala corporal entre yo y el otro. “[...] el cuerpo y sus movimientos, la forma en que ocupa un lugar, la legitimidad de los usos, la movilidad y las posturas, son regulaciones impuestas por un orden social determinado, así ocupar un lugar puede ser interpretado de forma concreta o simbólica" (Aguilar y Soto, 2013, pp. 6-7).

En las ciencias sociales, los usos sociales del cuerpo lo refrieren "como un objeto de consumo y signo a la vez y el lenguaje del cuerpo” (Martínez, 2004, p. 134). En la geografía el cuerpo es un lugar "Un cuerpo, aunque no todos los estudiosos de la geografía lo crean, es un lugar. Se trata del espacio en el que se localiza el individuo, y sus límites resultan más o menos impermeables respecto a los restantes cuerpos" (McDowell, 2000, p. 59). Mientras que el cuerpo remite a su dimensión material, la noción de corporeidad apunta su dimensión 
simbólica, a la forma de representar los diferentes valores, alude a una forma de conocimiento experiencial "incorporado" como lenguajes (Aguilar, 2014). A su vez, la corporalidad expresa la personalidad de los sujetos jóvenes, sus formas de relacionarse y los procesos de socialización. "La proximidad corporizada respecto al entorno barrial, desborda el territorio y el propio cuerpo, haciéndose extensiva a los otros que habitan el barrio". Sin embargo, esa otredad es difusa" (Lindón, 2011, p. 21).

A partir del cuerpo los sujetos jóvenes construyen los lugares donde habitan en interacción con otros; así, desde la escala del cuerpo se transita hacia otras como la casa, el barrio, la ciudad, la metrópolis. En este sentido, el cuerpo y las emociones organizan "una ventana para comprender la construcción social de la ciudad, de lo urbano y sus lugares, a través de los sujetos que la habitan corporal y emocionalmente" (Lindón, 2009, p. 6).

Por su parte, la casa constituye un referente a partir del cual las personas jóvenes construyen su relación con el entorno, con el barrio y de forma simultánea con aquello más allá del barrio, es decir, la ciudad (Lindón, 2006). La dicotomía entre la casa o el hogar y el mundo exterior es expresada por Tuan (2005), en el libro Cosmos y hogar: Un punto de vista cosmopolita. En el primer capítulo, Dos escalas y una autobiografia, el autor trabaja con dos escalas: hogar y cosmos; por medio de Topo, un personaje fundamental de la literatura inglesa clásica infantil: El viento en los sauces, de Kenneth Grahame (1908), Yi-Fu Tuan identifica la expresión ique agradable es volver a casa! (Tuan, 2005, p. 11) que afirma Topo cuando regresa a su madriguera. De acuerdo con Tuan, el ser humano alberga sentimientos contradictorios entre el hogar y el mundo exterior. Para los jóvenes, la casa significa un espacio familiar y de contención afectiva; a veces un refugio y otras un espacio de disputa fraternal, intergeneracional vinculado al género y la edad (Bastán y Paulín, 2016). La casa posee una doble expresión física y simbólica dada la interactividad entre las personas que la habitan, como institución asume los procesos de socialización, especialmente, en las primeras etapas de la infancia, básicas en la construcción de la identidad, lo que incluye la internalización de rol de género (Pacheco, 2001).

De acuerdo con Lindón (2006), el espacio vivido de la casa se expresa como "la entronización de la casa", es decir, la casa en un trono, donde la importancia de la casa adquiere un papel central respecto a la vida urbana. Para esta autora, la casa organiza la vida de las personas y está llena de recuerdos, de 
memoria, fantasías y aspiraciones (Lindón, 2011). En esta escala de proximidad la corporalidad está muy integrada a la percepción del espacio de la casa, a partir de un espacio egocéntrico (Pacheco, 2001).

La construcción de la espacialidad inicia en la infancia, desde la casa en relación con el barrio. El conocimiento directo o el conocimiento práctico espacial están construidos en la práctica de desplazamiento y manipulación de objetos mediante el lenguaje kinésico y lenguaje verbal en el aprendizaje de los lugares y objetos. Para Souto (1998), el lenguaje y el movimiento fortalecen el razonamiento y el aprendizaje de conceptos que conducen al dominio espacial de los niños.

En la escala geográfica del barrio las estrategias de proxemia corporal y afectiva están orientadas hacia una forma de regreso al barrio. En algunos casos la revalorización del barrio está asociada con la aceleración actual de la vida urbana. De igual forma, la reducción de la espacialidad cotidiana es una forma de contrarrestar la fatiga de la aceleración, por esta razón, la identificación con el barrio constituye una alternativa o forma de enfrentar la compresión espacio-temporal. El barrio podía devenir en territorios que otorgan seguridad (Lindón, 2011).

El barrio como categoría social urbana posee una delimitación geográfica y un sentido de pertenencia de las personas con ese lugar; también puede definirse por la forma en que las personas indican pertenecer a un barrio y les permite diferenciarse de otras que no pertenezcan a esa categoría social. Otras formas de pertenecer a un barrio y diferenciarse son: a) que no pertenezcan a nuestro barrio, b) que conozcan nuestro barrio, c) que sean también capaces de definirse en relación a su barrio (Valera y Pol, 1994). Para las personas jóvenes, esta escala de proximidad favorece los procesos de socialización por medio de las reuniones en las calles, las esquinas y otros puntos de reunión; a la vez permite un distanciamiento de la escala del hogar al enfrentar algunas situaciones que quizás no puedan controlar. Por tanto, la socialización en el barrio le permitirá madurar y entablar amistades que enriquezcan su proceso de identidad territorial.

En el ámbito metropolitano, los desplazamientos de las personas son cada vez mayores dada la aceleración de la vida cotidiana, la escala del barrio está circunscrita a la ciudad. Es aquí, donde se distingue con claridad la corporalidad contemporánea 
[...] en esta el cuerpo muestra sus maneras de procurarse y crear una espacialidad: sea desde la sumisión, y apego a las normas o desde sus rasgos creativos e innovadores [...] La estructura, la forma y las normas urbanas inciden en la elaboración de la corporeidad porque la urbe configura y legitima la forma en que los habitantes portan el cuerpo, el acto de sentarse, andar, los movimientos, las posturas, los gestos las estrategias de orientación (Aguilar y Soto, 2013, p. 8).

La práctica socio espacial de andar por la ciudad expresa la manera en que los jóvenes han construido su espacialidad, la cual queda plasmada en las formas de mostrar sus cuerpos, la indumentaria, los itinerarios que realizan, la música, sus hábitos de consumo y las formas de apropiarse de los lugares. Asimismo, las escalas proxémicas se traslapan y son difusas, ya que desde la infancia las experiencias de lugares lejanos forman parte de la espacialidad de los niños, mediante los viajes fuera del barrio y la ciudad.

\section{Consideraciones finales}

La juventud como categoría de análisis constituye un constructo socio cultural que está expresada en sus prácticas socio espaciales donde articulan los espacios públicos de las ciudades. A su vez estos espacios han sido configurados por la cultura y la sociedad; y cumplen la función social de construir la diferencia, la semejanza y la identidad de este grupo etario.

La espacialidad urbana respecto al uso del espacio público presenta variantes según sean las escalas de proximidad y las experiencias de las personas jóvenes con su cuerpo, la casa, el barrio, la ciudad y el ámbito metropolitano. De ahí que cabe plantear la interrogante ¿cómo varía la espacialidad según la condición de género y la escolaridad? ¿Cuáles prácticas socio espaciales configuran la espacialidad urbana de estos sujetos jóvenes?

En estas escalas de proximidad, la centralidad de la calle asume rasgos definitorios en la construcción de la espacialidad urbana ya que constituye un lugar de aprendizaje, de interacción y socialización para las persona jóvenes. De ahí que el concepto "alfabetización callejera" devela la adquisición de conocimientos informales y estrategias de sobrevivencia en el espacio urbano y presentan variantes según sea el nivel educativo o el lugar de proveniencia. En consecuencia, los conceptos de alfabetización callejera y corporeidad se 
interrelacionan mediante el lenguaje corporal; la calle constituye el lugar donde los sujetos jóvenes concretan los procesos de socialización.

Aunado a lo anterior la aceleración de la sociedad actual en la expansión del sistema capitalista transforma las dimensiones espacio temporales; también cambian las nociones de proximidad. Las relaciones entre corporeidad y emocionalidad asumen características distintivas; dado que el acercamiento y el alejamiento están mediados por las tecnologías de la comunicación.

Si bien la espacialidad urbana está configurada en diferentes escalas de proximidad que inicia en el cuerpo para luego traslaparse con las otras escalas de la casa, la calle, el barrio, la ciudad, el ámbito metropolitano, también hay un recorrer biográfico que inicia en la infancia. Aquí las practica socioespacial de andar y transitar se conjuga con el lenguaje kinésico y lenguaje verbal.

Finalmente, las formas de apropiarse del espacio están asociadas con aquellas maneras de pertenecer y relacionarse con los lugares; la calle y el barrio son los lugares donde los sujetos jóvenes y elaboraran una nueva espacialidad urbana como parte de un proceso dialéctico vinculado a los ambientes socioculturales, cargados de un alto valor simbólico por decodificar.

\section{Referencias}

AGUILAR, Miguel Ángel. "Corporalidad, espacio y ciudad: rutas conceptuales”. En GARCÍA, O. Cuerpo y afectividad en la sociedad contemporánea: algunas rutas del amory la experiencia sensible en las ciencias sociales. México: Universidad Autónoma Metropolitana - Azcapotzalco, 2014, pp. 317-46.

y SOTO, Paula. "Presentación". En Cuerpos, espaciosy emociones: aproximaciones desde las ciencias sociales. México: Editorial Miguel Ángel Porrúa, 2013.

AGUILERA, Oscar. "Los estudios sobre juventud en Chile: coordenadas para un estado del arte”. Última década, v. 17, n. 31, pp. 109-27, Santiago, 2009.

BASTÁN, Guido y PAULÍN, Horacio. "Identidades juveniles en escenarios de periferización urbana. Una aproximación biográfica”. Quaderns de Psicologia, v. 18, n. 1, pp. 35-52, 2016. 
BAUDRILLARD, Jean. La sociedad de consumo: sus mitos, sus estructuras. Madrid: Siglo XXI España Editores, S.A., 2009.

BORJA, Jordi y MUXÍ, Zaida. El espacio público: ciudad y ciudadanía. Barcelona: Electa, 2003.

BOURDIEU, Pierre. El sentido práctico. Madrid: Siglo XXI de España Editores, 2008.

BUNNELL, Tim et al. "Geographies of friendships". Progress in Human Geography, v. 36, n. 4, pp. 490-507, 2012.

CAHILL, Caitlin. "Street literacy: Urban teenagers' strategies for negotiating their neighbourhood”. Journal of youth studies, v. 3, n. 3, pp. 251-77, 2000.

CASTILLO, Analisa et al. "Aproximación al discurso juventud como construcción sociohistórico-cultural”. Última Década, pp. 43-58, 2010.

EHRKAMP, Patricia. "Risking publicity: masculinities and the racialization of public neighborhood space”. Social \& Cultural Geography, v. 9, n. 2, pp. 117-33, 2008.

FEIXA, Carles. De jóvenes, bandas y tribus. Barcelona: Ariel, 2008.

GOUGH, Katherine y FRANCH, Mónica. "Spaces of the street: socio-spatial mobility and exclusion of youth in Recife". Children's Geographies, v. 3, n. 2, pp. 149-66, 2005.

HALL, Edward. La dimensión oculta: enfoque antropológico del uso del espacio. Madrid: Ed. IEAL, 1987.

HOPKINS, Peter. Youngpeople, place and identity. Londres: Routledge, 2013.

HORSCHELMANN, Kathrin y VAN BLERK, Lorraine. Children, youth and the city. Londres: Routledge, 2013.

LEFEBVRE, Henri y LOREA, Ion. La producción del espacio: Madrid: Capitán Swing, 2013.

LINDÓN, Alicia. "La casa bunker y la deconstrucción de la ciudad”. Estudios Sociales y Humanisticos, v. 4, n. 2, pp. 18-35, 2006. 
. "La construcción socioespacial de la ciudad: el sujeto cuerpo y el sujeto sentimiento". Revista Latinoamericana de Estudios sobre Cuerpos, Emociones y Sociedad, n. 1, pp. 6-20, 2009.

. "Cotidianidades territorializadas entre la proxemia y la diaste-mia: ritmos espacio-temporales en un contexto de aceleración Territorialized everyday life between proxemics and diastemics: time-space rhythms in a context of acceleration". Educación Física y Ciencia, v. 13, pp. 15-34, 2011.

. "Corporalidades, emociones y espacialidades". Revista Brasileira de Sociologia da Emoção, v. 11, n. 33, pp. 698-723, 2012 a.

. "Del espacio público de las hexis corporales al de las afectividades brumosas y no discursivas". Cuerpos, Emociones y Sociedad, año 7, n. 17, pp. 8-19, 2015.

MALONE, Karen. "Street life: youth, culture and competing uses of public space". Environment and urbanization, v. 14, n. 2, pp. 157-68, 2002.

MARGULIS, Mario. "Juventud: una aproximación conceptual". En DONAS, Solum (complilador). Adolescencia y juventud en América Latina. 2001, pp. 41-56.

MARTÍNEZ, Ana. "La construcción social del cuerpo en las sociedades contemporáneas”. Papers: Revista de Sociologia, n. 73, pp. 127-52, 2004.

MASSEY, Doreen. "The spatial construction of youth cultures". Geographies of youth cultures, pp. 121-9, 1998.

MATTHEWS, Hugh et al. "The unacceptable flaneur: the shopping mall as a teenage hangout”. Childhood, pp. 279-94, 2000.

MATURANA, Humberto. Emociones y lenguaje en educación y politica. Santiago: JC Sáez Editor, 2008.

MCDOWELL, Linda. Género, identidady lugar: un estudio de las geografiasfeministas. Universitat de València, v. 60, 2000.

NATERAS, Alfredo. "Adscripciones identitarias juveniles: tiempo y espacio social". $E l$ Cotidiano, v. 63, n. 25, pp. 17-23, 2010. 
ORTIZ, Anna. "Cuerpo, emociones y lugar: aproximaciones teóricas y metodológicas desde la geografía”. Geographicalia, n. 62, pp. 115-31, 2012.

. "Procesos de apropiación adolescente del espacio público: otra cara de la renovación urbanística en Barcelona”. Boletín de la Asociación de Geógrafos Españoles, n. 65, pp. 37-57, 2014.

PACHECO, Xenia. Cuerpos y espacios: percepciones de las mujeres (tese). Universidad Nacional Costa Rica, 2001.

PONTES, Marilia. "A sociabilidade juvenil e a rua: novos conflitos e ação coletiva na cidade”. Tempo Social, v. 5, pp. 161-78, 1993.

RODÓ, María. "El acceso de la juventud al espacio público en Manresa. Una aproximación desde las geografías feministas de la interseccionalidad". Scripta Nova, Revista Electrónica de Geografía y Ciencias Sociales, n. 19, pp. 1-24, 2015.

y ESTIVILL, Jordi. ¿La calle es mía? 2016.

SÁNCHEZ, Francisco. La liturgia del espacio. Narea, Madrid: España, 1990.

SKELTON, Tracey y GOUGH, Katherine. "Introduction". Young people's im/mobile urban geographies, v. 50, 2013.

SOUTO, Xosé Manuel. Didáctica de la Geografía: problemas sociales y conocimiento del medio. Barcelona: Ediciones del Serbal, 1998.

TUAN, Yi-Fu. Cosmos y hogar: un punto de vista cosmopolita. Madrid: Melusina, 2005.

VALERA, Sergi y POL, Enric. "El concepto de identidad social urbana: una aproximación entre la psicología social y la psicología ambiental”. Anuario de psicologíal The UB Journal of psychology, n. 62, pp. 5-24, 1994.

VAN LIESHOUT, Maartje y AARTS, Noelle. "Youth and immigrants perspectives on public spaces”. Space and Culture, v. 11, n. 4, pp. 497-513, 2008.

VYGOTSKY, Lev. Mind in society: the development of higher psychological processes. London: Cambridge Harvard University Press, 1978. 


\section{El ordenamiento del territorio y los procesos en la elaboración de planes reguladores en Costa Rica}

Lidia Orias Arguedas

\section{Introducción}

Este capítulo tiene como objetivo abordar de manera sucinta, los conceptos teóricos relacionados con el ordenamiento del territorio.

Se puntualiza en los conceptos de espacio y territorio como categorías de análisis desde la geografía y sus aportes a la planificación y ordenamiento del territorio, como preámbulo para describir la forma como estos son concebidos en Costa Rica desde las instituciones públicas y el marco jurídico que los acuerpan.

También se describen los factores que influyen en los largos procesos de elaboración y aprobación de los planes reguladores en Costa Rica, donde, tanto en la planificación como en el ordenamiento del territorio, la mayoría de las veces la realidad de la inacción supera las expectativas para los actores sociales o agentes institucionales que lo enfrentan. Entre tantas vicisitudes, se enmarcan las de carácter técnico, administrativo, legal, y los intereses políticos, muchas veces guiadas por los modelos de crecimiento económico, en detrimento de la sustentabilidad ambiental.

\section{Algunos elementos teóricos del ordenamiento del territorio}

El Ordenamiento del Territorio es un proceso dirigido a organizar su uso y ocupación, pero su basamento se halla en el objeto de estudio de la geografía: el espacio, como categoría de análisis y objeto de estudio de la geografía. No 
se podría avanzar la discusión sobre el ordenamiento del territorio sin definir previamente el espacio:

Para Santos (1990, p. 138) el espacio es:

Un conjunto de formas representativas de las relaciones sociales del pasado y del presente, y por una estructura representada por las relaciones sociales que ocurren ante nuestros ojos y que se manifiestan por medio de los procesos y las funciones. Es espacio es, entonces, un verdadero campo de fuerzas cuya aceleración es desigual. Esta es la razón de que la evolución espacial no se realice de forma idéntica en todos los lugares.

Producto de estas fuerzas, se transforma la naturaleza y se produce el espacio y su apropiación, por sí mismo, este, también las condiciona. Es así como los distintos grupos y clases sociales compiten de manera desigual o injusta por su ocupación, este espacio representará una configuración en la que se dará la apropiación de objetos naturales (tierras, manantiales, bosques y otros) y los sociales-artificiales (infraestructuras, monumentos, espacios públicos, edificios, entre otros). Aquellas clases sociales que ostenten el poder económico y casi siempre el político, podrá apropiarse de aquellos lugares o áreas del espacio que aseguren la producción o consumo de bienes y servicios. Para estas clases sociales, el espacio pasa a convertirse en una mercancía; para otros grupos y clases sociales como: los sectores populares o en condiciones de pobreza, este será un bien alcanzable en tanto su capacidad de consumirlo. En el modo de producción capitalista, cuando se produce la apropiación del espacio por los distintos grupos y clases sociales, este adquiere finalmente su esencia mercantil: un valor de uso y un valor cambio.

Santos (1990, p. 146) lo define también como un hecho social, que presenta la condición de hecho histórico y a la vez productor y producto; determinado; un revelador que permite ser descifrado por los mismos a los que revela; y al mismo tiempo, cuando, adquiere un significado auténtico, atribuye un sentido a otras cosas. Según esta acepción, el espacio es un hecho social, un factor social y una instancia social.

El espacio tiene historicidad, un contexto histórico, en el que se han establecido relaciones sociales de producción, que transforman la naturaleza, lo producen y reproducen. Es así que el espacio se crea y configura a partir de un 
modo de producción, de las relaciones sociales de producción. El espacio debe considerarse como el conjunto indisociable del que participan, por un lado, cierta disposición de objetos geográficos, objetos naturales y objetos sociales, y por otro, la vida que los llena y anima, la sociedad en movimiento. El contenido (de la sociedad) no es independiente de la forma (los objetos geográficos): cada forma encierra un conjunto de formas, que contienen fracciones de la sociedad en movimiento. Las formas, pues, tienen un papel en la realización social (Santos, 1996, p. 28).

Las fracciones de esa sociedad, pueden verse en la configuración del espacio, de extraña morfología o dividido como un plato roto o archipiélagos, donde cada fragmento representa un paisaje o escenario, llámesele como se le llame, representa la separación de clases y grupos sociales, y por tanto; de los usos de la tierra, desde los amurallamientos de urbanizaciones lujosas o desde los guetos y los asentamientos en condiciones de pobreza, que no pueden permitirse su compra.

Soja (2014, pp. 53-4) conduce a la filosofía de la búsqueda de la justicia espacial en contextos socialmente producidos, sin importar las múltiples escalas, como lo es la ciudad, la cual debería ser ".... un objetivo político vital pero no es una tarea sencilla de alcanzar, ya que está llena de fuerzas compensatorias destinadas a mantener geografias existentes de privilegio y poder". El autor expone que la mayor parte de la población mundial, hoy es urbana, por tanto, contextualizar la (in) justicia espacial requiere esencialmente localizarla en las condiciones específicas de la vida urbana y en las luchas colectivas para alcanzar un acceso más equitativo de todos en las luchas colectivas, para alcanzar un acceso más equitativo de todos los residentes sociales y a las ventajas que proporciona la ciudad (Soja, 2014, p. 81).

La ciudad como espacio y campo de fuerzas de relaciones sociales, producen una lógica de organización y ocupación, un ejemplo en Costa Rica es la Gran Área Metropolitana (GAM) y su fragmentación en cuatro espacios menores llamados áreas metropolitanas: San José, Alajuela, Heredia y Cartago. Otro ejemplo son los espacios costeros, de inexorable y continua urbanización y que también se fragmentan creando nuevos espacios urbanos. El espacio por ser dinámico, se transforma y presenta configuraciones propias, es decir, cómo se estructuran los objetos del espacio, por ejemplo, la infraestructura vial de carácter radial, que a su vez favoreció el fenómeno de la conurbación costera y sus ciudades difusas. Pero no solo los espacios costeros se urbanizan merced de 
los intereses financieros locales, subsumidos también por los grandes capitales transnacionales del turismo; los espacios costeros y litorales otrora agrarios, sucumben y a las presiones de los capitales inmobiliarios que continúan su avance inexorable, la tierra se convierte en suelo urbanizable, ante el desprecio y banalización del paisaje natural y cultural y de sus habitantes nativos.

Desde los años 1970, Lefebrvre (1978, p. 89) advertía una realidad para los países industrializados, que hoy se hace evidente en Costa Rica sin haber llegado ni a la industrialización, ni a la modernización; asimismo condición propia de los países latinoamericanos.

Como quiera que fuese, la ciudad en expansión ataca al campo, lo corroe, lo disuelve [...] La vida urbana penetra en la vida campesina desposeyéndola de sus elementos tradicionales; artesanado, pequeños centros desaparecen a beneficio de los centros urbanos (comerciales e industriales, retículos de distribución, centros de decisión, etc.). Los pueblos se ruralizan perdiendo lo especifico campesino. Adaptan su marcha a la de la ciudad pero resistiendo o replegándose a veces ferozmente en sí mismos.

David Harvey entrevistado por Rendueles y del Olmo (2009, p. 116), aclara que durante mucho tiempo las ciudades han sido sumideros para la inversión. Esta situación tiene distintas consecuencias: en primer lugar, la forma espacial es constantemente remodelada de acuerdo con los dictados de la acumulación y, en segundo lugar, se emprenden proyectos de reinversión en todos aquellos espacios urbanos ya existentes que tengan una baja rentabilidad (por ejemplo, construyendo instalaciones culturales, estadios de futbol, etc.). Muy a menudo, estos procesos tienen lugar con perjuicio de los mismos vecinos. De acuerdo con Harvey, en la coyuntura actual, el derecho a la propiedad privada y la tasa de beneficio dominan sobre cualquier otro tipo de derechos y esos derechos están consagrados en la Declaración de las Naciones Unidas. Pero también debemos darnos cuenta de que los trabajadores y los vecinos de los barrios luchan por sus derechos y en contra de la injusticia; eliminar todo esto de la política sería una locura.

La justicia espacial debería ser una política de Estado permanentemente revisada, y proyectada a las necesidades de la población, en sus distintas escalas y en la búsqueda del equilibrio ante el crecimiento urbano expansivo, 
depredador de los ecosistemas en su avance por la especulación de la tierra, sin precedentes. Desde esta realidad conviene a continuación, debatir acerca de cómo transformar el espacio, planificarlo desde las políticas públicas y desde los distintos actores sociales: gubernamentales, sectoriales y la población civil.

\section{¿El espacio o el territorio?}

Existe una amplia literatura acerca del concepto teórico de territorio, con tantos enfoques como sus autores y sus respectivas disciplinas o ciencias, tan variadas que incluyen análisis epistemológicos, metodológicos y operativos. Para la geografía el concepto de territorio es fundamental, porque constituye la apropiación del espacio. Blanco (2007, p. 42) manifiesta que: "El territorio tiende a la proyección sobre un espacio dado de las estructuras específicas de un grupo humano, que incluyen el modo de división y de gestión del espacio, el ordenamiento de ese espacio". El autor comparte su definición con Santos (1990) y Silveira (2004), al considerar que la apropiación y transformación de un espacio por parte de una sociedad implica la construcción de un territorio, su uso, su conversión, en un "territorio usado".

Para Bozzano (2004, p. 29) el territorio es la naturaleza, la sociedad y las articulaciones juntas, donde cada proceso adaptará una espacialidad particular. Manifiesta que: un concepto complejo como el de territorio debería barrer todas las instancias metodológicas con la misma exhaustividad, por lo que su definición debería ser una tarea interdisciplinar. Siguiendo a Bozzano (2012, p. 3), este aclara que para explicar cualquier territorio se requiere la presencia y articulación de los siguientes ejes de análisis:

Será necesario en alguna medida indagar, conocer y entender cada medio geográfico, lo natural y lo artificial hibridado en técnicas (1), sus sistemas de objetos y sus sistemas de acciones más significativos (2), sus principales acontecimientos en proceso en tiempo y espacio (3) y la articulación entre lo local, lo meso y lo global que con sus verticalidades y horizontalidades entreteje el poder en cada territorio (4), todas ellas encarnadas por actores públicos, privados y ciudadanos que en sus aconteceres homólogos, jerárquicos y complementarios producen cooperación y conflicto (5). 
En el prefacio del libro: Por una geografía de las territorialidades y las temporalidades. Una concepción multidimensional orientada a la cooperación y el desarrollo territorial de Saquet, M.A. (2015, p. 8) Raffestin resume de manera brillante el concepto de territorio; en cuanto producto y creación, hoy un concepto esencial, una vez que las sociedades, en grados distintos y con intensidades variables, los modifican, hasta destruirlos, el espacio y las propias condiciones de vida sobre la Tierra. El territorio es el instrumento por medio del cual los seres humanos, las comunidades, las sociedades toman posesión del mundo y también lo transforman y destruyen poco a poco, si no se previenen de ello. El estudio del territorio a partir de esa perspectiva apenas ha comenzado. Basta imaginar la ciudad, la villa, la metrópolis, territorios por excelencia, para que surjan todo tipo de problemas a enfrentar.

Enfrentar los problemas de los territorios conduce a su ordenación, también llamado ordenamiento del territorio.

\section{El Ordenamiento del territorio, ¿qué es?}

La construcción del concepto de ordenamiento del territorio (OT) tiene sus inicios en el siglo XIX, a partir de las políticas higienistas en Reino Unido y después de la II guerra mundial en Europa, asumido por la administración pública, así se sentaron las bases para las políticas públicas de planificación. Teóricamente, el OT se debate continuamente, concepto de larga data en el continente europeo, que desde el primer tercio del siglo XX, se reviste de gran importancia principalmente para los urbanistas.

Según Cabrales (2006, p. 601) hasta el siglo XX los asuntos dominantes por resolver en el OT fueron:

a. El establecimiento de límites al crecimiento de las ciudades y la descentralización

b. La instrumentación del zoning o zonificación.

c. La consideración de la ciudad como agregado de unidades de vecindad.

d. La región como ámbito de planificación física y alternativa a las metrópolis. 
Sin duda, los asuntos expuestos por Cabrales tienen que ver con la creación ciudades lineales y ciudades jardín (ventajas del campo en la ciudad) en Europa, las cuales representaban morfologías de baja densidad, que reflejaban el modelo de consumo capitalista y entre ésta el de la tierra. Esquema reproducido rápidamente en Estados Unidos y posteriormente en los países latinoamericanos hasta hoy.

Siguiendo la línea de Cabrales, es comprensible que una de las definiciones sobre OT más reconocidas sea la Carta Europea de Ordenación del Territorio (CEOT): "Es a la vez una disciplina científica, una técnica administrativa y una política concebida como un enfoque interdisciplinario y global cuyo objetivo es un desarrollo equilibrado de las regiones y la organización física del espacio según un concepto rector" (CEOT, 1983, p. 2).

De acuerdo con la definición propuesta, la OT debe ser democrática, funcional, multidisciplinar y prospectiva. Con la consideración de la existencia de numerosos poderes de decisión individual e institucional, que todo estudio prospectivo conlleva un carácter aleatorio, las limitaciones del mercado, las peculiaridades de los sistemas administrativos, la diversidad de condiciones socioeconómicas y ambientales.

Los planteamientos de la CEOT se refieren al desarrollo socioeconómico equilibrado en todas las escalas (local, regional, nacional y continental), la mejora de la "calidad de vida", la gestión responsable de los recursos naturales, la protección del ambiente y la utilización racional del territorio. Zoido (1998, p. 20) argumenta que tal definición no es clara conceptualmente:

Confunde los resultados con el instrumento al definir la ordenación del territorio como 'la expresión espacial de la política económica, social, cultural y ecológica de toda sociedad'; y complica más las cosas al añadir que es 'a la vez una disciplina científica, una técnica administrativa y una política' [...] la ordenación del territorio es esencialmente una función pública, una política compleja y de reciente y todavía escasa implantación, que puede y debe apoyarse sobre instrumentos jurídicos (convenios internacionales, leyes, decretos), sobre prácticas administrativas y principios consolidados (planificación, participación, etc.) y en diferentes conocimientos científicos, en aportaciones necesariamente pluridisciplinares (aspecto que sí recoge la CEOT), entre las que cabe un papel propio y relevante a la geografía. 
Este autor destaca que en tanto que función pública o política, la ordenación el OT es un instrumento, no un fin en sí mismo, un medio al servicio de objetivos generales como el uso adecuado de los recursos, el desarrollo, y el bienestar de los ciudadanos.

Massiris (2005, p. 17) argumenta que el OT es un orden territorial resultante de acciones económicas, tanto públicas como privadas, y de políticas públicas sectoriales, como una política para inducir cambios de dicho orden. Se trata de un proceso de carácter técnico-político-administrativo, para configurar, en el largo plazo, una organización del uso y ocupación del territorio, acorde con sus potencialidades y limitaciones, con las expectativas y las aspiraciones de la población y con los objetivos del desarrollo; además, propone cinco puntos centrales para el OT como política pública:

- Se trata de una política de Estado

- Es una política de largo plazo

- Es un instrumento de planificación

- Debe conciliar el proceso de desarrollo económico con la forma de ocupación territorial a la que aspira

- Y como fin último elevar el nivel de vida de la población.

Siguiendo los puntos expuestos por Massiris, es de vital importancia cuestionar la forma como se imposibilita el rol del Estado ante las fuerzas ejercidas por la globalización cuya lógica se impone sobre la vida socioeconómica y política.

Santos (2004, p. 83) manifiesta que estas lógicas tienen que ver con el dinero de las empresas que además de ser responsables de la producción, son también agentes financieros. En territorios empobrecidos por ejemplo, las transnacionales son capaces de influenciar su uso, es así que “... el contenido del territorio escapa a toda a regulación interna, objeto de una permanente inestabilidad, de la cual los diversos agentes sólo constituyen testigos pasivos". Ante la realidad descrita, las conceptualizaciones teóricas sobre el OT podrían permanecer como idealizaciones, pues como indica Santos, se genera ingobernabilidad en virtud de los efectos sobre la vida económica, pero también sobre la vida administrativa, además al considerar la pérdida de identidad a favor de formas de regulación extrañas al sentido local de la vida. 
Llegado a este punto, la orientación de ocupación y manejo del territorio, debe ser competencia del Estado y desde los gobiernos locales, desde la política pública como ordenanza y el marco legal que la refuerza. A partir de esta premisa puede definirse como:

La definición de lineamientos sobre el territorio bajo una facultad normativa consensuada con los involucrados, ya sean beneficiados o afectados. Es ponerse de acuerdo sobre el uso y ocupación del territorio para mejorar la calidad de vida de la población en el mediano y largo plazo. Cuando una municipalidad promueve el OT debe tener una visión integral y una planificación para el desarrollo social, económico y productivo (AECIDAMHON, 2010, p. 9).

En Costa Rica el OT suele considerarse como un rol de las municipalidades, que deben respetar el marco institucional y jurídico vigente, este último establece quiénes son sus responsables en la formulación de planes de OT. El Instituto de vivienda y urbanismo (INVU) lo define como:

\begin{abstract}
Proceso administrativo, político y participativo, basado en un soporte legal, técnico y científico, a través del cual el Estado, los gobiernos municipales y demás entes públicos gestionan, regulan, orientan y promueven diversas acciones en el territorio para el cumplimiento de sus fines. Posibilita armonizar el bienestar de la población, con el aprovechamiento y conservación de los recursos ambientales, así como ubicar de forma óptima las actividades económicas, productivas, los asentamientos humanos, las áreas públicas, los servicios públicos, entre otras. Sirve de guía para el uso sostenible de los elementos del ambiente. Hace posible equilibrar el desarrollo sostenible de las diferentes zonas del país. Promueve la participación ciudadana en la planificación de los territorios (INVU, 2018, p. 7).
\end{abstract}

Esta definición aunque se refiere al desarrollo sostenible debería profundizar la importancia del tema ambiental que destaca el Estado costarricense, y que ha propuesto en su Política Nacional de Ordenamiento Territorial (PNOT 2012-2040), la cual lo refiere como:

Un modelo de desarrollo que procura la preservación del equilibrio ecológico, social y económico, sin comprometer la satisfacción de las necesidades de las generaciones futuras. El desarrollo del territorio nacional 
debe respetar a un modelo sostenible, que permita a las regiones del país aprovechar las diferentes ventajas estratégicas, priorizando el desarrollo a largo plazo y generando asentamientos humanos, en los cuales los habitantes puedan gozar de un ambiente sano y ecológicamente equilibrado. Y entre sus ejes estructurales destaca el manejo de cuencas y recurso hídrico, el uso y manejo de suelos, carbono neutral y educación ambiental (PNOT, 2013, pp. 12-19).

\section{El plan regulador como modelo de OT en Costa Rica}

El Manual de Planes Reguladores como Instrumento de Ordenamiento Territorial, establece que referente a la integración de la variable ambiental o de impacto ambiental, debe considerarse la promulgación de normativa y votos de la Sala Constitucional en materia ambiental, que indica las respectivas competencias de la Secretaría Técnica Nacional Ambiental (SETENA) y el Servicio Nacional de Aguas Subterráneas, Riego y Avenamiento (SENARA) en materia ambiental, con relación a los Planes Reguladores.

Gómez, D. y Gómez, A. (2012, p. 34) especifican que el OT también se aplica como enfoque y metodología para planificar el desarrollo sostenible, en cuanto identifica las actividades que posibilitan el desarrollo, las distribuye en el espacio de acuerdo con la vocación natural del medio físico y con las relaciones de sinergia, complementariedad, compatibilidad e incompatibilidad que se dan entre ellas, regula su funcionamiento y atiende a todas las facetas social, económica y ambiental- de la calidad de vida. Con frecuencia se establece un plan de ordenamiento territorial o el plan regulador como "modelo" de OT.

En Costa Rica el plan regulador es definido como:

Instrumento de planificación y gestión de nivel local, en el que se define en un conjunto de planos, mapas, reglamentos y cualquier otro documento, gráfico o suplemento, la política de desarrollo urbano y los planes de distribución de la población, usos del suelo, vías de circulación, servicios públicos, facilidades comunales, construcción, renovación urbana, entre otros (INVU, 2018, p. 7).

Como se ha mencionado en párrafos anteriores, el fenómeno de la urbanización con escaso urbanismo en Costa Rica es galopante, se reproduce en los espacios rurales y costeros, y con ello la perdida de suelos, al tiempo que 
se comprometen otros recursos valiosos como el recurso hídrico, los suelos, las coberturas vegetales, entre otros; asimismo, tiene sus efectos en las poblaciones vulnerables y empobrecidas. Ante esta situación las municipalidades requieren la formulación de sus propios planes reguladores; pero no son suficientes si no existe una gestión sistemática de sus recursos económicos y humanos.

La gestión es un proceso dirigido a materializar el ordenamiento o la planificación del territorio, esto es fundamental para responder a las expectativas de la población o actores y agentes sociales. La fase de gestión en realidad es parte de la misma planificación y programación; pero se distingue para facilitar la implementación. Muchos planes no se implementarían a menos que se gestionen los recursos y medios para lograr los objetos de los planes.

\section{¿El ordenamiento o la planificación del territorio?}

Hay que añadir que existe confusión entre los conceptos de ordenamiento y planificación del territorio, porque las diferencias teóricas parecen ser pocas y suelen usarse en la literatura indistintamente. El ordenamiento es propositivo, corresponde a la acción; pero la planificación del territorio supone el proceso de preparación de un conjunto de decisiones tomadas, normalmente por o para la administración pública, con objeto de actuar en el futuro (Barragán, 1994, p. 112).

El instituto Geográfico Agustín Codazzi (1998, p. 17) plantea:

El ordenamiento territorial es un proceso mediante el cual se orienta la ocupación y utilización del territorio y se dispone cómo mejorar la ubicación en el espacio geográfico de los asentamientos (población y vivienda, la infraestructura física (las vías, servicios públicos, las construcciones) y las actividades socioecómicas. Esto quiere decir sencillamente que con el ordenamiento se tiene: ...un lugar para cada cosa y cada cosa en su lugar.

\section{De la suma de procedimientos del marco jurídico administrativo, político y técnico, para la elaboración y aprobación de planes reguladores en Costa Rica}

La planificación urbana a escala nacional es competencia del Instituto de vivienda y urbanismo (INVU), y el ordenamiento del territorio (OT) es función 
de los gobiernos locales, según estipula la Ley de planificación urbana n. ${ }^{\circ} 4.240$ del año 1968, de elaborar y ejecutar sus planes regulares.

La Ley orgánica del ambiente n. ${ }^{\circ} 7.554$ del año 1995 capítulo IV, art. 28 sobre políticas de ordenamiento territorial, establece que es función del Estado, las municipalidades y los demás entes públicos, definir y ejecutar políticas nacionales de ordenamiento territorial, tendientes a regular y promover los asentamientos humanos y las actividades económicas y sociales de la población, así como el desarrollo físico-espacial, con el fin de lograr la armonía entre mayor bienestar de la población, el aprovechamiento de los recursos naturales y la conservación del ambiente. Igualmente los artículos 29, 30 y 31, se refieren a los fines, a los Criterios para el ordenamiento y al Desarrollo urbanístico.

La Constitución política en el título XII: desde los artículos 168 al 175 se refieren al régimen municipal; fundamentalmente el artículo 169, establece que la administración de los intereses y servicios locales en cada cantón, estará a cargo del Gobierno municipal, formado de un cuerpo deliberante, integrado por regidores municipales de elección popular, y de un funcionario ejecutivo que designará la ley.

Cualquier municipio que el ordenamiento de su territorio, debe tomar un acuerdo desde el Concejo municipal, referente a la necesidad de elaboración de un plan regulador.

Además, para la elaboración y aprobación de un plan regulador se debe crear una junta o comisión local de planificación para la elaboración de el plan regulador, esto según el artículo 60 de la Ley n. ${ }^{\circ}$ 4.240. Esta será conformada por no menos de tres ni más de siete miembros, los cuales desempeñarán sus cargos sin goce de salario. Asimismo, será integrada por regidores, funcionarios de la planta administrativa y vecinos interesados.

Posteriormente, aunque el municipio decidiese elaborar su propio plan regulador con profesionales propios, posiblemente deba suscribir contratos con consultores especializados en algunas áreas del conocimiento para la redacción del plan regulador, la contratación de los servicios puede realizarse de manera directa o por licitación. En Costa Rica existen empresas consultoras nacionales y así como representaciones internacionales que ofertan el servicio; igualmente, el INVU como ente rector puede realizar el estudio bajo convenio (art. 61, Ley 4.240), además, pueden participar ONGs. Las universidades públicas también elaboran los estudios de planes reguladores, por ejemplo: ProDUS-UCR, de la 
Universidad de Costa Rica y la Escuela de Ciencias geográficas de la Universidad Nacional (ECG-UNA).

Las municipalidades con recursos propios pueden financiar sus planes reguladores, ejemplo de estos municipios son los de Atenas, Belén, Escazú, Esparza y San José. De esta forma, si las municipalidades cuentan con suficientes recursos económicos y con funcionarios especialistas, pueden elaborar sus planes reguladores, como es el caso de la municipalidad del cantón de Belén de la provincia de Heredia.

Los costos financieros del proyecto, pueden ser estimados mediante asesorías de entes públicos como el Instituto de Fomento y Asesoría Municipal (IFAM) o la ECG-UNA.

Existen experiencias de subvención por medio de instituciones públicas $\mathrm{u}$ organizaciones internacionales que invierten en el financiamiento para la elaboración de planes reguladores, como:

- El Ministerio de planificación nacional y política económica (MIDEPLAN) por medio del fondo de Pre inversión no reembolsable, que apoya al sector municipal en materia de planificación y desarrollo, con enfoque territorial. Por medio de este financiamiento, se elaboran estudios técnicos, preliminares o de pre-factibilidad, como el caso de los planes reguladores (MIDEPLAN, 2013).

$\sqrt{ }$ Destacan los de Poás y Siquirres, financiado bajo el denominado Convenio de transferencia no reembolsable entre del Fondo de pre inversión MIDEPLAN.

- El IFAM por medio de empréstitos.

- Organismos internacionales han financiado proyectos a escala regional, por ejemplo:

$\sqrt{ }$ La Unión europea cofinanciadora del Plan Regional Urbano de la Gran Área metropolitana (PRUGAM, 2008 -2030).

$\sqrt{ }$ La Agencia española de cooperación internacional para el desarrollo, por medio de su instrumento de la cooperación técnica y financiera: 
La Fundación para el desarrollo local y el fortalecimiento municipal e institucional de Centroamérica y el Caribe (Fundación DEMUCA), y Río Frío-INBIO financió la elaboración del Plan Regulador de la Zona Norte (que comprende los cantones de Guatuso, Upala y los Chiles), proyecto cuyos estudios fueron realizados por la ECG-UNA.

Una vez el gobierno local cuente con los recursos económicos para financiar el proyecto, se inicia el proceso de elaboración.

La preparación de un plan regulador da inicio con la obtención de la Variable ambiental, cuya aprobación será otorgada por la Secretaria técnica nacional ambiental (SETENA), según el Anexo I del decreto 32.967-MINAE de 2006: Procedimiento técnico para la introducción de la variable ambiental en los planes reguladores u otra planificación de uso del suelo, en el numeral 2.1.1 se establece:

La finalidad primordial del procedimiento es aportar los lineamientos técnicos principales y básicos que deberá cumplir la municipalidad, autoridad correspondiente o usuario del instrumento, para incorporar la variable de impacto ambiental o variable ambiental en la planificación del uso del suelo de su territorio jurisdiccional o de interés, así como indicar los lineamientos técnicos que seguirá la SETENA para revisar y evaluar dicha introducción de variable ambiental, a fin de otorgar en definitiva, y en caso de que se cumplan los procedimientos definidos, la Viabilidad (Licencia) Ambiental a la propuesta (MINAE, 2006, p. 2).

Antes de especificar la metodología de la variable ambiental, hay que aclarar que no se trata de un primer decreto u ordenanza, pues ya desde el año 2002 la Sala constitucional, resolvió que todos los planes reguladores de previo a su aprobación, debían presentar una evaluación de impacto ambiental; y dos años después: bajo decreto ejecutivo n.o 31.849-MINAE-SALUD-MOPTMAG-MEIC (2004) se estableció el Reglamento general de procedimientos de Evaluación de Impacto Ambiental (EIA), el Reglamento de la Evaluación Ambiental Estratégica como proceso aplicado a políticas, planes y programas, y el correspondiente Manual de instrumentos técnicos para el proceso de Evaluación de Impacto Ambiental (Manual de EIA). Persiste el criterio de si era necesario el decreto 32.967-MINAE (2006), asumiendo además el amplio marco legal ambiental existente. 
Retomando la metodología de la introducción de la variable ambiental del decreto 32.967-MINAE, presenta tres etapas:

1. Índices de Fragilidad Ambiental (IFA) correspondientes a cuatro ejes temáticos: la antropoaptitud, bioaptitud, edafoaptitud y geoaptitud. Los IFA son definidos por el Poder ejecutivo y el MINAE:

Como el balance total de carga ambiental de un espacio geográfico dado, que sumarita la condición de aptitud natural del mismo (biótica, gea y de uso potencial del suelo), la condición de carga ambiental inducida, y la capacidad de absorción de la carga ambiental adicional, vinculada a la demanda de recursos.

Dentro de la metodología IFA: la antropoaptitud se refiere a la condición que presenta un espacio geográfico de acuerdo a los distintos usos del suelo que presenta. La bioaptitud que corresponde a los estudios respecto a la condición natural que posee un territorio desde el punto de vista biológico. La edafoaptitud la cual considera la zonificación de usos de acuerdo a las características que posea, su capacidad de uso de la tierra. Y la geoaptitud hace referencia a la condición de estabilidad natural de un territorio, desde el punto de vista de las condiciones del subsuelo y todos aquellos procesos geodinámicos que puedan alterar esa estabilidad

2. Análisis de Alcance Ambiental (AAA). Se evaluá la situación ambiental del uso del suelo, según los distintos efectos acumulativos que va a depender del área de estudio y se proyecta los posibles impactos ambientales que puedan producirse con el uso propuesto. Debe contener

- La valoración de uso actual del suelo referente a la zonificación de fragilidad ambiental identificada.

- Las zonas de sobre uso actual, donde se ha superado la capacidad de carga (fragilidad ambiental) 
- Determinado el sobreuso se establecen las medidas ambientales correctivas, a partir de la enumeración de los principales impactos ambientales.

3. El Reglamento de Desarrollo Sostenible (RDS), para el plan de manejo de uso del suelo. Se realiza a partir del estudio IFA, y el AAA, se establecen los lineamientos de desarrollo; además, debe elaborase un mapa con los usos del suelo propuestos. Para el plan regulador. (MINAE, 2006 p. 1-12).

Cabe aclarar que en el proceso de elaboración y revisión de la Variable Ambiental, antes de llegar a SETENA, se establece por la Sala Constitucional desde el año 2013, un nuevo agente institucional: el Sistema Nacional de Riego y Avenamiento (SENARA), que incide en los términos técnicos y administrativos, al acatar la resolución de la sala IV mediante el voto 8892 2012, en la cual se ratifica que SENARA debe cumplir la resolución del 26 de febrero del 2010, que ordenó que la Matriz de uso del suelo según vulnerabilidad a la contaminación de acuíferos para la protección de del recurso hídrico, es de aplicación en todos los cantones o zonas en donde se cuenta con mapas de vulnerabilidad aprobados o confeccionados por el SENARA, y formar parte de las demás instituciones que tienen injerencia directa sobre la aprobación de los planes reguladores entre ellas el Ministerio de Vivienda y Asentamientos Humanos (MIVAH), el INVU, SETENA y el Instituto costarricense de Turismo (ICT).

La resolución de la Sala Constitucional elimina la potestad de la SETENA para la revisión de la evaluación hidrogeológica, con el propósito de que en el IFA integrado, las posibles zonas de alta fragilidad hidrogeológica no fuesen subvaloradas, y evitar la posibilidad de usos no aptos sobre éstas.

Posteriormente SENARA aprobó en acuerdo n. 4.975 (oficio DIGH133-15), la directriz para la elaboración de la Metodología de estudios hidrogeológicos y los términos de referencia para planes reguladores. (LA GACETA: 16 de julio, 2015). Se trata de un instrumento técnico para la protección del recurso hídrico, sobre todo subterráneo, de actividades humanas por medio de la aplicación de criterios del uso del suelo apropiado en función de la vulnerabilidad hidrogeológica y la actividad productiva. 
Una vez revisado y aprobado el estudio hidrogeológico, SENARA lo oficializará, y emitirá un pronunciamiento de aprobación del Estudio del componente hidrogeológico y zonificación propuesta; así como las recomendaciones para el uso del territorio, a considerar en el plan regulador. De no ser aprobado el estudio, y la municipalidad determina continuar el proceso, debe corregir las observaciones realizadas por SENARA. Si el municipio no ha realizado un convenio o contrato transparente en cuanto a costos, y una exhaustiva selección y contratación de los servicios de consultoría de alta calidad, o de profesionales independientes idóneos, podría implicar entre otras cuestiones: recontrataciones de los consultores que elaboraron el estudio o de nuevos especialistas; también podrían generarse costos financieros mayores que no fueron considerados en el presupuesto; igualmente, en la extensión del tiempo programado de finalización del producto.

Avalado el estudio hidrogeológico por SENARA, se integrará a los estudios de la Variable ambiental pendientes (indicados en párrafos anteriores), para que finalmente sean enviados por el municipio a la SETENA, para su revisión y aprobación, y su incorporación a la propuesta del plan regulador. En esta parte también hay que hacer un paréntesis, para indicar que la SETENA, puede archivar el estudio de la variable hidrogeológica, si este no cumple con todos los parámetros indicados en el Manual de instrumentos técnicos para el proceso de evaluación de impacto ambiental (Manual de EIA), por ejemplo, no cumplir con las especificaciones de tablas de orientación para la calificación de variables a considerar e integrar como parte de la aplicación del método IFA del Anexo II del decreto 32.967-MINAE. Nuevamente, el municipio debe estar preparado para recibir las observaciones de SETENA. Como se ha mencionado previamente, lo mejor es realizar contratos y presupuestos previsores, en caso de que haya que ajustar o elaborar nuevas partes del estudio.

La SETENA fijará un plazo para la entrega de la información solicitada, periodo durante el cual se suspenderá el plazo de revisión. En caso que el estudio mantenga significativos problemas de fondo e incumplimiento de los procedimientos señalados en el Manual de instrumentos técnicos, la SETENA fundamentará en un reporte el rechazo del estudio (numerales 7.4.2 y 7.4.3).

Un ejemplo de esta realidad fue la contratación por licitación de dos empresas españolas para realizar los planes reguladores cantonales y costeros de las provincias de Guanacaste y Puntarenas, estas consultoras fueron: Informes y Proyectos Sociedad Anónima (INYPSA), para la elaboración de todos los 
planes reguladores urbanos y Estudios, proyectos y planificación S.A.(EPYPSA) para los planes reguladores costeros. Todos los estudios fueron rechazados por SETENA, porque se argumentó que hubo falencias en la calidad de la información y no se presentaron todas las variables ambientales que establece la normativa del estudio IFA. Los planes reguladores fueron promovidos por el Programa de Regularización de Catastro y Registro, conocido como BIDCatastro. El proyecto tuvo un costo de $\$ 65.000 .000$ financiado por el Banco Interamericano de Desarrollo (BID), así como una contrapartida del gobierno por \$27.000.000 que incluía la elaboración de 26 planes reguladores, entre ellos el Plan Estratégico Regional de Ordenamiento Territorial (Perot) para Guanacaste.

Hasta el año 2017 solo la municipalidad del cantón de Carrillo en Guanacaste, presenta la aprobación de SETENA y cuenta con el plan regulador de la zona marítimo terrestre aprobado. Ante esta realidad Astorga aduce:

En diversas ocasiones previas hemos advertido de lo grave que significa para el país, que más de 70 planes reguladores cantonales o costeros se encuentren en una especie de 'limbo' tramitológico ante la Secretaría Técnica Nacional Ambiental (SETENA) y luego ante el INVU. Gravedad que no solo tiene que ver con el costo económico que ha significado para el Estado y las municipalidades, sino en especial, por el gran tiempo perdido... (La Extra, 2016).

\section{Hacia la "flexibilización” para la aprobación de los planes reguladores. Entre la viabilidad técnica y política}

El 2 de febrero del año 2015, el gobierno de Luis Guillermo Solís Rivera publica en el diario oficial La Gaceta el Decreto Ejecutivo n. 38.782 -MINAEMAG-MIVAH-MIDEPLAN; en el mismo se establece el reglamento para agilizar las acciones de revisión y aprobación de planes reguladores locales y costeros.

El decreto estableció un plazo de para la creación de una Comisión interinstitucional para agilizar las acciones de revisión y aprobación de planes reguladores locales. Debía estar conformada por un represente de las siguientes instituciones públicas: Ministerio de agricultura y ganadería (MAG), MIVAH, MINAE, MIDEPLAN, SETENA, SENARA y el INVU. 
Parte de los considerandos son:

IV. Que esta administración es consciente de la necesidad de una adecuada evaluación ambiental estratégica en los procesos de elaboración de planes reguladores, a través de los cuales se garantice la protección del medio ambiente y especialmente del recurso hídrico, de acuerdo con el análisis e incorporación de diversas variables establecidas para estos efectos.

Asimismo, se considera:

VI. - Que esta Administración está heredando una severa parálisis e inseguridad jurídica en algunas etapas del proceso de revisión y aprobación de planes reguladores, lo cual está generando que una gran parte del territorio nacional, no cuente con instrumentos de ordenamiento territorial vigentes, lo anterior pese a que muchos de ellos se encuentran formulados por parte de los gobiernos locales respectivos (MINAE-MAG-MIVAH-MIDEPLAN, 2015, p. 1).

Entre los artículos del decreto destaca el número cinco, donde subraya apoyar a SENARA en la construcción del procedimiento efectivo para la revisión de los estudios hidrogeológicos y también apoyar a SETENA en la definición de procedimientos transitorios para la evaluación ambiental de los planes reguladores locales y costeros, de conformidad con la información existente y disponible a escala nacional. De igual modo, se obliga a preparar un decreto ejecutivo por los jerarcas de las instituciones correspondientes, para establecer las acciones para la revisión y aprobación de planes reguladores locales y costeros.

Para la discusión y elaboración previa del decreto la Unión Nacional de Gobiernos Locales (UNGL) no fue convocada a incorporar un representante de los gobiernos locales en la Comisión interinstitucional, por tal motivo, una vez conocido el decreto, se pronunció con el envío de una solicitud formal a MIDEPLAN. Posteriormente adujeron no recibir respuesta.

Karen Porras como directora ejecutiva de la UNGL declaró: 


\begin{abstract}
Queremos participar activamente en este proceso de construcción de soluciones, tal como lo hemos venido haciendo desde el inicio de la administración Solís Rivera, cuando se han abierto canales de comunicación y coordinación con las instituciones públicas rectoras en la materia. Estamos haciendo este llamado al Gobierno, con el cual venimos coordinando acciones para avanzar en diferentes temas de interés del Régimen Municipal, entre los que destacan los planes reguladores. Queremos aportar y lograr un verdadero avance que le permita a las municipalidades aprobar sus planes reguladores sin tanta burocracia estatal (La Extra, 2015).
\end{abstract}

El 20 de abril de 2015 el gobierno sometió a consulta pública el "Reglamento del período transitorio para la revisión y aprobación de los planes reguladores" para que la ciudadanía y los otros sectores opinaran sobre el tema para ordenar y dar herramientas para la agilización en la revisión y aprobación de los planes reguladores.

En Decreto ejecutivo n. ${ }^{\circ}$ 39.150- MINAE-MAG-MIVAH-PLAN-TUR del 03 de setiembre del 2015, nuevamente el poder ejecutivo trata de agilizar los procesos de elaboración de planes reguladores mediante el mencionado Reglamento de la transición para la revisión y aprobación de Planes Reguladores. En el decreto se estable un periodo de cinco años a partir de la fecha de vigencia. Ahora SETENA revisaría y aprobaría la viabilidad ambiental de los planes reguladores, en los cuales la vulnerabilidad hidrogeológica podría ser examinada con la metodología estipulada por SETENA, en el Decreto n. ${ }^{\circ}$ 32.967-MINAE del año 2006, sin necesidad de ser revisada y aprobada previamente por SENARA; igualmente se permitiría utilizar un equipo multidisciplinario de profesionales inscritos en SETENA, que no corresponde a lo establecido en el decreto $\mathrm{N}^{\circ} 32967$, el cuál especifica cuáles deben ser estos profesionales según los temas de investigación. El decreto excluye once cantones, algunos de estos pertenecen al área norte de la provincia de Heredia, por ser una zona de recarga acuífera y muy amenazada por el crecimiento urbano.

El decreto n. ${ }^{\circ} 39.150$ no fue bien recibido por grupos ambientalistas y profesionales académicos, porque "atropella" al Decreto n. 32.967-MINAE del año 2006, se aduce que se trata de una irresponsabilidad política, es así que fue impugnado por el geólogo ambiental Allan Astorga Gättgens y el abogado ambientalista Álvaro Sagot Rodríguez, para que se declaren inconstitucionales los artículos 1, 2, 3, 4, 16, 21, 22, 23 inciso c), 24 inciso c) 31, por su carácter 
regresivo que desprotege el ambiente e irrespeta procedimientos prestablecidos y normas técnicas y legales vigentes. De acuerdo con las observaciones emitidas por Astorga y Sagot:

[...] Las herramientas de agilización permiten a las municipalidades apartarse de la normativa existente y acogerse a excepciones durante el periodo de transición, todo ello en perjuicio de la vulnerabilidad hidrogeológica y, en general, del ambiente, al obviarse aspectos técnicos vinculados a la protección de los recursos hídricos subterráneos, a la gestión del riesgo preventivo en materia de amenazas naturales y a la capacidad de uso del suelo. El procedimiento permite que durante la vigencia de las condiciones de excepción, se aprueben y entren en vigencia planes reguladores que no cuenten con información completa en los extremos señalados (Sala Constitucional, 2015).

Otra postura sobre el decreto entre especialistas del OT, es que el gobierno de Luis Guillermo Solís Rivera, aspiró avanzar ante los engorrosos trámites burocráticos de revisión y dar ventaja a los municipios para iniciar con los planes reguladores que tuviesen los estudios, los cuales se podrían mejorar en el corto plazo, pero tener algo con qué empezar para ordenar los territorios.

Ante los procedimientos de elaboración de los estudios requeridos por las instituciones mencionadas, es reconocible la complejidad de las metodologías tanto de la Variable ambiental de SETENA, como de la vulnerabilidad hidrogeológica de SENARA; cuyas dificultades no solo se hayan en la contratación de numerosos consultores y financiamientos onerosos, también por las especificaciones técnicas para obtener los parámetros de indicadores e índices, en muchas ocasiones complicados y difíciles de recabar, ante la carencia de información, o con frecuencia desactualizada, incompleta o dispersa en instituciones que también tienen injerencia en el OT, como la Comisión Nacional de Prevención de Riesgos y Atención de Emergencias. (CNE), el Sistema Nacional de Áreas de Conservación (SINAC), que a su vez es un órgano adscrito del MINAE, el Ministerio de Agricultura y Ganadería (MAG) y el Instituto Nacional de Innovación y Transferencia en Tecnología Agropecuaria (INTA).

Las argumentaciones expuestas dieron lugar a que en mayo de 2016 la Asociación de la cámara de la construcción, y otras diez cámaras entre estas: de hoteleros, de industrias, de transporte de carga y textiles, unidas a un grupo 
de municipalidades, denunciaran a SENARA ante el Tribunal Contencioso Administrativo, por la promulgación de la Matriz de criterios de vulnerabilidad hidrogeológica, según el expediente 15-008626-1027-CA (CONCEVERDE, 2016).

Hay que exponer que también SENARA recibe constante presión de grupos económicos y gobiernos locales, porque aducen la frecuente descoordinación entre sus departamentos; asimismo, porque no cuenta con suficiente presupuesto para contratar nuevo personal que agilice la revisión y aprobación de los estudios que recibe. Esta situación fue aceptada por la Ing. Patricia Quirós, exgerente general de la Dirección de investigación y gestión hídrica, que en su informe final de gestión subraya:

La demanda de servicios de las instituciones del país y de los sectores desarrolladores y comunales, ha aumentado en valores que ha provocado problemas en la atención oportuna por parte del SENARA. Además de los problemas que se manifiestan en la capacidad de atender las solicitudes de perforación y dictámenes, lo que se manifiesta en los tiempos de atención que se han ampliado desde 1 mes hasta 6 meses, la demanda en temas como los planes reguladores, investigación hidrogeológica y el aumento importante en procesos comunales que se transforman en conflictos por el uso y acceso del agua, requiere tomar las medidas adecuadas, para contar con los recursos financieros y de personal (Oficio n. ${ }^{\circ}$ DIGH-399-16, 2016, p. 16).

Finalmente en octubre del 2017 se publicó en La Gaceta, el Acuerdo n. 5497 de SENARA, que establece la Matriz Genérica de Protección de Acuíferos, la cual se ajustó con tres tipos de actividad (agropecuaria, urbanística e industrial), a partir de consultas técnicas a las distintos sectores, agentes sociales e instituciones públicas; por tanto, se sustituyó la matriz del año 2006, con el sustento jurídico del Tribunal Contencioso Administrativo y la Sala Constitucional (Voto 8892-2012). Dentro del tema de los planes reguladores, la nueva Matriz también reajustó el procedimiento del Método GOD, concerniente a la Vulnerabilidad Intrínseca a la Contaminación de Acuíferos, sin embargo la metodología corresponde a un modelo internacional con parámetros estandarizados, el cual es de carácter preventivo a la contaminación de las aguas subterráneas. 


\section{Continuación de las etapas de elaboración de los estudios de planes reguladores, una vez aprobada la variable ambiental}

El proceso de elaboración de un plan regulador, debe avanzar en sus distintas etapas, mientras se haya a la espera de la resolución de la Variable ambiental por la SETENA y una vez aprobada, el equipo consultor, concluirá todas las fases correspondientes al plan regulador, en acato de disposiciones del El Manual de Planes Reguladores como Instrumento de Ordenamiento Territorial, del INVU:

- Fase de Análisis y Diagnóstico

- Fase de Pronóstico

- Fase Propositiva

- Fase de Implementación (gestión)

Finalizado el proceso de elaboración del plan regulador, la municipalidad debe previamente a implantarlo según el artículo 17 de la Ley n. ${ }^{\circ}$ 4.240:

1. Convocar a una audiencia pública por medio del Diario oficial y divulgación adicional necesaria con la indicación de local, fecha y hora para conocer del proyecto y de las observaciones verbales o escritas que tengan a bien formular los vecinos o interesados. El señalamiento deberá hacerse con antelación no menor de quince días hábiles;

2. Obtener la aprobación de la Dirección de Urbanismo del INVU, si el proyecto no se hubiere originado en dicha oficina o difiera del que aquélla hubiere propuesto, sin perjuicio de los recursos establecidos en el artículo 13.

3. Acordar su adopción formal, por mayoría absoluta de votos; y

4. Publicar en La Gaceta el aviso de la adopción acordada, con indicación de la fecha a partir de la cual se harán exigibles las correspondientes regulaciones. 


\section{Consideraciones finales}

Ante el creciente interés global por el ordenamiento territorial, se favorece la interpretación del espacio y su expresión como territorio, al tiempo que aumenta el interés entre distintas ciencias y disciplinas, que también buscan aportar al conocimiento y a la práctica territorial; por tanto, resulta un privilegio desde la geografía la profundización de los conceptos teóricos trascendentes como el espacio, el territorio y su planeación, la cual permite definir estrategias de organización de su uso y ocupación; es así, que un proceso de elaboración de planes reguladores es un asunto delicado, porque deben aplicarse instrumentos técnicos que conlleven al aprovechamiento del suelo, que contribuyan a mejorar las condiciones de vida de los habitantes del territorio, sobretodo de las poblaciones empobrecidas poco resilientes a los riesgos de amenazas naturales o antrópicas.

La burocracia en los procesos administrativos de búsqueda de información y aprobación de documentos en el proceso de elaboración de planes reguladores, sumado a las constantes cambios en decretos de los gobiernos de turno y en las directrices de las instituciones públicas, conducen a confusiones y arbitrariedades, donde incluso las entidades públicas son juez y parte, porque algunas de ellas también participan como consultoras en estudios dentro de procesos de OT, como lo son el INVU, ICT o SENARA.

Queda claro que aunque existe una política pública y un marco jurídico que incide en el OT en Costa Rica, se devienen constantes implicaciones legales para lograr consensos sobre el uso del suelo, y se requiere gran capacidad de integración entre los intereses económicos, sociales, políticos e incluso culturales.

\section{Referencias}

AECID-AMHON. Manual de Ordenamiento Territorial. No. 4, Serie Procesos Administrativos de Catastro. Tegucigalpa: Programa Fortalecimiento del Régimen Municipal y Desarrollo Local en Honduras, 2010.

ASAMBLEA CONSTITUYENTE DE COSTA RICA. Constitución Politica de la República de Costa Rica. Disponible en: http://www.costaricaweb.com/general/ constitucion.html. Acceso en: 17 sep. 2016. 
ASAMBLEA LEGISLATIVA DE LA REPÚBLICA DE COSTA RICA. "Ley de Planificación Urbana”. Diario Oficial La Gaceta. San José, nov. 1968. Disponible en: http://www.pgrweb.go.cr/scij/Busqueda/Normativa/Normas/nrm_texto_completo.aspx ?param $1=$ NRTC \&nValor $1=1 \&$ nValor2=35669\&nValor3=80861\&para $\mathrm{m} 2=1 \&$ strTipM=TC\&lResultado=5\&strSim=simp. Con acceso el: 22 oct. 2016.

. “Ley Orgánica del Ambiente”. Diario Oficial La Gaceta. San José, oct. 1995. Disponible en: http://www.oas.org/dsd/fida/laws/legislation/costa_rica/costa_rica_7554.pdf. Con acceso el: 22 oct. 2016.

ASTORGA, A. "Planes reguladores, ProDUS UCR y SETENA: juzgue usted". Diario Extra. San José, abr. 2016. Disponible en: http://www.diarioextra.com/Noticia/ detalle/289827/planes-reguladores,-produs-ucr-y-setena:-juzgue-usted. Con acceso el: 11 ene. 2017.

BARRAGÁN, J. M. Medio ambiente y desarrollo en las áreas litorales. Guia prácticapara la planificación y gestión integradas. Barcelona: Oikus-Tau, 1994.

BLANCO, M. Gestión ambiental: camino al desarrollo sostenible. San José: EUNED, 2007.

BOZZANO, H. Territorios reales, territorios pensados, territorios posibles: aportes para una teoría territorial del ambiente. Espacio: Buenos Aires, 2004.

. El territorio usado en Milton Santos y la inteligencia territorial en el GDRI INTI: iniciativas y perspectivas. Disponible en: http://www.memoria.fahce.unlp.edu.ar/ trab_eventos/ev.2636/ev.2636.pdf. Acceso en: 10 ene. 2017.

CABRALES, L. P. Geografía y ordenamiento territorial: Tratado de geografía humana. Barcelona: Anthropos, 2006.

CONCEVERDE. Cámaras de Empresarios Atacan Instrumento Técnico de Senara. Disponible en: http://conceverde.blogspot.com/2016/05/camaras-de-empresarios-atacan.html. Acceso en: 07 ene. 2017.

CONSACA. "UNA por la Madre Tierra. Programación Anual de temas de coyuntura”. Disponible en: http://www.campus.una.ac.cr/ediciones/2016/junio/2016junio_ agenda.pdf. Acceso en: 15 ene. 2017. 
CONSEJO DE EUROPA. Carta europea de Ordenación del Territorio. Torremolinos, España, 1983.

GÓMEZ, D. y GÓMEZ, A. “Ordenamiento territorial: una aproximación conceptual y su aplicación al cantón Cuenca - Ecuador”. Revista de la Universidad del Azuy, n. 57, pp. 29-88, Ecuador, 2012.

GTZ-KFW-KFW. Guia simplificada para la elaboración del plan de ordenamiento territorial municipal. Bogotá: Instituto Geográfico Agustín Codazzi, 1998.

GUDIÑO, M. Responsabilidad social de la universidad en cuanto al ordenamiento territorial. Disponible en: http://www.unidiversidad.com.ar/responsabilidad-social-de-la-universidad-en-cuanto-al-Ordenamiento-territorial. Acceso en: 23 feb. 2017.

INSTITUTO GEOGRÁFICO AGUSTÍN CODAZZI. Guia simplificada para la elaboración del Plan de Ordenamiento Territorial de Ordenamiento Territorial Municipal. Bogotá: Convenio IGAC - Proyecto Checua - CAR - GTZ - KFW, 1998.

INVU. Manual de Planes Reguladores Instrumento de ordenamiento territorial. San José, Dirección de Urbanismo INVU, 2018.

LEFEBVRE, H. De lo rural a lo urbano. Barcelona: Península, 1978.

MASSIRIS, A. Fundamentos conceptuales y metodológicos de Ordenamiento Territorial. Colombia: Colección Investigación UPTC, 2005.

MIDEPLAN. "MIDEPLAN aprueba financiamiento a cantones que carecen de planes reguladores.” Disponible en: http://www.mideplan.go.cr/prensa/142-noticias-anteriores/1198-mideplan-aprueba-financiamiento-a-cantones-que-carecen-de-planes-reguladores. Acceso en: 27 oct. 2016.

MIVAH. Politica Nacional de Ordenamiento Territorial 2012-2040. San José, 2012.

PODER EJECUTIVO DE LA REPÚBLICA DE COSTA RICA, MINAE. “Manual de Instrumentos Técnicos para el proceso de Evaluación de Impacto Ambiental (Manual de EIA)". Diario Oficial La Gaceta. San José, mayo 2006. Disponible en: http:// www.pgrweb.go.cr/scij/Busqueda/Normativa/Normas/nrm_texto_completo.aspx ?param $1=$ NRTC $\&$ nValor $1=1 \&$ nValor $2=57061 \&$ nValor $3=62612 \&$ param $2=1 \&$ st rTipM=TC\&lResultado=2\&strSim=simp. Acceso el: 12 oct. 2016. 
. "Reglamento de la Transición para la Revisión y Aprobación de Planes Reguladores”. Diario Oficial La Gaceta. San José, sept. 2015. Disponible en: http:// www.pgrweb.go.cr/scij/Busqueda/Normativa/Normas/nrm_norma.aspx?param1 $=\mathrm{NRM} \&$ nValor $1=1 \&$ nValor $2=80064 \&$ nValor $3=101498 \& \operatorname{strTipM}=\mathrm{FN}$. Acceso el: 18 sep. 2016.

. "Reglamento General sobre los procedimientos de Evaluación de Impacto Ambiental (EIA)". Diario Oficial La Gaceta. San José, sep. 2004. Disponible en: http:// www.pgrweb.go.cr/scij/Busqueda/Normativa/Normas/nrm_texto_completo.aspx ?param $1=$ NRTC \&nValor $1=1 \&$ nValor $2=57061 \&$ nValor $3=62612 \&$ param $2=1 \&$ st rTipM=TC\&lResultado=2\&strSim=simp. Acceso el: 12 oct. 2016.

PRESIDENCIA DE LA REPÚBLICA DE COSTA RICA. "Decreto n. ${ }^{\circ}$ 38.782-MINAE-MAG-MIVAH-MIDEPLAN. Diario Oficial La Gaceta. San José, oct. 2006. Disponible en: https://documentos.mideplan.go.cr. Acceso en: 25 oct. 2016.

PRUGAM - Plan Regional Urbano de la Gran Área Metropolitana de Costa Rica 2008-2030. San José, 2008.

QUIRÓS, P. “Informe final de Gestión”, 21 de diciembre. [OFICIO Nº DIGH-399-16 de 2016]. Dirección de Investigación y Gestión Hidrica, SENARA. Disponible en: http://www.senara.or.cr/Comunicados/DIGH-399-16\%20INforme\%20final\%20 de\%20gestion\%20de\%20Carlos\%20ROmero.pdf. Acceso en: 08 ene. 2017.

RENDUELOS, C. y DEL OLMO, C. "Las Grietas de la ciudad capitalista. Entrevista con David Harvey". Revista Geográfica de América Central, n. 43, pp. 109-17, Heredia, 2009.

SALA CONSTITUCIONAL DE LA CORTE SUPREMA DE JUSTICIA. "Sentencia n. ${ }^{\circ} 11.862$ de Sala Constitucional de la Corte Suprema de Justicia”, de 29 de Julio de 2008. Disponible en: http://vlex.co.cr/vid/-499285250. Acceso en: 18 ene. 2017.

SANTOS, M. Por una geografía nueva. Madrid: Espasa-Calpe, 1990.

. Metamorfosis del espacio habitado. Barcelona: Oikus -Tau, 1996.

. Por otra globalización del pensamiento único a la conciencia universal. Bogotá: Convenio Andrés Bello, 2004. 
SAQUET, M. A. Por una geografía de las territorialidades y las temporalidades. Una concepción multidimensional orientada a la cooperación y el desarrollo territorial. La Plata: Universidad Nacional de La Plata/Facultad de Humanidades y Ciencias de la Educación, 2015.

\section{SERVICIO NACIONAL DE AGUAS SUBTERRÁNEAS RIEGOY AVENAMIEN-} TO. “Metodología general para la elaboración de los estudios hidrogeológicos para los planes reguladores”. Diario Oficial La Gaceta. San José, jul. 2015. Disponible en: http://www.pgrweb.go.cr/scij/Busqueda/Normativa/Normas/nrm_texto_completo.aspx param $1=$ NRTC $\&$ nValor $1=1 \&$ nValor $2=79774 \&$ nValor $3=103009 \& p$ aram2=1\&strTipM=TC\&lResultado=2\&strSim=simp. Acceso en: 18 sep. 2016.

SILVEIRA, M. L. O Brasil: território e sociedade no início do século XXI. Río de Janeiro: Record, 2004.

SOJA, E. En busca de la justicia espacial. Valencia: Tirant Humanidades, 2014.

"Venció plazo para planes reguladores para que Munis tengan comisión interinstitucional". Diario Extra. San José, abr. 2015. Disponible en: http://www.diarioextra. com/Noticia/detalle/256847/vencio-plazo-para-planes-reguladores. Acceso en: 11 ene. 2017.

ZOIDO, Florencio. “Geografía y ordenación del territorio". En Íber, Didáctica de las Ciencias Sociales. Geografía e Historia. Barcelona, n. 16, pp. 19-31, 1998. 


\section{Modelos de zonificación urbana y su implementación en Costa Rica}

Omar E. Barrantes Sotela

\section{Introducción}

Un proceso de ordenamiento territorial implica un significativo compromiso de participación de actores sociales, económicos, culturales y políticos, que definen una estrategia de organización del uso y ocupación del territorio. Estrategias que deberían construirse en criterios sustentados en estudios de carácter diagnóstico y pronóstico, que además consideren de manera exhaustiva las dimensiones de cada uno de los componentes del modelo territorial vigente y propuesto.

Al integrar las políticas y estrategias de desarrollo con el modelo territorial, no solo se promueve un ordenamiento territorial que favorece la gobernabilidad, sino que se convierte en un instrumento que orienta la planificación a nivel nacional, regional y local. Esto se concreta mediante planes que expresan o idealizan un proyecto territorial a largo plazo. Proyecto que debe ser deseable por la sociedad e implementado en un contexto real a través de pautas bien definidas (Alfaro-Rodríguez y Alfaro-Rodríguez, 2004; Massiris-Cabezas, 1993).

Una de las mayores preocupaciones en la elaboración de las propuestas de ordenamiento territorial, obedece a la creación de instrumentos capaces de establecer un régimen de uso, aprovechamiento y apropiación de los recursos del territorio. Esto puede ocurrir en diferentes dimensiones y escalas, ya sea en unidades de propiedad privada como los predios o más generales como las regiones, en las que se demarcan zonas de intervención y regulación. El propósito es discernir o indicar las capacidades optimas, adecuadas o incluso mínimas, para sostener un conjunto de actividades económicas o usos específicos. 
Como señala Mateo-Rodríguez (2014), el ordenamiento territorial es una estrategia para lograr un equilibrio territorial, y que debe estudiarse bajo la teoría sistémica. La Geografía ha adquirido un nuevo protagonismo debido al desarrollo teórico, metodológico y experiencia aplicada en los estudios territoriales, y por tanto su aporte y participación es esencial, para entender la complejidad de los procesos de organización espacial y las estructuras subyacentes que componen un territorio. El presente trabajo de investigación está orientado en el papel que desempeña la Geografía en una de las aristas fundamentales de un proceso de Ordenamiento Territorial y Planificación del Territorio, como es la elaboración de la propuesta técnica de Zonificación (Zoning) y sus reglamentos complementarios.

\section{Sobre las funciones de la zonificación urbana}

La teoría de zonificación y el uso eficiente de la tierra ha sido implementada alrededor del mundo. En Estados Unidos, los primeros casos modernos de ordenanzas fueron importados del modelo de zonas Alemán y se dieron en las ciudades de Los Ángeles (1908), Nueva York (1916) y Chicago (1923) (Kolnick, 2008; Warren, 2009). La zonificación tradicional norteamericana tiene como base sustancial, un tipo de codificación de zonas adoptado en el poblado de Euclid, Ohio, EEUU en 1926. Esa tipología (zonificación euclidiana) se caracteriza en la división o segregación de usos en zonas geográficas específicas con un estándar de dimensiones, que estipula las limitaciones o condiciones de desarrollo de actividades en cada una de las categorías previstas. Es además uno de los diseños de regulación de zona más recurrente y aplicado en el mundo, por su fácil implementación.

En Inglaterra a mediados del siglo $\mathrm{XX}$, las autoridades locales desarrollaban un plan local de política futura o planes de desarrollo unitario, para definir qué tipos de desarrollo estaban permitidos, y delimitar las áreas especiales en mapas de planes locales (policies map). Sin embargo, no tenían la formalidad del sistema de codificación norteamericano, y era una regulación más flexible. A su vez en Francia, el marco legal actual de regulación de zona proviene de la ley de 1967 , en la que se permite a las ciudades promulgar sus propios planes de zonificación (zoning plans). Estos seguían en un inicio un patrón similar al modelo euclidiano, pero que fue evolucionando a finales de los años 80, al incorporar obligaciones en la protección del suelo agrícola y 
la preservación de los espacios naturales; con una alta orientación a evitar el crecimiento urbano en superficie (anti-sprawlplans) y se les conoce como Plan Local d'Urbanisme (Romain, 2013).

La espontaneidad y la complejidad en la que ocurren los procesos urbanos, periurbanos y rurales, generan una gran diversidad de fenómenos de ocupación del espacio. Cuando se espera que estos fenómenos ocurran se les considera normales como en el caso del crecimiento urbano, los cambios de uso y la fragmentación de espacios naturales. Pero también, pueden existir otros procesos de ocupación que por efectos inesperados de una acción particular ocasionan un trastorno en el sistema urbano; a estos se les denomina procesos anómalos.

Estas anomalías pueden ser detonadas por una elevada intensidad y frecuencia de ocurrencia de procesos considerados normales. Algunos ejemplos son los asentamientos irregulares o aquellos localizados en áreas con amenazas, degradación o segregación de áreas urbanas y conflictos en la movilidad urbana. Para solventar lo anterior, los planificadores territoriales buscan la creación de diversas estructuras de regulación o control, que puedan ajustarse a los objetivos y alcances de la política de intervención urbana. Estas estructuras deben estar en correspondencia al modelo de ordenamiento territorial implementado o por implementar; con el propósito de minimizar los efectos negativos de la distribución espacial de un fenómeno particular (Hamoudi e Risueño, 2012; Türk et al., 2011).

Uno de los principales instrumentos de regulación en el Ordenamiento Territorial es la zonificación urbana. Esta se puede definir como la separación o división de un área geográfica administrativa con una jurisdicción delimitada en zonas continuas, que regula las características constructivas de la infraestructura, para que sus especificaciones de diseño y localización garanticen la funcionalidad urbana de la ciudad. Se establece así, una coherencia entre el propósito, la función y disposición estructural, con respecto a otros elementos que conforman un territorio.

En la actualidad los diseños de zonificación, se orientan tanto por la regulación, el control y establecer patrones de densidades constructivas; sino también por la forma y la capacidad de enlazar usos múltiples o mixtos que pueden ser compatibles, creando lugares más confortables para habitar. Estas nuevas prácticas de planificación incluyen un diseño urbano con desarrollo compacto de usos mixtos, protección de áreas naturales y agropecuarias, así 
como la incorporación de la gestión del riesgo por afectaciones de amenazas (antrópicas y naturales), que incluyen la mitigación del impacto por cambio o variabilidad climática.

Los controles sobre los usos de la tierra son creados y vigilados por los gobiernos locales, como parte fundamental de sus obligaciones de mantener y velar por el bien público y las iniciativas privadas. Para ello se conforma un conjunto de reglas que beneficien a la mayoría de los habitantes. Es un balance entre los derechos individuales y los derechos colectivos de la sociedad. Es sobre todo una representación de las negociaciones entre los intereses de los propietarios privados, y el bien común público, que es defendido por las organizaciones y las comunidades, y que debe ser garantizado por el Estado (Kolnick, 2008).

Mediante una apropiada conceptualización, la zonificación es un instrumento de ordenamiento territorial que racionaliza el ritmo y dirección del crecimiento urbano. Además, evita en lo posible la expansión aislada de la ciudad y la insuficiencia de servicios básicos, asociada a patrones dispersos, que introducen disfuncionalidades al sistema urbano (Schmidt y Buehler, 2007; Warren, 2009).

Una de las principales críticas a la zonificación, se deriva precisamente del separar el territorio en zonas según su función predominante o por necesidad de control especial. Su diseño no necesariamente ocurre mediante criterios claros que faciliten las labores de gestión. Sin embargo, es necesario asegurar a cada propietario las condiciones de las regulaciones, restricciones y posibilidades del ius utendi $i^{1}$ de la propiedad. También, permite iniciar un proceso de intervención y de planificación urbana con noción prospectiva.

De acuerdo a la noción prospectiva, se deben proponer lineamientos y acciones, así como medidas de adaptación o mejora en un período temporal definido, con el propósito de evitar la saturación de la capacidad instalada en las ciudades. Por tanto, se debe evitar la arbitrariedad en la construcción de las categorías, mediante la fundamentación técnica-científica y concebida con la participación de la comunidad.

1 Es el derecho de uso sobre la cosa, en este caso sobre el bien inmueble. El propietario tiene el derecho de uso de la cosa para sus intereses y en función social del derecho, mientras que la conducta no viole la jurisprudencia o los preceptos legales establecidos, así como que causen lesiones a los derechos de otros propietarios. Por ejemplo, ocasionar un daño o peligro que pueda afectar a otros propietarios. 


\section{Alternativas de regulación urbana}

Con las nuevas teorías, prácticas y políticas; se ha replanteado los códigos urbanos regulatorios para darle mayor flexibilidad y solventar las ineficiencias económicas que ocurren con la zonificación tradicional. Entre las principales críticas que se le atribuye al modelo euclidiano, es que promueve la exclusión estricta de usos y la segregación social que ocurre de los efectos de plusvalía y renta urbana en la delimitación de las zonas. Es una forma expresa de maximizar el valor de la propiedad al excluir o prohibir aquellos usos o actividades molestas a un grupo particular de propietarios. Otra carencia, es que adolece de un apropiado análisis de los impactos ambientales y sociales que pueden ocurrir en un territorio, en la aplicación de una normativa que se conoce es rígida.

Por estas y otras razones, los profesionales vinculados en la planificación urbana conciben nuevas formas de zonificación y regulación. En su mayoría con un enfoque que busca mejorar la calidad de vida de los habitantes de un área urbana, a través de la inclusión y mixtura de usos, así como controlar el tamaño y el desarrollo urbano disperso de las áreas periurbanas. A continuación, se presentan cinco métodos de regulación urbana según su fundamentación básica: la Zonificación por rendimiento, la reglamentación de zonas con derechos de desarrollo transferible, zonificación por incentivo, el modelo de control y administración del crecimiento y por último la regulación por crecimiento inteligente.

\section{Zonificación por rendimiento}

También denominada zonificación por impacto o zonificación flexible (Kendig y Connor, 1980). La zonificación por rendimiento regula el diseño y la ubicación de un uso, basado en las características de un sitio en particular para apoyar el desarrollo. Se indica la intensidad del uso que es aceptado, mientras que el "estándar de rendimiento" se estipula en una ley o norma específica. Un ejemplo sería, el estándar máximo de ruido permitido de un local comercial. El ruido aceptado es establecido en el reglamento para el Control de Contaminación por Ruido. Por tanto, esta actividad podrá ser localizada en una zona residencial, mientras cumpla con las disposiciones vigentes. Los propietarios y desarrolladores tienen flexibilidad en la forma constructiva y del cómo podrán cumplir con la reglamentación estipulada. 
De acuerdo a estudios realizados por Exner(1996), Van Wijk; et al. (2011) y Warren (2009), se ha probado la utilidad de la zonificación de rendimiento para zonas de superposición reglamentaria alrededor de aeropuertos e industrias. Con el tiempo, también se ha desarrollado más en casos de áreas con amenazas, o con ciertas características de transición de usos. A pesar de esto, según Warren (2009), muchos de los lugares que adoptaron este tipo de zona en Estados Unidos, regresaron a la zonificación euclidiana tradicional. Debido a la carencia de lineamientos específicos y a las dificultades en explicar y aplicar complejos estándares de rendimiento. Autores como Harper; et al. (2008) señalan no adoptar este tipo de modelo, al no encontrar casos exitosos y recalcan los efectos impredecibles, que puede ejercer en el sistema urbano. Una investigación de John A. Humphreys Associates (2002), recomienda que su uso sea complementario al modelo de zonificación euclidiano tradicional.

\section{Zonas con derechos de desarrollo transferible}

Este tipo de reglamentación no es tan utilizada y cuenta solo con pocos ejemplos de aplicación. Permite que las parcelas puedan cambiar de zona según su capacidad potencial de uso. En algunos casos, sucede que un nuevo desarrollo en los límites entre zonas puede afectar a un propietario, por lo que se le permite cambiar de categoría de zona, con el propósito de que pueda recuperar sus potenciales perdidas debido a la nueva condición de vecindad con otro tipo de regulación, y por consiguiente pueda equiparar las condiciones de beneficios que reciben otros propietarios con la suya. Entre las deficiencias de este tipo de norma, están la concatenación de múltiples cambios y crecimiento desmedido de zonas; así como la definición del área de cambio bajo esas características. Por consiguiente, solo se suele aplicar a bloques de cuadras o concorde a distancias de Manhattan. No obstante, es un tipo de regulación que puede emplearse en la modificación o actualización de un plan de ordenamiento, en el que por medio de sustento técnico puede aplicar una nueva recalificación a un bloque o unidad mínima de planificación urbana.

\section{Zonificación por incentivo}

Concebida como una situación en la que tanto el desarrollador como el planificador, obtienen lo que buscan en su concepción del modelo territorial. Formalmente se le puede definir como, el proceso mediante el cual la autoridad 
local puede conceder ciertas capacidades constructivas o de desarrollo adicional, pero a cambio de que el propietario o desarrollador genere o garantice un equipamiento, beneficio o una utilidad pública; que deben ser especificadas en las ordenanzas de regulación. Por ejemplo, a cambio de permitir un piso adicional en un edificio, el proyecto urbanístico puede incluir una plaza pública, zonas verdes, o cualquier otro tipo de amenidades. En una consideración técnica, se prevé que, mediante el aumento del área de construcción, se obtiene más ingreso a cambio de un incremento marginal en los costos de mantenimiento de la nueva amenidad, que a su vez beneficia al público en general. Estos incentivos, en muchas ocasiones son rechazadas por los desarrolladores, debido a que los costos asociados no justifican el incremento de densidad constructiva. En algunos casos no existe cesión de estas amenidades al municipio, por lo que incluso espacios que se consideraban públicos en realidad no lo son, o se convierten en espacios de segregación o de uso exclusivo, y por su diseño poco funcional no responden a las necesidades de la población.

\section{Modelo de control y administración del crecimiento}

Regula estrictamente los nuevos desarrollos, tanto hacia el espacio abierto y la intensificación de usos y densidades existentes. Se utiliza el razonamiento lógico de la zonificación piramidal, para influir en como ocurre el crecimiento. Para eso, se crea regulación específica orientada a disminuir o detener el ritmo de cambio de uso, mediante el control de densidades, disponibilidad de tierra, implementación de usos mixtos, el ritmo de crecimiento y la definición de un límite de crecimiento urbano (Downs, 2003).

Se ha reportado por Porter (1986), que entre los gobiernos locales que han utilizado está forma de organización, se establece en un período temporal específico, una cantidad predefinida de nuevos proyectos de desarrollo urbano que serán aprobados por categoría de zona. Además, su uso se ha adaptado como complemento a los reglamentos y para estabilizar el tamaño de las áreas urbanas. No obstante, Porter (1997) y Warren (2009) reportan una serie de efectos secundarios, como mercados negros para los permisos de construcción y el efecto de crecimiento urbano en pídola. En especial para aquellas áreas que están fuera de las restricciones de crecimiento, lo que provoca la desaparición más rápida de áreas naturales y agropecuarias.

Cunningham (2005) indica que los controles de crecimiento, sí bajan las probabilidades de desarrollo fuera del límite entre un $28 \%$ a un $35 \%$, pero 
una vez que las limitaciones y controles son impuestos, la volatilidad de los precios no detiene los desarrollos urbanísticos. Debido a que los controles de crecimiento reducen el valor asociado al tiempo de espera de desarrollar, por medio de la limitación de la incertidumbre sobre el mejor uso de la tierra de los terrenos vacantes. Esto genera que los valores de los terrenos dentro del límite de contención urbano, relativamente empiecen a crecer en un período a corto plazo con respecto a los que están afuera del límite. Lo anterior se explica, por la especulación de terrenos conforme disminuyen las áreas disponibles para urbanizar y a la existencia de otro tipo de amenidades o servicios (BarrantesSotela et al., 2015). Es posible pronosticar, que sí un conjunto de centros urbanos practica de manera individual y local la administración de crecimiento, eventualmente causará que el alojamiento se vuelva económicamente inalcanzable para los habitantes. Al contrario, sí se equilibra el control de crecimiento a una escala regional, puede permitir a los centros urbanos la práctica de la administración del crecimiento sin tener los efectos negativos en la economía local.

\section{Crecimiento inteligente (Smart Growth)}

Es una de las últimas tendencias y se basa en el concepto de las ciudades "inteligentes". Todavía no existe un consenso sobre su definición formal, en términos de establecer que es inteligente y que no lo es (Nelson, 2002). Sin embargo, presenta ciertos principios, esquemas y lineamientos, que tienen como fundamento la idea de que la zonificación convencional es un factor importante en el crecimiento urbano (sprawl). Además, considera que la regulación debe replantearse para propiciar los procesos de renovación urbana al interior de la ciudad, así como fomentar un desarrollo ambientalmente equilibrado y desincentivar la ocupación urbana de los espacios verdes o terrenos destinados a la actividad agropecuaria (greenfields).

En principio este modelo busca desarrollar temas como conectividad, circulación, inmobiliario urbano y el uso de los predios de una manera mixta, tanto en densidad como en tipología. Además, tiene una acogida positiva por planificadores y desarrolladores, ya que una forma de alcanzar los objetivos propuestos es mediante la revisión, auditoria y renovación de los códigos normativos locales, en aquellos casos en los que ya se dispongan, o de la elaboración de un código reglamentario modelo construido a partir de experiencias positivas. Entre las principales observaciones a este modelo de 
zonificación, es que para su implementación es fundamental disponer de un marco regional que logre integrar las propuestas locales de planificación de una manera más funcional.

\section{Sobre las modificaciones y actualizaciones de zonificación}

Sin importar el enfoque o alternativas de zonificación, lo ideal antes de iniciar cualquier proceso de ordenamiento y planificación territorial es establecer los principios y los objetivos en los que se orientará la construcción del modelo territorial. Las diversas propuestas de regulación urbana se basan del análisis previo, es decir el diagnóstico del modelo territorial. Según Benabent (2016) las propuestas territoriales se pueden agrupar en: a) cómo se modela y entienden los factores causantes de la evolución de la forma urbana, b) la evaluación de la efectividad de las políticas de intervención y c) aquellas propuestas de diseño experimental, que se construyen a partir de fuertes evidencias visibles en el territorio.

No obstante, en la práctica es posible evidenciar que las propuestas de planificación provienen de un ejercicio metodológico cuasi-experimental. Además, carecen de un análisis exhaustivo que permita integrar los resultados más significativos del diagnóstico a la propuesta. Esto supone, la necesidad de realizar modificaciones o actualizaciones a los mapas y reglamentos.

Para Dispensa (2004) las modificaciones o ajustes de una zonificación pueden evaluarse en tres formas específicas: 1) su contribución al desarrollo en superficie, 2) los efectos ambientales que se originan a partir de la aprobación de proyectos urbanos, y 3 ) el impacto en la composición socio-económico de una zona. Teniendo en cuenta lo anterior, en la literatura constantemente se repiten algunos lineamientos fundamentales que las zonificaciones y sus reglamentos deben considerar.

1. Limite de crecimiento urbano: Se propone un límite a la expansión del crecimiento urbano con características de distribución espacial en pídola. En algunos casos, en la zona periférica del límite se aumentan los requisitos necesarios para la formalización de los desarrollos urbanos, con el fin de estos sean económicamente inviables.

2. Ocupación de áreas disponibles en los centros urbanos: Debe visualizarse como un complemento del limite de crecimiento urbano. 
En principio se desincentiva el crecimiento en la zona periférica, pero también debe propiciarse la normativa que fomente la ocupación de áreas vacantes o subutilizadas en el interior de los centros urbanos, al favorecer la densificación, la compacidad y la renovación urbana.

3. Preservación de las áreas de protección especial: Con el límite de crecimiento urbano se busca preservar los espacios abiertos. En adición, las políticas contra el crecimiento espontáneo pueden orientarse a reconocer la importancia de estos espacios, como las zonas especiales de protección agropecuaria y las áreas de conservación ambiental. Estas áreas deben ser preservadas de la invasión urbana, para el correcto funcionamiento de la ciudad.

4. Zonificación tipo clúster: Se prioriza en preservar los espacios abiertos y crear desarrollos compactos al requerir áreas urbanas separadas y rodeadas significativamente por retiros y espacios abiertos contiguos.

5. Imposición taxativa: Es una medida que trata de incentivar los anteriores lineamientos, al agregar una carga taxativa diferenciada a los desarrollos en las zonas ambientalmente esenciales o críticas, así como los proyectos urbanísticos próximos al limite de crecimiento urbano.

6. Criterios de modificación y ajustes de los reglamentos: El proceso para realizar una modificación a los reglamentos debe ser claro. Se deben crear indicadores para evaluar los efectos de la zonificación en el sistema urbano (monitoreo). Esto permite elaborar criterios para posibles estrategias de modificación o ajuste. Es importante establecer un período temporal para la revisión de los indicadores.

A continuación, se discutirá las características de los modelos y enfoques de zonificación implementados o propuestos en Costa Rica.

\section{Los modelos de zonificación implementados en Costa Rica}

En Costa Rica uno de los primeros esfuerzos de elaboración de una propuesta de zonificación fue iniciado por Solow (1949) a mediados del siglo pasado. Este señalaba que la ciudad de San José estaba creciendo de una forma rápida y concentraba un porcentaje muy alto de la población, que empezaba a desbordarse por sus extremos hacia las áreas rurales (sprawl). Este fenómeno de 
crecimiento desbordado y sin control, contribuía al cambio de las áreas de uso agrícola (cultivos de café) al uso urbano. También se indica, que no existía un plan de desarrollo urbano, ni oficina encargada de la acción de planificación en el área metropolitana de San José y establecía unas recomendaciones de zonas y proyectos de infraestructura específicos. Además, la participación de otros destacados planificadores como Garcés, Kayanan y Kalnisns, dejaron la inquietud entre las autoridades del Estado para iniciar estudios urbanos en Costa Rica (Mora-Ramírez, 2003).

Con la promulgación en 1954 de la Ley No. 1788 que crea el Instituto Nacional de Vivienda y Urbanismo (INVU) y su suplemento la Ley Planificación Urbana No. 4240 del quince de noviembre del 1968, se establece la rectoría institucional en la temática de gestión y organización del territorio, dando inicio formalmente la planificación urbana en Costa Rica. También, define el concepto de zonificación como la división de una circunscripción territorial en zonas de uso, para efecto de su desarrollo racional. La cual debe ser instrumentalizado mediante el Plan Regulador Urbano.

El INVU, en sus dos oficinas técnicas especializadas: el Departamento de Urbanismo y la Oficina de Planificación del Área Metropolitana empezó la redacción de una ordenanza de zonificación y los primeros estudios relacionados a la regulación de uso de la tierra (Jenkins-Dobles, 1969). En términos generales el plan regulador estaba constituido por el mapa de zonificación y su reglamento. Es así como la primera zonificación ${ }^{2}$ con carácter oficial en Costa Rica es la del distrito primero del cantón de Cañas de la provincia de Guanacaste, vigente desde el 18 de julio de 1980 y publicada en el periódico oficial la Gaceta n. 137.

Sin embargo, el INVU a finales de 1973, al considerar que la elaboración de propuestas separadas resultaba ser inoperantes y demasiado particularizados, ordenó un estudio total del Área Metropolitana que serviría como una línea base u orientadora para cada municipio (Mora-Ramírez, 2006). En el año de 1982 se aprobaría el Plan Regional Metropolitano Gran Área Metropolitana, mejor conocido como Plan GAM-82. No obstante a nivel cantonal se aprobarían los Planes Reguladores parciales en los distritos primeros de Puntarenas (1981), Coto Brus (1981), San Carlos (1982), Corredores (1982), Pococí (1982), Liberia (1983), Santa Cruz (1983) y Buenos Aires (1984). Esto conformaría

2 Existe un primer borrador de reglamento de zonificación de 1975 para el distrito central del cantón de Heredia, que no fue publicado por el INVU. 
un sistema central de planificación en la GAM, y establecería un desarrollo controlado de ciudades periféricas en el resto del país.

El diseño de zonas de estos planes era muy básico y consistía en establecer zonas generales a partir de la división de cuadras, a las que se le asignaba sencillas reglas de uso, altura, densidades e intensidad. Las principales limitantes o restricciones asociadas a los desarrollos urbanos eran los establecidos en el Reglamento para el Control Nacional de Fraccionamientos y Urbanizaciones, entre los que destacan las pendientes mayores del 20\%, zonas de inundación, deslizables o similares, cañones de río o de protección; las mismas están definidas en el Reglamento 3.391 de Control Nacional de Fraccionamientos y Urbanizaciones. ${ }^{3}$ Las categorías más utilizadas por el INVU fueron las zonas de vivienda, áreas verdes, comercio, público institucional e industria. Este tipo de diseño usa como base una zonificación euclidiana con una estructura piramidal modificada. ${ }^{4}$ Es importante recalcar que, en Costa Rica, la mayoría de Planes Reguladores aprobados y vigentes usan este tipo de zonificación, y que ArrietaChavarría (2010) afirma, la base teoría es deficiente y se realiza en la práctica, a veces de forma chapucera.

Con la promulgación en Costa Rica de la legislación ambiental en la década de los años noventa, se incorporan nuevas herramientas y requisitos para la aprobación de los instrumentos de planificación regional, local y consecuentemente de la zonificación urbana. Un ejemplo es el artículo 29 de la Ley Orgánica del Ambiente, que establece se debe:

... para el ordenamiento territorial en materia de desarrollo sostenible, se considerarán los siguientes fines:

3 Reglamento 3.391 del INVU, Gaceta n.o 57 del 13/12/1982 y sus reformas en: Gaceta n.o 96 del 21/5/84, Gaceta n.o72 del 17/04/86, Gaceta n.o 10 del 15/01/87, Gaceta n.o 137 del 2/07/87, Gaceta n.o 96 del 19/05/89, Gaceta n.o 180 23/09/91, Voto 4.205-96 del 20 de agosto de 1996, Gaceta n.o 130 del 6/07/99, Gaceta n.o 107 del 5/06/03, Gaceta n.o 74 del 19/04/05, Gaceta n.o 199 del 17/10/05, Gaceta n.o 78 del 23/04/09.

4 Una zonificación de estructura piramidal, corresponde a un tipo de diseño que es recursivamente excluyente con las categorías; es decir un uso industrial, solo puede ser localizado en una zona industrial, pero el comercio puede ser establecido en zonas comerciales e industriales, y así subsecuente mente con respecto a las otras categorías definidas, siendo la vivienda la categoría en la cúspide de la misma. 
a. Ubicar, en forma óptima, dentro del territorio nacional las actividades productivas, los asentamientos humanos, las zonas de uso público y recreativo, las redes de comunicación y transporte, las áreas silvestres y otras obras vitales de infraestructura, como unidades energéticas y distritos de riego y avenamiento.

b. Servir de guía para el uso sostenible de los elementos del ambiente.

c. Equilibrar el desarrollo sostenible de las diferentes zonas del país.

d. Promover la participación activa de los habitantes y la sociedad organizada, en la elaboración y la aplicación de los planes de ordenamiento territorial y en los planes reguladores de las ciudades, para lograr el uso sostenible de los recursos naturales.

Si bien, se formaliza en el mandato de considerar la dimensión ambiental en el proceso de planificación nacional, regional y local; en este período no se tenía claro que parámetros o variables se debían considerar en dicho proceso, así como los requerimientos mínimos o alcances que debían contener las normativas locales de regulación. Según Obando (2011), es en este punto que Costa Rica, da los primeros pasos en el denominado ordenamiento territorial bajo el enfoque del desarrollo económico y el de sustentabilidad. Aunque tal y como indica Ramírez y Villalobos (2014), es un proceso que ocurre de manera desarticulada y con iniciativas dispersas.

Uno de los esfuerzos para incorporar de manera oficial las variables ambientales en la elaboración técnica de zonificación ${ }^{5}$ y en un plan regulador es el Manual de Procedimientos para la Redacción y Elaboración de Planes Reguladores, elaborado por la Unidad de Planificación Territorial de la Dirección de Urbanismo del INVU en el año 2001, primero como una directriz, que fue oficializado como reglamento hasta su publicación en la Gaceta n. ${ }^{\circ} 58$ del 22/03/2007. La finalidad de este documento fue generar los lineamientos descritos en las leyes n. ${ }^{\circ} 4.240$ de Planificación Urbana y n. ${ }^{\circ} 7.554$ Orgánica del Ambiente en su Capítulo VI, para la elaboración y propuesta de planes reguladores. Adicionalmente, la Sentencia de fondo de la Sala Constitucional 2002-001220, ordena que todo plan regulador de desarrollo urbano debe contar, de previo a ser aprobado y ejecutado, con un examen del impacto ambiental. Pero es hasta en la Gaceta n. ${ }^{\circ} 85$ del 04/05/2006, mediante

5 La elaboración técnica de zonificación se contempla en la fase de propuestas del Plan Regulador. 
el Decreto Ejecutivo n. ${ }^{\circ}$ 32.967-MINAE que se hace operativo el mandato de la Sala Constitucional, ${ }^{6}$ al establecer el procedimiento de la valoración de los impactos ambientales en los instrumentos de evaluación de impacto ambiental. ${ }^{7}$

Para efectos prácticos el Manual de Procedimientos para la Redacción y Elaboración de Planes Reguladores del INVU, en la fase de propuestas o propositiva, se indican las características y contenidos generales que debe contener el reglamento de zonificación y su mapa, aunque no indica su construcción metodológica. En su definición mantiene el esquema de una zonificación tradicional, pero que se complementa con la jurisprudencia constitucional y los reglamentos en materia ambiental de instituciones como SENARA ${ }^{8}$ y SETENA.

Divide el área a planificar en zonas de uso para establecer una clasificación de los inmuebles de acuerdo con el área, dimensiones, localización, retiros, cobertura, entre otros. Con la finalidad de establecer su uso racional. INVU (5.4.1. Reglamento de Zonificación).

Una nueva tendencia considera que las regulaciones urbanas deben incluir como objetivo la protección del medio ambiente, y se desarrollan criterios para la evaluación ambiental de planes urbanos regionales y planes reguladores locales. Se inicia la valoración de la fase de ejecución del proceso urbanizador o de la construcción sostenible ${ }^{9}$ con especial atención en la regulación del uso de materiales

6 Sentencia de fondo de la Sala Constitucional 2005-009765 del Expediente 05-0035890007-CO, ordena a SETENA publique el "Manual de Instrumentos Técnicos para el Proceso de Evaluación de Impacto Ambiental" y a la Municipalidad de Escazú a someter el Plan Regulador al proceso de viabilidad ambiental ante esa entidad.

7 Se introduce la variable ambiental en los Planes Reguladores u otra Planificación del uso del suelo, con el Manual de Instrumentos Técnicos para el proceso de Evaluación de Impacto Ambiental, instrumento que se indica a su vez en el Manual de Procedimientos para la Redacción y Elaboración de Planes Reguladores.

8 Sentencia de fondo la Sala Constitucional 2004-001923, ordena la protección de las áreas de recarga-descarga de los mantos acuíferos existentes en el Cantón Poás.

9 Mediante Decreto Ejecutivo n. ${ }^{\circ}$ 31.849: Reglamento General sobre los Procedimientos de Evaluación de Impacto Ambiental, que establece la base para elaborar el protocolo, como parte del Manual de Procedimientos Técnicos. 
no contaminantes, eficiencia energética de edificios, la gestión de residuos de la construcción, demolición, y los costos del ciclo de vida útil del entorno construido. Según Dorantes y Nettel (2011), estos aspectos de la regulación ambiental que influyen en el urbanismo se ha denominado como urbanismo sectorial, y es el enfoque que actualmente trata de ser implementado en las zonificaciones del país.

\section{La forma de zonificar en los Planes Regionales, después del Plan GAM-82 El PRUGAM (2008-2030)}

Según la Entidad Gestora del Proyecto PRUGAM (2008), con la fase III-A del Plan Nacional de Desarrollo Urbano se pretendía la actualización del Plan GAM de 1982. Tenía como fin mejorar o impulsar los centros urbanos del Gran Área Metropolitana, mediante un marco legal integral en temas de ordenamiento territorial y sostenibilidad ambiental, que favoreciera la integración social, la competitividad económica y la estructura de las ciudades.

Si bien en la etapa de diagnóstico, se realizaron estudios individuales y específicos bastante detallados, no se logró plasmar muchos de esos resultados en la propuesta de macro-zonas y de la zonificación urbana general del plan regional. En algunos casos la definición de zonas era contradictoria en términos de los parámetros urbanísticos establecidos o incluso se traslapaban funciones y aplicabilidad jurisdiccional entre gobiernos locales y el gobierno central. Es muy interesante la afirmación de Carazo (2011), que sugiere que con la propuesta del Plan Regional Urbano del Gran Área Metropolitana (PRUGAM), se diseña una estrategia de macro-zonificación por rendimiento, y lo cataloga como una zonificación ambiental territorial. También menciona que la propuesta del PRUGAM se construyó a una escala regional en base a la capacidad de uso y de carga ambiental. Aunque se puede afirmar que sólo demarco espacialmente los resultados del Índice de Fragilidad Ambiental (IFA), en el que se establecen las limitaciones naturales del suelo, de riesgo, y otras condiciones naturales propias de la GAM, tal y como se establece en el Decreto Ejecutivo n. ${ }^{\circ}$ 32.967-MINAE.

La zonificación propuesta fue objeto de múltiples observaciones por varios sectores institucionales y de la sociedad civil. Para sus efectos la propuesta planteaba delimitar solo tres grandes zonas o "macro zonas" que fueron denominadas como: a) Zona de Potencial de Protección y Conservación, b) Zona de Potencial de Producción Agropecuaria y c) Zona de "Potencial 
Urbano"; en las que no existía un detalle de los estándares de rendimiento a implementar, es decir no se fijaban los lineamientos para el uso y gestión de estas macro zonas. Es importante recordar que una limitación de este tipo de zonificación es la complejidad de establecer lineamientos específicos y los estándares de rendimiento.

Esta fue una de las razones de fondo por las cuales no se aprobó el PRUGAM por el INVU. Según Informe Final de Revisión de la Propuesta de Actualización del Plan Regional del Gran Área Metropolitana, que emitió la Unidad de Planificación territorial (2010) y que conoció la Junta Directiva del INVU en la Sesión Ordinaria n. ${ }^{\circ} 5.806$ de del 28 de abril de 2010, se estableció que el proyecto presentó como mapa de zonificación regional, el mapa de IFA asociado a un reglamento general, que no indicaba los criterios técnicos ni específicos en los que sustentaban las categorías de zonas propuestas.

[...] debe quedar suficientemente claro que los IFAS son apenas un componente de la Planificación Urbana, importante, pero representan solamente una variable más, el proceso de planificación urbana como ya se dijo en páginas anteriores, es mucho más complejo que la aplicación de una sola variable, es requisito fundamental desde la perspectiva científico técnico la integralidad del conjunto de las variables analizadas (Unidad de Planificación Territorial, 2010, p. 106).

Como una curiosidad, el artículo 2.2 del Decreto Ejecutivo n. ${ }^{\circ}$ 32.967-MINAE, indica claramente que:

El mapa de zonificación de IFA, NO debe ser considerado ni interpretado como el mapa de zonificación de uso del suelo que genera el Plan Regulador o el Plan de Uso del Suelo, por el contrario, es un insumo del componente de diagnóstico, que aplica la premisa ambiental y establece las bases para que las autoridades en conjunto con los otros actores sociales involucrados puedan decidir sobre los usos más acertados y apropiados que se darán al suelo del territorio objeto de la planificación.

Además Badilla y otros (2009) señalaron grandes deficiencias en la Zonificación de Plan Regional de la GAM como: 
De la zonificación de la GAM\}. En el apartado Conceptos y Objetivos (pág. 61 Tomo II, Propuesta, se indica que: De acuerdo a los estudios técnicos realizados, los indicadores de fragilidad ambiental y el análisis de todas las variables que inciden sobre el territorio de la GAM, esta se divide en tres grandes zonas a saber: La zona de potencial de protección-conservación, La zona de potencial de Producción agropecuaria, La zona de potencial urbano". Se indica, en el siguiente párrafo que: "La definición de límites geográficos o territoriales de la GAM... fundamentados en los estudios de fragilidad ambiental, capacidad de carga, y posibilidades de crecimiento de alta densidad (Badilla et al., 2009, p. 9).

[...] cabe indicar que:

No hay datos, variables ni indicadores en el documento diagnóstico que brinden los elementos necesarios para dar criterio o aportar observaciones acerca de la zonificación propuesta a nivel regional (Badilla et al., 2009, p. 9).

La Contraloría General de la República (2012), indicó que los datos de los mapas tenían incongruencias en las fuentes y la legibilidad de la simbología de los mapas oficiales no era apropiada. Esto sin duda no es aceptable cuando se maneja un mapa de zonificación, que, por sus características vinculantes y legales, debe ser un instrumento claro y preciso, aun cuando se trate de un estudio de escala regional.

En los casos de los Planes Reguladores para los 31 cantones, MoraRamírez y Acuña-Araya (2009) advierten que en los 19 cantones homologados por el PRUGAM, los mapas y reglamentos de zonificación de usos del suelo eran muy generales y que era necesario ajustar cada reglamento al contexto y realidad de cada lugar. Mientras que con el establecimiento de sectores se trataba de un mecanismo que pretendía darle cierta particularidad a cada una de las zonas definidas, sería muy difícil de implementar, dado que cada sector carecía de elementos de referencia y codificación gráfica para ubicarlos. Otro aspecto importante que se menciona por Mora-Ramírez y Acuña-Araya (2009), era que los reglamentos propuestos se limitaban a regular solo lo necesario, sin integrar los diferentes parámetros estudiados en el diagnóstico y pronóstico. Es decir, constituían documentos aislados del resto de las propuestas del Plan Regulador. 
Por lo que se considera que no tenían una visión de desarrollo sostenible. Además, perdían la visión de planificación más propositiva y estratégica.

Si bien estos reglamentos de zonificación debían respectar la macrozonificación por rendimiento a un nivel local, tal y como lo conceptualiza (Carazo, 2011). Esa recomendación solo quedo en la intención, pues la construcción de las zonificaciones de los Planes Reguladores quedó al fin de cuentas como un listado muy breve de usos permitidos y restricciones urbanísticas. Asociado a una ficha de parámetros urbanísticos, con una tipología de zonificación tradicional.

\section{POT/GAM 2011-2030}

Con la fallida aprobación del PRUGAM, el INVU retoma la labor de actualizar el Plan GAM82 mediante el Plan de Ordenamiento Territorial de la Gran Área Metropolitana (POT/GAM 2011-2030). Esta iniciativa primero se propone como meta, la adecuación y la entrada en vigencia de todos y cada uno de los Planes Reguladores de las Municipalidades que componen la Gran Área Metropolitana, y como principal objetivo; mejorar las condiciones de vida de la población, la protección del ambiente, los recursos naturales esenciales para asegurar la salud y la vida de las personas y el desarrollo, en función de los principios de sostenibilidad para la Región Central del país, a través de una mayor competitividad de dicho espacio económico, derivada de una mayor eficiencia y calidad de su oferta de servicios y espacios.

En base a los estudios técnicos de la etapa de diagnóstico del PRUGAM, este plan proponía una zonificación regional metropolitana con 4 zonas y la siguiente tipología de zonas y subzonas:

1. Zona de Protección: La Cordillera Volcánica Central, es el área que comprende el sector norte de la GAM en su parte montañosa y boscosa; y del lado sur, comprende los cerros de Escazú, hasta colindar con las estribaciones de la Cordillera de Talamanca. Tiene características y funciones de conservación principalmente, permitiéndose usos de conservación, investigación, turismo y residencial de acuerdo al marco jurídico vigente. Es el área comprendida por todas las zonas donde el Índice de Fragilidad Ambiental Integrado o cualquier otra 
variable ambiental aprobada, tiene la valoración de ser muy de alta fragilidad ambiental. Con las siguientes subzonas:

a) Subzona de Protección Absoluta de nacientes, su área de flujo y por riesgos.

b) Subzona de Parques Nacionales.

c) Subzona de Protección Absoluta de ríos y quebradas.

d) Subzona de Áreas Silvestres Protegidas 1. Divisorias de Aguas.

e) Subzona de Áreas Silvestres Protegidas 2. Protección de Laderas.

f) Subzona de Cautela Especial de Ujarraz.

2. Zona Agropecuaria: Esta zona comprende las áreas donde los Índices de Fragilidad Ambiental u otra variable ambiental aprobada, tienen una condición de alta fragilidad ambiental, según las descripciones del protocolo ambiental establecido por la SETENA para la incorporación de la variable ambiental en los planes de ordenamiento territorial.

a) Subzona Agropecuaria de Cartago

b) Subzona Agropecuaria del Norte de la GAM

3. Zona Urbana: Esta zona es la que, desde el punto de vista de los Índices de Fragilidad Ambiental u otra variable ambiental aprobada, presenta una condición de moderada fragilidad y permite una mayor potencialidad de ser aprovechada para fines del desarrollo urbano. Se subdivide en:

a) Subzona Industrial (Con 5 zonas diferentes)

b) Subzona Institucional Comunal

c) Subzona De Usos Mixtos

d) Subzona De Núcleos Residenciales Predominantes

e) Subzona De Corredores Financieros, De Alta Tecnología y Comerciales (Con 4 áreas de funcionamiento)

f) Subzona Verde. La Red Verde

I. Parques Urbanos Metropolitanos

II. Parques Recreativos Urbanos 
III. Protección y Corredores Verdes y Biológicos IV. Protección de ríos y quebradas

a) Subzona De Corredores Turísticos (Con 5 Corredores)

b) Subzona Institucional En Los Centros Cívicos Históricos

c) Subzona Mixta Comercial En Los Centros Cívicos Históricos

d) Subzona Residencial Predominante De Baja Densidad

e) Subzona Urbana Existente y de Potencial Urbano a Reglamentar por los Planes Reguladores

I. Municipales.

II. Subzona De Vialidad y Transporte

III. Subzona De Redes e Infraestructura.

4. Zona de Cautela Urbana. Esta zona presenta según los Índices de Fragilidad Ambiental, condiciones de moderada fragilidad, permitiendo el desarrollo urbano.

Está tipología, indica además disposiciones específicas ${ }^{10}$ a otras áreas y establece Zonas de Recarga Acuífera y Zonas de Protección Paisajística, está última a criterio de los gobiernos locales. Al contrario de las definidas macrozonas propuestas en el PRUGAM, el POT/GAM planteaba un reto en la implementación y gestión de las zonas. Al considerarse como una zonificación granulada. Esto ocurre al observar la escala de implementación con respecto al uso desproporcionado de una gran cantidad de zonas, subzonas y casos localizados de reglamentación. Corresponde más a una tipología de reglamentación de uso compacto y que en otros países está más orientada propuestas de escala grande, como por ejemplo para reglamentar el inmobiliario urbano de una ciudad.

Se debe indicar que existen diversas métricas espaciales para determinar cuándo una zonificación cae bajo esta anomalía, algunas son: distancia más cercana al uso o zona diferente, el tamaño de uso singular de zonas, desarrollo en pidola y la distancia rectangular o de Manhattan; así como se pueden emplear los índices para variables nominales de concordancia asimétricas de Jaccard o

10 Por ejemplo: las disposiciones de parcela mínima productiva en las zonas agropecuarias. 
de Dice y Sorensen. Mientras que, a nivel cuantitativo, se puede analizar los traslapes de las competencias de regulación de la propuesta regional y local.

Entre muchos grupos académicos y expertos en Urbanismo, el POT/ GAM fue blanco de críticas severas (Soto, 2012). La propuesta al ser analizada a profundidad, presentaba en forma y contenido aspectos incoherentes de enfoque teórico-metodológico. Una de esas críticas, fue la poca socialización que se le dio a la propuesta entre los diferentes actores políticos, sociales y económicos. Otra deficiencia, se evidenció en el reglamento de zonificación, que mostraba una gran complejidad por la cantidad de zonas dispuestas; mientras que la norma gráfica (es decir el mapa de zonificación) no proporcionaba elementos de identificación de las zonas, sub-zonas y casos particulares. Aunado a esto el POT/GAM confunde el reglamento regional con un reglamento de zonificación local, especialmente cuando una norma de carácter regional define aspectos normativos específicos como parámetros urbanísticos. Es decir, existe una invasión a las competencias municipales, lo que al final dio al traste con esta iniciativa.

\section{El Plan GAM 2013-2030}

El fracaso del PRUGAM y el POT/GAM por no concretar una propuesta del ordenamiento territorial en el Gran Área Metropolitana, se define por medio de un convenio institucional entre el MIVAH- ITCR del 6 de mayo del 2013 y CNFL-ITCR del 13 de mayo del 2013, que estas instituciones iniciarían las gestiones para formular un nuevo proceso mediante la Secretaria Técnica del Plan Nacional de Desarrollo Urbano (2013). El propósito era construir una nueva propuesta de ordenamiento territorial a partir de la información generada de los estudios técnicos, planteamientos y recomendaciones de los planes anteriores. A esta propuesta se le denomina el Plan Regional de Ordenamiento Territorial de la Gran Área Metropolitana, Plan GAM 2013-2030.

El Plan establece tres grandes zonas o macro zonas, con sus respectivas subzonas. A su saber se clasifican en: 
1. Macro Zona de Protección y Preservación

2. Macro Zona de Producción Agropecuaria Se subdivide en:

a) Zona de Recuperación Urbana

b) Zona de Centralidades Periféricas: ${ }^{11}$

3. Macro zona Urbana: Se subdivide en la zona dentro del Anillo de Contención Urbana y la Zona de Crecimiento Restringido.

Esta propuesta de zonificación ya oficializada y publicada en el diario oficial La Gaceta en el Decreto Ejecutivo No. 38334-PLAN-MINAE-MIVAHMOPT-S-MAG. Con su oficialización, se mantienen antiguas competencias y se establecen nuevas obligaciones a las instituciones gubernamentales implicadas, que deben gestionar el Plan o que tienen que realizar acciones de control, regulación o supervisión de las zonas establecidas. El reglamento del Plan GAM 2013-2030, si bien formaliza algunos lineamientos en temas como la cesión de áreas y de los conflictos de la zonificación, estos se desarrollan de manera muy breve y no garantiza la operacionalización de procedimientos. Además, la zonificación no se vincula o relaciona con la viabilidad ambiental regional, en la que se supone se basa el Plan.

Se debe señalar que el Decreto Ejecutivo 38334-PLAN-MINAEMIVAH-MOPT-S-MA, tiene interpuesta una acción de inconstitucionalidad parcial en los artículos $25,{ }^{12} 35,{ }^{13} 39^{14}$ y $69,{ }^{15}$ en el expediente 14-019525-0007CO, desde el 18 de diciembre del 2014. En la acción se señala que estos artículos son contrarios a los artículos 21, 50, 89 y 169 de la Constitución Política, así como a los principios de no regresión, objetivación, progresividad, razonabilidad y proporcionalidad, y al derecho a un ambiente sano y ecológicamente equilibrado. Aún se espera la resolución de la Sala Constitucional.

\footnotetext{
11 También definidos como Centralidades Densas Integrales Periféricas (Cuadrantes urbanos).

12 Principios del modelo urbano territorial.

13 Procedimiento para la modificación del anillo de contención urbano.

14 Balance regional.

15 Zonas de recarga acuífera.
} 


\section{Sobre las violaciones del reglamento de zonificación en Costa Rica}

Un gran número de conflictos se pueden evitar desde la etapa de diseño de los reglamentos. Es necesario incorporar los mecanismos en los que opera el mercado inmobiliario, así como las relaciones entre las organizaciones y las comunidades. No conceptualizar esos procesos, significa no entender como el espacio urbano es construido.

Para las autoridades locales el reglamento de zonificación debe ser un recurso flexible que pueda manejar aspectos no contemplados o impredecibles del territorio. De otra manera haría al instrumento incapaz de adaptarse según las diferentes necesidades. La regulación puede ser ajustada entre reglas no negociables y fuertes limitaciones o reglas más permisivas y adaptativas. En cualquier caso, este balance debe realizarse con precaución, para evitar las contradicciones en el articulado, pero contingente al comportamiento de los actores interesados.

El rechazo reiterativo a los códigos o reglamentos de zonificación por parte de los administrados es algo común. En muchas ocasiones, se escucha a los propietarios decir "nadie puede imponer reglas sobre su propiedad", por lo que constantemente se lesiona el carácter jurídico vinculante de un reglamento de zonificación, bajo está argumentación. Incluso el Gobierno Central y sus instituciones autónomas no respetan los códigos municipales, lo que no es un buen precedente. Al menos en el caso costarricense la misma ley 4240, establece en su artículo 17 el principio de legalidad de una zonificación, que en un extracto indica: "[...] que después de ser aprobada una zonificación, el mismo se convierte en un instrumento de carácter jurídico vinculante".

Además, su modificación solo puede ser realizada por medio del mismo procedimiento por el cual fue aprobado, y que también se estipula en la misma ley. Dadas sus propiedades claramente establecidas, la zonificación debe respetar el ordenamiento jurídico establecido, así como seguir las recomendaciones de los criterios emitidos en reportes técnicos o en investigaciones científicas.

La mediación entre los conflictos zonales, es otro aspecto que no se desarrolla en los reglamentos y fomenta las violaciones a la normativa. Es más fácil adoptar por parte de los administradores del territorio una posición inflexible, generando reglas rápidas a cada problema particular. Con el paso del tiempo, este tipo de abordaje, lo que hace es solo engrosar los códigos y 
reglamentos; que al fin de cuentas solo dificultan su aplicación, y peor aún, nunca resuelven los problemas de fondo.

\section{Lecciones aprendidas}

Con la experiencia técnica adquirida por la Escuela de Ciencias Geográficas de la Universidad Nacional, se ha constatado en varias ocasiones ${ }^{16}$ recurrentes características en las normativas de regulación del uso de la tierra, y que se discuten a continuación.

En los centros urbanos que presentan un desarrollo rápido, la mayoría de los reglamentos de zonificación promueven la expansión y el desarrollo lineal, lo que suele estar en conflicto directo con los objetivos y las metas de un plan regulador urbano, que tratan de consolidar los centros existentes y la preservación de los paisajes rurales. La mayoría de estos códigos evitan la construcción o regeneración de las centralidades urbanas, que curiosamente son anteriores a la zonificación.

Las más importantes decisiones sobre el uso de la tierra son realizadas por modificaciones y ajustes a la zonificación, que no siguen el procedimiento legal establecido. Debido a que en varias ocasiones lo que aparentemente son situaciones de sentido común, no fueron consideradas en el diseño o propuesta técnica. En el peor de los casos, se busca oficializar usos incompatibles o ilegales mediante adendas o anexos. Considerando, que una modificación de este tipo, es primero un esfuerzo tedioso y laborioso, al fin de cuentas puede ser infructuoso por las condiciones en las que se presentan las anomalías a legalizar. Es mejor considerar un abordaje más integral, mediante la actualización del Plan Regulador bajo proceso ordinario, tal y como lo estipula la legislación costarricense.

Se ha observado, que incluso las mismas autoridades de los gobiernos locales buscan invalidar de manera total o parcial la herramienta local de planificación, por aparente falta de criterios técnicos o sugieren anomalías administrativas de forma en la de aprobación del instrumento regulador. Esto

${ }^{16}$ De la participación en la elaboración y actualización de Planes Reguladores en los cantones de Escazú, Poás, Siquirres, Esparza, Atenas, Upala, Los Chiles, Guatuso y Santa Bárbara. Así como del estudio de caso, la revisión de informes técnicos o de reglamentos urbanos de otros cantones de Costa Rica. 
con el fin de reestructurar o modificar la reglamentación vigente en el territorio, en beneficio propio o de cercanos.

Además, la norma gráfica, es decir el mapa de zonificación, no es lo suficientemente claro y tiene deficiencias en su representación cartográfica, ya sea en los elementos formales o en los de fondo como la delimitación espacial de las categorías y la tabla de parámetros urbanísticos. Esto confunde al administrado en el momento que necesita obtener un servicio o trámite municipal. En el caso de los administradores, se traduce en un tiempo de respuesta administrativa más prolongado. También puede significar en una inaplicabilidad del instrumento y el trámite de frecuentes consultas o criterios técnicos para responder a los usuarios municipales. En términos generales, se pierde efectividad y eficiencia en la gestión territorial y que como consecuencia final genera inseguridad jurídica en los propietarios.

Es así, como una gran cantidad de administrados violan los reglamentos de zonificación de manera regular con impunidad, al realizar actividades inocuas que no molestan o afectan a nadie; pero que requieren un alto costo administrativo por parte de los gobiernos locales en su atención. En todo caso, se puede concluir que el abordaje más utilizado en la regulación urbana es el de prueba y error, que se evidencia en como los enfoques alternativos de zonificación se originan, es decir del análisis de los resultados empíricos.

Sin embargo, a pesar de que este proceso constructivista no es muy buen visto por un grupo de académicos, especialistas de diversas disciplinas y ciudadanos en general; esta ha sido una respuesta pragmática, al entender que la dinámica urbana sobrepasa la capacidad de gestión que tiene la misma sociedad sobre los espacios que habita y transforma.

\section{Referencias}

ALFARO-RODRÍGUEZ, D. y ALFARO-RODRÍGUEZ, L. C. Gestión de Planes Reguladores en Costa Rica. Heredia, 2004.

ARRIETA-CHAVARRÍA, O. "Ordenamiento Territorial y Planes Reguladores: Notas al margen de nuestra experiencia en la ECG-UNA”. Revista Geográfica de América Central, v. 1, n. 44, pp. 75-90, 2010.

BADILLA, A. et al. Análisis Plan GAM 2008-2030. San José, 2009. 
BARRANTES-SOTELA, O. E. et al. "Procesos de Crecimiento y Renovación Urbana en Santa Bárbara de Heredia. Costa Rica, 2014”. Revista Geográfica de América Central, v. 2, n. 55, pp. 69-93, 2015.

BENABENT, M. “Teorías de la planificación territorial: métodos de decisión”. Ciudad y Territorio - Estudios Territoriales, v. XLVIII, n. 189, pp. 353-68, 2016.

CARAZO, E. "Esquemas de zonificación ambiental para la planificación regional urbana”. Revista Geográfica de América Central, v. 1, n. 41, pp. 55-73, 2011.

CGR. Informe acerca de la gestión del Instituto Nacional de Vivienda y Urbanismo en la implementación del Plan Nacional de Desarrollo Urbano. San José, 2012.

CUNNINGHAM, C. R. Uncertainty, zoning and land development. Syracuse University, 2005.

DISPENSA, J. M. Separation of use or misuse: multifaceted empirical study of zoning variances. Drexel University, 2004.

DORANTES, C. y NETTEL, A. del C. "Urbanismo sustentable en la Unión Europea, claves de su regulación normativa”. En LÓPEZ, S. e FERNÁNDEZ, J. (Eds.). Derecho Urbanistico, 1 era., pp. 31331). Universidad Autónoma de México, 2011.

DOWNS, A. "Growth management, smart growth, and affordable housing”. 2003

ENTIDAD GESTORA DEL PROYECTO PRUGAM. Plan Regional Urbano de la Gran Area Metropolitana de Costa Rica - Tomo I: Diagnóstico Plan PRUGAM. San José, 2008.

EXNER, M. e R., S. Performance-based planning model for the town of Morinville. Edmonton: Steppingstones Partnership, Inc., 1996.

HAMOUDI, H. y RISUEÑO, M. "The effects of zoning in spatial competition". Journal of Regional Science, v. 52, n. 2, pp. 361-74, 2012.

HARPER, T. et al. Dialogues in urban and regional planning. Taylor \& Francis, 2008.

JENKINS-DOBLES, E. Ordenanza de zonificación. San José, 1969. 
JOHN A. HUMPHREYS ASSOCIATES. The code of development-twenty-five years after. Breckenridge: John A. Humphreys Associates, 2002.

KENDIG, L. y CONNOR, S. Performance zoning. Chicago: Planners Press, 1980.

KOLNICK, K. A. Order beforezoning: land useregulation in \{Los Angeles\}, 1880-1915. University of Southern California, 2008.

MASSIRIS-CABEZAS, A. "Bases teórico-metodológicas para estudios de ordenamiento territorial”. Revista del Instituto de Desarrollo del Distrito Capitaly la Participación Ciudadana y Comunitaria IDCAP, v. 2, n. 2, pp. 43-87, 1993.

MATEO-RODRÍGUEZ, J. M. “Geografía y planificación territorial”. Entorno Geográfico, n. 10, pp. 8-31, 2014.

MORA-RAMÍREZ, J. Análisis del crecimiento urbano de la Gran Área Metropolitana de Costa Rica, periodo 1983 al 2000. Universidad de Costa Rica, 2003.

. Plan Regional Metropolitano GAM (Versión di). San José, 2006.

y ACUÑA-ARAYA, L. F. Informe de cierre como representantes del INVU ante proyecto PRUGAM. San José, 2009.

NELSON, A. C. "The link between growth management and housing affordability", pp. 1-56, feb. 2002.

OBANDO, F. J. "Planificación urbana sostenible en Costa Rica”. En LÓPEZ, S. e FERNÁNDEZ, J. (eds.). Derecho Urbanistico. 1 era. Universidad Autónoma de México, 2011, pp. 187-99.

PORTER, D. R. Growth management: kepping on target? Washington: Urban Land Institute with the Lincoln Institute of Land Policy, 1986.

RAMÍREZ, A.y VILLALOBOS, M. L. Marco normativo, institucionaly conflictividad del ordenamiento territorial. San José, 2014.

ROMAIN, M. "Zoning and urban development control". European Network for Housing Research 2013 conference: overcoming the crisis. Tarragone: HAL, 2013. 
SCHMIDT, S. y BUEHLER, R. "The Planning Process in the US and Germany : a comparative analysis the Planning Process in the US and Germany : a comparative analysis". International Planning Studies, v. 12, n. 1, pp. 55-75, 2007. http://doi. org/10.1080/13563470701346592.

SECRETARIA TÉCNICA PLAN NACIONAL DE DESARROLLO URBANO. Plan GAM 2013: Propuesta Operativa y Avance Técnico. San José, 2013.

SOLOW, A. A. Proyecto para el Desarrollo Urbano de la Capital de Costa Rica. Washington, 1949.

SOTO, E. ¿Cuál es el futuro del ordenamiento territorial en el Área Metropolitana? El Financiero, 2012.

TÜRK, Y. A. et al. "Evaluating the developmental process of the zoning regulations in Turkey in terms of urban design. International Journal of Academic Research, v. 3, n. 1, pp. 580-84, 2011.

UNIDAD DE PLANIFICACIÓN TERRITORIAL. Informe Final de Revisión de la Propuesta de Actualización del Plan Regional de la Gran Area Metropolitana (GAM 1982). San José, 2010.

VAN WIJK, M. et al. "Exploit or protect airport regions from urbanization? Assessment of land-use restrictions in Amsterdam-Schiphol". European Planning Studies, v. 19, n. 2, pp. 261-77, 2011. http://doi.org/10.1080/09654313.2011.532671.

WARREN, C. Designed by zoning: evaluating the spatial effects of land use regulations. University of California, Berkeley, 2009. 


\section{Esbozo con perspectiva geográfica de los estudios sobre la ciudad, el espacio y las cuestiones urbano-regionales en América Latina}

Omar Arrieta Chavarría

\section{Introducción}

Este capítulo da cuenta a partir de las publicaciones que se han realizado principalmente en la última década en diversos círculos académicos de América Latina, delos estudios relacionados con: a) la ciudad y las cuestiones urbanas; b) el urbanismo y la planificación; y c) La cuestión urbano regional y el ordenamiento del territorio. Esto con el objetivo de comprender las experiencias logradas en esta materia, aprender de ellas, y quizás, en algunos casos, reorientar y fortalecer la producción científica sobre estos temas particularmente en Centroamérica que es desde donde trabajamos los asuntos que aquí se expondrán. ${ }^{1}$

Metodológicamente, primero se identificaron, algunas instituciones que se destacan por su trayectoria en el campo de la investigación científica y técnica en la temática. La tabla 2 (en el anexo) da cuenta de aquellas instituciones consultadas a través de sus páginas en internet. Los centros académicos que

\footnotetext{
En cuanto a Centroamérica las publicaciones científicas sobre cuestiones urbano- regionales han sido de interés intermitente. Las investigaciones se han desarrollado con alguna periodicidad en ciencias sociales desde la década del setenta en cuestiones regionales, planificación urbana, o el sistema de ciudades. En la última década ha habido un mayor interés por desarrollar proyectos institucionales e impulsando trabajos de graduación en maestrías y doctorados en este campo a través de algunas universidades y facultades centroamericanas. Para esta publicación se consultaron, entre otros, los trabajos de Baires (2006); Flores (2009); Morán (2007, 2011a, 2011b); Pérez (2006); Séguin (2006).
} 
se ocupan de estos problemas son numerosos y sólo se incluyen algunos para sintetizar las líneas de trabajo que en ellos se impulsan. En cuanto al caso brasileño, que constituye una realidad aparte por el extraordinario desarrollo de instituciones públicas y privadas en la enseñanza, la investigación aplicada y la divulgación de estudios de este tipo, esta fuera de nuestras posibilidades conocer en su totalidad el aporte que han hecho en este campo de los estudios espaciales. Sin embargo, para realizar esta investigación se consultó una muestra significativa, pero absolutamente incompleta, de universidades, departamentos e institutos brasileños que se dedican al análisis científico y técnico de estos temas generales.

Posteriormente se procedió a la revisión detenida de los artículos y textos que aparecen en las referencias al final de este capítulo y que, por razones de espacio, representan solo una parte, una muestra al azar, de la extensa producción que desde diversas disciplinas se genera en lo que a juicio nuestro son líneas fundamentales de la investigación en esta materia en Latinoamérica.

El análisis de cada tema se realiza respaldado en la revisión crítica de las fuentes desde una óptica disciplinaria, que enfatiza en la cuestión urbana y el territorio y desde los diferentes abordajes que presentan los textos consultados, siguiendo las clave que nos ofrecen los artículos escritos en los últimos diez años por autores latinoamericanos.

Finalmente, después de las consultas y revisión de los textos seleccionados, se identificaron los grandes temas que en ellos predominan ${ }^{2}$ y que forman parte del corpus de este artículo.

Para efectos de exposición, el texto se ha dividido en tres acápites, en el primero de ellos se hace un ligero repaso de algunos aportes teórico metodológicos sobre el tema fundamental del artículo, vale decir, la ciudad y el espacio urbano regional vistos desde la geografia; la segunda sección es una revisión más restringida a las cuestiones urbano-regionales y una síntesis de los temas más recientes en el ámbito de la geografía con enfoques posmodernos y socio críticos; la tercera sección del artículo ligada a las conclusiones, es una reflexión final de los aportes y posibilidades futuras en las investigaciones de este tipo con miras a enfrentar los retos que se tienen en el campo de las ciencias sociales vinculadas al análisis del espacio geográfico, la ciudad y la cuestión regional, asuntos que interesa profundizar en el caso centroamericano.

2 Ver la interpretación en el gráfico 1 de este capitulo. 


\section{Interpretación de algunos aportes teórico-metodológicos sobre la ciudad, el espacio y las cuestiones urbano-regionales con perspectiva geográfica en América Latina}

La propuesta positivista, de una realidad única que funciona de acuerdo con leyes naturales de causa-efecto y pretende explicar, predecir y controlar "los hechos", es dominante en los estudios de la ciudad, el urbanismo y las cuestiones urbano-regionales en nuestro continente. Dominante, desde el punto de vista de la teoría y el ejercicio del poder, es decir, desde la producción científica estructural funcionalista y tecnoburocratica que domina la ciencia y la investigación aplicada de los aparatos del Estado. O a través de los esfuerzos que se hacen en institutos o programas de investigación que impulsan la nueva geografía cuantitativa fundamentada en los sistemas de información geográfica (Buzai, 2003). Este tipo de investigaciones se ven complementados por abordajes sobre temas urbanos aun con influencia de la escuela de ecología humana de Chicago enriquecidos con conceptos categoriales que aporta el pensamiento complejo, ${ }^{3}$ como los de "nicho ecológico", "ecología urbana", o "ecosistemas urbanos" y recurren metodológicamente a la zonificación del espacio relacionando criterios demográficos, ecológicos y sociales. Por ejemplo, Los estudios aquí consultados en esta línea para las ciudades de México (Annick y Polèse 1994), Germain y Polèse (1996), utilizan variables demográficas, y tablas relacionadas con información sanitaria y de servicios como agua potable y otros para definir zonas urbanas.

En muchos casos se recurre a los datos censales, las encuestas y la cartografía urbana especializada, e información proveniente de las tecnologías satelitales y la red de internet. Algunas investigaciones utilizan el concepto de ciudad ecológica o "ecociudad" para diseñar una estrategia de investigación que concibe la ciudad como un "nodo" de ecosistemas por el cual fluye y se intercambia energía. Las urbes son vistas como sistemas abiertos por el que

3 Diferenciamos dentro de lo que hoy se definen como "estudios o teorías de la complejidad" aquellos que parten de la idea pura y dura de una complejidad sistémica funcionalista, que deposita su confianza en las estructuras científico tecnológicas al servicio de las políticas del mercado capitalista globalizado, de teorías de la complejidad fundadas en el pensamiento reflexivo, que se originó con la crítica a la economía política del siglo XIX y se ha enriquecido del desarrollo de la ciencia en general, de la teoría de la relatividad, la física cuántica y de la física teórica de los siglos XX y XXI. 
entran y salen poblaciones, mercancías, insumos y redes de infraestructura que les dan "vida" (Barkin, 2015; Henríquez, 2005).

En cuanto a publicaciones relacionadas con lo que tradicionalmente se conoce como estudios de la jerarquía urbana, la investigación ha evolucionado hacia el análisis de redes espaciales urbanas o regionales dentro de la teoría de los espacios virtuales, en el que las ciudades se comportan como nodos de los circuitos de transferencias de capital, de personas, mercancías y tecnologías que se estructuran según las formas que estratégicamente ocupan en el proceso de acumulación reciente creando nuevos flujos de interconexión entre ciudades, de acuerdo con, por ejemplo, nichos de mercado o circuitos de circulación de mercancías especializadas (Ver, entre otros, los estudios de Davis y del Cerro, 2009; Montoya, 2006, 2009; Rodríguez, 2006; Usach y Garrido, 2008). Y en otros casos con un enfoque positivista sistémico en el marco de las nuevas geografías cuantitativas antes mencionadas.

Las investigaciones clásicas en geografía urbana siguiendo el constructivismo hermenéutico y la fenomenología están influenciadas por los trabajos de la percepción o la imagen de la ciudad de Kevin Lynch. Enfoque con el cual metodológicamente se analiza la vinculación que existe entre las imágenes mentales y el grado de identificación que los habitantes tienen con su ciudad através de los recorridos diarios por ella (Guerrien, 2005; Iregui, 2005; Serrano, 2015). De esta manera, el investigador interpreta la información tratando de encontrar claves que ayuden a comprender la manera en que las personas suelen aprehender el espacio que les rodea. Los mapas mentales reflejan deformaciones de percepción del entorno que pueden ser resultado de factores tales como la educación, edad, sexo, clase socioeconómica o ideología y estas percepciones y comportamientos de los habitantes de un lugar, se convierten en la base para la interpretación de los procesos urbanos y cómo planificar espacios urbanos (para el caso costarricense ver el estudio de Lidth y Schütte (2010)).

Desde el pensamiento crítico el espacio urbano es el escenario de relaciones socio-políticas conflictivas, cuya apropiación del territorio resulta de las contradicciones de clase y de la división social del trabajo. Es, además, para los que se sustentan en estos enfoques, el producto material y cultural que emerge de las posibilidades, las necesidades y los intereses de los distintos agentes sociales que viven dentro o fuera de la ciudad (Cardoso y Ortiz, 2009; Castro, 2012; Dammert, 2004; Morán, 2011). 
En general estas teorías se sustentan en conceptos y categorías de análisis tradicionales como región, paisaje, territorio, o lugar, pero entendidas como categorías que explican las formas de "representación", de "reproducción" y "construcción social" del espacio geográfico. Se trata pues de reconstruir conceptos o categorías de análisis para comprender, como leyes de tendencia, los procesos que están en la base de las desigualdades espaciales y sociales; vale decir, los procesos de acumulación de capital, la concentración espacial de la pobreza urbana, y la apropiación desigual del territorio, en contextos históricogeográficos específicos (Baires, 2006; Caquimbo, 2008).

Las construcciones teórico-metodológicas que van desde el marxismo clásico, incluyen también los enfoques del Configuracionismo latinoamericano, los estudios con enfoques neomarxistas y las investigaciones urbanas desde la sociología crítica. Procesos como apropiación desigual del espacio urbano, conceptos o categorías como renta capitalista del suelo o condiciones generales para la reproducción ampliada del capital en la ciudad y su entorno, son fenómenos que se estudian en América Latina bajo las formas que adquieren en el capitalismo de hoy. Estos análisis comprenden no únicamente discusiones teóricas, sino también trabajos empíricos, explicaciones del espacio particular, de las singularidades de tales espacios, sin descuidar la interpretación de las formas de acumulación a escala mundial y su impacto en las regiones urbanas del continente.

La producción científica desde el paradigma socio - crítico en general, se desarrolla en algunos casos, con la teoría críticas de la posmodernidad con un fuerte contenido en la lectura de lo urbano como construcción y reflejo de una cultura global, diversa y contradictoria. Estos análisis, cual pequeños relatos de los espacios fragmentados, de las formas de acumulación flexible que incorpora al circuito de la economía y la tecnología fragmentos de las ciudades del tercer mundo, generando grandes contrastes en el paisaje y la economía urbana, recuperan conceptos como el de "espacios rugosos" y "espacios luminosos" o el de "zonas opacas" presentes en toda la obra de Milton Santos ${ }^{4}$ que ya mostraban esos procesos de globalización cultural y tecnológica.

En cuanto a los estudios empíricos de los núcleos urbanos en América Latina, la mayoría de ellos se ocupan de los problemas relativos inseguridad

4 Ver, entre muchos de sus estudios, SANTOS, M. "Los espacios de la globalización". Anales de Geografia de la Universidad Complutense, n. 13, pp. 69-77, 1993. 
urbana, la segregación socio-espacial, la fragmentación del espacio urbano y el auge de los espacios cerrados (ver, entre otros: Cardoso y Ortiz, 2009; Dammert, 2004; Pérez, 2006; Ruiz, 2009).

En fin, los paradigmas, enfoques, conceptos y categorías de análisis utilizados en la teoría investigativa crítica y hermenéutica analizan la ciudad como un producto socio-cultural y tecnológico. En algunos casos desde un enfoque dialéctico, en otros, desde el análisis sistémico y por último, pero no menos frecuente, desde propuestas eclécticas dignas de destacar cuando se procura el análisis reflexivo que desde el eclecticismo teórico hacen de la ciudad. 
Figura 1: Paradigmas, enfoques, conceptos y categorías de análisis predominantes en el análisis de la ciudad y los procesos urbanos. Desde el pensamiento positivista-sistémico y funcionalista a los paradigmas socio críticos

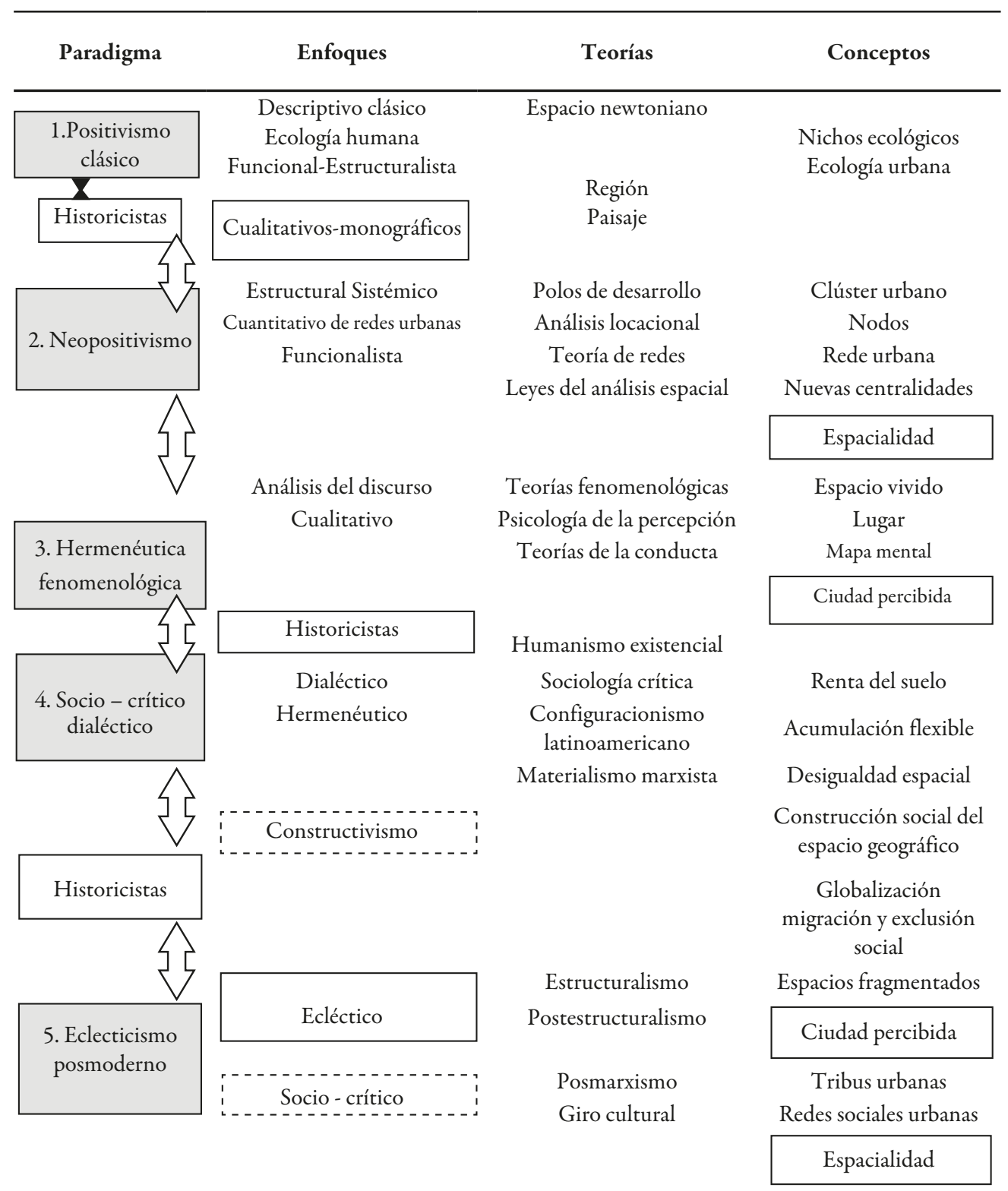

Nota: Los recuadros dan cuenta de propuestas de paradigmas como el historicismo, que aparecen en distintos momentos y desde distintas construcciones teórico-epistemológicas. Lo mismo ocurre con los enfoques o métodos cualitativos y cuantitativos o mixtos y por supuesto con conceptos o categorías de análisis que se utilizan en diferentes paradigmas o enfoques con distintas significaciones. 


\section{La ciudad-región, las cuestiones urbano-regionales y la planificación local desde la geografía en América Latina}

La figura 2 muestra (mediante flechas) las relaciones que en términos de enfoques y contenidos y desde perspectiva geográfica, se encuentran entre las materias de las investigaciones empíricas relacionadas con la ciudad, las cuestiones urbano-regionales, y la planificación local. Lo que se encuentra en la producción académica es un primer grupo agrupado en torno a cuatro temas referidos a: 1. La cuestión Urbano-Regional; 2. Ciudad y Ordenamiento territorial; 3. Planificación Urbana y local y 4. Ciudad y región. Un segundo grupo temático enfatiza en: 5. Ciudades sostenibles y 6 . Urbanismo y ambiente. Luego se encuentra un tercer grupo de temas conexos que incluyen: 7. Urbanismo, desigualdad socio-espacial y fragmentación del espacio; 8. Ciudad, cultura y paisaje urbano; 9. Estudios urbanos con enfoque de Género y feminista, ligado a investigaciones sobre culturas alternativas, migración y pobreza urbana. Finalmente se ubican dos temas separados, uno de vieja data: 10. Espacios metropolitanos y otro más reciente que es el de: 11. Ciudades secundarias e intermedias en América Latina.

Seguidamente se analizarán estos temas desde el marco conceptual aquí definido y desde la investigación empírica en Latinoamérica. Para ello, primeramente, se resumen los conceptos básicos de ciudad y espacio urbano y luego el de ciudad-región, para profundizar después en el análisis de cómo ha sido abordados el asunto de la cuestión urbano -regional propiamente dicho, los temas sobre ciudad y naturaleza, los estudios culturales y alternativos y la cuestión de las ciudades secundarias e intermedias como asuntos de interés reciente en las investigaciones en nuestros países.

\section{La ciudad y el espacio urbano}

A partir de la segunda mitad del siglo pasado, el espacio geográfico en el continente se hizo más diverso, dinámico y complejo con el crecimiento de las ciudades. Se agudizaron los procesos de artificialización de la naturaleza (que ya se habían iniciado durante los cincuenta), y con la expansión acelerada de las aglomeraciones urbanas y conurbaciones se consolidan las grandes metrópolis que hoy dominan los países latinoamericanos. El proceso más reciente de globalización ciertamente presenta otras características: cuarta revolución tecnológica y globalización de todas las mercancías habidas y por haber. Pero 
la pobreza y las desigualdades sociales en las urbes se han agudizado en las últimas décadas, en el período más comúnmente conocido como la "era de la globalización". Los informes oficiales y no oficiales nacionales e internacionales sobre el continente así los reconocen.

El abordaje de la ciudad ha significado valorar el análisis espacial del comportamiento de algunas variables: Déficit habitacional y hacinamiento. Déficit en la integración social de la población, especialmente de la población marginal que continúa siendo excluida del mercado y en general del sistema económico "formal". Déficit en el diseño, establecimiento y prestación cualitativa de servicios mínimos necesarios para el mantenimiento de indicadores de sanidad y morbilidad satisfactorios. Inadecuada planificación urbana, y otros.

Desde la década del setenta hay interés por parte de los países en atender el problema ambiental en general y particularmente en las urbes. Después del Informe Brundtland (1987), proliferaron los estudios para abordar los problemas ecológicos y ambientales asociados al crecimiento urbano del planeta. En el continente Latinoamericano y el grueso de naciones no hispanoparlantes de esta región se ha incrementado sustancialmente la población urbana al punto de que hoy cerca del $80 \%$ de las personas de esta parte del globo viven en ciudades y es la zona más urbanizada del mundo (ONU-HABITAT, 2012).

La confrontación de opiniones en la producción académica y científica del continente pone también en la palestra la cuestión entre calidad del hábitat y desarrollo caótico de la ciudad latinoamericana. Enfrenta, de alguna manera, esta polémica, la esencia que está en la base de la construcción de ciudades más humanizadas, salubres, equitativas, social y políticamente participativas justas y responsables con el soporte físico natural sobre el que se erigen tales conglomerados, frente a la idea de que una ciudad se ordena a partir de las necesidades y de las exigencias del mercado capitalista y la rentabilidad del suelo. Evidentemente estos parámetros ponen en jaque a los urbanistas y al urbanismo como práctica social y técnica. La planificación en función de la sociedad, las prioridades en el ordenamiento de los asentamientos humanos en función de los grupos sociales objetos-sujetos de estas políticas, la cuestión de la vivienda de interés social frente a la renta capitalista del suelo urbano, la desaparición de los barrios y el impulso a las ciudades amuralladas, la deshumanización del espacio urbano, la fragmentación y el mundo del consumo privado de los espacios públicos, el aislamiento y la soledad en la selvas de 
hierro y cemento que benefician al capital, la ruptura y amenaza de las áreas protegidas que se encuentran en el hinterland de estas aglomeraciones urbanas, son cuestionamientos que se abordan desde distintos ángulos o enfoques en la bibliografía consultada al respecto.

Los indicadores para el estudio de sostenibilidad urbana ayudan a diseñar políticas para la implementación de un desarrollo sostenible en un área específica. En este caso el enfoque varía con respecto al análisis de procesos urbano-regionales. El punto de partida en los estudios de sostenibilidad es también una Ecología del Paisaje de origen sistémico, pero con un abordaje que enfatiza en la calidad de vida a escala urbano regional y territorial. De ahí que se trabaje con las categorías de territorio, región, paisaje natural o paisaje ecológico, relacionados con los problemas de la sostenibilidad del entorno urbano cuando se procura recuperar los corredores biológicos, o estudiar la importancia de las áreas protegidas y los parques naturales, para mantener la vida en ciudad y la región. El reto fundamental aquí es cómo resolver la contradicción entre la expansión urbana, los usos artificiales del suelo frente a la necesidad de proteger y mantener vivos los ecosistemas naturales y sus bondades.

\section{La región}

El concepto de región se convierte en una categoría de análisis en el marco teórico metodológico de las nuevas geografías regionales que ven el mundo como un espacio en redes, y heredan de la escuela clásica francesa la idea de región como objeto de estudio de la geografía. Esta idea de región (newtoniana) está presente en esas geografías aplicadas de corte positivista, integradas orgánicamente a los aparatos de dominación de un Estado que promueve una planificación tecnoburocratica del espacio, a través, por ejemplo, de los planes de ordenamiento territorial.

Por otro lado, las investigaciones que analizan la región bajo categorías del pensamiento complejo, que se enfocan en estudiar los flujos de energía, los espacios flexibles, o los ciberespacios, asumen que la tecnología es el agente transformador de la sociedad, del territorio, y del espacio físico- natural, y convierten a los procesos científico- técnicos en el "agente" que no solo vincula a la sociedad con la naturaleza, si no que de manera fetichizada explica y da soluciones a los problemas socio -ambientales del planeta (Toudert y Buzai, 2004). 
Losestudios sobre el espaciogeográfico como-región-territorio-paisajelugar van desde aquellos en los que este es concebido como región mensurable $y$ delimitada como ocurre en las posiciones clásicas, hasta el espacio relativo de la física de hoy. Otros análisis conciben la región geográfica desde una visión estructural funcionalista, o fenomenológica del espacio - lugar - paisaje vivido o percibido. En este último caso, la región deja de ser región para convertirse en territorio (como terruño), en paisaje, en el lugar, se trata de interpretaciones historicistas, humanistas, y de la percepción. Es el espacio vivido, y el paisaje es la expresión visual, instantánea, la sucesión de acontecimientos, la disposición de los objetos en un instante del espacio tiempo geográfico (Iregui, 2005) que se alejan de las concepciones nomotéticas para ubicarse dentro de una visión idiográfica de la ciencia, del paisaje, del terruño, del lugar.

\section{La ciudad-región}

No todo lo que ocurre en la ciudad o en las metrópolis está ligado a la red mundial, también se fragmenta la ciudad por la propia estructura interna del mercado capitalista nacional, que establece alianzas estratégicas con ejes de acumulación inter regional para enfrentar al capital hegemónico transnacional. ${ }^{5}$ Muchos de los nuevos distritos financieros, las nuevas superficies comerciales, las industrias que se dispersan en el tejido urbano, son producto de la alianza de capitales nacionales o de alianzas entre capitales de la región. De tal manera que los procesos de fragmentación socio espacial del espacio por la participación de capitales diversos hace más compleja la trama urbana. Y todo esto hace posible que los ciudadanos, sin duda, vivan o sobrevivan de forma desigual en la ciudad: unos mejoran su calidad de vida (los ciudadanos más articulados a los circuitos de la alta productividad obtienen los mayores beneficios totales que genera la nueva vida urbana), otros se reproducen de las economías

5 En Centroamérica es muy claro el rol que están jugando las élites empresariales de la región en este proceso de crear conglomerados de inversión conjuntamente para competir con las empresas transnacionales lo cual ha modificado aceleradamente el paisaje urbano en las últimas décadas. Las inversiones de los capitales de la región en alianzas estratégicas son notorias en el sector inmobiliario, los complejos comerciales, líneas hoteleras, condominios y otros del sector construcción y alimentario. Hay una respetable bibliografía de la última década en este campo que por razones de espacio no es posible comentar. Puede consultarse al respecto el estudio de Robinson (2007) para iniciarse en este tema. 
informales en los espacios periféricos y en los intersticios de la urbe que acoge las grandes inversiones. De esta manera, el fenómeno urbano de hoy, por la coexistencia de los opuestos concentración-periferización- dispersión, que cambia constantemente de jerarquía y nivel, que mediante los nodos urbanos internacionales producen vinculaciones interactivas en red, separa el espacio urbano de sus habitantes. Es decir, el proceso de integración global fragmenta a la ciudad social y espacialmente y la ciudad de hoy es más segregada que nunca y tiende a ser una ciudad-región

De ahí que los estudios en las Universidades e institutos han dirigido la mayor parte de sus investigaciones hacia estos temas centrales para entender la situación desigual del desarrollo urbano en el continente, pero también en procura de plantear alternativas posibles al llamado maldesarrollo.

Las investigaciones latinoamericanas en este campo van desde aquellas que conciben el espacio como sinónimo de región mensurable, como espacio absoluto, pero, paradójicamente, de-limitado, tal y como ocurre en los estudios clásicos de la geografía, hasta estudios más contemporáneos que parten de un análisis geográfico desde la relatividad espacial.

A partir de los años noventa crece y se concentra la pobreza en el planeta, el proceso de globalización neoliberal exige mayor competitividad, productividad y eficiencia de las economías subordinadas al capital transnacional y la vida de la sociedad en su conjunto tiende a perder calidad y en el entorno urbano y sus zonas de influencian se agudiza el deterioro ambiental. Aumentó la preocupación por la pobreza y la desigualdad social, los recursos naturales y la degradación ecológica. Surge el interés en círculos políticos por impulsar los programas de planificación urbana y el ordenamiento territorial. Se elaboran diagnósticos totales, teorías sustantivas, metodologías participativas novedosas, modernas tecnologías que buscan reinterpretar la dinámica urbana, procuran recuperar la ciudad, su entorno, los ecosistemas, pero siguen sin solucionarse las graves contradicciones de las aglomeraciones urbanas: escasez de servicios públicos, degradación de los ecosistemas urbanos, pobreza y exclusión social, hacinamiento, segregación, y criminalidad e inseguridad.

\section{La cuestión urbano regional propiamente dicha}

Comprender la relación entre urbanización y crecimiento económico obliga a identificar los procesos diferenciados del desarrollo del sistemas de ciudades no sólo para entender el proceso de metropolización en el continente 
o el fenómeno de las aglomeraciones urbanas a escala nacional, sino porque es imposible realizar un estudio certero de los procesos geográficos sin reconocer que lo metropolitano y lo urbano no pueden ser analizados separados de la dinámica que asumen los procesos de acumulación y sin tener presentes las tendencias históricas tanto en las prácticas agrícolas y en las estructuras productivas rurales en general como en los sistemas de ciudades, a raíz del uso generalizado de las tecnologías duras en actividades propiamente urbanas pero también, fruto de las alteraciones que sufre el espacio físico-natural una vez que se desarrollan las urbes; vale decir, alteraciones de las cuencas hidrográficas, trastorno en las aguas superficiales por asfaltado y compactación del suelo, sobreproducción de desechos sólidos e incapacidad de absorción de los mismos, solo para mencionar algunos ejemplos de las investigaciones consultadas.

El proceso de urbanización, el crecimiento desigual y diferenciado del sistema urbano y el espacio en que esto ocurre, se plasma espacialmente en la aparición de los núcleos urbanos y sus áreas de influencia, en los espacios rurales, en la protección o no del medio ambiente, en los usos adecuados o inadecuados del suelo, en la recuperación o empeoramiento de los espacios degradados, productos, todos, en última instancia, del modo de producción dominante en un Estado particular; es decir, en una formación socio política de un país. A este conjunto entreverado de hechos, productos o resultados, generales y específicos, particulares y singulares que acontecen en el espacio geográfico, es lo que aquí llamamos la cuestión urbano regional en plural por ser acontecimientos diversos y complejos.

Los estudios sobre la cuestión urbano regionaly planificación local como dimensión científico técnica del espacio-territorio y los retos que esta conlleva cuando se proponen "modelos" o "alternativas", cuyo fin es mejorar la calidad de vida de las personas es un asunto que no está separado de la idea de desarrollo de la que se parte para emprender esos retos y que en el fondo están vinculados al problema del poder y las formas de acumulación de capital en economías de mercado.

La cuestión urbano regional es entendida en los textos consultados no sólo como un enfoque científico que considera los procesos espaciales a partir de formas y contenidos con que históricamente surgen los espacios urbanos y las regiones con el desarrollo de las actividades económicas, del mercado, y de la red de circulación de mercancías; sino que además, hoy estas pesquisas incluyen la cuestión ambiental (desde el marco teórico de la ecología política), 
las relaciones de clase, las contradicciones inter étnicas, el enfoque de género, y de nuevo, las particularidades que asume el proceso de acumulación de capital a escala mundial y su dinámica de crisis y recomposición a través de lo que Harvey ha dado en llamar acumulación por desposesión.

\section{Las leyes de planificación local en un mundo global}

Junto a los estudios urbano-regionales desde los enfoques críticos, aparece también una buena cantidad de publicaciones que abordan la cuestión técnica del ordenamiento, incluyendo metodologías específicas para los estudios científicos, el aparato jurídico normativo y la cuestión políticoadministrativa Stricto sensu. Esto por cuanto entre el espacio geográfico y su construcción, media el mercado capitalista y lo jurídico. La mediación entre el espacio geográfico como territorio y los procesos normativos se realiza a través de la administración y la gestión. En el ejercicio de gobernar surgen los grandes problemas de lo público y lo privado y de la práctica autoritaria del poder y el uso democrático del espacio. La bibliografía en este campo pone el énfasis en las dificultades y el potencial que tiene la planificación urbana y local cuando se está frente a Estados autoritarios o centralistas sobre todo si se trata de países pequeños como los centroamericanos.

Estos análisis son indispensables para la comprensión del problema complejo que significa ordenar, gestionar o planificar el territorio en cualquier geografía. Es la base científica, inevitable, si se quiere estructurar científicamente el territorio. ${ }^{6}$ Es aun problemático en ciertas regiones del continente definir las competencias y funciones que garanticen una administración justa e inclusiva socialmente, equitativa, equilibrada desde los ecosistemas, redistributiva y solidaria económicamente, a escala nacional, regional y local, en este sentido está claro que el espacio en una formación social solo está delimitado por el ámbito en el que se ejerce el poder; luego, los procesos de construcción del espacio, se expresan en acciones y mediaciones

6 Los agentes sociales elaboran las estructuras espaciales, definen los territorios, los paisajes artificiales al actuar en la naturaleza para bien o para mal, la erosionamos o la regeneramos, aprendemos o desaprendemos de ella, vivimos nos reproducimos y sobrevivimos en ella. Luego las estructuras elaboradas comienzan a definir nuestro destino, nos atrapan, nos alienan, las fetichizamos y finalmente, cuando ya no hay alternativa, nos revelamos contra los actores hegemónicos y contra ellas para elaborar nuevas estructuras espaciales. Y así, la geografía, marcha con nosotros por la vida. 
que tienen diferentes escalas: La escala nacional tiene mayores competencias cuando se trata de gestionar la red nacional de transporte, las redes de flujos energéticos, las redes de comunicación y otras. La escala regional, está asociada a la administración de los recursos naturales y de los ecosistemas, por ejemplo las fuentes y la red hidrológica, o los sistemas urbanos regionales; y a escala local, evidentemente, lo más notable es la administración y la gestión urbana (de la ciudad) y los procesos de urbanización, competencias propias del municipio pero que no dejan de ser difíciles cuando el Estado es centralista o cuando los recursos locales económicos, naturales y humanos son escasos o limitados. Estas escalas definen distintos y complementarios procesos de planificación, que, eventualmente, garantizan, no sólo un uso más eficiente del espacio sino también una mejor distribución de los beneficios y costos del planeamiento, así como la participación democrática de las personas en los procesos de desarrollo de su territorio.

La legislación municipal y los marcos normativos en cada país del continente reconocen las competencias de los ayuntamientos, aunque este reconocimiento no es siempre claro cuando se trata de precisar las funciones propias del gobierno local en su ámbito. En la práctica del control del territorio, de sus usos, y de las políticas de planificación, continúan privando las visiones centralistas fragmentadas institucionalmente en toda el área, lo que evidencia la dificultad que tienen los Estados Nación, desde el punto de vista jurídico, no sólo de comprender el espacio como totalidad, sino incluso de gestionar medianamente el territorio, a escala regional o local.

Las leyes de planificación local en un mundo global y la cuestión de las resistencias, o de los mundos alternativos posmodernos hasta ahora lo que han conseguido es banalizar las contradicciones esenciales del mercado, proponiendo el fin de la historia, la importancia del ya y el ahora, el consumismo, la moda y las luchas por todas las diversidades posibles que no han llevado a ninguna transformación estructural o a propuestas políticas alternativas para cambiar una sociedad egoísta y frívola y una economía que produce y acrecienta las desigualdades. Lo que han provocado es el resurgimiento de los demonios del medioevo, la mediocridad política, los nuevos evangelios fundamentalistas y una sociedad embelesada por las mercancías y no se interesa por los seres humanos de carne y hueso que viven el espanto del mercado de armas, drogas, cuerpos y artefactos para cualquier cosa. Así, no sólo se transforma el paisaje urbano, se transforman los valores, las relaciones sociales, las mercancías, el 
valor de las cosas, incluso cuando se habla de diversidad, inclusión y equidad, conceptos que como cualquiera otros son ideológicamente manipulables. Estos son acontecimientos cotidianos con los que hay que combatir en las propuestas de organización para transformar los espacios en procura de la emancipación social política e ideológica de la ciudad y la región.

El desarrollo urbano y de su entorno inmediato, que se plasma espacialmente en los procesos de expansión horizontal y difusa de las ciudades y la incorporación de los espacios rurales a la dinámica urbana implica la protección de ese medio ambiente que va de la ciudad a los espacios libres y que en cada subespacio (zona, o territorio específico) presenta particularidades que deben ser atendidas desde la legislación general y desde la legislación local a través de los planes reguladores cantonales.

Ahora bien, hay aspectos que se destacan en la producción bibliográfica cuando se trata de analizar el espacio como formación jurídico-política para la planificación regional. Estos aspectos son: a) Las contradicciones en la legislación, que se producen básicamente entre las instituciones centralizadas que impulsan la planificación sectorial y los objetivos e intereses específicos de las unidades territoriales básicas a las que se les han asignado constitucionalmente competencias para la gestión del territorio; b) La especificidad del espacio geográfico en cada unidad administrativa que no siempre es comprendida (aprehendida) en las estrategias de planificación cuando se trata de conciliar al Estado nacional con los espacios, regiones o territorios locales (el territorio del cantón o del distrito particular); c) La complejidad de los instrumentos jurídicos, esto afecta principalmente a la gestión del gobierno local, sobre todo cuando una vez aprobado un plan de ordenamiento de su territorio, los responsables de la administración no están familiarizados con el marco normativo; d) El problema del poder y del estilo en la utilización de este. El problema del poder cuestiona, a veces, la legitimidad de su ejercicio, desde dónde debe usarse este poder, es decir, a quién le compete y, finalmente, el problema de cuáles son las formas apropiadas y legítimas de participación ciudadana en la práctica de la democracia.

La literatura específica señala que la función de planificación urbana es de carácter jurídico - política, técnica y administrativa, que se ejerce sobre una unidad territorial, pero muchas veces ignora que esta función no necesariamente responde a las formas específicas de la configuración del espacio (a no ser justamente, desde la perspectiva de cierta "geografía política", 
conocida oficialmente como la División territorial politica administrativa del país), por un lado, y por otro, evidencia los problemas propios de una sociedad en la que el proceso de gestión del territorio casi nunca es realizada científica e integralmente, es decir, con participación de los agentes sociales involucrados.

Tampoco desde el punto de vista del espacio construido socialmente, la planificación responde a los principios de equidad social (o específicamente del uso democrático del espacio), y por ello mismo sin que medie en el proceso de planificación principio alguno de equilibrio territorial o uso racionalmente equilibrado o armónico del paisaje.

De esta manera, las investigaciones indican que el espacio geográfico y la planificación territorial son esencialmente categorías de la totalidad, pero el marco normativo y las instituciones del Estado a través del cual se organizan es de naturaleza positivista. El marco jurídico es expresión de Estados centralistas internamente colonialistas, y sus componentes (las instituciones) y los aparatos ideológicos del poder en concordancia con los instrumentos propios del mercado capitalista, hacen que el territorio tienda a fragmentarse, a desvincular o a desgarrar lo que por naturaleza está integrado, con miras a ser mejor explotado y a "desmembrarlo de manera unificada", en función del ejercicio del poder centralizado. 
Figura 2: América Latina: líneas de investigación dominantes en linvestigaciones sobre ciudad, la cuestión urbano regional, urbanismo, ambiente y territorio

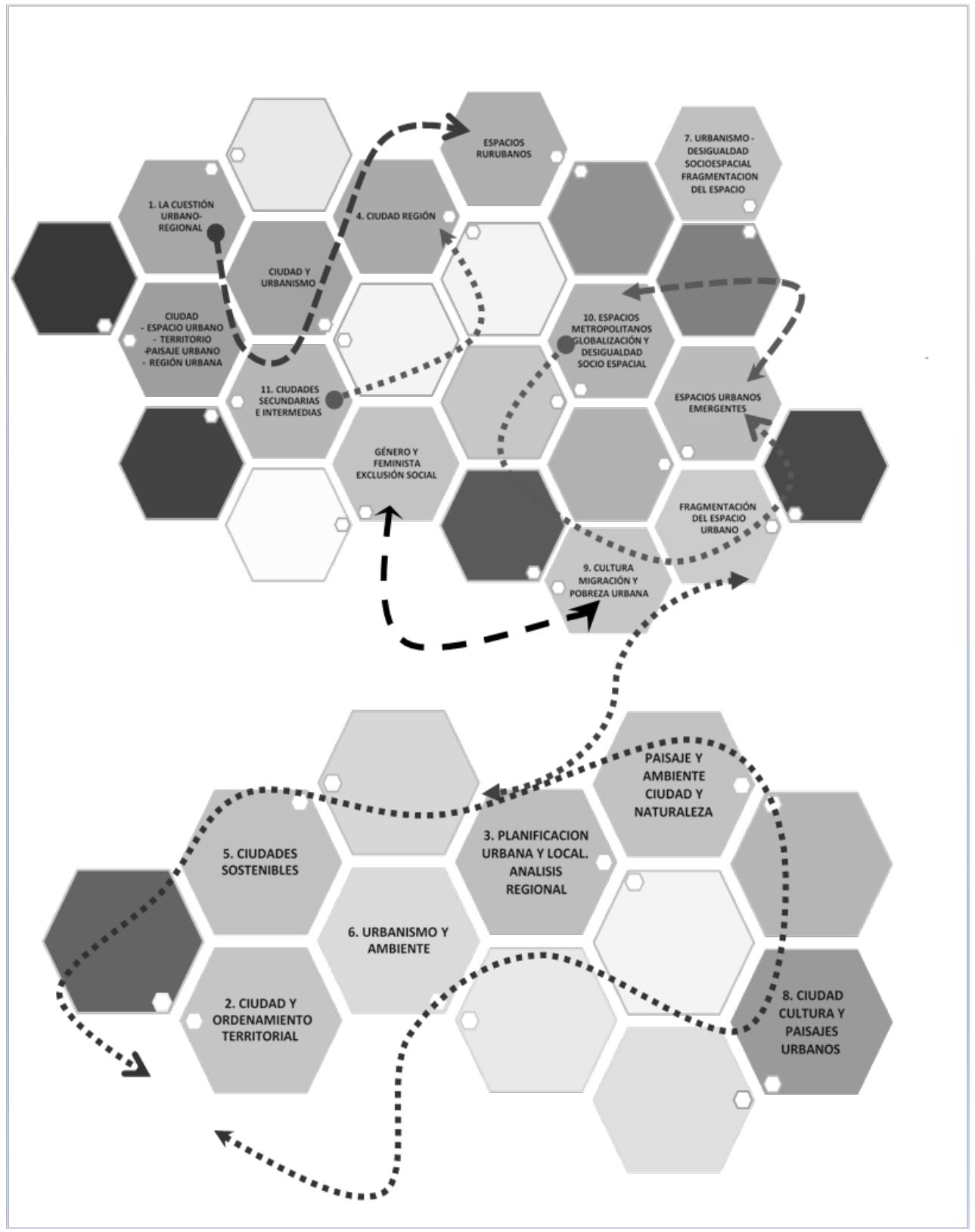




\section{Algunos temas emergentes en América Latina en el análisis de la ciudad y las cuestiones urbano-regionales}

A partir de los noventa, en América Latina se producen trabajos académicos en los que el concepto de espacio relativo se acerca a la idea compleja y dialéctica del espacio como totalidad, en algunos casos, como ya se señaló, son propuestas que conciben un espacio funcional al sistema y en otros casos, análisis historicistas del espacio cultural. En las nuevas geografías culturales, por ejemplo, se trata el tema de lo local, el barrio o la calle y la región geográfica y su relación con la imagen global del territorio, desde las ciencias sociales de tradición ideográfica, recurriendo a las monografías, los estudios de caso, en fin, los estudios cualitativos dentro de la vieja tradición de la antropogeografia cultural o de las nuevas corrientes del giro cultural.

La ciudad como organización compleja permite una variedad de estudios, de enfoques, de propuesta para el análisis, y surgen investigaciones tanto disciplinarias, interdisciplinarias, y transdisciplinarias. Una de las formas de fragmentación que en América Latina ha sido más examinado en los últimos años es el de las ciudades amuralladas antes citado (Dammert, 2004; Guerrin, 2005; Veiga, 2009; entre otros).

Algunos especialistas trabajan con la idea de fragmentación, dentro de una categoría más general, la de segregación espacial o socio -espacial a partir de la arquitectura o de la sociología del espacio (Lungo y Baires, 1998, 2001; Méndez et al., 2006), o desde una renovada ecología urbana (Henríquez, 2005; Barkin, 2011).

La revista Ciudad y territorio: Estudios territoriales, dedicó en el año 2002, dos números a esta cuestión en América Latina y Europa analizando las formas de polarización y exclusión social de los espacios de las grandes metrópolis, que se manifiestan a través de lo que algunos de estos autores llaman las ciudades amuralladas, ciudades cerradas, enclaustradas, etc. que explican las formas actuales (del capitalismo en crisis) del viejo proceso de fragmentación que han sufrido las urbes en el sentido de la separación físico (espacial) y social entre los distintos sectores y clases sociales. Son los no lugares como intersticios en la trama urbana, los espacios opacos de M. Santos, en donde lo global- local emerge como escenario de los ciudadanos del mundo, de los acontecimientos globales que impactan la vida pública y privada, y golpean desigualmente al sujeto individual y colectivo que allí vive. 
En el marco de los estudios recientes, aunque siempre ha habido en el continente pensadores que han estudiado la ciudad como un fenómeno cultural, han proliferado nuevos abordajes que en su mayoría plantean una explicación ecléctica (que va desde la fenomenología y los estudios de la percepción del espacio hasta posiciones posestructuralistas) del paisaje urbano, de la vida cotidiana y de los problemas socio económicos de las minorías (Jouffe, 2010).

\section{Ciudades secundarias e intermedias}

Los factores geográficos que naturales y creados tienen mayor influencia en la distribución espacial de la población y los niveles de ingresos en América Latina recientemente están siendo claves para el desarrollo de las ciudades secundarias e intermedias del continente (Quintero, 2009; Torres y Caicedo, 2015). El interés por conocer lo que ocurre con las pequeñas y medianas ciudades intermedias comienza a tener un impacto sustancial en los institutos de investigación de las Universidades en la Región a partir de la década de los noventa (encuentro de Lleida (España) en marzo-abril de1998). Un ejemplo de estos análisis lo constituyen, entre otros, los estudios de casos específicos de Usach y Garrido (2008) y Valdés (2007) y los ya citados de Quintero (2009) y Torres y Caicedo (2015).

Del concepto ciudad secundaria que parece centrarse en tablas demográficas y aspectos cuantitativos, se pasó al de ciudad intermedia que destaca la función que realizan estas ciudades en el territorio por su vocación de articularse con otros nodos y territorios de la red global. Las ciudades intermedias, al mismo tiempo que son nodos de las redes locales conectadas al sistema regional y nacional y algunas accesibles a las redes internacionales, son núcleos urbanos a escalas y dimensiones humanas, aprehensibles para el ciudadano, con mayor cohesión social y mejores relaciones interpersonales, lo que supone una ciudad con mayor identidad que las grandes metrópolis.

El crecimiento de las ciudades medianas o pequeñas introduce elementos más dinámicos y estratégicos en el espacio geográfico, que incorpora nuevas posibilidades para la autoafirmación, y el reforzamiento de la ciudad-región y su apertura y consolidación a otras escalas.

Investigaciones cuantitativas y cualitativas de las ciudades intermedias en América Latina, ponen de relieve elementos de transversalidad y a la vez de diversidad en cuanto a la elaboración de objetos de estudio en este campo. 
La revisión de la literatura en esta línea de trabajo deja la sensación de que el enfoque es más estructural funcionalista cuando las investigaciones se refieren a las ciudades secundarias (Sánchez, 2017) y mucho más críticos cuando hacen referencia a las ciudades intermedias en los países de la periferia capitalista y los cambios que estas han sufrido en términos de las desigualdades y la fragmentación social, espacial y cultural (Boisier, 2006; Cuervo, 2003; Mancheno y Terán, 2012).

Cómo han cambiado tales influencias a través del tiempo, particularmente en las últimas dos décadas y cuán importantes serán estas influencias en el futuro. A través de qué medios han sido transmitidas estas influencias: ¿̇costos de transporte, economías de escala, de aglomeración, externalidades positivas y negativas, productividad agrícola, condiciones de salud, etc.? ¿El proceso de urbanización y la importancia relativa de las ciudades ha sido afectado por las tendencias recientes hacia la descentralización y la globalización? Si las ciudades secundarias han experimentado un resurgimiento, cuáles son las fuerzas que explican estos patrones de urbanización.

Además, se aborda la cuestión de que en el continente siempre ha habido un fuerte ligamen entre la pobreza rural y el crecimiento demográfico de las metrópolis, de ahí que el tema central en este campo siga siendo responder a interrogantes que buscan explicar de qué manera se produce la relación entre el desarrollo económico, espacios rurales y el crecimiento de las metrópolis. De qué forma se pueden mejorar las condiciones de vida del conjunto de la población de los países del continente a partir del fortalecimiento de las ciudades secundarias. ¿Por qué no ha sido posible el desarrollo regional equilibrado al interior en estos países en tiempos de globalización económica?

Estas son preguntas que siguen estando presentes implícita o explícitamente en las investigaciones sobre este tema en continente.

Las investigaciones sobre los procesos de transformación que sufren estas ciudades intermedias a partir de la globalización económica neoliberal en Centroamérica son aún escasos, pero son numerosos en el resto del continente, sólo para ilustrar mencionaremos a Carmona et al. (2007), entre muchos otros.

\section{Los posmodernismos y los estudios emergentes alternativos}

Los estudios sobre los espacios urbano-regionales, la ciudad y el urbanismo se completan con investigaciones relativas a problemas de equidad social, 
económica y política incorporando en ellas el enfoque de género. En muchas de estas pesquisas hay mayor preocupación por hacer ver que la explicación de tales asuntos se fundamenta en las prácticas sociales intersubjetivas y sus relaciones con el poder y no necesariamente son reflejo de las relaciones sociales sociales de producción, el desarrollo de las fuerzas productivas o infraestructura económica alguna. Por otra parte, hay análisis que recuperan los aportes de los clásicos para la comprensión, en la totalidad construida, de las relaciones objetivas entre estructuras económicas y procesos culturales. Estos últimos, inspirados en algunos textos de Marx, la escuela de Lucaks, los estudios de Gramsci y los aportes sobre el espacio urbano hechos por Henry Lefebvre, entre otros. El debate en esta línea está abierto.

La cuestión de género remite a una visión integral del origen y las causas en la desigual utilización y distribución de los espacios geográficos, y el análisis espacial marca la pauta explicativa de las condiciones económicas, sociales, políticas y culturales "específicas" 7 de la sociedad en su conjunto. Los temas que más preocupan son la violencia de género, la inseguridad y la pobreza, de los cuales son las mujeres y sus familias las victimas principales: contra la violencia sobre las mujeres, los derechos de las mujeres, el miedo de habitar libremente la calle en la sociedad patriarcal. Las investigaciones desde estas "geografías disidentes” comienzan a tener mucha más fuerza a partir de los noventa del siglo pasado e incorporan otros estudios esenciales para la región como el eco feminismo, los trabajos sobre minorías étnicas, emigrantes, y los temas de exclusión social que han adquirido mucha fuerza principalmente en países como México, Brasil, Argentina, Colombia y Chile, sin que esto signifique que en el resto del continente no hayan estudios importantes en estas temáticas, pero quizás con menor divulgación los de los países antes mencionados. Por ejemplo, en Ecuador, Bolivia, Venezuela y Uruguay el desarrollo de investigaciones alternativas desde una "epistemología del sur", son ahora frecuentes dentro de una concepción que integra el análisis social con las cuestiones ecológicas, ambientales y culturales.

En fin, se trata de contribuir desde estos estudios en procura de la igualdad y la equidad, de la inclusión socio cultural, de eliminar las barreras en el uso social del espacio, de promover y comprometerse con la participación política de las mujeres y de dignificar la vida cotidiana de ellas y sus familias,

\footnotetext{
7 El espacio geográfico es totalidad y es también una especificidad.
} 
asuntos esenciales sobre los que se investiga, se escribe y se denuncia cada vez con más frecuencia en América Latina.

\section{Conclusiones provisionales del aprendizaje continental}

De las consultas realizadas obtenemos tres aprendizajes para trabajar en Centroamérica:

Sobre la cuestión teórico-metodológica del abordaje de la cuestión aqui tratada

Desde los estudios urbanos en general definir qué es una ciudad pasa por la cuestión de cómo se delimita hoy la urbe, y conforme crece la tasa mundial de urbanización conceptos como "límite" y "medida", por naturaleza rígidos, son superados por las prácticas sociales que rompen con ellos. El espacio geográfico en general y el urbano en particular, el de la ciudad singular, es fugaz, intermitente, líquido, flexible, percibido, transformado social y culturalmente, es un espacio-con tiempos distintos para las personas, las mercancías, los objetos, la burocracia y el capital.

El cambio tecnológico convierte el medio geográfico en un sistema de redes que convive con las regiones clásicas, con los lugares y con los paisajes. Un sistema complejo, dialéctico, históricamente determinado que ha ido configurando relaciones hacia adentro y hacia afuera de la ciudad. La urbe es una ciudad-región, un subsistema regional dentro de la red global al que se le asignan roles diferentes en el proceso de acumulación flexible. Y en el juego de las identidades locales y globales, se transforman los subsistemas regionales urbanos, los nuevos espacios de lo global y local en donde se generan nuevas subordinaciones y nuevas colonialidades globales surgen.

De esta manera, creemos que las nuevas configuraciones de la ciudad y los espacios regionales y sus tendencias, se constituyen en el marco de referencia para los estudios de las especificidades que presenta el desarrollo del capitalismo actual en esta nueva "geografía regional y local".

\section{Sobre planificación urbana y el ordenamiento del territorio}

A pesar del enorme esfuerzo realizado por las naciones a través de los programas multilaterales para atacar los problemas de gestión pública, la seguridad ciudadana, los cambios en las estructuras productivas nacionales, las dificultades 
en infraestructura, y la brecha tecnológica, ni estos ni los viejos problemas se han resuelto sustantivamente y por el contrario se han agudizado situaciones como el desarrollo urbano desigual y excluyente y otros arriba mencionados. Propuestas como Ciudades del Futuro del Banco de Desarrollo de América Latina, e "Iniciativa de Ciudades Emergentes y Sostenibles” del BID, o el Programa para la Reducción de Riesgos Urbanos con apoyo del BIRF - Banco Mundial y el Programa de las Naciones Unidas para el Desarrollo (PNUD), no han sido tan exitosos cuando los resultados son evaluados por ellos mismos para cada país latinoamericano.

Desde la perspectiva crítica desarrollo urbano no sólo significa clasificación o zonificación de usos del suelo, significa también recuperación de espacios degradados, pero, fundamentalmente, búsqueda de una mejor distribución de la riqueza, participación comunal, concertación, uso y explotación racional de los recursos con que cuenta un territorio al nivel local, y esta configuración del espacio geográfico, está definida, en última instancia, por la formación sociopolítica propia de cada Nación, por el estilo de desarrollo que esta formación socio política ha establecido y por los dictados del mercado global.

\section{Para los estudios de la ciudad y la región en Centroamérica}

En el subcontinente la diversidad de las formaciones socio políticas, ecosistémicas y culturales presentan retos en los estudios geográficos relacionados con migraciones, zonas fronterizas, redes de núcleos urbanos intermedios, formas de apropiación del espacio regional por los capitales transnacionales hegemónicos, participación de las élites de la región en la apropiación de los espacios locales, el cambio climático y su impacto en las economías autóctonas. El futuro de los espacios comunales y las economías alternativas en el contexto del desarrollo regional desigual. La participación de las mujeres en la toma de decisiones y en el desarrollo político y económico de los espacios urbanos y rurales. Estos hasta ahora, han sido temas muy poco estudiados, las investigaciones oficiales, la de algunos organismos de cooperación internacional y las oenegés, se han concentrado prioritariamente en el desarrollo del turismo comunitario y el ecoturismo y en cómo atacar la pobreza o solucionar el déficit de vivienda popular, sin que sean abordados como problemas estructurales que deben ser analizados en el contexto socio político y espacial en el que se producen, aunque existan informes internacionales de prestigio que llaman la atención respecto de estos problemas (BIRF - Banco Mundial, 2016).

He ahí el reto de continuar trabajando estos temas en el medio científico universitario de Centro America. 


\section{Referencias}

ANNICK, G. y POLÈSE, M. “La ecología humana de las ciudades en desarrollo: ensayo de geografía residencial de Puebla, México". Coloquio Internacional. Las ciudades y las regiones urbanas frente a la modernización. Universidad Autónoma de Puebla, Puebla, México, mayo 1994.

BAIRES, S. "División social del espacio urbano y emergencia de los barrios cerrados en el Área Metropolitana de San Salvador”. En Séguin, A. M. (ed.). La segregación socio-espacial urbana: una mirada sobre Puebla, Puerto España, San José y San Salvador. 1 ed. San José, C. R.: FLACSO, 2006, pp. 47-84.

BARKIN, D. "Ecología y Ciudad: problemas y perspectivas" (Panel). Congreso Latinoamericano de Estudios Urbanos, 2015.

BARRERA, A. “Quito, una propuesta de ciudad-región”, Questiones Urbano Regionales, v. 1, n. 1, pp. 39-52, 2012.

BASCUÑAN, F. et al. (2007). "Modelo de cálculo de áreas verdes en planificación desde la densidad habitacional”. Revista Urbano, n. 15, pp. 97-101, 2007.

BEN AMAR, K. y ROSALES, S. Elproyecto de Ordenamiento Territorial de El Salvador: reflexiones globales sobre los avances, limites y posibles debates. San Salvador, El Salvador: Corporación de Municipalidades de la República de El Salvador (COMURES) Agence d' Urbanisme pour le Developpement de l' Agglomeration Lyonnaise, 2005.

BENSÚS, V. y PÉREZ, A. “Nuevas dinámicas territoriales en ciudades intermedias. El caso de Huamachuco, La Libertad”. Cuadernos Arquitecturay Ciudad, n. 20, PUCP, Lima, 2014.

BIRF - Banco Mundial. "Estudio de la Urbanización en Centroamérica. Oportunidades de una Centroamérica urbana”, jun. 2016 Recuperado de: http://documentos. bancomundial.org/curated/es/406571468196193946/pdf/106268-REVISED-SPANISH-PUBLIC-P152713-Central-America-Urbanization-Review-Final-Output-SPANISH-2.pdf.

BLANDÓN, F. (coord.). Plan Nacional de Ordenamiento y Desarrollo Territorial (PNODT): Una lectura desde la Sociedad Civil. San Salvador: FUNDE - CARE, 2005. Recuperado de: http://190.120.10.43/db/libcat/edocs/PNODT_1.pdf 
BOISIER, S. "Algunas reflexiones para aproximarse al concepto de ciudad-región. Estudios Sociales, v. 15, n. 28, pp. 163-90, jul.-dic. 2006.

BUZAI, G. Mapas sociales urbanos. Buenos Aires: Lugar Editorial, 2003.

CABALLERO, E. L. "Planificación del territorio urbano en Honduras: entre la acción pública y de mercado, 2010”. Recuperado de: http://www.geogra.uah.es/ inicio/I_cong_honduras/docs/ponencias_pdf/ponen3_pdf/Ponente-honduras/ Ponencia_Lily_Caballero.pdf.

CAMPOLINA, C. "Repensando la cuestión regional brasileña: tendencias, desafíos y caminos". Revista Eure, v. 29, n. 88, pp. 29-53, 2005.

CAQUIMBO, S. "La calidad del espacio público en la construcción del paisaje urbano. En busca de un hábitat equitativo". Revista invi, v. 23, n. 62, pp. 75-97, 2008. Recuperado de: http://www.revistainvi.uchile.cl/index.php/INVI/article/view/349/938.

CARDOSO, A. G. y Ortiz, J. P. “Periurbanización, segregación social y fragmentación territorial”, 2009. Recuperado de: www.filo.unt.edu.ar/rev/geo/R11_OrtizCardoso_periurbanizacion.pdf.

CARMONA, M. et al. (eds.). Bordes e intersticios urbanos: Impacto de la Globalización. Córdoba, Argentina: Departamento de Gestión y Renovación Urbana. Facultad de Arquitectura y Urbanismo. TU Delft. Holanda-Escuela de Arquitectura Universidad de Valparaíso. Chile-Instituto de Investigación de Vivienda y Hábitat Facultad de Arquitectura, Urbanismo y Diseño. Universidad Nacional de Córdoba. Argentina, 2007.

CASTRO, C. D. "Mega crecimiento urbano de la ciudad de Panamá y su impacto sobre el hábitat y la vivienda popular”. Dimensiones del hábitat popular latinoamericano. Quito, Ecuador: FLACSO, 2012, pp. 75-99.

COLAN, E. et al. "Trama urbana-Distrito de la Molina”. Seminario de urbanismo. Universidad Alas Peruanas, Barranco, Perú, 2013.

CUERVO, L. M. Pensar el territorio: los conceptos de ciudad-globaly región en sus origenes y evolución. Santiago de Chile: ILPES/CEPAL, 2003. 
DAMMERT, L. “¿Ciudad sin ciudadanos? Fragmentación, segregación y temor en Santiago”. Revista Eure, v. 30, n. 91, pp. 87-96, 2004.

DAVIS, D. y DEL CERRO, G. “'Ciudad global', un concepto en transición”. Ciudady territorio: estudios territoriales, n. 159, pp. 31-42, 2009.

DE LA ESPRIELLA, E. “¿Una vivienda social incluyente en Liberia? El caso de una ciudad intermedia de Costa Rica”. Revista INVI, v. 59, n. 22, pp. 69-92, 2007.

DUHAU, E. y GIGLIA, A. "Espacio público y nuevas centralidades. Dimensión local y urbanidad en las colonias populares de la ciudad de México". Papeles de Población, n. 41, pp. 167-94, 2004.

FERNÁNDEZ, V. y LUNGO, M. (comp.). Estructuración de las capitales centroamericanas. San José, C.R.: EDUCA, 1988.

FLORES, R. Y. Globalización y espacio urbano en la ciudad de San Miguel. Documento. Universidad de El Salvador, 2009.

FUNDASAL y PNUD. Escenarios de vida desde la exclusión urbana: una mirada al hábitatpopular de 32 ciudades de El Salvador. San Salvador: FUNDASAL y PNUD, 2009

FUPROVI. Vivienda y Asentamientos en Precario en la GAM. Costa Rica: Estado de La Nación, 2005. Recuperado de:http://fuprovi.org/files/publicaciones/16_19_ES_vivienda_precarios_gam 1987-2004.pdf.

FÜRST, E. Crisis, espacio y aprendizaje social: la cuestión regional en el capitalismo global. Heredia, C.R.: EUNA, 2013.

GARZA. G. y SCHTEINGART, M. (coord.). Desarrollo urbano y regional: Los grandes problemas de México. México, D.F.: El Colegio de México, 2010.

GERMAIN, A. y POLÈSE, M. "La ecología humana de Puebla: ensayo de geografía residencial”. En PÉREZ, S. y POLÈSE, M. (comp.). Modelos de análisisy planeación urbana: estudios sobre la evolución y tendencias de la ciudad de Puebla. México: Plaza y Valdés Ed., 1996, pp. 63-88.

GONZÁLES, G. y SERRANO, J. La planificación urbana y su impacto en la calidad de vida en Santa Cruz de la Sierra. Santa Cruz: PIEB/Cedure/Jatupeando, 2014. 
GUERRIEN, M. "Arquitectura de la inseguridad, percepción del crimen y fragmentación del espacio urbano en la zona metropolitana del Valle de México", 2005. Recuperado de http://halshs.archivesouvertes.fr/docs/00/05/40/63/PDF/Arquitectura_de_la_inseguridad.pdf.

HENRÍQUEZ, C. "Nuevas perspectivas en ecología urbana”. En FUNDACIÓN CEPA (ed.). REIMONDI, I. (coord.). La sustentabilidad hoy. La Plata, Buenos Aires: Fondo editorial CEPA, 2005, pp. 85-98.

IREGUI, J. “Derivas por Bogotá -Proyecto observaciones". Centro de Competencia en Comunicación para América Latina, 2005. www.c3fes.net.

JOUFFE, Y. "Contra el derecho a la ciudad accesible. Perversidad de una reivindicación consensual”. En SUGRANYES, A. y MATHIVET, C. Ciudadespara tod@sPor el derecho a la ciudad, propuestas y experiencias. Santiago de Chile: Hábitat International Coalition (HIC), 2010, pp. 45-58.

LIDTH, M. y SCHÜTTE, O. “GAM(ismo): Cultura y Desarrollo Urbano en la Gran Área Metropolitana de Costa Rica”. Cuaderno de Ciencias Sociales, n. 155, Facultad Latinoamericana de Ciencias Sociales (FLACSO), 2010. Recuperado de: http:// www.flacso.or.cr/fileadmin/documentos/2010/Cuaderno_155.PDF.

LUNGO, M. y BAIRES, S. Hábitat popular urbano y riesgos ambientales: estudio de cuatro comunidades precarias del Area Metropolitana de San Salvador. Cochabamba: IIA-LCHS (PROMESHA), 1998.

y - "Socio spatial segregation and urban land regulation in Latin American cities". Segregation in the city, Lincoln Institute of Land Policy (LILP), Cambridge, Massachusetts, del 25 al 28 de Julio, 2001.

MANCHENO, D. y TERÁN, J. F. “La ciudad-región en América Latina: Un concepto entre el neoliberalismo y el posliberalismo". Revista del Instituto de la Ciudad, v. 1, n. 1, pp. 139-52, 2012.

METZGER, P. et al. (ed.). La cuestión urbana en la región andina: miradas sobre la investigación y la formación. Quito: Pontificia Universidad Católica del Ecuador, Centro de Publicaciones, 2016. 
MONTOYA, J. W. Cambio urbano y evolución discursiva en el análisis de la ciudad Latinoamericana: de la dependencia a la globalización. Bogotá: Universidad Nacional de Colombia. Facultad de Ciencias Humanas, 2006.

- "Globalización, dependencia y urbanización: la transformación creciente de la red de ciudades de América Latina”. Revista de Geografia Norte Grande, n. 44, pp. 5-27, 2009.

MORÁN, A. Las ciudades intermedias en Guatemala. Guatemala: Universidad de San Carlos de Guatemala. Centro de Estudios Urbanos y Regionales, 2007. Recuperado de http://ceur.usac.edu.gt/pdf/2007/Amanda_Moran_2007.pdf.

. Las ciudades intermedias y el desarrollo regional en Guatemala. Ciudad de Guatemala: Universidad de San Carlos de Guatemala, Centro de Estudios Urbanos y Regionales, 2011a.

- Segregación, vulnerabilidad y exclusión social en la ciudad. Una versión de los asentamientos precarios. Ciudad de Guatemala: Universidad de San Carlos de Guatemala, Centro de Estudios Urbanos y Regionales, 2011 b.

ONU-HÁBITAT. Estado de las Ciudades de América Latina y el Caribe 2012. Recuperado dehttp://www.onuhabitat.org/index.php?option=com_docman\&task=doc_vi ew\&gid $=816 \& \mathrm{tmpl}=$ component $\&$ format $=$ raw $\&$ Itemid $=18$

PÉREZ, M. "Los impactos perversos de la segregación socio-espacial en la ciudad de San José". En Séguin, A., (ed.). La Segregación socio-espacial urbana: una mirada sobre Puebla, Puerto España, San Joséy San Salvador (pp. 147-178). San José, C.R.: FLACSO, 2006.

QUINTERO, O. F. "Ciudad-región” y el proyecto regional una mirada sobre la reconfiguración territorial en Colombia (tesis de maestría). Pontificia Universidad Javeriana, Bogotá D.C., Colombia. Recuperado de https://repository.javeriana.edu.co/ handle/10554/209.

RIONDA, J. "Pensar la ciudad desde la óptica del territorio". Revista URBANO, n. 17, pp. 76-82, 2008.

RIVERA, A. y Jáuregui, S. El mercado inmobiliario en La Paz, Cochabamba y Santa Cruz. Cochabamba: CERES, 2013. 
ROBERT, J. (2015). Seminario Regional. "La cuestión urbana en América Latina: panorama y desafíos de la investigación y la formación”. Bulletin de l'Institut français d'études andines, v. 44, n.3, 2015. http://bifea.revues.org/7738. DOI: 10.4000/ bifea.7738.

ROBINSON, W. I. Una teoría sobre el capitalismo global. Bogotá, Colombia: Ediciones desde abajo, 2007.

RODRÍGUEZ, G. et al. Vivir divididos: fragmentación urbana y segmentación social en Cochabamba. Cochabamba: Gobierno Municipal de Cochabamba.

RODRÍGUEZ, L. "La red de ciudades globales y la fragmentación social en Buenos Aires”. Temas, n. 48, pp. 56-65, 2006. Recuperado de: www.temas.cult.cu/revistas/48/07_Lucia.pdf

RUIZ, A. H. "Desigualdad territorial y fragmentación urbana en Zapopán, México". Revista Lider, v. 15, n. 11, pp. 209-34, 2009.

SÁNCHEZ, L. "Tendencias de crecimiento en ciudades intermedias. El caso de San Isidro de El General, Ciudad Quesada y Guápiles" (informe técnico). San José, Costa Rica: Informe Estado de la Nación en Desarrollo Humano Sostenible, 2017.

SÉGUIN, A. (ed.). La segregación socio-espacial urbana: una mirada sobre Puebla, Puerto España, San Joséy San Salvador. San José, C. R.: FLACSO, 2006.

SERRANO, M. Habitar y transitar la ciudad: percepciones y experiencias de los niños y niñas sobre la ciudad de La Paz. Buenos Aires: Clacso, 2015. (Serie Documentos de Trabajo Red de Posgrados 51).

TORRES, P. y CAICEDO, C. J. "Las ciudades intermedias con mayor potencial en Colombia. Un sistema de identificación. (Nota técnica del BID; IDB-TN-758).” Recuperado de: https://publications.iadb.org/bitstream/handle/11319/6890/ Las_ciudades_intermedias_con_mayor_potencial_Colombia.pdf ?sequence $=1$

TOUDERT, D. y BUZAI, G. D. Cibergeografia: tecnologias de la información y las comunicaciones (TIC) en las nuevas visiones espaciales. Mexicali, Baja California: Ediciones de la Universidad Autónoma de Baja California, 2004. 
USACH, N. y GARRIDO, R. Globalización y ciudades en América Latina. ¿Es el turno de las ciudades intermedias en la Argentina? Madrid: Instituto Universitario de Análisis Económico y Social (IAES) -Universidad de Alcalá. (Serie Documentos de Trabajo, 10), 2008. Recuperado de: http://www.iaes.es/iuaes sp/publicaciones.htm.

VALDÉS, E. "Fragmentación y segregación urbana. Aportes teóricos para el análisis de casos en la ciudad de Córdoba”, 2007. Recuperado de: www.ffyh.unc.edu.ar/alfilo/ alfilo18/pdf/valdes.pdfhttp://bibliotecavirtual.clacso.org.ar/ar/libros/campus/ poggiese/07veiga.pdf

VEIGA, D. (2009). "Desigualdades sociales y fragmentación territorial en el área metropolitana de Montevideo”. Revista Lider, v. 15, n. 11 ), pp. 127-53. Recuperado dehttp://ceder.ulagos.cl/lider/media/numero15/Desigualdades\%20sociales\%20 y\%20fragmentacion\%20territorial.pdf 


\section{Anexo}

\section{Tabla 2: Ubicación de algunas instituciones relacionadas con estudios urbano- -regionales en varios países Latinoamericanos que fueron consultadas para este estudio.}

Instituto Nicaragüense de Estudios Territoriales. Prevención de riesgos, vulnerabilidad, y desarrollo socioeconómico.

Proyecto de Investigación en Desarrollo Urbano Sostenible. Crecimiento urbano, planificación territorial e impacto ambiental.

Programa de Investigación Arquitectura y Gestión Urbana. Desarrollo de asentamientos urbanos y gestión local.

Colegio Federado de Ingenieros y de Arquitectos de Costa Rica. Ingeniería Civil, Arquitectura, Urbanismo.

Programa Salvadoreño de Investigación sobre Desarrollo y Medio Ambiente (PRISMA). Generar conocimiento que fortalezca los medios de vida e innovar en estrategias de desarrollo para una gobernanza incluyente, equitativa y sustentable en Centroamérica.

Centro de Información Urbano Regional del Colegio de

Arquitectos de Honduras (CIUR). Conformación de estudios urbanos como base para un Plan de Ordenamiento Municipal.

Centro Estudios Urbanos y Regionales (CEUR). Investigación y extensión universitaria, para abordar la problemática urbana y regional de Guatemala, Centro América y América Latina.
Frente a Hospital Solidaridad. Apdo. Postal 2110 Managua, NICARAGUA.

Escuela de Ingeniería Civil, Universidad de Costa Rica. San José, COSTA RICA produs@ucr.ac.cr

Escuela de Arquitectura, Universidad de Costa Rica. San José, COSTA RICA

San José, COSTA RICA

Pasaje Sagrado Corazón, No. 821. Colonia Escalón, San Salvador, EL SALVADOR.

prisma@prisma.org.sv

Col. Lomas del Guijarro Sur, al lado del Instituto Salesiano San Miguel, Tegucigalpa, HONDURAS.

CEUR/USAC, Edificio S-11, 3er nivel, Avenida Petapa y 32 calle, zona 12. GUATEMALA 
Programa Universitario de Estudios Metropolitanos. Procesos y fenómenos territoriales

Programa Universitario de Estudios sobre la Ciudad. Planeación y evaluación de las políticas urbanas y territoriales sobre la ciudad.

Centro de Estudios Demográficos, Urbanos y Ambientales (CEED). Investigación y docencia en estudios relacionados con población urbanización en México y América Latina.

Instituto de Estudios Urbanos y Territoriales. Organización y gestión local territorial (urbano, regional y local).

Revista Eure- Instituto de Estudios Urbanos y Territoriales. Santiago de Chile. Organización y gestión local territorial (urbano, regional y local).

Organización Latinoamericana y del Caribe de Centros Históricos. Renovación e innovación del patrimonio de los centros urbanos de la región rescatando las expresiones culturales propias del territorio Latinoamericano y del Caribe. Ciencias y tecnología, políticas sociales; y cultura, suelo urbano.

Facultad Latinoamericana de Ciencias Sociales FLACSOEcuador. Programa de Investigación en Estudios Urbanos. Maestría en Estudios Urbanos

Instituto de la Ciudad. Estudia la ciudad tanto en su dinámica interna, como en su interacción con el sistema urbano nacional e internacional.
Universidad Autónoma

Metropolitana

MÉXICO

Universidad Nacional Autónoma de México. MÉXICO

puec@unam.mx

Camino al Ajusco 20, Pedregal

de Santa Teresa, Tlalpan, 10740

Ciudad de México, Distrito

Federal, MÉXICO

sgiorguli@colmex.mx

Facultad de Arquitectura, diseño y estudios urbano, Pontificia Universidad Católica de Chile, CHILE

ieu@uc.cl

Revista Eure-. El Comendador 1916, Santiago de Chile. Casilla 16002, Correo 9, Providencia, Santiago de Chile. Código Postal: 7530091

Calle del Quinde N45-72 intersección calle de las Golondrinas - Barrio Campo Alegre. Quito, ECUADOR. olacchi@olacchi.org

Quito. ECUADOR

Venezuela 976 y Mejía Esquina, Quito, ECUADOR. 
Instituto de Geografía y Conservación de los Recursos Naturales. Estudia procesos, estructuras y patrones que conforman el espacio geográfico venezolano, con el propósito de prevenir y corregir problemas espaciales y fortalecer las potencialidades geográficas del país.

Revista Geográfica Venezolana. Publica investigaciones en todos los aspectos de la ciencia geográfica y campos afines

Instituto de Investigaciones Gino Germani. Desarrolla la producción científica de la Universidad de Buenos Aires en temáticas como estudios urbanos, migraciones, género, entre otros.

Instituto de Investigaciones y Políticas del Ambiente Construido. Arquitectura, urbanismo, energía, transporte, sustentabilidad y sociología urbana.

Instituto de Estudios del Hábitat. Investigación en el campo del hábitat.

Revista Hábitat. Sustentabilidad, conservación y restauración.

Instituto de Investigaciones y Políticas del Ambiente Construido. Arquitectura, urbanismo, energía, transporte, sustentabilidad y sociología urbana.

Instituto de Estudios Metropolitanos y Regionales. Fenómenos sociales asociados a transformaciones urbanas y regionales.

Instituto de Estudios Urbanos. Universidad Nacional de Colombia. Dinámica y política urbana y regional.
Universidad de Los Andes, Mérida, VENEZUELA.

Instituto de Geografía y Conservación de los Recursos Naturales Mérida, VENEZUELA regeoven@ula.ve

Pte. J. E. Uriburu 950, 6to (C1114AAD) Ciudad Autónoma de Buenos Aires. ARGENTINA iigg@sociales.uba.ar

Facultad de Arquitectura y Urbanismo. Universidad Nacional de La Plata, ARGENTINA. iipac@fau.unlp.edu.ar

Facultad de Arquitectura y Urbanismo. Universidad Nacional de La Plata, Argentina. idehab@yahoo.com

\section{Buenos Aires, ARGENTINA} prensa@revistahabitat.com

Facultad de Arquitectura y Urbanismo. Universidad Nacional de La Plata.

ARGENTINA iipac@fau.unlp.edu.ar

Universidad Pontificia Bolivariana. COLOMBIA

dianac.alvarez@upb.edu.co

Unidad Camilo Torres, Calle 44 no. 45-67. Bloque $\mathrm{C}$, módulo 6. Oficina 901. Bogotá D.C., COLOMBIA comunieu_bog@unal.edu.co 
Centro de Estudios Urbanos (CEUS). Creación de conocimiento para colaborar con el mejoramiento de las condiciones de vida en asentamientos urbanos de países en desarrollo.

Revista Territorios- (CEUS). Creación de conocimiento para colaborar con el mejoramiento de las condiciones de vida en asentamientos urbanos ...

Revista NODO. Se basa en tres ejes: Arquitectura, Ciudad y Urbanismo.

Observatorio de Arquitectura y Urbanismo Contemporáneo. Planeación urbano-regional, arquitectura contemporánea y diseño urbano y paisajismo contemporáneo.

Centro de Estudios Urbanos y Ambientales (URBAM)Trabaja sobre tres ejes principales: medio ambiente, sociedad y urbanismo.

Centro Interdisciplinario de Estudios Regionales (CIDER). Es un centro interdisciplinario de investigación sobre desarrollo a nivel local, regional, nacional y global.
Universidad del Rosario. Facultad de Ciencia Política y Gobierno. Calle 12C \# 6-25, Bogotá, COLOMBIA.

ceus@urosario.edu.co

Universidad del Rosario. Facultad de Ciencia Política y Gobierno. Calle 12C \# 6-25, Bogotá, COLOMBIA. revistaterritorios@gmail.com

Universidad Antonio Nariño. Calle 58 A No. 37 - 94 Bogotá, COLOMBIA.

Escuela de Arquitectura. Universidad del Valle. Edificio 380 - Oficina 5001, Cali, Colombia. fai-arq@univalle.edu.co

Universidad EAFIT. Carrera $49 \mathrm{~N}^{\circ} 7$ Sur - 50. Medellín, COLOMBIA.

contacto@eafit.edu.co

Universidad de los Andes. Bogotá. COLOMBIA. 


\section{Sobre os autores}

\section{Augusto Cesar Pinheiro da Silva}

acpinheiro08@gmail.com

Profesor y geógrafo. Bachillerato y Licenciatura en Geografía (19861990), Maestria en Geografía (Ciencias Sociales, 1993-1996) y Doctorado en Geografía (1998-2005) con énfasis en Geografia Agraria en el Departamento de Geografía de la Universidad Federal de Río de Janeiro. Actua en actividades docentes desde 2000 en el Depto de Geografía de la Pontificia Universidad Catolica de Río de Janeiro (PUC-Rio) en los temas de formación de profesorado y bachillerato en geografía. Es desde 2007 Profesor del curso de Maestria y Doctorado de la PUC-Rio en temáticas de Geografia Humana, temas regionales de Brasil, del estado y de la ciudad de Río de Janeiro así como en los temas de gobernanzas cooperativas y gestión del territorio en Brasil. Es investigador CNPq Nível 2 y Vice Decano de Grado y Postgrado en el Centro de Ciencias Sociales de la PUC-Río desde 2015. Coordina el grupo de investigación 'Gestión Territorial en el Estado de Río de Janeiro (GeTERJ). Ha realizado el Postdoctorado en los temas de Políticas publicas en España para la enseñanza basica en la Facultat de Formación de Profesorado y Educación de la Universidad Autónoma de Madrid (2009-2010). Orienta maestros y doctorandos en Geografía, y participa en conferencias, eventos internacionales y nacionales, así como publica en periódicos indexados pela CAPES-Brasil.

\section{Elton Simões Gonçalves}

elton.goncalves@ifrj.edu.br

Professor. Bacharelado e licenciatura em Geografia na Universidade Federal do Rio de Janeiro (UFRJ), com concentração em Geografia Regional e Agrária. Especialista em Educação Básica - modalidade Ensino de Geografia, Faculdade de Formação de Professores (FFP), vinculada à Universidade do Estado do Rio de Janeiro (UERJ). Mestre em Geografia na Universidade Federal do Rio de Janeiro, com ênfase em Geotecnologias e geografia Agrária. 
Doutorando em Geografia, Pontifícia Universidade Católica do Rio de Janeiro (PUC-Rio). Desde 2009 desempenha atividade docente no Instituto Federal de Educação, Ciência e Tecnologia do Rio de Janeiro (IFRJ). A partir de 2014, também assumiu o cargo docente na Fundação de Apoio à Escola Técnica (FAETEC). Pela Fundação Centro de Educação a Distância do Estado do Rio de Janeiro (CECIERJ), atuou, de 2011 a 2014, na elaboração de material didático para cursos de formação continuada direcionados a docentes da Secretaria de Estado de Educação, (SEEDUC). Desde o ano 2015 faz parte da equipe do Núcleo de Estudos de Geografia Fluminense. Atualmente investiga a emergência de novas ruralidades e quadros paisagísticos à luz da expansão de unidades de conservação privadas no estado do Rio de Janeiro, as Reservas Particulares do Patrimônio Natural (RPPN).

\section{Glaucio José Marafon Professor Associado IGEOG/UERJ glauciomarafon@hotmail.com}

Possui Graduação em Geografia pela Universidade de Passo Fundo (1983), Mestrado em Geografia pela Universidade Estadual Paulista Júlio de Mesquita Filho - Rio Claro (1988), Doutorado em Geografia pela Universidade Federal do Rio de Janeiro (1998), e Pós-doutorado pela Universidade Federal de Uberlândia (UFU) (2010). Atualmente é professor associado do Departamento de Geografia Humana do Instituto de Geografia da Universidade do Estado do Rio de Janeiro. Apresenta publicações que versam sobre Geografia Humana, com destaque para a Geografia Fluminense, com destaque para a séria Revistando o território Fluminense vol. 1 a 6, com orientações na graduação e pós-graduação em temas como relação campo $\mathrm{x}$ cidade, geografia fluminense, transformações no espaço rural, urbanidades e ruralidades, metropolização do espaço e agricultura urbana. Membro de conselhos de diversas revistas científicas de Geografia. Editor da Revista Geo UERJ. Bolsista de produtividade em pesquisa CNPq. Cientista do Nosso Estado / FAPERJ. Editor Executivo EDUERJ. Coordenador de programas profissionais Geografia - CAPES 


\section{Iliana Araya Ramírez}

iliana.araya.ramirez@una.cr

Costarricense, Máster en Planificación Curricular de la Universidad de Costa Rica, Licenciada en Geografía Humana de la Universidad Nacional, y doctoranda en Ciencias Sociales de la Universidad Nacional. Catedrática. Profesora de Geografía en la Universidad Nacional, desde 1993. Coordinadora de la Comisión de Acreditación de la carrera de bachillerato y licenciatura en Ciencias Geográfica con énfasis en Ordenamiento del Territorio, desde 2005. Ha publicado diversos artículos en el campo de la Geografía: la enseñanza, la formación profesional del geógrafo, geografías subjetivas, migraciones y turismo.

\section{Lidia Orias Arguedas \\ lidiaorias@gmail.com}

Académica en la Universidad Nacional de Costa Rica. Cuenta con una licenciatura en Geografía de la Universidad Nacional y una maestría en Geología (Gestión Integral para el Desarrollo de los Georecursos) de la Universidad de Costa Rica. Labora en el Programa para Gestión y el Ordenamiento Territorial (PROGOT) de la Escuela de Ciencias Geográficas, con experiencia en investigación y dirección en elaboración de planes reguladores. Imparte los cursos de Geografía de la población y Geografía de los Transportes.

\section{Lilliam Quirós Arias \\ lquiros@una.cr}

Catedrática. Bachillerato y la Licenciatura en la Escuela de Ciencias Geográficas con concentración en Geografía Humana en la Universidad Nacional de Costa Rica, Maestría en Desarrollo Rural en la Universidad Nacional, Escuela de Agronomía. Desde 1990 desempeña en actividades docentes e investigativas en la Escuela de Ciencias Geográficas de la Universidad Nacional. Ha tenido bajo su responsabilidad cursos Talleres de Investigación, Formulación y Evaluación de Proyectos, y Geografía Rural. Directora y editora de la Revista Geográfica de América Central. Desde el año 2005 forma parte 
del equipo de Acreditación de la Carrera de Ciencias Geográficas con énfasis en Ordenamiento del Territorio. Subdirectora de la Escuela de Ciencias Geográficas en el período 2008-2013 y Directora período 2013-2018. Ha realizado múltiples cursos de especialización profesional y de formación pedagógica, y así como coorganizadora y participante en conferencias, foros, talleres de ámbito nacional e internacional en calidad de ponente. Cuenta con publicaciones académicas en colaboración con académicos de otras universidades de gran prestigio.

\section{Meylin Alvarado Sánchez \\ malvara@una.cr}

Geógrafa de la Escuela de Ciencias Geográficas de la Universidad Nacional de Costa Rica, con bachillerato en Geografía con Concentración en Manejo Territorial de los Recursos Naturales y del Ambiente, licenciada en Educación Ambiental de la Escuela de Ciencias Ambientales y Master en Desarrollo Comunitario Sustentable de la Universidad Nacional de Costa Rica (UNA), con una especialidad en Geografía y Turismo, del Centro Panamericano de Estudios Geográficos (CEPEIGE) del IPGH, OEA en Quito Ecuador. Es evaluadora certificada de la Norma Certificado de Sostenibilidad Turística (CST) del Instituto Costarricense de Turismo. Actualmente es Doctoranda del Programa de Postgraduación en Geografía (PPGEO) de la Universidad Estadual de Río de Janeiro (UERJ) Brasil. Académica de la Escuela de Ciencias Geográficas de la Universidad Nacional desde el 2004. Donde coordina proyectos de investigación y extensión universitaria, en temas de Turismo Rural Comunitario y Sostenibilidad Turística. Imparte cursos a nivel de Bachillerato Universitario en temas de introducción de la Geografía, Geografía Turística, Geografía Rural y a Nivel de maestría imparte el curso de Turismo Rural. Tiene publicaciones en revistas nacionales e internacionales en temas de Educación Ambiental, Humedales, Sostenibilidad Turística, Turismo Rural Comunitario y Cartografía Participativa. Ha participado en cursos, congresos y pasantías a nivel nacional e internacionales en Geografía, Geografía Rural, Turismo Rural y desarrollo comunitario. Forma parte de la Red para el Liderazgo de los exbecarios de la Fundación Kellogg Fellows, para América Latina y el Caribe (KFLA). 


\section{Miguel Angelo Ribeiro \\ mamikisi@gmail.com}

O Pesquisador graduou-se em Geografia pela Universidade Federal Fluminense (1971), concluiu o Mestrado em Geografia pela Universidade Federal do Rio de Janeiro (1982) e Doutorado em Geografia pela Universidade Federal do Rio de Janeiro (1998). Atualmente exerce o cargo de Professor Associado da Universidade do Estado do Rio de Janeiro, tendo experiência na área de Geografia Humana, atuando principalmente com o Estado do Rio de Janeiro, focando nas temáticas do Turismo Urbano e Rural, na rede de localidades centrais, na regionalização e na organização espacial. Atua também em pesquisas voltadas para atividade da prostituição na cidade do Rio de Janeiro.

\section{Mônica Sampaio Machado}

monica.sampaio@pq.cnpq.br

Doutora em Geografia pela Universidade de São Paulo. Professora Associada do Programa de Pós-Graduação e do Departamento de Geografia da Universidade do Estado do Rio de Janeiro. Bolsista Produtividade em Pesquisa CNPq.

\section{Nathan da Silva Nunes \\ nunesuerj@gmail.com}

Bacharel e Licenciado em Geografia pelo Instituto de Geografia da Universidade do Estado do Rio de Janeiro. Mestre em Geografia pelo Programa de Pós-Graduação em Geografia (PPGEO) do Instituto de Geografia da Universidade do Estado do Rio de Janeiro, com a dissertação intitulada Imagem e representações nos cartões postais: a paisagem dos municípios de Armação dos Búzios, Casimiro de Abreu e Saquarema, na região das Baixadas Litorâneas. Doutorando em Geografia pelo Programa de Pós-Graduação em Geografia (PPGEO) do Instituto de Geografia da Universidade do Estado do Rio de Janeiro. Concentração em Geografia, com especialidade nas temáticas 
do Turismo, Imagem, Representações e Paisagem. Tem artigos publicados em periódicos nacionais.

\section{Omar Arrieta Chavarría \\ omar.arrieta.chavarria@una.cr}

Catedrático con más de treinta años como académico de las universidades públicas de Costa Rica. Tiene una Licenciatura en Geografía Humana de la Universidad de Costa Rica y una maestría en "Desarrollo Internacional y Cambio Social” de la Universidad de Clark, Massachusetts. En los últimos años se ha dedicado a los estudios de la ecología política del paisaje, la geografía urbana y la planificación y el ordenamiento territorial. Es doctor por la Facultad de Ciencias Sociales de la Universidad Nacional de Costa Rica.

\section{Pablo Miranda Álvarez \\ pmiranda@una.cr}

Geógrafo graduado de la Universidad Nacional de Costa Rica (UNA), con bachillerato en Geografía con Concentración en Manejo Territorial de los Recursos Naturales y del Ambiente, licenciado en Ciencias Geográficas con Énfasis en Ordenamiento del Territorio y Master en Gestión del Turismo de Naturaleza de la UNA. Docente en la Escuela de Ciencias Geográficas de la Universidad Nacional desde el año 2000. Coordinador del Programa de Estudios Turísticos Territoriales (PETT) UNA, desde el año 2006, Profesor de cursos relacionados con la temática espacial y ambiental de la UNA, así como en universidades extranjeras con el curso Turismo y áreas protegidas en Costa Rica, en la Universidad de Cantabria, España y Diseño de Nuevos Productos y Marketing en el Turismo de Naturaleza en la Universidad Popular de la Chontalpa, Tabasco, México y Diseño de productos turísticos en la Maestría en Turismo y Desarrollo de la Universidad Nacional Autónoma de Nicaragua - León. Ha realizado investigación que incluye proyectos de ordenamiento territorial, Implementación de buenas prácticas de sostenibilidad comunidades rurales de Costa Rica. Ha participado en consultorías nacionales e internacionales como: Planes Reguladores. Ha participado en ponencias nacionales e internacionales relacionadas con el tema así como la realización 
de pasantías a nivel internacional y es evaluador certificado de la Norma Certificado de Sostenibilidad Turística (CST) del Instituto Costarricense de Turismo. Actualmente es Doctorando en Geografía, del Instituto de Geografía de la Universidad Nacional Autónoma de México (UNAM)

\section{Patrícia Francisca de Matos}

patriciafmatos@yahoo.com.br

Graduada em Geografia pela Universidade Federal de Goiás (2001), Mestre em Geografia pela Universidade Federal de Uberlândia (2005), Doutora pela Universidade Federal de Uberlândia (2011), e Pós doutoranda na Universidade Estadual do Rio de Janeiro. Professora no Curso de Geografia e no Programa de Pós Graduação em Geografia da Universidade Federal de Goiás/ Regional Catalão e professora do Programa de Pós Graduação em Geografia da Faculdade de Ciências Integradas da Universidade Federal de Uberlândia. Atua, em ensino, pesquisa e extensão, principalmente nos seguintes temas, relação campo-cidade, agronegócio, educação no campo, agroecologia e movimentos sociais. Coordenadora do Grupo de pesquisa trabalho e movimentos sociais (GETEM).

\section{Thiago Adriano Machado machado.ta@gmail.com}

Mestre em Geografia pela Universidade Federal Fluminense, com interesse nas áreas de História do Pensamento Geográfico e Geografia Econômica, atuando na relação entre a Geografia e o Pensamento Social Brasileiro. Foi investigador visitante no Centro de Estudos Geográficos da Universidade de Lisboa por meio de bolsa CAPES/FCT. É doutorando em Geografia pela Universidade Federal Fluminense, desenvolvendo a tese sobre a interpretação geográfica do Brasil em Milton Santos. 


\section{Valéria Maria de Souza Lima \\ vmslima@gmail.com}

Doutoranda em Geografia pela Universidade do Estado do Rio de Janeiro - UERJ, Mestre em Educação pela Pontifícia Universidade Católica - PUC-Rio, especialista em Administração Pública pela Universidade do Estado do Rio de Janeiro - UERJ, especialista em Turismo pela Universidade Católica de Brasília - UCB, especialista em Teoria e Prática da Educação de Ensino Superior pela Escola Superior de Propaganda e Marketing - ESPM, Administradora pela Universidade Federal Fluminense - UFF. Experiência profissional nas áreas de planejamento e gestão. Docência em Administração e Turismo. Diretora de Planejamento e Projetos da Companhia de Turismo do Estado do Rio de Janeiro - TurisRio de 2004 a 2011. Diretora da Secretaria de Turismo do Estado do Rio de Janeiro desde 2015, atualmente na área de Gestão e Desenvolvimento. Gerente de Turismo da Unidade de Execução do PRODETUR Nacional - Rio de Janeiro, desde 2008. Professora da Escola Superior de Propaganda e Marketing - ESPM em programas de Graduação, Pós Gradução e In Company desde 2000. 